UNIVERSIDADE DE SÃO PAULO - USP

FACULDADE DE DIREITO

PROGRAMA DE PÓS-GRADUÇÃO STRICTO SENSU

CAMILO JOSÉ D'ÁVILA COUTO

Dinamização do ônus da prova: teoria e prática 
Dinamização do ônus da prova: teoria e prática

Tese apresentada ao Programa de Pósgraduação Stricto Sensu da Faculdade de Direito da Universidade de São Paulo - USP, como requisito para obtenção do título de Doutor em Direito.

Área de concentração: Direito Processual.

Orientador: Professor Doutor José Rogério Cruz e Tucci. 


\section{Dinamização do ônus da prova: teoria e prática}

Tese apresentada ao Programa de Pós-graduação Stricto Sensu da Faculdade de Direito da Universidade de São Paulo - USP, como requisito para obtenção do título de Doutor em Direito. Área de concentração: Direito Processual.

Aprovado em:

\section{Banca Examinadora}

Prof. Dr. José Rogério Cruz e Tucci Instituição: Universidade de São Paulo - USP

Orientador

Julgamento: Assinatura:

Prof. Dr. Instituição:

Julgamento: Assinatura:

Prof. Dr. Instituição:

Julgamento: Assinatura:

Prof. Dr. Instituição:

Julgamento: Assinatura:

Prof. Dr. Instituição: Assinatura: 
A Paula, minha esposa, com amor, admiração e gratidão por sua compreensão, carinho, presença e incansável apoio ao longo de todo o período de elaboração deste trabalho.

A Isabela, minha filha, fonte inesgotável de alegria, de amor, de vida.

A Maria da Penha, minha querida mãe, que me trouxe à vida e me deu o maior de todos os bens, a educação.

A Jacinto Couto (in memoriam), pelas lições que não se apagam. 
A Deus, fonte de luz, verdade e vida.

Ao Professor Doutor José Rogério Cruz e Tucci, pela confiança, incentivo e apoio dispensados durante o curso e na fase de orientação.

Ao Professor Doutor Remo Caponi, pela acolhida, apoio e oportunidade de realização de pesquisas junto à Università degli Studi di Firenze - Itália.

Ao Tribunal de Justiça do Estado do Espírito Santo, na pessoa do atual Presidente Des. Dr. Manoel Alves Rabelo, pela oportunidade na realização deste curso de doutorado.

Ao Professor Doutor Flávio Cheim Jorge, pelas inúmeras vezes que me estendeu às mãos.

A Professora Maria Aparecida d`Ávila Couto e Silva, pela valiosa ajuda na correção dos textos.

Aos Professores do Curso de Doutorado em Direito Processual da USP, pela paciência e incentivo no percurso.

Aos amigos arcadianos Guilherme Recena, Renato Beneduzi e Douglas Ribeiro. 
"Sobre muito fastidioso, é este trabalho sumamente difícil: os defeitos hão de ser muitos, e mesmo talvez nele se notem grandes erros, mas ninguém me poderá roubar o mérito de ter feito esforços por empregar utilmente meu tempo. Em todo o caso, a censura que lealmente me for feita, por certo há de ser muito mitigada pelo censor, se ele chegar a ter consciência da minha boa vontade em acertar". (Souza Pinto).

Afinal "o conhecimento é, pois, uma aventura incerta que comporta em si mesma, permanentemente, o risco de ilusão e de erro". (Edgar Morin).

Mas mesmo assim, resta uma certeza:

"el creer todo descubierto,

es um error muy profundo,

es tomar el horizonte

por los límites del mundo". (Jeremías Bentham) 


\section{RESUMO}

COUTO, Camilo José d'Ávila. Dinamização do ônus da prova: teoria e prática. 2011. 279 f. Tese (Doutorado) - Faculdade de Direito, Universidade de São Paulo-USP, São Paulo, 2011.

Pesquisa desenvolvida na área do direito processual civil por intermédio de análise bibliográfica, baseada na averiguação de legislação, doutrina e jurisprudência pátria e estrangeira, pertinentes à teoria e prática da dinamização do ônus da prova e, em efeito, ao dogma do ônus da prova. Dinamizar o ônus da prova é atribuir o caráter dinâmico ao referido dogma, permitindo ao magistrado, quando da utilização da regra de julgamento, transformar a regra estática de distribuição do ônus da prova em algo dinâmico, ativo, observando determinados elementos conceituais e estruturais. A dinamização do ônus da prova é um instrumento jurídico que soluciona a impossibilidade de se formular um critério geral de distribuição do ônus da prova que satisfaça todas as hipóteses de aplicação do direito diante da existência de incerteza, de dúvida quanto à situação fática, quando do provimento final do juiz, momento em que deverá decidir sobre um fato incerto. Como indica sua própria denominação, retrata a capacidade de ser flexível, sendo sua maior característica a adaptabilidade aos casos concretos para garantir o direito material de quem o realmente tem, estando assim em perfeita sintonia com o princípio da efetividade da tutela jurisdicional. A teoria da dinamização do ônus da prova não objetiva conceder aos magistrados amplos poderes a ponto de permitir arbitrariedades. Contudo, confere-lhes, diversamente da distribuição rígida, pré-estabelecida e em abstrato, considerável grau de poder interpretativo, pois para aplicá-la, é necessário, diante da ausência de certeza oriunda da inércia da respectiva parte na produção da prova ou de sua insuficiência, utilizar a regra de julgamento sob enfoque, após analisar as circunstâncias específicas do caso concreto. Para isso é condição imprescindível a averiguação de qual das partes tem maior facilidade fática e jurídica na produção da prova, se uma das partes está em situação de desigualdade econômico-financeira e/ou técnica perante a outra, se a prova é complexa, bem como se a prova a ser produzida configura uma prova diabólica para a parte onerada. Em síntese, à luz dos preceitos constitucionais da inafastabilidade da 
jurisdição, da igualdade entre as partes, do direito à prova, do devido processo legal, identificar quais situações em que os critérios fixos estabelecidos pela lei quanto à distribuição do ônus da prova não se mostram adequados e eficazes para atingir o seu fim. A parte teórica está estruturada sob uma visão publicista do processo, com destaque à atividade processual das partes dimensionada em uma concepção cooperativa de processo. Ponto marcante desta pesquisa é aquele que identifica e imputa ao magistrado, essencialmente na fase do saneamento do processo, o dever de informar às partes de que, naquele caso concreto, poderá aplicar a dinamização do ônus da prova, caso seja necessário utilizar a regra de julgamento do ônus da prova, advertindo-as quanto às consequências de eventual inércia e do dever de colaboração na busca da verdade. Este dever consiste em um meio teórico, aliado à prática procedimental, que permite ao magistrado alertar às partes que a dinamização do ônus da prova poderá ser aplicada no momento oportuno, como regra de julgamento e, ao mesmo tempo, cientificá-las quanto à postura que devem adotar em âmbito de produção de provas, permitindo-lhes que exercite de forma plena o direito constitucional à produção de provas e, ainda, evitando que o direito constitucional à ampla defesa e contraditório seja transgredido. Este dever de informação específica se harmoniza com o princípio fundamental do processo civil expresso na cláusula constitucional do due process of law. A teoria da dinamização do ônus da prova operacionaliza um parodoxo de extrema relevância para a ciência jurídica, expresso na possibilidade do aumento de certeza versus possibilidade de diminuição das desigualdades na ausência de certeza fática. A regra de juízo ganha ainda mais relevância em um modelo de processo no qual a verdade não é um de seus escopos, como o nosso modelo e estrutura de processo civil. A pesquisa está dividida em quatro partes principais. Na primeira, o tema da prova é apresentado sob a concepção de direito, de dever e de ônus. Na segunda, o dogma do ônus da prova é analisado sob a ótica da modernidade. Na terceira, estão fixados os elementos conceituais e estruturais, bem como os fundamentos da aplicabilidade, inclusive de lege lata, da teoria e da prática da dinamização do ônus da prova. Na última parte são apresentadas as perspectivas de inserção da dinamização do ônus da prova no direito positivo brasileiro, em âmbito do processo civil.

Palavras-chave: Prova. Ônus. Dinamização. Ônus da prova. Dinamização do ônus da prova. 


\begin{abstract}
COUTO, Camilo José d'Ávila. Making the burden of proof dynamic: theory and practice. 2011. 279 f. Doctoral dissertation thesis. Law school, University of São Paulo (USP), São Paulo, 2011.

The present research was carried out in the area of legal process by conducting a review of literature and consulting the current legislation, doctrine, homeland and foreign jurisprudence, which concerns to the theory and practice of the dynamism of the burden of proof - and by a certain extent, to the dogma of the burden of proof. Making the burden of proof dynamic is to attribute a vigorous character to the referred dogma, allowing the magistrate - when one is to judge - to transform the static rule of burden of proof distribution into something flexible, active, by observing certain conceptual and structural elements. Making the burden of proof dynamic is a jurisdictional instrument that could solve the impossibility of formulating a general criterion of its distribution, fulfilling all hypotheses of Law practice when one is before uncertainty, doubt as for the phatic situation or the judge's final word, in a moment when one is to decide on an uncertain fact. As it is indicated by its own meaning, it depicts the capacity of being flexible, being its greatest feature the adaptability to concrete cases in order to guarantee the material right of those who really deserve it, thus being in perfect harmony with the principle of the effectiveness of legal protection. The burden of proof dynamism theory does not aim at granting the magistrate a broad power and not even permit arbitrarinesses. However, it is conferred to them, differently from the rigid, pre-established and abstract distribution, a considerable degree of interpretative power, because in order to apply it, it is necessary, before the lack of decision making which comes from the irrespective idleness of proof production or from its insufficiency, adopt the judgment rule in focus, after specific circumstances of the concrete case have been previously analyzed. For that, it is paramount the checking of which part has a greater phatic and jurisdictional ease in proof production, if one of the parts is in a social-economic and/or technical unequal level in comparison to each other, if the proof is complex, as well as if the proof to be produced turns out to be a diabolic test to the responsible part. In short, in the light of the constitutional precepts, of the right to the proof, of the due legal process of law, it can be
\end{abstract}


said that to identify in which situation pre-established criteria by law concerning the burden of proof are not suitable enough to meet its end. The theoretical part of this paper is based on a publicist view of the legal process, highlighting the legal process of the parts contextualized in a cooperative conception of the legal process. A remarkable point of this research is the argument that identifies and attributes the magistrate - essentially when solving a legal process - the obligation to inform one that in a concrete case, it would be possible to make the burden of proof dynamic, in case it is necessary to adopt the rule of the burden of proof judgment, warning about the tentative consequences of an eventual inertia and about the duty to collaborate when seeking the truth. This obligation goes hand in hand with a theoretical environment and with the procedural practice, which permits the magistrate to warn one that making the burden of proof dynamic may be applied in an appropriate moment as a judgment rule, and at the same time, make them aware of how to behave in a situation of proof production, letting one widely exercise the constitutional right to proof production, and furthermore, avoiding that the constitutional right to a better defense be violated. This duty of providing specific information goes in harmony with the fundamental principle of the legal process expressed in the possibility of raising certainty versus the possibility of decreasing inequality in the absence of phatic sureness. The rule of judgment becomes even more relevant in a legal process model where the truth is not one of its scopes, as our model and structure of legal process format. This research is divided into four main parts. The first one, the proof theme is introduced under the conception of right, duty and burden. In the second part, the burden dogma is analyzed in the light of modernity. In the third segment, structural and conceptual elements are defined, as well as the foundations of applicability, the lege lata concept, the theory and practice of making the burden of proof dynamic. In the last part, the application perspectives of the burden of proof dynamics in the positive Brazilian Law are introduced, in a legal process milieu.

Keywords: Proof. Burden. Dynamic. Burden of proof. Burden of proof dynamic. 


\section{RIASSUNTO}

COUTO, Camilo José d`Ávila. L 'onere della prova dinamico: teoria e pratica. 2011. 279 f. Tesi di laurea (Ph.D.) - Facoltà di Giurisprudenza, Università di São Paulo-USP, São Paulo, 2011.

La ricerca sviluppata nel settore del diritto processuale civile attraverso la revisione della letteratura, sulla base della constatazione di legge, dottrina e giurisprudenza patria e straniera, rilevanti per la teoria e la pratica dell'onere della prova dinamico e, di fatto, il dogma dell'onere della prova. Promuovere il dinamismo dell'onere della prova è assegnare il carattere dinamico di tale dogma, consentendo al magistrato, quando si utilizza la regola del giudizio, trasformando regola statica per distribuire l'onere della prova a qualcosa di dinamico, attivo, osservando alcuni elementi concettuali e strutturali. La promozione del dinamismo dell'onere della prova è uno strumento giuridico che affronta l'impossibilità di formulare un criterio generale per la distribuzione dell'onere della prova che soddisfa tutte le ipotesi di applicazione della legge per l'esistenza di incertezze, dubbi sulla situazione di fatto, quando della disposizione finale del giudice, momento in cui deciderà su un fatto incerto. Come il nome stesso indica, descrive la capacità di essere flessibile, e la sua caratteristica più importante è l'adattabilità ai casi specifici per garantire il diritto materiale per coloro che hanno davvero, di essere in perfetta armonia con il principio della tutela giurisdizionale effettiva. La teoria della dell 'onere della prova dinamico non è inteso a garantire ampi poteri ai giudici per consentire punto arbitrario. Tuttavia, si dà loro, in modo diverso della distribuzione rigida, pre-stabilite e in astratto, un grado considerevole di potere interpretativo, in quanto per l'applicazione è necessario, data la mancanza di certezza derivante dalla inazione della loro quota nella produzione di prove o sua insufficienza, l'uso del processo ai sensi del approccio della regola, considerate le circostanze specifiche del caso. Prerequisito per questo è l'accertamento di quale parte ha la capacità di produrre la prova di fatto e di diritto, se una delle parti è in una situazione di disparità economiche e/o tecnica di fronte all'altro, se la prova è complessa e se la prova da produrre configurarsi una prova diabolica alla parte gravata. In sintesi, alla luce dei precetti 
costituzionali di non allontanarsi dalla giurisdizione, della parità tra le parti, del diritto alla prova ed a un processo legale, individueranno le situazioni in cui i criteri fissati stabiliti dalla legge in materia di ripartizione dell'onere della prova non sono adeguati ed efficaci per raggiungere il suo fine. La parte teorica è strutturata come una visione pubblica del processo, con particolare attenzione alle attività processuali delle parti in scala in un concetto cooperativo del processo. Il punto più importante di questa ricerca è quello che identifica e addebita al magistrato, in sostanza, nella fase della riorganizzazione del processo, il dovere di informare alle parti che in quel caso, è possibile applicare la teoria dell'onere della prova dinamico, se necessario, utilizzare la regola dell'onere della prova in giudizio, mettendoli in guardia sulle conseguenze dell'inazione e del dovere di cooperare alla ricerca della verità. Questo dovere è costituito in modo teorico, accoppiato alla pratica procedurale, consentendo al giudice di avvertire le parti che la dinamica dell'onere della prova potrebbe essere applicata in modo tempestivo, come regola di giudizio e, al tempo stesso, chiarire loro come che dovrebbe prendere parte alla produzione di elementi di prova, permettendo loro di esercitare pienamente il loro diritto costituzionale alla produzione di prova e per evitare che il diritto costituzionale di ampia difesa e contraddittorio sia violato. Questo dovere di informazione specifiche si armonizzano con il principio fondamentale del processo civile previsto nella clausola costituzionale del "due process of law". La teoria dell'onere della prova dinamico opera un paradosso di grande rilevanza per la scienza giuridica, espresso nella possibilità di maggiore certezza rispetto alla possibilità di ridurre le differenze, in assenza di certezza di fatto. La regola del giudizio è ancora più importante in un modello di processo in cui la verità non è uno dei loro scopi, come il nostro modello e la struttura di procedura civile. La ricerca è divisa in quattro parti principali. In un primo momento, la questione della prova viene presentata nella concezione del diritto, dovere ed onere. In un secondo momento, il dogma dell' onere della prova è analizzata dal punto di vista della modernità. Nel terzo set sono gli elementi concettuali e strutturali, ed i motivi del ricorso, tra cui la "lege lata", la teoria e la pratica dell'onere della prova dinamico. Nella parte finale presenta la prospettiva di entrare la teoria dell'onere della prova dinamico nel diritto positivo brasiliano, nell'ambito del processo civile.

Parole chiave: Prova. Onere. Dinamico. Onere della prova. L`onere della prova dinamico. 


\section{SUMÁRIO}

I CONCEPÇÕES CONTEMPORÂNEAS SOBRE PROVA

1.1 PROVA

1.1.1 Aspectos essenciais: conceito, relevância, finalidade, direito probatório.

1.2 PROVA COMO DIREITO

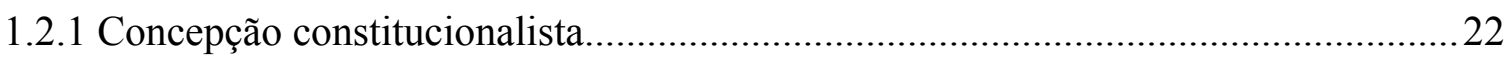

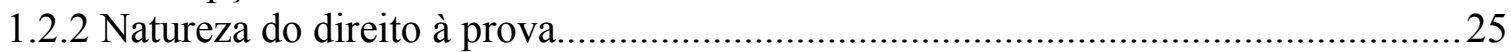

1.2.3 Direito das partes à prova e o dever de informação do juiz.......................................26

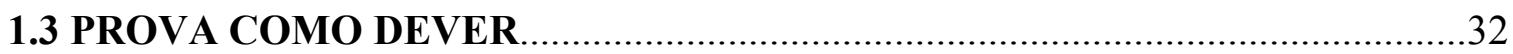

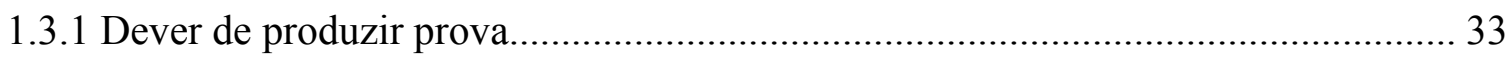

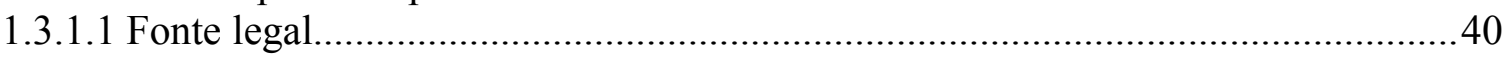

1.3.2 Crítica à noção de ônus processual e dever de provar............................................ 42

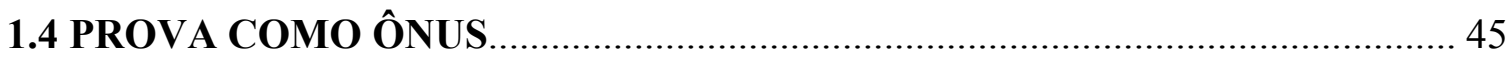

II DOGMA DO ÔNUS DA PROVA ............................................................ 49

2.1 DOGMA DO ONUS PROBANDI NA MODERNIDADE................................ 49

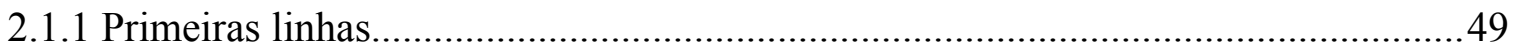

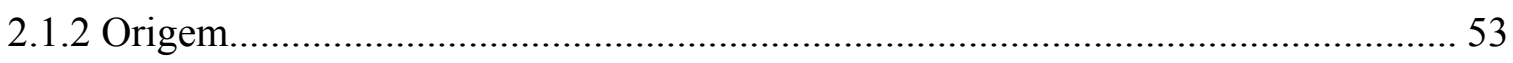

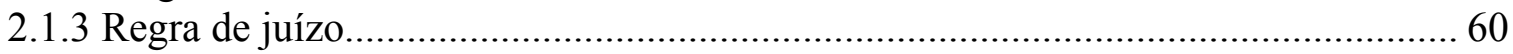

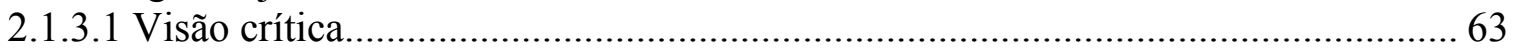

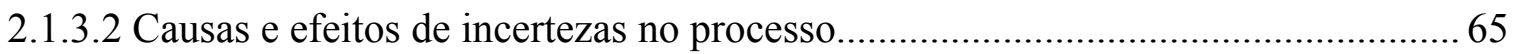

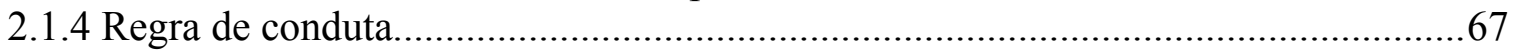

2.1.5 Nascimento da distinção entre ônus da prova objetivo e subjetivo.......................... 71

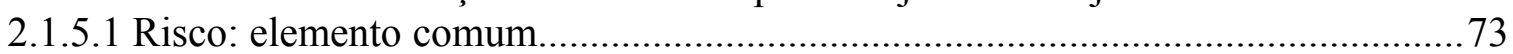

2.1.6 Ônus da prova no direito processual civil brasileiro.............................................. 76

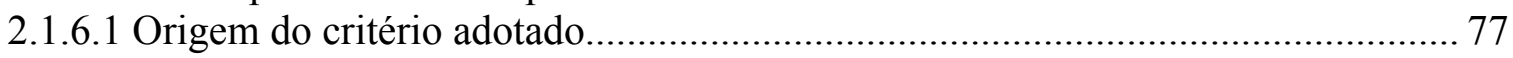

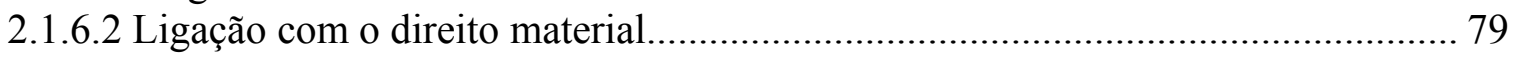

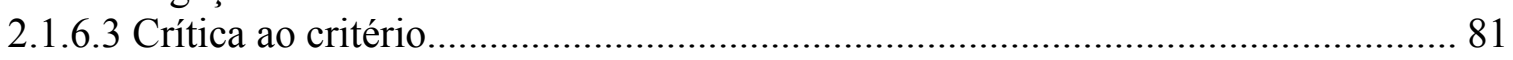

2.1.7 Livre apreciação da prova, regras de experiência e presunções................................ 84

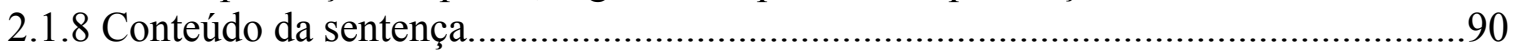

III TEORIA DA DINAMIZAÇÃO DO ÔNUS DA PROVA.......................94

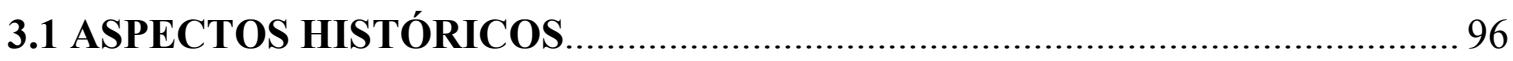

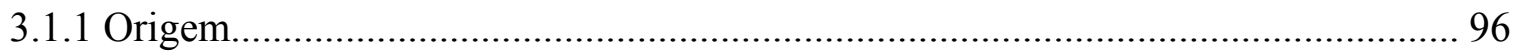

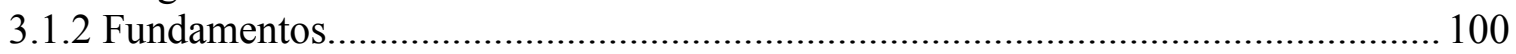

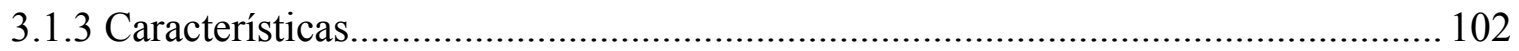

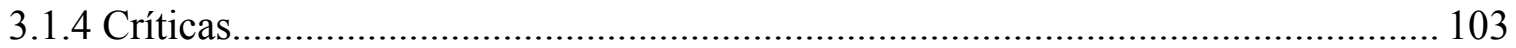




\subsection{DINAMIZAÇ̃̃O DO ÔNUS DA PROVA NO PROCESSO CIVIL BRASILEIRO.

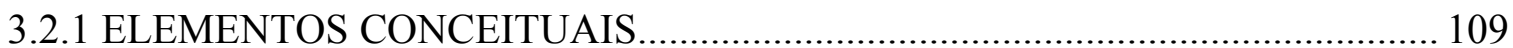

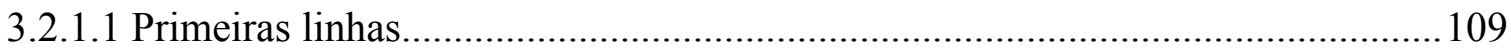

3.2.1.2 Conceito de ônus processual versus dinamização...............................................112

3.2.1.3 Distribuição do ônus da prova: conceito, finalidade e forma................................ 115

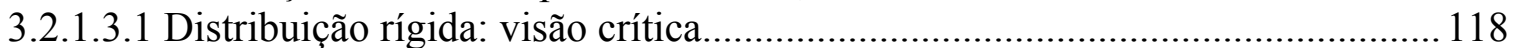

3.2.1.4 Dinamização versus inversão do ônus da prova.................................................. 120

3.2.1.5 Atuação do juiz e das partes: novo paradigma......................................................128

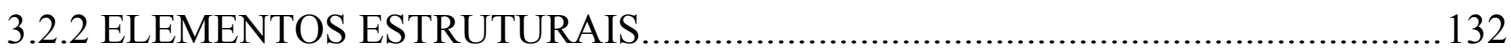

3.2.2.1 Requisitos de aplicabilidade da dinamização do ônus da prova............................ 132

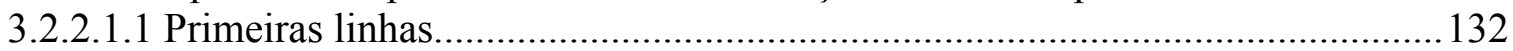

3.2.2.1.2 Impossibilidade de produção da prova.........................................................135

3.2.2.1.3 Desigualdade econômico-financeira................................................................ 137

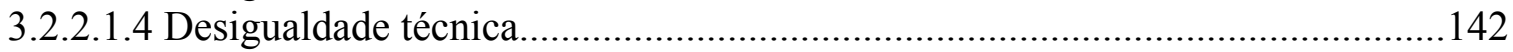

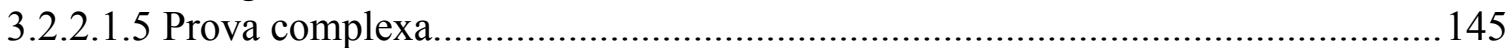

3.2.2.1.6 Prova diabólica........................................................................................150

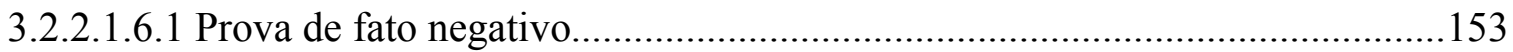

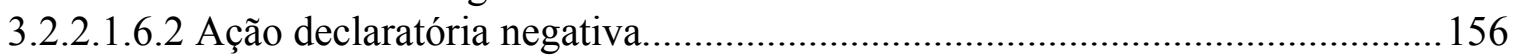

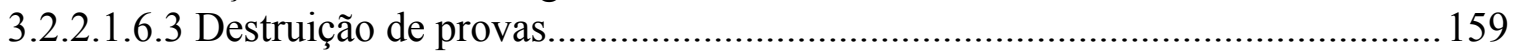

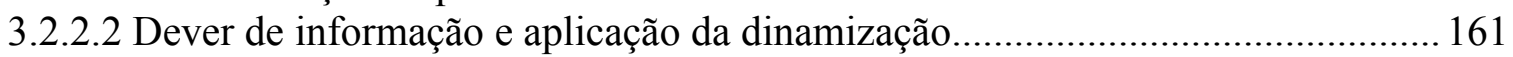

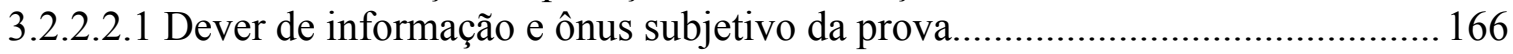

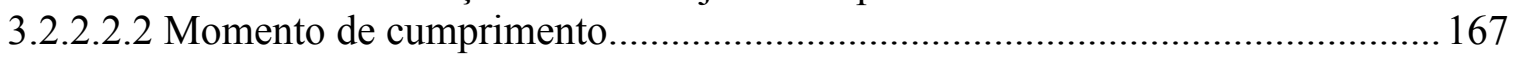

3.2.2.2.3 Consequências da inobservância...................................................................171

3.2.2.3 Momento da aplicação da dinamização......................................................... 172

3.2.2.3.1 Aplicação da dinamização em sede recursal.......................................................175

3.2.2.3.2 Aplicação da dinamização antes da sentença: impedimento teórico.................. 178

3.2.2.4 Limites na aplicação da dinamização pelo Estado-juiz.......................................... 190

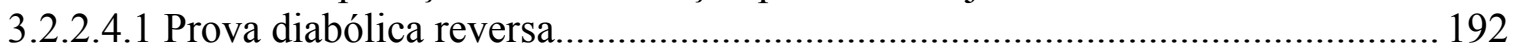

3.2.2.5 Poder-dever, dinamização, fundamentação e sentença........................................ 194

3.2.2.6 Consequências da aplicação da dinamização no ordenamento jurídico................ 196

3.3 FUNDAMENTOS DA APLICABILIDADE DA DINAMIZAÇÃO....................201

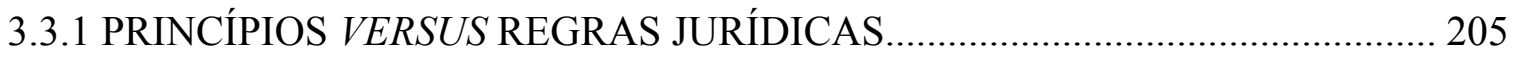

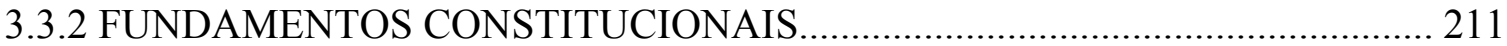

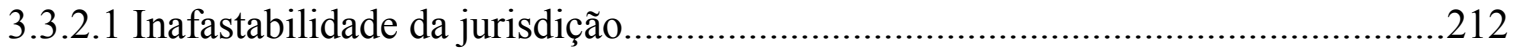

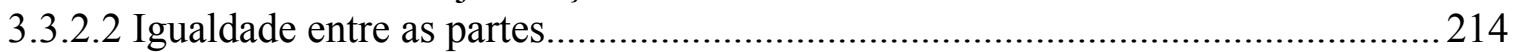

3.3.2.3 Direito à prova e devido processo legal............................................................... 216

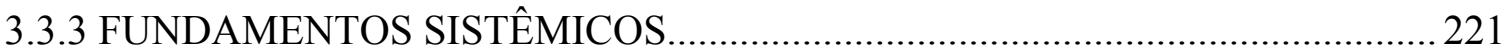

3.3.3.1 Justiça: razão e fim axiológico do sistema jurídico............................................... 221

3.3.3.2 Visão cooperativa do processo e a produção da prova........................................... 223

3.3.4 APLICAÇÃO DA DINAMIZAÇÃO NA JURISPRUDÊNCIA...............................229 
IV PERSPECTIVAS DE INSERÇÃO DA DINAMIZAÇÃO DO ÔNUS DA PROVA NO DIREITO POSITIVO.

4.1 LEY N ${ }^{\circ}$ 01/2000 - LEY DE ENJUICIAMIENTO CIVIL DE ESPAÑA................... 237

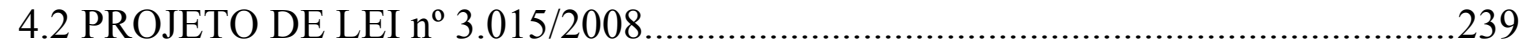

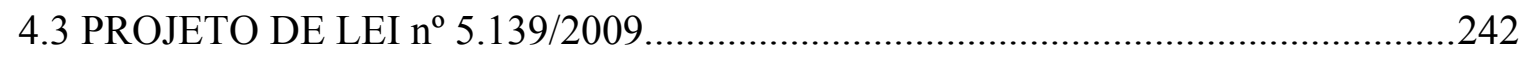

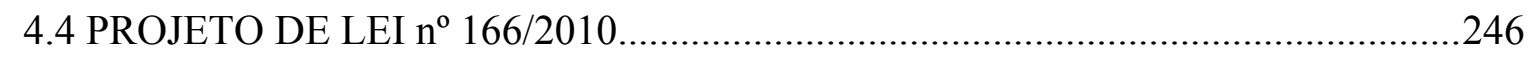

V CONCLUSÃO

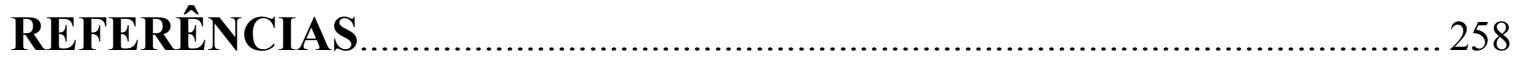




\section{CONCEPÇÕES CONTEMPORÂNEAS SOBRE PROVA}

A prova, lato sensu, quaisquer que sejam as suas concepções, é um dos temas mais antigos do direito e, quiçá, da própria história da humanidade. Afinal, também os dados históricos precisam de prova.

Sob determinada ótica, a filosófica e a sociológica, esse tema é mais antigo que o próprio direito, se pensarmos tal termo como algo institucionalizado ou mesmo préinstitucionalizado. Nessas searas, o tema da prova estava umbilicalmente ligado ao tema da justiça. A justiça, para ser distribuída em concreto, necessitava de demonstração, mesmo que essa distribuição ocorresse por mãos divinas.

Transcorridos os séculos, o tema da prova sofreu profunda e imprescindível evolução, sobretudo sob o ângulo da racionalidade, fato decorrente da própria evolução da sociedade em várias esferas do conhecimento humano. Não há falar-se em ciência sem racionalidade.

No mundo contemporâneo, sob o viés da ciência jurídica, não obstante a racionalidade científica que o tema da prova está inserido, mesmo diante de inúmeros estudos doutrinários a respeito, abordando seus diversos aspectos, é possível afirmar que ainda subsistem significativas dúvidas, inquietações e discussões sobre esse universo: o tema da prova.

Afinal, como a sociedade é dinâmica e as mudanças nas relações sociais ocorrem com grande velocidade, o tema da prova, assim como o do direito, está sujeito a esse dinamismo e a ele deve ser adequado.

Em efeito, resta incontestável a impossibilidade de definir e analisar completamente a prova e as questões que dela derivam, principalmente o relativo ao descobrimento da 
verdade dos fatos no processo, restringindo tais objetos exclusivamente à dimensão jurídica. ${ }^{1}$

Reduzindo a extensão das dificuldades que o tema envolve nos dias atuais, i.e., focando o problema nos limites do direito processual civil, convém analisar a seguir, se a prova consiste em um direito, um dever, um ônus ou se é possível falar da existência de uma variação ou conjugação de conceitos da prova de acordo com as posições advindas da respectiva relação jurídica processual.

Em outras palavras, necessário averiguar se a prova pode assumir, no contexto da relação jurídica processual, concepções diversas, isolada e/ou simultaneamente, como a de direito, de dever e de ônus. ${ }^{2}$

Não é novidade para os estudiosos do nosso direito processual civil, nem para os do processo civil de outros países, que a concepção de prova como ônus é a mais tradicional, a mais clássica. Nesse mesmo passo, já não resta dúvida que essa concepção, que identifica uma verdadeira postura metodológica para o tema, precisa ser aperfeiçoada diante do próprio dinamismo anteriormente mencionado.

Essa forma de analisar e compreender o tema, que ora se propõe intencionalmente, tem importante vinculação científica com o objeto central da tese. A teoria da dinamização do ônus da prova além de inserir, confere similar importância teórica e prática à concepção de prova como direito, como dever e como ônus, no bojo da relação jurídica processual.

Buscando corroborar as assertivas inseridas nesta pesquisa, será imprescindível recorrer ao direito comparado, i.e., ao método comparativo, por consistir em um modo de ser da experiência jurídica. ${ }^{3}$

\footnotetext{
${ }^{1} \mathrm{O}$ tema da prova não se exaure na dimensão jurídica e tende a projetar-se para fora dela e, ainda, a penetrar em outros campos, v.g., da lógica, da epistemologia e da psicologia. Em decorrência, o jurista não consegue mais estabelecer o que é a verdade dos fatos no processo e a que servem as prova, sem antes afrontar escolhas filosóficas e epistemológicas de ordem mais geral. (tradução nossa). TARUFFO, Michele. La prova dei fatti giuridici: nozioni generali. Milano: Giuffrè, 1992. p. 2-3, 5.

${ }^{2}$ Estudar a prova como ônus é, ao mesmo tempo, preparar seu exame sob outros ângulos em relação aos sujeitos parciais (dever e direito) e mesmo com referência ao poder exercido pelo Estado, na pessoa do juiz. (grifos do autor). YARSHELL, Flávio Luiz. Antecipação da prova sem o requisito da urgência e direito autônomo à prova. São Paulo: Malheiros, 2009. p. 48.
} 


\subsection{PROVA}

\subsubsection{Aspectos essenciais: conceito, relevância, finalidade, direito probatório}

Em âmbito do processo, instrumento da jurisdição, não existe matéria que espelhe o movimento político, social e cultural do mundo contemporâneo, com intensidade e perfeição maiores, que o direito às provas. ${ }^{4}$

Analisando o processo sob o ângulo intrínseco, definitiva e precisa é a afirmativa de que a prova, na maioria das vezes, é a encruzilhada decisiva do processo, advindo daí sua importância incontestável. ${ }^{5}$

A prova, qualificada como instituto técnico-jurídico, tem a função de assegurar o caráter racional da própria atividade processual e, consequentemente, da própria atividade jurisdicional. ${ }^{6}$

\footnotetext{
${ }^{3}$ Resta evidente que a expressão direito comparado não designa um setor definido e particular da experiência jurídica, mas sim um método para estudar e um modo de ser daquela experiência. É um método que tem um corpo de regras técnicas não elidíveis, mas que oferece espaços e permite deduções em seu emprego, segundo a necessidade aplicativa (do direito privado, do público, do direito penal, do direito processual etc.) [...] Em suma, nesta ótica, a comparação é a análise da experiência alheia para um juízo de valor, em vista de uma síntese inevitável destinada ao ordenamento de origem. Com todos os riscos que a valoração e ainda as escolhas e o propor comportam. Este é o ensinamento de Ada Pellegrini Grinover que na comparação tem sempre visto um instrumento de conhecimento e de reforma inspirada pela paixão civil e nunca pela mera erudição. (grifo do autor - tradução nossa). VIGORITI, Vicenzo. Sul metodo comparativo. In YARSHELL, Luiz Flávio; MORAES, Maurício Zanoide de. (coord.). Estudos em homenagem à professora Ada Pellegrini Grinover. São Paulo: DPJ Editora, 2005. p. 861-862.

${ }^{4}$ DENTI, Vittorio. Estudios de derecho probatório. Traducción Santiago Sentís Melendo y Tomás A. Banzhaf. Buenos Aires: EJEA, 1974. p. 155. Originalmente: "En el campo del proceso no hay otra materia que refleje el movimiento político, social y cultural del mundo contemporáneo con mayor intensidad que el derecho de las pruebas".

${ }^{5}$ BARBOSA MOREIRA, José Carlos. O juiz e a prova. Revista de Processo, São Paulo, ano 9, n. 35, p. 178184, abril-junho 1984. p. 178. Na visão de CONTE, Mario. Le prove civile. $2^{\mathrm{a}}$ ed. Aggiornata alla legge di riforma del processo civile 18 giugno 2009, n. 69. Milano: Giuffrè Editore, 2009. p. 47, a prova constitui o fulcro do processo, qualquer que seja o modelo que o legislador adotou. [...] Por este motivo, a doutrina sagazmente observa que sem a prova e, ainda, o processo, o direito de um sujeito é mero flatus voci. (tradução nossa).

${ }^{6}$ Nesse sentido VERDE, Giovanni. Prova: b) teoria generale e diritto processuale civile. Enciclopedia del diritto. Milano: Giuffrè, 1958. v. 37. p. 592. Ainda, GOMES FILHO, Antônio Magalhães. Direito à prova no processo penal. São Paulo: Revista dos Tribunais, 1997. p. 56. Vale lembrar que no sistema do direito primitivo, o sistema probatório era composto pelas provas ordálicas, no qual prevalecia o juízo divino, em contraposição ao juízo racional.
} 
Falar de prova $^{7}$ é falar de fatos e, precisamente, em sua demonstração, considerando precipuamente a realizada em juízo - produção da prova, ${ }^{8}$ sem desconsiderar o fenômeno de sua obtenção, precedente lógico daquela.

O vocábulo prova contém em si vários significados, tanto de cunho coloquial quanto técnico-jurídico. ${ }^{9}$ Prova, substantivo feminino, significa demonstração. Prova, em sentido técnico-jurídico, significa o próprio resultado das atividades probatórias. ${ }^{10} \mathrm{Na}$ afirmativa há prova suficiente a ensejar uma condenação, significa que após a realização das atividades probatórias, o fato foi demonstrado.

Provar, verbo transitivo, significa estabelecer a verdade, ${ }^{11}$ a realidade dos fatos, demonstrar. Juridicamente, provar significa demonstrar em juízo as alegações firmadas pelas partes. A título de verificação desta afirmativa anterior, é perfeitamente possível, substituir o vocábulo prova nas expressões correntes na doutrina pelo vocábulo demonstração, sem que isso modifique essencialmente o seu significado técnico, v.g.:

\footnotetext{
${ }^{7}$ Não se pode esquecer que a noção de prova também pertence a outros domínios da ciência humana, v.g., da filosofia, uma vez que se refere ao parcialmente desconhecido campo das operações do intelecto, na identificação e comunicação do conhecimento verdadeiro. Cf. DELLEPIANE, Antônio. Nova teoria da prova. 2. ed. Tradução Érico Maciel. Rio de Janeiro: José Konfino, 1958. p. 54. Segundo o autor, prova é demonstração de uma verdade enunciativa. Para a filosofia, verdade enunciativa é a expressão no discurso, do intellectus, que pode ser comprovado pela verificação da existência daquilo que foi dito. Contudo, esta não é a única possibilidade de verdade no discurso. A verdade do discurso, assim, é a adequação do discurso à coisa. "Daí o conceito de verdade oriundo da lógica: adaequatio intelectus ad rem".

8 Apesar da tradicional vinculação entre produção da prova e processo judicial, há quem defenda haver autêntica produção de prova também fora do âmbito do processo judicial. YARSHELL, Antecipação da prova..., 2009, p. 32-33 e 45.

${ }^{9}$ PISANI, Andrea Proto. Lezioni di diritto processuale civile. $5^{\mathrm{a}}$ ed. Napoli: Jovene Editore, 2010. p. 404, reputa essa pluralidade de significados do termo prova à pobreza de léxico. Sustenta que o termo prova pode indicar: a) os instrumentos de conhecimento dos fatos, também chamados de fontes materiais de prova; b) o procedimento através do qual os instrumentos de conhecimento são formados e apresentados ao juízo; c) a atividade lógica de conhecimento dos fatos, sobretudo as atividades de percepção e dedução; d) o resultado da atividade lógica de conhecimento. (tradução nossa). Ainda sobre as diversas acepções quanto ao vocábulo 'prova', cf. SANTOS, Moacyr Amaral. Prova judiciária no cível e comercial. 4. ed. São Paulo: Max Limonad, 1970. v. 1. p. 1-2. Cf., ainda, EGGLESTON, Richard. Prova, conclusione probatoria e probabilità. Milano: Giuffrè Editore, 2004. p. 191-192.

${ }^{10}$ Nesse sentido CONTE, Le prove..., 2009, p. 4.

${ }^{11}$ A prova tem por objetivo a verdade, ou, pelo menos, certa classe de verdade; [...] O verdadeiro é o que está demonstrado ou comprovado em forma tal que não admite dúvida; [...] Método e verdade se correlacionam porque o primeiro outra coisa não é senão o meio de encontrar a última. Prova e verdade acham-se também correlacionadas e a tal extremo que se poderia dizer que não há verdade sem prova, posto que a prova é a pedra de toque, o meio de aquilatar, de adquirir a evidência inquestionável da verdade, [...] Toda verdade deve resistir ao choque da dúvida e sair triunfante dela por meio da prova, [...] E, se método e prova são correlativos com a verdade, não é menos certo que são correlativos entre si, e estaríamos mesmo autorizados a acrescentar que o estudo da prova faz parte da teoria do método, que é como que a sua culminação. [...] Não há, pois, método nem verdade sem prova. Cf. DELLEPIANE, Nova teoria..., 1958, p. 40 et seq.
} 
objeto de demonstração; ônus da demonstração; fontes de demonstração; meios de demonstração; valoração da demonstração.

Nesse âmbito, provar consiste na realização de um conjunto de atividades de demonstração e verificação dos fatos relevantes para o julgamento da demanda, apresentados pelas partes, visando estabelecer a verdade ${ }^{12}$ desses fatos. Esse conjunto de atividades de demonstração e verificação dos fatos relevantes é que denominamos de direito probatório. ${ }^{13}$

O direito probatório, em abstrato, é composto de vários membros que, vistos em conjunto, lhe dá concretude, constituindo um corpo inteiro. Em outras palavras, o direito probatório - gênero - é composto por vários elementos - espécies - que, analisados contextualmente, nos permite conceituá-lo de forma precisa. Diante desse raciocínio, é possível afirmar que o direito probatório é formado pelas seguintes partes: a) objeto: ${ }^{14}$ são as alegações fáticas apresentadas pelas partes plausíveis de demonstração por via da prova; b) ônus da prova: compreende a distribuição do encargo de produzir provas e suas

${ }^{12}$ Em âmbito do direito processual civil recorrem-se com frequência, como critério de aproximação da verdade, a conceitos como o de verossimilhança, probabilidade quantitativa e probabilidade lógica ou indutiva. Parte da doutrina considera prescindível a verdade e suficiente a mera verossimilhança dos fatos. [...] o que é suficiente, muitas vezes, para a validade e a eficácia da sentença é a verossimilhança dos fatos. [...] Por isto é que se pode dizer que, para subsistir uma determinada decisão, suficiente é a verossimilhança, não se colocando a verdade como absolutamente essencial. Cf. ALVIM, Arruda. Manual de direito processual civil. 6. ed. São Paulo: Revista dos Tribunais, 1997. v. 1. p. 437-438. Ainda sobre o tema, i.e., a verdade, TARUFFO, La prova dei fatti..., 1992, p. 7-58, discorre sobre a negação da verdade, a irrelevância da verdade e a verdade possível no processo civil. Afirma que a ideologia que se coloca em contraste com a idéia de busca da verdade é a mesma que vê o processo civil essencialmente como um instrumento de resolução de conflitos e, em particular, aquele que assume a forma de controvérsia jurídica entre as partes. Tal contraste entre essa concepção de processo civil e a busca da verdade sobre os fatos da demanda surge quando se afirma que a busca da verdade não pode ser o escopo de um processo civil orientado para a solução dos conflitos, uma vez que se trataria de finalidades diversas e incompatíveis. Em efeito, existe um modelo processual considerado "bom", que é o dispositivo, no qual a busca da verdade representa um nãovalor ou um desvalor, e um modelo processual dito "ruim", que é o inquisitivo, no qual a busca da verdade é considerada um valor. Para este último modelo a verdade dos fatos configura um escopo do processo. Todavia, Michele considera que a incompatibilidade entre a busca da verdade e o modelo dispositivo não é absoluta. (p. 16-17; 22). Cf. DAMASKA, Mirjan R. I volti della giustizia e del potere: analisi comparatistica del processo. Traduzione di Andrea Giussani e Fabio Rota. Bologna: Il Mulino, 1991. p. 158, 173, 337,352 e ss., sobre essa concepção de processo civil considerada em muitos ordenamentos como um dos arquétipos fundamentais do processo civil. Vale ressaltar que a doutrina italiana reputa à Carnelutti a mais coerente racionalização desta concepção de processo civil, principalmente em suas obras Sistema di diritto processuale civile (1936) e Diritto e processo (1958).

${ }^{13}$ Nesse sentido DINAMARCO, Cândido Rangel. Instituições de direito processual civil. 6. ed. rev. e atual. São Paulo: Malheiros, 2009. v. 3. p. 42-44.

${ }^{14}$ TARUFFO, Michele. Studi sulla rilevanza della prova. Padova: CEDAM, 1970. p. 37 e 53, estabelece uma distinção entre objeto de prova e thema probandum. Este consiste no contexto probatório, o que engloba todas as alegações de fato controversas, pertinentes e relevantes. Já o objeto de prova concerne especificamente a essa ou àquela assertiva a ser provada. 
respectivas consequências diante do seu total ou parcial descumprimento; c) fontes de prova: consistem nos elementos exteriores sobre os quais incidem as atividades probatórias; d) meios de prova: ${ }^{15}$ consistem nas próprias atividades probatórias processualmente realizadas visando a demonstração das alegações das partes; e) valoração da prova: refere-se ao valor jurídico e ao modo como as provas produzidas pelas partes devem ser apreciadas.

Assim, para as partes, provar tem a conotação de demonstrar os fatos alegados e apresentados em juízo, mormente os relevantes ao julgamento da demanda, visando, com isso, em um primeiro momento, formar o convencimento ${ }^{16}$ do julgador quanto à existência ou inexistência desses fatos, para, em seguida e decorrentemente, obter o resultado pretendido, ou seja, o bem da vida objeto do pedido.

Na doutrina clássica diz-se que a prova, para o juiz, tem a finalidade de demonstrar a verdade a respeito dos fatos alegados pelas partes. Para ele, destinatário ${ }^{17}$ de todas as provas produzidas no processo, não interessa quem as tenha produzido e, sim, que essas tenham sido regularmente produzidas sob o crivo das garantias constitucionais. A prova tem por função formar o provimento jurisdicional. ${ }^{18}$

Na perspectiva contemporânea, a função da prova vai além e absorve outros elementos, não se satisfazendo com a formação de qualquer provimento, mas exigindo um

\footnotetext{
${ }^{15}$ Segundo GOMES FILHO, Antônio Magalhães. Notas sobre a terminologia da prova (reflexos no processo penal brasileiro). In YARSHELL; MORAES, Estudos em homenagem à professora Ada..., 2005, p. 309, os meios de prova referem-se a uma atividade endoprocessual que se desenvolve perante o juiz, com o conhecimento e participação das partes, visando à introdução e à fixação de dados probatórios no processo.

${ }^{16}$ A este respeito, por intermédio do instituto anscheinsbeweis, que incide sobre a avaliação das provas, foi introduzida no processo civil alemão a teoria da verossimilhança prevalente, com base na qual o juiz está autorizado a considerar suficientemente demonstrada a verossimilhança de um fato somente com base em regra de experiência formando desta forma seu convencimento. PATTI, Salvatore. Prove: disposizioni generali. Bologna: Zanichelli Editore, 1987. p. 170. Ainda, GOMES FILHO, Direito à prova ..., 1997, p. 4647.

${ }^{17}$ Com essa visão clássica GRECO FILHO, Vicente. Direito processual civil brasileiro. 18 ed. São Paulo: Saraiva, 2007. v. 2. p. 195-196; MARQUES, José Frederico. Manual de direito processual civil. 7. ed. São Paulo: Saraiva, 1985. v. 2. p. 181-182.

${ }^{18}$ Nesse sentido a clássica lição de SANTOS, Prova Judiciária..., 1970, v. 1, p. 6 e nota 17. Na doutrina estrangeira, por todos, TROCKER, Nicolò. Processo civile e costituzione: problemi di diritto tedesco e italiano. Milano: Giuffrè, 1974. p. 509. Afirma que a atividade probatória representa indubitavelmente o momento central do processo. Estreitamente ligada à alegação e indicação dos fatos, objetiva oferecer ao sujeito judicante a demonstração da verdade dos fatos deduzidos ou relevantes em juízo, ou, mais precisamente, de um grau tal de verossimilhança suficiente a poder excluir o contrário, e assume portanto uma importância fundamental para a formação do provimento jurisdicional. (tradução nossa).
} 
provimento justo e eficiente, dentro da linha metodológica de um processo civil publicista $^{19}$ e de resultados, através do qual o juiz tem o dever de dar efetividade ao princípio do acesso à justiça, na concepção ampla da expressão. ${ }^{20}$

19 É essa visão publicista da prova que permite afirmar que a prova serve ao processo, à verdade, ao convencimento do juiz e à legitimação da coisa julgada, visando, em efeito, o alcance da paz social. RODRIGUES, Marcelo Abelha. Processo civil ambiental. São Paulo: Revista dos Tribunais, 2008. p. 130.

${ }^{20}$ YARSHELL, Antecipação da prova..., 2009, p. 25, considera uma visão limitada do fenômeno probatório a exclusiva e estrita vinculação entre prova e julgamento estatal. 


\subsection{PROVA COMO DIREITO}

\subsubsection{Concepção constitucionalista}

A concepção mais importante do instituto da prova é aquela que a ascende ao status de verdadeiro direito constitucional. ${ }^{21}$ Este direito constitucional diz respeito à produção de provas que, precisamente, nessa seara, reflete a oportunidade que a parte tem (deve ter) de apresentar provas ao juiz de forma ampla.

Entretanto, a amplitude da produção de provas em juízo sofre restrições tanto de ordem constitucional (artigo $5^{\circ}$, inciso LVI, CR/88) - produção de provas obtidas de forma ilícita, quanto de ordem processual (artigo 332, CPC, em interpretação a contrário sensu) produção de provas moralmente ilegítimas. $^{22}$

O direito à prova, todavia, não está expresso na nossa Lei Maior. É um direito derivado $^{23}$ do sentido processual da cláusula do devido processo legal - due process of law, lembrando que esta contém um sentido processual (procedural due process) e um sentido material ou substancial (substantive due process), segundo a doutrina norte-americana, entendimento acolhido pacificamente pela nossa doutrina.

É importante ratificar e reiterar que o devido processo legal, expresso na Constituição Republicana Brasileira de 1988, no artigo 5º inciso LIV (ninguém será

\footnotetext{
${ }^{21}$ No sentido de reconhecimento de um direito à prova na doutrina processual civil derivado dos princípios constitucionais: GOMES FILHO, Direito à prova..., 1997, p. 80; NERY JUNIOR, Nelson. Princípios do processo civil na constituição federal. 5. ed. 2. tir. São Paulo: RT, 1999; BARBOSA MOREIRA, José Carlos. A garantia do contraditório na atividade de instrução. In Temas de direito processual. 3 série. São Paulo: Saraiva, 1984. p. 65-77; LOPES, João Batista. A prova no direito processual civil. 2. ed. São Paulo: Editora Revista dos Tribunais, 2002. p. 162; DINAMARCO, Instituições..., 2009, v. 1, p. 187 e $258 . \mathrm{Na}$ doutrina estrangeira CANOTILHO, José Joaquim Gomes. Estudos sobre direitos fundamentais. Coimbra: Coimbra Editora, 2004. p. 169-170.

${ }^{22}$ A doutrina classifica ainda as limitações ao direito à prova em subjetivas (restritas às partes, terceiros interessados e MP) e em objetivas (admissibilidade de meios de provas, à produção e à valoração).

${ }^{23} \mathrm{Em}$ âmbito de processo civil o direito à prova pode ser ainda abstraído do teor do artigo $8^{\circ}$, item 1 , da Convenção Americana sobre Direitos Humanos (Pacto de São José da Costa Rica) de 1969, cujo texto foi aprovado pelo nosso Congresso Nacional em 26 de maio de 1992 - Dec. Leg. 27. Seu integral cumprimento foi determinado pelo Decreto 678, de 06 de novembro de 1992.
} 
privado da liberdade ou de seus bens sem o devido processo legal), é o alicerce maior que proporciona firme sustentáculo a todos os princípios de direito processual civil, sendo por isso, o princípio fundamental do processo civil. $^{24}$

Em outra vertente da doutrina brasileira e estrangeira, considera-se que o direito constitucional à prova é derivado da garantia constitucional da ação e da defesa. ${ }^{25}$ Argumenta-se que, para se configurar um efetivo contraditório e uma efetiva ampla defesa, é necessário que as partes possam se valer de todos os meios de prova lícitos e pertinentes à reconstrução dos fatos por elas afirmados. ${ }^{26}$

Todavia, tais entendimentos quanto à derivação do direito à prova não se contrapõem e convivem harmonicamente no ordenamento jurídico, pois, afinal, possuem como ponto de congruência a natureza constitucional do direito à prova. Ressalta-se que entre os princípios constitucionais do processo são perceptíveis e inegáveis as superposições, pois nenhum deles se conceitua por padrões rigorosamente lógicos, mas sim políticos, impossibilitando assim a delimitação precisa de áreas de incidência exclusivas de cada um. ${ }^{27}$

\footnotetext{
${ }^{24}$ Nesse sentido NERY JUNIOR, Princípios do processo civil..., 1999, p. 30.

${ }^{25}$ Nesse sentido LOPES, A prova..., 2002, p. 162. Segundo o autor o direito à prova decorre do devido processo legal, consistindo em aspecto fundamental do direito à ampla defesa. Ainda DINAMARCO, Cândido Rangel. Fundamentos do processo civil moderno. 4. ed. São Paulo: Malheiros, 2001. p. 463-464. Sustenta que o direito à prova é um verdadeiro direito público ou cívico de cada uma das partes, inerente à ação e à defesa. A prova é inerente ao próprio direito ao processo, consistindo em postulado incontornável do acesso a uma ordem jurídica justa. Na doutrina estrangeira CANOTILHO, Estudos..., 2004, p. 169-170. Afirma que o direito constitucional à prova surge, na maior parte das vezes, ou dissolvido nos princípios de direito e processo penais constitucionalmente consagrados (direito de defesa, direito ao contraditório, direito de intervenção no processo, proibição de provas ilícitas) ou associado ao direito e tutela jurisdicional. Ainda TROCKER, Processo civile e costituzione..., 1974, p. 513 e ss.; PATTI, Prove..., 1987, p. 39, nota 2, especialmente quanto às referências bibliográficas.

${ }^{26}$ Nesse sentido BEDAQUE, José Roberto dos Santos. Garantia da amplitude de produção probatória. In TUCCI, José Rogério Cruz. Garantias constitucionais do processo civil. São Paulo: Editora Revista dos Tribunais, 1999. p. 168; TARUFFO, Michele; COMOGLIO, Luigi Paolo; FERRI, Corrado. Lezioni sul processo civile. Bologna: Il Mulino, 1995. p. 513-514. O direito à prova legitimamente obtida ou produzida é um complemento da garantia de defesa, sendo o fundamento prático do contraditório. Cf. TUCCI, Rogério Lauria; TUCCI, José Rogério Cruz e. Constituição de 1988 e processo: regramentos e garantias constitucionais do processo. São Paulo: Editora Saraiva, 1989. p. 68.

${ }^{27}$ DINAMARCO, Instituições..., 2009, v. 1, p. 203. E exemplifica: "Ao sentenciar em desfavor de uma das partes sem ter colhido as provas admissíveis que ela haja regularmente requerido, o juiz viola ao mesmo tempo as garantias do contraditório, da ampla defesa e do devido processo legal.". (grifos do autor).
} 
E aqui o sistema jurídico já sinaliza que a prova não deve ser analisada somente pelo prisma do ônus, ${ }^{28}$ como tradicionalmente é feito, devendo ser tratada como verdadeiro instrumento de solução de controvérsias, com efetiva aptidão para garantir ao titular de um interesse juridicamente protegido a correspondente tutela jurisdicional.

Retornando à discussão doutrinária anteriormente mencionada, necessário firmar a premissa que o direito constitucional à prova no ordenamento jurídico pátrio, majoritariamente, assim como no direito norte-americano, deriva precípua e diretamente da cláusula do devido processo legal, em seu sentido processual. A garantia do devido processo legal, diante de sua amplitude, ${ }^{29}$ insere sob sua abrangência, indubitavelmente, o direito à prova. ${ }^{30}$

Esse entendimento ora fixado confere maior relevância e autonomia ao direito à prova, uma vez que retira o caráter de dependência teórico-conceitual em relação ao direito à ampla defesa e contraditório. ${ }^{31} \mathrm{Na}$ realidade essa relação é inversa, pois o direito à prova existe independentemente do direito à ampla defesa. O contrário é que não corresponde a realidade processual, uma vez que o direito à prova é um dos elementos que estruturam o direito à ampla defesa. Assim, se o direito à prova é elemento estrutural do direito à ampla defesa, ele existe independentemente daquele. Ademais, vem ganhando força na doutrina e sendo objeto de relevantes estudos ${ }^{32} \mathrm{o}$ denominado direito autônomo à prova, evidenciando sua autonomia conceitual.

O direito constitucional à prova pode ser também abstraído da garantia constitucional do acesso à justiça. Nossa Constituição Republicana garante aos cidadãos, indistintamente, o efetivo acesso à ordem jurídica justa, disponibilizando, através do

\footnotetext{
${ }^{28}$ Também no direito espanhol, JUNOY, Joan Picó i. El derecho a la prueba en proceso civil. Barcelona: Bosch, 1986. p. 15-16, há tempos advertia para essa questão: [...] la relación entre las partes y la prueba há merecido la atención de la doctrina, esencialmente, desde el prisma de la 'carga de la prueba'; [...] lo clásico consiste en tratar la prueba como una carga sin apercibirse demasiado de que también constituye un derecho primordial de las partes. [...] el derecho de la prueba, como hemos indicado, se configura como uno de los derechos fundamentales del art. 24 C.E. Nesse sentido PATTI, Prove..., 1987, p. 39.

${ }^{29}$ Sobre a amplitude da cláusula do devido processo legal discorre DINAMARCO, Instituições..., 2009, v. 1, p. 250-253.

${ }^{30}$ Substancialmente nesse sentido Ibid., p. 187.

${ }^{31}$ Nesse sentido LOPES, A prova..., 2002, p. 163. O autor atesta a insuficiência da concepção tradicional de ampla defesa, mostrando que de nada vale garantir às partes o direito de deduzir suas alegações se não lhes for assegurado o de prová-las em juízo.

${ }^{32}$ Nesse sentido a tese de Flávio Luiz Yarshell, intitulada Antecipação da prova sem o requisito da urgência e direito autônomo à prova.
} 
processo, mecanismos destinados a proporcionar a satisfação do direito de cada indivíduo. $^{33}$

A doutrina brasileira vem firmando entendimento no sentido de que a garantia constitucional do acesso à justiça é a síntese e razão existencial de todas as demais garantias constitucionais, explícitas ou implícitas, inclusive a do devido processo legal, uma vez que contém em sua essência conceitual a obrigação do Estado em prestar um serviço jurisdicional cujo resultado final do processo seja efetivo, tanto em âmbito do direito material quanto das próprias garantias constitucionais. ${ }^{34}$

Nessa linha de raciocínio resta evidente que o direito à prova é elemento essencial à satisfação do direito do indivíduo, quando esse não for reconhecido e restituído espontaneamente por aquele que o lesou.

Por fim, o Código de Processo Civil brasileiro em vigência, ao disciplinar o tema probatório, principalmente quanto à admissibilidade dos meios probatórios, harmoniza-se com a Lei Maior, regulamentando o direito à prova de forma específica e em observância ao texto constitucional. ${ }^{35}$

\subsubsection{Natureza do direito à prova}

O direito à prova consiste em verdadeiro direito público subjetivo das partes à produção de provas no bojo do processo civil. ${ }^{36}$ Sua natureza jurídica é idêntica a do direito de ação e de defesa, ou seja, o direito de ser ouvido em juízo.

O direito à prova não significa apenas o direito da parte de poder apresentar ao órgão jurisdicional suas alegações e pretensões, mas também implica real oportunidade de praticar todos os atos processuais lícitos que objetivem influenciar positivamente o

\footnotetext{
${ }^{33}$ Este tema será aprofundado no Título III, seção 3.3.2.1 - Inafastabilidade da jurisdição.

${ }^{34}$ Por todos, DINAMARCO, Instituições..., 2009, v. 1, p. 186.

${ }^{35}$ Nesse sentido Ibid., p. 258.

36 Nesse sentido DINAMARCO, Fundamentos..., 2001, p. 463. Sustenta que o direito à prova é um verdadeiro direito público ou cívico de cada uma das partes.
} 
convencimento do julgador e a formação do provimento jurisdicional definitivo. Nesse diapasão, o day in court implica proporcionar à parte condições efetivas de produzir todas as provas disponíveis e possíveis, visando demonstrar a verdade dos fatos alegados, não consistindo, somente, no direito de ser ouvido em juízo. ${ }^{37}$

Deve-se mencionar aqui a importância da colaboração das partes na reconstrução dos fatos, consistindo essa colaboração em um verdadeiro dever das partes em relação ao Estado-juiz no descobrimento da verdade, uma vez que esses mesmos fatos serão objetos de provimento jurisdicional definitivo.

Em síntese, o direito subjetivo à prova é um direito público, pois tem como sujeito passivo, ou seja, como destinatário, o Estado-Juiz. Este, por sua vez, diante da natureza desse direito, tem o dever de dar efetividade à instrução probatória, o que implica promover a livre iniciativa probatória das partes, a participação e o controle das mesmas em todas as fases probatórias, não adotando medidas que visem limitar ou restringir o exercício do direito a ampla produção de prova. ${ }^{38}$

\subsubsection{Direito das partes à prova e o dever de informação do juiz ${ }^{39}$}

Como afirmado anteriormente, não restam dúvidas quanto à existência em nosso sistema jurídico de um direito constitucional à prova. Isso significa, de um lado, que as partes tem o direito à obtenção e à produção de todas as provas lícitas e moralmente legítimas admissíveis em nosso sistema jurídico. De outro, implica existência de deveres correlatos por parte do magistrado. ${ }^{40}$

Esses deveres decorrem da obrigação que o Estado possui de zelar para que o direito das partes à prova seja efetivado de forma plena e em estreita observância às

\footnotetext{
${ }^{37}$ Nesse sentido GOMES FILHO, Direito à prova..., 1997, p. 83.

${ }^{38}$ Nesse sentido Ibid., p. 85.

${ }^{39} \mathrm{O}$ dever de informação do juiz, ora mencionado, será abordado e detalhado, sob outro enfoque, no Título III, seção 3.2.2.2.

${ }^{40} \mathrm{O}$ mesmo raciocínio foi aplicado, ao tratar do princípio do contraditório e sua dupla destinação, por DINAMARCO, Instituições..., 2009, v. 1, p. 220, item 84.
} 
garantias constitucionais que se coligam a este. Alguns desses deveres estão positivados no Código de Processo Civil pátrio, outros decorrem de interpretação sistemática e teleológica.

O dever que ora se identifica e que merece destaque, por guardar ligação direta com o objeto central deste trabalho, consistindo em um dos seus elementos estruturais, e por ser derivado do direito das partes à prova, refere-se ao dever de informação do juiz. Trata-se, na realidade, não de um dever de prestar informações em âmbitos genéricos, mas de um dever de informação específica quanto à matéria probatória e, principalmente, quanto à distribuição do ônus da prova e suas consequências de ordem processual.

Diante disso, relativamente a esse elemento estrutural da teoria da dinamização, sustenta-se que o juiz tem o dever de informar às partes, diante do caso concreto, que ele poderá, ao proferir a sentença definitiva, aplicar a teoria da dinamização do ônus da prova e, em seguida, utilizar a regra de julgamento pertinente ao ônus objetivo da prova, sempre de forma fundamentada. ${ }^{41}$

Assim, ao exercitar esse específico dever de informar, o Estado-juiz deverá cientificar as partes quanto ao objeto da prova, a quem incumbe produzir as provas essenciais de acordo com a regra rígida e tradicional do ônus da prova, as consequências processuais que poderão advir em caso de omissão ou insuficiência na produção das respectivas provas, o dever das partes em colaborar com o Poder Judiciário na busca da verdade e, ainda, como acima afirmado, que no ato sentencial, caso verifique ser cabível, diante da existência de incertezas quanto à matéria fática, poderá aplicar a teoria da dinamização do ônus da prova.

Ao chegar neste ponto, deverá também informar enfaticamente que, diante da possibilidade de aplicação da dinamização do ônus da prova, as partes deverão produzir todas as provas que lhe são disponíveis e possíveis para o descobrimento da verdade e a completa eliminação de incertezas quanto à matéria fática.

\footnotetext{
${ }^{41}$ Nesse sentido ARENHART, Sérgio Cruz. Ônus da prova e sua modificação no processo civil brasileiro. In NEVES, Daniel Amorim Assumpção. Provas: aspectos atuais do direito probatório. São Paulo: Método, 2009. p. 362. Para o autor, ainda que se trate de regra de julgamento, a modificação do regime de distribuição do ônus probatório pela via judicial, em contraposição à legislativa, deve ser previamente advertida aos sujeitos do processo.
} 
Extremamente relevante registrar, firmando posicionamento sobre a questão, que os princípios constitucionais da ampla defesa e do contraditório estão desde já sendo rigorosamente observados, pois o Estado-juiz está, oportunamente, não só comunicando as partes de todo o procedimento e respectivas consequências da aplicação da teoria da dinamização do ônus da prova como, ainda, proporcionando às partes efetiva oportunidade de amplíssima produção de prova.

Ademais, o direito constitucional à ampla defesa e ao contraditório não pode servir de refúgio às partes que não querem colaborar com o Poder Judiciário no descobrimento da verdade. Não é esse o objetivo dessa garantia fundamental.

Se uma das partes tem em suas mãos uma prova essencial ao descobrimento da verdade e, por mera estratégia processual balizada na regra tradicional e rígida de distribuição do ônus da prova, não a produz e, ao final, essa omissão lhe causa prejuízo diante do resultado da prestação jurisdicional definitiva, não pode o ordenamento jurídico (princípios e regras constitucionais e infraconstitucionais) proteger uma omissão dolosa na busca da verdade em favor da própria parte que, deliberadamente, assim decidiu não agir.

O próprio sistema processual civil combate esse tipo de conduta omissiva ao instituir a regra do artigo 243 do CPC, ${ }^{42}$ estabelecendo a impossibilidade de alguém arguir uma nulidade que deu causa, beneficiando-se, assim, de sua própria torpeza. Isso reflete com perfeição que tipo de processo civil a sociedade almeja: um processo voltado para a ideologia liberal-privatista-individualista, cujas práticas dessa espécie são acobertadas e até mesmo legalizadas, ou um processo publicizado, que busca atingir seus resultados sob os paradigmas da eficácia, da eficiência e da plena justiça.

Apesar de ser objeto de seção própria deste trabalho, ${ }^{43}$ é oportuno antecipar que o momento adequado para que o Estado-juiz exercite esse específico dever de informação é o da audiência preliminar, no procedimento ordinário; da audiência de conciliação, no procedimento sumário e o da primeira audiência de conciliação, em sede de Juizado

\footnotetext{
${ }^{42}$ CPC. Art. 243. Quando a lei prescrever determinada forma, sob pena de nulidade, a decretação desta não pode ser requerida pela parte lhe deu causa.

${ }^{43}$ Cf. seção 3.2.2.2.2 - Momento de cumprimento (do dever de informação) e nota 360.
} 
Especial Cível. Assim, o momento adequado se situa na denominada fase do saneamento do processo, cujas partes já deram início ao contraditório, tendo, regra geral, apresentado suas principais peças: o autor, sua petição inicial e sua réplica, e o requerido, suas peças defensivas. Esses atos jurídicos facilitam o juiz em sua análise, uma vez que estará de posse de elementos fáticos mais consistentes e crivados pelo contraditório, ainda que realizado de forma parcial e superficial.

Ressalta-se, ainda em âmbito antecipátorio, que o não exercício desse dever pelo magistrado na fase do saneamento não gera preclusão pro iudicato, podendo fazê-lo em momento posterior. Todavia, deve o magistrado, para não dar ensejo a indesejáveis atrasos no procedimento, cumprir esse dever de informação antes da audiência de instrução e julgamento.

Caso o magistrado vislumbre, após a produção das provas na audiência de instrução e julgamento, que poderá aplicar a teoria da dinamização do ônus da prova, deverá ainda nesta audiência, comunicar às partes, conforme anteriormente mencionado e, em seguida, permitir, em tempo razoável, que estas se manifestem quanto ao respectivo interesse processual de produção de outras provas, sendo tudo decidido no referido ato processual, sob pena de comprometer a celeridade e, em efeito, a efetividade da tutela jurisdicional.

A inobservância, pelo magistrado, desse dever de informação específica quanto à plausibilidade de aplicar a teoria da dinamização do ônus da prova no ato sentencial e sua efetiva utilização na sentença, como será detalhado à frente, gera nulidade processual, por violação de princípios e garantias de ordem constitucional.

Retornando ao enfrentamento proposto nesta seção, verifica-se que, em breve digressão histórico-evolutiva sobre o tema em análise, a doutrina menos recente era uníssona no sentido de que o juiz não tinha o dever de instruir as partes, de informá-las sobre quais fatos essenciais deveriam produzir prova, bem como qual delas caberia o respectivo ônus. Sua obrigação era simplesmente verificar que fatos não havia sido 
provados para, em seguida, evidenciar qual das partes seria prejudicada diante da incerteza fática. $^{44}$

Entretanto, hodiernamente, a doutrina pátria vem mudando de entendimento, reconhecendo a relevância da disciplina do ônus da prova antes mesmo do julgamento da demanda, bem como reconhecendo ser dever do juiz, na audiência preliminar, informar a cada parte o respectivo ônus da prova, advertindo-as quanto às consequências relativas às incertezas advindas da ausência de provas ou sua insuficiência. Essa evolução tem suporte na necessidade de se conferir maior transparência à conduta judicial, o que deriva da cláusula do due process of law e da garantia do contraditório. ${ }^{45}$

Interessante observar que em tão pouco tempo, num marco histórico dessa natureza - da história da ciência processual - uma mesma geração de juristas brasileiros ${ }^{46}$ tenha logrado evoluir seu pensamento jurídico de forma tão visível, demonstrando a tensão e a dinamicidade da sociedade, do direito e da própria ciência processual. O que antes era inconcebível passa a ser indispensável.

Esta é uma límpida lição de que o processualista da atualidade tem que voltar seu olhar científico-jurídico para a evolução constante e, assim, estar atento para as deficiências do presente, acarretadas pela dinamicidade das relações socioeconômicas da sociedade contemporânea, sem se deixar prender nas amarras conceituais das ideologias do passado, objetivando eliminá-las o quanto antes, cumprindo, dessa forma, com sua finalidade precípua: produzir resultados efetivos e eficientes.

\footnotetext{
${ }^{44}$ Nesse sentido WACH, Vorträge, p. 211 et seq. Apud BUZAID, Alfredo. Do ônus da prova. In Estudos de direito I. São Paulo: Saraiva, 1972. p. 66-67. O próprio Buzaid afirmava, com suporte nas lições de LIEBMAN, que o juiz não deve entrar no exame do ônus da prova na pendência da causa, nem advertir as partes das incertezas da prova, nem, finalmente, do encargo que toca a cada qual: tão só depois de produzidas ou não as provas e de examinadas todas as circunstâncias de fato é que o juiz recebe da lei o critério que há de plasmar o conteúdo de sua decisão.

${ }^{45}$ Substancialmente nesse sentido DINAMARCO, Instituições..., 2009, v. 1, p. 82-83. Afirma, ipsis litteris, ser dever do juiz, na audiência preliminar, informar as partes do ônus que cada uma tem e adverti-las da consequência de eventual omissão. Enfatiza que o processo civil moderno quer muita explicitude do juiz e de suas intenções, que são fatores indispensáveis à efetividade do justo processo. Ainda, ARENHART, Ônus da prova..., 2009, p. 335. Sustenta ser conveniente - ainda que não seja imperativo - que o magistrado assinale às partes, com antecedência, qualquer decisão sua a respeito de eventual modificação dos critérios de imputação deste ônus, a fim de que as partes possam saber, ex ante, sobre quais afirmações de fato devem empenhar-se em produzir.

${ }^{46}$ I.e., de Buzaid (1972) a Dinamarco (2009).
} 
Pode-se concluir, assim, que o direito das partes à prova abrange também, sob o marco característico da complementaridade, o direito de ser informado pelo juiz, de forma exaustiva, diante do caso concreto, quanto às regras de distribuição do ônus da prova e suas consequências, ${ }^{47}$ mormente quanto à plausibilidade de aplicação da teoria da dinamização do ônus da prova no momento do proferimento da sentença.

Isso tem pertinência e aplicabilidade para as regras não positivadas, mesmo que derivem de outras que estejam positivadas, ou seja, mesmo que essa regras integrem o sistema jurídico. ${ }^{48}$ Recorrendo à metodologia exemplificativa, não há no nosso sistema do direito processual civil norma positivada que discipline a aplicação da regra de julgamento - ônus objetivo da prova -, i.e., não há regra legal que estabeleça as consequências do disposto no artigo 333, incisos I e II do CPC.

Em contrapartida a esse direito das partes à mencionada informação, subsiste o dever do magistrado de prestar tais informações de forma detalhada e no momento adequado. Este dever, em sua essência, nada mais é que a face oposta da obrigação que o Estado-juiz possui de zelar para que o direito das partes à prova seja efetivado de forma plena e em estreita observância às garantias constitucionais que se coligam a este direito.

Por fim, não há dúvida que seria melhor para o sistema do direito processual civil, tanto sob o aspecto teórico quanto prático, apesar de sua existência no sistema jurídico por derivação de princípios e garantias constitucionais, que houvesse uma alteração legislativa (lege ferenda), introduzindo expressamente, no parágrafo segundo do artigo 331 do Código de Processo Civil brasileiro, ${ }^{49}$ o dever de informação sob menção.

\footnotetext{
${ }^{47}$ Isso tem pertinência tanto para o regime tradicional e rígido, quanto para o regime contemporâneo e flexível, derivado da aplicação da teoria da dinamização do ônus da prova.

${ }^{48}$ Não se está sustentando a existência de um dever de informar o que está na lei, mas justamente o que não está positivado - artigo $5^{\circ}$, inciso II da CR/88.

${ }^{49}$ Entende-se que na audiência preliminar, antes do juiz determinar as provas a ser produzidas, este tem o dever de informar as partes quanto às regras de distribuição do ônus da prova e suas respectivas consequências, o que se vislumbra fundamental para essas possam decidir o conteúdo e os meios de sua atividade probatória. Eis uma proposta de lege ferenda.
} 


\subsection{PROVA COMO DEVER}

A título de se estabelecer uma desvinculação teórica com as doutrinas clássicas sobre o tema, ${ }^{50}$ principalmente as lições editadas entre o primeiro e o último quartel do século anterior, faz-se necessário estabelecer, $a b$ ovo, a seguinte premissa: as concepções de prova como direito e prova como dever somente encontram respaldo e coerência teórico-jurídica diante de um modelo de processo civil publicizado. ${ }^{51}$

Isso implica, necessariamente, no mínimo, equilibrar a eficácia e os efeitos do princípio dispositivo, em contraposição ao princípio inquisitivo, no bojo do processo civil pátrio. ${ }^{52}$ Caso contrário, correr-se-á o risco de retornar, nesta seara, ao primitivo império do interesse eminentemente privado em âmbito do direito processual civil, impossibilitando a evolução que o tema exige.

Para a mencionada doutrina clássica, a atividade probatória das partes tem uma única fonte motriz: o próprio interesse do indivíduo, derivando desse fator ideológico a tradicional visão da prova como ônus.

Nesta mesma linha de pensamento, a atividade probatória se manifesta exclusivamente como emanação do interesse que cada parte-indivíduo tem no êxito da demanda, como uma necessidade meramente prática, cujo descumprimento geraria para a respectiva parte a derrota na demanda. ${ }^{53}$

\footnotetext{
${ }^{50}$ Essencialmente, ROSENBERG, Leo. La carga de la prueba. 2. ed. Buenos Aires: B de F Ltda., 2002. p. 73-79, e MICHELLI, Gian Antonio. La carga de la prueba. Traducción Santiago Sentís Melendo. BogotáColombia: Editorial Temis S.A., 2004. p. 120-122.

${ }^{51}$ Em sentido contrário ROSENBERG, Ibid., p. 38. Afirma que a lei, no procedimento dominado pelo princípio dispositivo, considera como cumprimento de um dever legal, a apresentação das afirmações necessárias e a produção da prova, e que a atividade das partes, primeiramente a da parte onerada, [...] não é só uma consequência prática para prevenir o perigo da derrota na demanda, ou algo que somente se aconselha às partes, mas uma consequência jurídica. (tradução nossa).

${ }^{52}$ Nesse sentido, significativa a afirmativa de ROSENBERG, Ibid., p. 76, ao estabelecer que um dever da parte frente ao Tribunal somente existe diante de um interesse público, sendo que este somente se pode fundar nos casos em que sem a atividade necessária da parte seria difícil ou impossível falar ou ditar uma resolução.

${ }^{53}$ A lição dos clássicos, dentre eles ROSENBERG, Ibid., p. 74 e 77, é claramente influenciada e, assim, estruturada sob os pilares de um modelo de processo civil liberal-privatista, dominado pelo princípio dispositivo. Sobre a existência de um direito e um dever de provar se opõe frontalmente, sob o argumento do
} 


\subsubsection{Dever de produzir prova}

Compreender a prova sob a concepção de um verdadeiro dever, em âmbito do sistema processual civil, é um dos mais árduos desafios que se possa enfrentar. Essa dificuldade possui raízes históricas profundas, pois sempre se analisou o tema da prova sob a concepção de ônus, visão clássica e tradicional, o que será objeto das próximas seções e, somente em tempos recentes, sob a concepção de um direito constitucional e garantia fundamental, conforme anteriormente exposto. ${ }^{54}$

Uma das grandes virtudes, senão a maior, em conceber a prova como verdadeiro dever das partes é a de colocar em evidência o elemento ético que deve nortear toda a atividade jurisdicional através do processo. Esse elemento ético, atualmente relegado no contexto processual, apresenta-se fundamental quanto às relações processuais originárias de toda a atividade probatória - prova e partes e prova e juiz. ${ }^{55}$

Aqui há que se pontuar a existência de dois deveres diversos, porém umbilicalmente ligados: o dever das partes de produzir provas e o dever das partes de proceder de forma ética no exercício dos atos probatórios.

Ainda dentro do contexto histórico, necessário reiterar que a prova sempre foi fruto de uma concepção liberal-privatista de processo civil. Daí a preferência, justificada e deliberada, em conceber a prova como ônus, como encargo a ser exercitado sempre no interesse da respectiva parte, e tão somente em seu interesse. Abandonam-se, assim, outros paradigmas que deveriam nortear o tema da prova como o da justiça e do interesse no descobrimento da verdade, indubitavelmente mais nobres e legítimos que o simplista e egoísta interesse das partes litigantes.

interesse. Afirma que as partes agem sob um único imperativo, seu próprio interesse em triunfar. Chega a explicitar que "las partes no tienen un derecho a ello", referindo-se ao direito de provar.

54 ROSENBERG, La carga..., 2002, p. 36, afirma que a discussão recorrente na doutrina clássica visando saber se a prova é um dever ou um ônus das partes, somente tem sentido em relação ao ônus subjetivo da prova.

${ }^{55}$ YARSHELL, Antecipação da prova..., 2009, p. 205-206, reconhece a relevância dessa concepção de prova como dever das partes. 
Aliás, essa concepção de prova como ônus a ser realizado pela parte caso ela entenda ser conveniente a ela mesma, caso seja de seu interesse, coloca o poder jurisdicional à mercê de relações eminentemente privadas, desprestigia a própria função jurisdicional, sendo que o Estado-juiz, mesmo percebendo que as partes, apesar da delimitanção do litígio, procuram criar uma verdade ao invés de apresentar a real verdade, não tem, a priori, outro caminho senão o de se satisfazer com esse mero joguete, diante das atuais disposições legais que regem o tema.

Importante registrar que essa visão do processo como jogo vem se desconstituindo, ainda que tardiamente, pois se despertou para o fato de que em um jogo não pode haver dois vencedores e, assim, perde também o poder jurisdicional e a respectiva instituição encarregada de administrar esse poder. Esta instituição não poderia e não pode perder nunca, sob pena de descrédito e falecimento de seus ideais. Quando o instrumento do poder jurisdicional tem como mote a verdade e quando essa é descoberta no bojo do processo, tornam-se vencedores não só aquela parte a quem a verdade assiste, mas principalmente o Poder Judiciário que cumpriu com sua função, prestando um eficiente e eficaz serviço à sociedade. Se o serviço prestado pelo Poder Judiciário tem natureza pública, públicos devem ser os princípios que o norteiam, ou pelo menos a maioria deles, mesmo que o direito material seja disponível.

Nesse caminho pedregoso, surgem assuntos correlatos e igualmente complexos, mas que auxiliam nesta nova concepção da prova como dever. A título meramente de exemplo, é ponto extremamente controverso na doutrina, em âmbito do direito processual civil, a existência de um dever de dizer a verdade. ${ }^{56}$

Contudo, libertando-se da visão eminentemente liberal-privatista, a doutrina pátria vem se posicionando no sentido de existir, no sistema processual civil, um verdadeiro

\footnotetext{
${ }^{56}$ Nesse sentido SOARES, Luso. A responsabilidade processual civil. Coimbra: Almedina, 1987. p. 169. Segundo o autor, ainda persiste controversa a questão de saber se vigora, no processo civil, um próprio e verdadeiro dever geral de verdade: "a questão do dever de dizer a verdade (também muitas vezes designada pela forma negativa de proibição de falsas alegações) é das matérias mais discutidas na ciência processualística" sendo "inúmeros os estudos e as investigações que na doutrina estrangeira abordam o tema do dever de dizer a verdade".
} 
dever de colaboração com o descobrimento da verdade, bem como ainda de expor os fatos em juízo em absoluta conformidade com a verdade. ${ }^{57}$

Ademais, vem ganhando vulto na doutrina, principalmente a estrangeira, o tema pertinente à valoração da atitude das $\operatorname{partes}^{58}$ na condução do processo, em seu aspecto macro e micro, se contrapondo ainda que de forma modesta, à natureza precipuamente dispositiva do processo civil dos países da experiência civil law.

Nesse sentido, todas as vezes que um indivíduo passa à condição de parte no processo, não é somente para fazer uso de direitos, mas também e, consequentemente, para assumir determinados deveres. Desta forma, tanto as partes quanto seus respectivos advogados, uma vez integrantes da relação jurídica processual, na concepção de participantes efetivos, tem o dever processual de conduzir-se com lealdade, probidade e boa-fé. Esse dever, por sua vez, desdobra-se no dever de colaboração na produção da prova, para que o juiz e as próprias partes possam alcançar a verdade.

Ad abundantiam, quando a parte escolhe ir a juízo e aceita, dessa maneira, as regras do instrumento do poder jurisdicional, deve firmar subjetivamente um pacto com a verdade, com a boa-fé e a lealdade na condução de seus atos, em suma, com um proceder ético, despojando-se de interesses precipuamente egoísta-liberais.

Em uma breve digressão histórica, é possível afirmar que prevalece em nossa cultura jurídico-processual um entendimento equivocado, com consequências negativas para o próprio processo e para a sociedade, em relação ao dever das partes de lealdade e boa-fé processuais, principalmente quanto à produção da prova.

\footnotetext{
${ }^{57}$ Nesse sentido OLIVEIRA, Carlos Alberto Alvaro de. Garantia do contraditório. In TUCCI, Garantias constitucionais..., 1999, p. 137. Como adverte o autor, não se pode desconhecer que no processo contemporâneo, "recupera-se assim o valor essencial do diálogo judicial na formação do juízo, fruto da colaboração e cooperação das partes com o órgão judicial e deste com as partes, segundo as regras formais do processo". Ainda, KNIJNIK, Danilo. As (perigosíssimas) doutrinas do "ônus dinâmico da prova" e da "situação de senso comum" como instrumentos para assegurar o acesso à justiça e superar a probatio diabolica. In FUX, Luiz; NERY JUNIOR, Nelson; WAMBIER, Teresa Arruda Alvim (Coordenadores). Processo e constituição: estudos em homenagem ao professor José Carlos Barbosa Moreira. São Paulo: Revista dos Tribunais, 2006. p. 945. Segundo o autor, parece certo que o direito brasileiro tende a configurar, em seu limite máximo, a existência do dever de colaboração e revelação da verdade (art. 14, I, do CPC).

${ }^{58}$ YARSHELL, Antecipação da prova..., 2009, p. 60-65, sustenta não ser incorreto extrair do comportamento das partes, incluindo-se a atividade probatória, verdadeiro argumento de prova.
} 
Essa visão equivocada está engendrada entre nós, seguramente, desde as lusitanas Ordenações Filipinas (início do século XVII), as quais se mantiveram vigentes após a Independência do Brasil, cujo processo era caracterizado pelo princípio dispositivo, impulsionado pelas partes e sem premissas publicistas.

Com a mesma intensidade, a visão sob enfoque foi mantida com a Consolidação das leis do processo civil de 1876, conhecida como Consolidação Ribas por ter sido realizada pelo conselheiro do imperador do Brasil Antonio Joaquim Ribas, com o Regulamento 737, vigente em 1850, que disciplinava somente a "ordem do juízo no processo comercial" e que passou a ser aplicado em todo o processo civil brasileiro somente em 1890, por determinação do primeiro governo republicando do Brasil. Manteve-se também nas Constituições Republicanas de 1891 e 1934, sendo que a primeira permitiu, em face da competência concorrente para legislar sobre o processo civil, a promulgação de Códigos de Processo Estaduais, merecendo destaque os de São Paulo, Pernambuco e da Bahia. Por fim, permaneceu viva durante a vigência do Código de Processo Civil de 1939, cuja exposição de motivos foi redigida pelo Ministro da Justiça Francisco Campos e, ainda permanece no atual Código de Processo Civil de 1973, elaborado por Alfredo Buzaid a partir de 1961 e tornado Lei doze anos depois, quando seu criador ocupava o cargo de Ministro da Justiça.

Revendo tempos ainda mais remotos, é possível verificar que as raízes ideológicas desse equivocado proceder foram semeadas pela corrente privatista dominante em toda a sociedade da Europa ocidental da época, após a Prise de la Bastille - Tomada da Bastilha, em 14 de julho de 1789, acontecimento que se tornou símbolo da Revolução Francesa e cujos ideais libertários de "liberdade, igualdade e fraternidade", desaguaram enfaticamente nas ciências humanas, inclusive no direito.

Umas das maiores expressões daquele antigo e ultrapassado ideal de liberdade, da tradicional visão privatista do direito, no bojo do processo civil, é o princípio dispositivo. Vale ressaltar que o princípio dispositivo, na verdade, remonta sua origem em tempos 
ainda mais antigos, i.e., em ordenamentos primitivos, ${ }^{59}$ respeitando-se as diferenças dos contextos sociais e jurídicos existentes nos respectivos marcos temporais.

Em decorrência dessa tradição privatista, que cumpriu seu papel social e ainda ideológico em diferenciados momentos da história, o direito processual civil pátrio e da Europa ocidental ainda resistem em quebrar esse privatismo exacerbado, evoluindo assim para uma mudança de postura metodológica e também empírica.

A complexidade das relações sociais e da própria sociedade exige do direito processual civil uma mudança de entendimento e postura, ainda vigente no processo civil, no sentido de que as partes, no bojo do processo, podem tudo ou quase tudo, inclusive "negligenciar no exercício de faculdades processuais, porque a consequência de suas condutas e omissões seria apenas o perecimento daquelas, as quais são em si mesmas disponíveis.". 60

Não se quer assim extirpar o indispensável princípio dispositivo e substituí-lo integralmente pelo princípio inquisitivo. O que se pretende é um equilíbrio entre ambos no bojo do processo civil, sob os parâmetros do princípio fundamental constitucional do processo civil, o devido processo legal.

Esse equilíbrio entre os mencionados princípios não é algo sui generis em nosso direito processual civil. Vale lembrar que até pouco tempo, como decorrência dos contornos conceituais do princípio dispositivo, ${ }^{61}$ a iniciativa probatória cabia única e exclusivamente às partes, restando ao juiz aguardar inerte a atividade dessas - "um verdadeiro Juiz Pilatos". Nos dias atuais o tema está pacificado de forma diversa. O princípio inquisitivo foi constitucionalmente equilibrado frente ao princípio dispositivo, tendo o juiz iniciativa e efetivos poderes instrutórios. ${ }^{62}$

\footnotetext{
59 Nesse sentido LIEBMAN, Enrico Tullio. Fondamento del principio dispositivo. Rivista di Diritto Processuale, Padova, CEDAM, v. 15, p. 551-565, 1960. p. 564.

${ }^{60}$ DINAMARCO, Instituições..., 2009, v. 1, p. 239.

${ }^{61}$ Cf. LIEBMAN, Fondamento del principio dispositivo, p. 551-565, 1960. O autor discorre ainda sobre a dualidade entre o princípio dispositivo e o inquisitivo em sede de processo civil.

${ }^{62}$ Vide artigo 130 do CPC. Cf. ainda BEDAQUE, José Roberto dos Santos. Poderes instrutórios do juiz. 3. ed. rev., atual. e ampl. São Paulo: Editora Revista dos Tribunais, 2001. p. 86.
} 
$\mathrm{Na}$ busca desse equilíbrio, na releitura desses princípios à luz dos parâmetros constitucionais, é que parece evidente que algumas dessas aparentes "faculdades", podem e devem ser apreendidas como "deveres", e que o sistema jurídico pátrio tem a obrigação de tutelar interesses mais preponderantes para o direito processual, para a jurisdição e para a própria sociedade, que essa privatista, individualista e egoísta disponibilidade, protegida pelo princípio dispositivo. Como prova disso é patente no processo civil uma tendência moderna de reforçar os poderes do juiz, principalmente na condução do procedimento e na descoberta da verdade.

Diante do anteriormente exposto, o presente trabalho evidencia que o tema da prova tem uma forte concepção de dever, principalmente quanto à produção de prova, não possuindo somente a concepção de ônus como usualmente é tratada. É indubitável, dessa forma, a existência de um dever da parte de produzir provas de suas alegações e de fazê-lo dentro de preceitos éticos: lealdade, boa-fé e veracidade.

É uma incongruência prática e uma inconsistência teórica, e até mesmo sistêmicojurídica, o litigante ter o direito de afirmar fatos e, paralelamente, ter a faculdade de não prová-los, i.e., a faculdade de manter-se inerte. ${ }^{63}$ Se a todo direito corresponde um dever ou uma obrigação, nesta seara estar-se-á diante de uma exceção, pois não há, a priori, qualquer dever ou obrigação correspondente ao direito de afirmar do litigante em contraposição ao exercício de produção de prova.

É um verdadeiro nonsense, até mesmo aos olhos do homem comum, ferindo inclusive o bom senso, que o sistema jurídico permita a alguém apresentar fatos ao Poder Judiciário, dando início a um processo, movimentando assim a estrutura Estatal, delimitando a lide, obrigando uma terceira pessoa a vir em juízo se defender, a contratar advogado para essa atividade, o que implica elevados custos e, que esse mesmo sistema jurídico permita que esse mesmo litigante, deliberadamente, injustificadamente, possa manter-se inerte, possa não demonstrar a veracidade dos fatos alegados.

\footnotetext{
${ }^{63} \mathrm{O}$ ambiente do direito processual não pode ser equiparado ao ambiente da política, onde tudo pode ser dito e muito pouco precisa ser provado.
} 
Em contraposição a esse direito de afirmação da parte é possível afirmar haver o dever de produzir provas, de colaborar com o descobrimento da verdade, de proceder com ética.

Em outra vertente, o fato incontestável das partes possuírem um direito à prova de nível constitucional e elevado à garantia fundamental, não coaduna com a transmutação desse direito em mera faculdade - ônus processual, sem consequências outras senão a aplicação de uma regra de julgamento. ${ }^{64}$ Voltando à máxima vigente em nosso sistema jurídico, se a todo direito corresponde um dever, em relação ao anunciado direito das partes à prova, é mais coerente sua correspondência a um dever das partes em produzir provas.

Importante ressaltar que esse dever das partes de produzir provas de suas alegações não descaracteriza, mas, ao revés, fortifica o interesse das mesmas em produzir provas para formar o convencimento do magistrado e obter o bem da vida pretendido, pois conjuga ao interesse, de natureza subjetiva, o fator necessidade de produzir provas, de natureza objetiva.

Diante do que foi anteriormente exposto, pode-se concluir que esse verdadeiro dever das partes de produzir provas encontra expressão e concretude nos princípios processuais da lealdade, boa-fé, moralidade e probidade em seu agir processual e, no dever de colaboração ou cooperação das partes quanto à descoberta da verdade. ${ }^{65} \mathrm{Na}$ essência todos esses elementos se intercomunicam diante de um objeto comum, de um mesmo elemento ético: a veracidade. ${ }^{66}$

Afinal, sem que haja produção de provas pelas partes ou, a partir do momento que esse ato processual seja realizado à margem de um proceder ético delas, não há falar-se em verdade ou estar-se-á distante dela, comprometendo a justiça da tutela jurisdicional e, assim, a própria legitimidade do processo.

\footnotetext{
${ }^{64}$ Substancialmente nesse sentido ARENHART, Ônus da prova..., 2009, p. 322.

65 THEODORO JÚNIOR, Humberto. Abuso dos direitos processuais. BARBOSA MOREIRA, José Carlos. (coord.). Rio de Janeiro: Forense, 2000. p. 120, é enfático ao afirmar que incumbe aos litigantes e seus advogados atuarem com lealdade e boa-fé, expondo os fatos em juízo conforme a verdade. In Abuso de direito processual no ordenamento jurídico brasileiro.

${ }^{66}$ YARSHELL, Antecipação da prova..., 2009, p. 194, sustenta a possibilidade de se cogitar haver um dever de pré-constituir certa prova como desdobramento dos deveres de veracidade e de colaboração.
} 
Não obstante, não se pode omitir que não existe, em nosso ordenamento processual civil, qualquer sanção para o descumprimento desse mencionado dever de produção de prova pelas partes. Por outra via, não se pode confundir, imputando-a ao citado dever, a sanção existente quanto à omissão na produção da prova, pertinente, entretanto, à concepção de prova como ônus, ou seja, a ausência de reconhecimento dos fatos alegados.

Entretanto, diversamente da situação supra mencionada, que versa sobre uma hipótese omissiva, em nosso ordenamento processual civil, relativamente ao proceder de forma ética, a violação do dever de colaboração, do dever de dizer a verdade e dos demais preceitos éticos mencionados, ${ }^{67} \mathrm{em}$ relação a todos os atos processuais, inclusive quanto à produção de provas pelas partes, é sancionada pela lei, ainda que brandamente, sob as vestes da litigância de má-fé e do abuso de direito. ${ }^{68}$ Apesar disso, a jurisprudência pátria é tímida no acolhimento e na aplicação efetiva dessa sanção.

\subsubsection{Fonte legal}

A fonte legal do dever das partes de produção de provas encontra-se em nosso Código de Processo Civil. Este, ao disciplinar as disposições gerais pertinentes às provas, no Capítulo VI, Seção I, mormente em seus artigos 339 a 341, impõe uma série de deveres às partes e ao terceiro, mencionando expressamente o dever de colaboração com o Poder Judiciário no descobrimento da verdade - artigo 339, em conjugação com o artigo 340 e 14 e incisos do mesmo diploma legal.

\footnotetext{
${ }^{67}$ YARSHELL, Antecipação da prova..., 2009, p. 193. O autor preceitua que os deveres de veracidade e de colaboração estão ligados a um princípio de lealdade, que deve inspirar todos os sujeitos da relação jurídica processual.

${ }^{68} \mathrm{Na}$ seara da produção da prova reputa-se litigante de má-fé aquele que alterar a verdade dos fatos (artigo 17, inciso II), violando o dever de expor os fatos em juízo conforme a verdade e de não formular pretensões nem alegar defesa, cientes de que são destituídas de fundamento (artigo 14, incisos I e III), bem como aquele que violar o dever de não produzir provas inúteis ou desnecessárias à declaração ou defesa do direito (artigo 14, inciso IV), todos do CPC.
} 
Ademais, falar em dever de colaboração com o Poder Judiciário no descobrimento da verdade e no dever de expor os fatos em juízo conforme a verdade ${ }^{69}$ - artigo 14, inciso I do CPC - substancialmente, concretamente, somente pode ser feito de uma forma: produzindo prova em juízo.

Além da previsão direta ora mencionada, pode-se ainda abstrair como fonte legal do dever de produção de provas os artigos que impõem uma sanção à violação desse dever. É a hipótese do disposto no artigo 17, inciso II do CPC, que tipifica como litigância de máfé a conduta de alterar a verdade dos fatos, o que só é possível ou pelo exercício do ius postulandi ou pela produção de prova.

Como sustentado anteriormente, o dever de provar possui outro desdobramento, implicando ainda o dever das partes de proceder de forma ética na produção das provas. $\mathrm{O}$ legislador pátrio, nesse particular, procurou valorizar o princípio da probidade, estendendo seu alcance a todos aqueles que intervêm no processo, e não somente às partes ${ }^{70} \mathrm{e}$, ainda, especificando as condutas que tipificam a violação a tal preceito ético e, por fim, culminando sanções de ordem processual.

As violações aos preceitos éticos, no bojo do processo civil, possuem a qualificação jurídica de abuso de direito processual. Como espécie do mencionado gênero, o legislador pátrio, no artigo 17 do citado diploma legal, previu as condutas que tipificam a violação aos preceitos éticos da probidade, lealdade e boa-fé, sob a nomenclatura de litigância de má-fé. $^{71}$

${ }^{69}$ ARENHART, Ônus da prova..., 2009, p. 332, nota 5, e 335-336, afirma que o dever probatório pode ser facilmente extraído, de forma ampla, do teor do artigo 14, inciso I do CPC. Em outra passagem, sustenta que é dever das partes apresentar todas as provas que possuem e que possam ter alguma importância para o processo, como claramente decorre do dever de veracidade estampado no art. 14, inc. I, do CPC (e como ainda seria possível extrair da interpretação a contrario sensu do artigo do art. 14, inc. IV, do mesmo diploma). (grifos do autor). Importante ressaltar a advertência de ROSENBERG, La carga ..., 2002, p. 87, ao afirmar que o dever à verdade não pretende nem pode impedir que se apresentem ao juízo situações duvidosas para sejam decididas, dando lugar à aplicação das normas obre o ônus da prova. (tradução nossa).

${ }^{70}$ THEODORO JÚNIOR, Abuso de direito..., 2000, p. 100, afirma que é sobre os atos das partes e procuradores que mais intensamente recai o princípio da probidade, o qual se traduz na declaração de deveres enunciados no artigo 14 do CPC.

${ }^{71}$ Ibid., p. 113. O autor, sem a preocupação de alcançar a perfeição e a exatidão, definiu abuso direito como sendo os atos de má-fé praticados por quem tenha uma faculdade de agir no curso do processo, mas que dela se utiliza não para seus fins normais, mas para protelar a solução do litígio ou para desviá-la da correta apreciação judicial, embaraçando, assim, o resultado justo da prestação jurisdicional. 
Em efeito, não procede com o dever de lealdade e boa fé - artigo 14, inciso II do CPC - aquela parte que tem total condição de produzir determinada prova e não o faz por estratégia jurídica, calcada no privatista e liberal princípio dispositivo, violando seu dever ético de colaborar com o descobrimento da verdade.

A ampliação desse paradigma, i.e., de que a prova, além da concepção de ônus e de direito, possui ainda a concepção de dever, conduz a uma mudança de postura mais ampla. A parte não pode se apoiar nas regras de produção de prova, principalmente o autor, para apresentar demandas que não objetivem a tutela de um direito lesado. Não pode o processo permitir que suas regras sejam utilizadas como instrumento de estratégia ao invés de instrumento de justiça. A parte tem que se conscientizar que ao lado de seu direito à prova está um dever de fazê-lo, evidentemente na medida das reais possibilidades, o que será mensurado pelo Estado-Juiz.

Vale ressaltar ainda que os princípios constitucionais do processo se harmonizam perfeitamente com a idéia de que a produção de prova pela parte é um dever. Ademais, a concepção de prova como direito e a concepção de prova como dever não impedem, caso seja necessária, a aplicação da regra de julgamento. Estas concepções modernas da prova, na essência, atuam como instrumentos teóricos a evitar as incertezas fáticas.

\subsubsection{Crítica à noção de ônus processual e dever de provar}

A noção de ônus processual é edificada sobre o conceito de conflito intersubjetivo de interesse. ${ }^{72}$ Tal construção doutrinária, por sua vez, é sustentada em bases ideológicas liberais, cujo centro da ciência jurídica consiste no homem em sua concepção individualista.

Lógico assim que a noção de ônus processual somente poderia ser lastreada em um conceito da mesma forma privatista-individualista que é o de interesse intersubjetivo.

\footnotetext{
${ }^{72}$ Nesse sentido IRTI, Natalino. Due saggi sul dovere giuridico: obbligo-onere. Napoli: Jovene, 1973. p. 88.
} 
A partir do momento que se concebe a ciência jurídica, o direito lato sensu e o próprio direito processual civil sob um ângulo mais publicista conclui-se, facilmente, que as partes tem um verdadeiro dever de produzir provas.

Necessário ressaltar que o objetivo aqui é a busca do equilíbrio entre a concepção pública e a concepção privada, sem radicalismos, sob pena de inverter o pêndulo radicalmente para o outro lado, ou seja, para o lado publicista, transformando o direito em instrumento de violência e opressão, como antes visto na história da humanidade. Definitivamente, não é essa a direção a ser tomada, até porque a própria sociedade caminha em outro rumo: o do equilíbrio.

Ademais, esse interesse que edifica a noção de ônus processual é um fenômeno fático e não jurídico. E, indo além na presente crítica, é um fenômeno fático e subjetivo, ou seja, não goza do caráter de universalidade que a ciência tanto preconiza, pois a existência e a intensidade desse interesse variam de indivíduo para indivíduo.

Diferentemente do conceito técnico-jurídico de interesse-processual em âmbito de condição da ação, esse interesse não é identificável, pois o interesse subjetivo de produzir prova varia de indivíduo para indivíduo, em uma infinita conjunção de variáveis.

Ao revés, a ciência jurídica, o direito lato sensu e o próprio direito processual tem um interesse geral, universal e público consistente na busca da verdade, o que se aproxima conceitualmente de um dever de produzir prova, de um dever de colaboração e, ainda, de fazê-lo dentro de preceitos éticos.

Por fim, não se pode perder de vista que a avaliação - feita pelo próprio indivíduo relativa ao ônus, ao agir qualificado como ônus, se desenvolve e se consuma na esfera secreta dele próprio - indivíduo, árbitro do agir e do permanecer inerte. Esse interesse e a respectiva avaliação subjetiva nunca se exteriorizam, somente a ação realizada. ${ }^{73}$

\footnotetext{
${ }^{73}$ Cf. IRTI, Due saggi..., 1973, p. 89.
} 
Em efeito, sua inércia quanto à produção da prova impede qualquer análise externa quanto à ética pertinente ao seu não agir. Daí a impossibilidade de se instituir qualquer sanção de ordem processual para este específico ato omissivo. 


\subsection{PROVA COMO ÔNUS}

O vocábulo ônus, originário do termo latino onus, empregado em vários ramos do conhecimento humano, v.g., jurídico, econômico, político, tem significado comum de encargo, obrigação, responsabilidade. ${ }^{74}$

Todavia, em âmbito jurídico, apresenta significado tecnicamente específico e diverso daquele. Na linguagem jurídica ônus se contrapõe a obrigação. Obrigação é o termo adequado para indicar poder de outrem sobre um sujeito, o qual, justamente em decorrência desse vínculo obrigacional, não tem outra opção de agir, tendo que se sujeitar em detrimento de seus próprios interesses.

Ônus, para a ciência jurídica, significa sujeição, só que no interesse do próprio sujeito onerado. Alguns juristas pátrios discordam que à idéia de ônus corresponda a de sujeição, mesmo que seja em seu próprio interesse, ligando-a a de mera faculdade ou a de risco. $^{75}$

Entretanto, prevalece na doutrina moderna do processo civil, a concepção de sujeição ligada aos interesses próprios do onerado, o que se harmoniza com possíveis e eventuais consequências desfavoráveis que possam advir para ele, instituídas por lei, quando opta por não cumprir com o respectivo ônus.

Assim, quando se menciona à concepção de prova como ônus, estar-se-á referindo à distribuição do encargo de produção de provas e às respectivas consequências de natureza

\footnotetext{
${ }^{74}$ Cf. MICHAELIS. Dicionário escolar língua portuguesa. São Paulo: Melhoramentos, 2002. p. 561.

${ }^{75} \mathrm{Na}$ visão de MIRANDA, Pontes de. Comentários ao código de processo civil. 3. ed. 3. tir. Atual. Sérgio Bermudes. Rio de Janeiro: Forense, 1999. v. 4. p. 253, o termo sujeição diz respeito à hipótese de dever. Afirma que não há sujeição do onerado; ele escolhe entre satisfazer ou não ter a tutela do próprio interesse. BUZAID, Do ônus da prova, 1972, p. 45-78, também no sentido de que à idéia de ônus não corresponde a de sujeição, afirma que correlativa à idéia de ônus é a idéia de risco e não a de subordinação ou sujeição. Ainda nesse sentido, CARNELUTTI, Francesco. Sistema de derecho procesal. Buenos Aires: Uteha, 1944. v. 1. p. 63 et seq., afirma que ônus é uma faculdade cujo exercício é necessário para a fruição de um interesse. Obrigação e ônus têm de comum o elemento formal, consistente no vínculo da vontade, mas diferem no elemento substancial, porquanto, quando há obrigação, o vínculo se impõe para a tutela de um interesse alheio, e para a tutela de um interesse próprio, quando se trata do ônus.
} 
processual, incidentes quando da eventual ausência ou de sua produção insuficiente. Desta forma, ônus da prova está ligado à sujeição e ao risco, não a obrigação. ${ }^{76}$

Essa concepção de prova como ônus será verticalmente analisada no segundo título deste trabalho. Entretanto, algumas outras considerações são devidas neste momento.

É parcialmente correto o conceito de ônus da prova, comumente citado pela doutrina, como sendo o encargo atribuído pela lei a cada uma das partes, de demonstrar a ocorrência dos fatos de seu próprio interesse, visando obter uma decisão favorável a ser proferida no processo. ${ }^{77}$ Em alguns ordenamentos jurídicos, esse encargo pode ser atribuído também por ordem judicial ou por consenso das partes ${ }^{78}$ e o interesse prevalente não é o da parte, de cunho individualista, mas o da verdade.

A doutrina clássica de nosso país concebe o onus probandi e sua distribuição como inseridos em um processo civil de cunho dispositivo, no qual o Estado-juiz não tem o dever de obter e realizar provas ${ }^{79}$ e que predomina, nesse particular, o princípio do interesse da parte em provar suas próprias alegações. Lastreia-se em Chiovenda que, em tempos passados, afirmou que o ônus da prova incumbe à parte que tiver interesse no reconhecimento do fato a ser provado. Enfim, prevalece o princípio do interesse em provar como fator preponderante para a definição do ônus da prova, sendo considerado ainda o propulsor da efetiva participação dos litigantes no processo, dentro da concepção de um processo civil dispositivo. ${ }^{80}$

\footnotetext{
${ }^{76}$ YARSHELL, Antecipação da prova..., 2009, p. 47, afirma que na ótica da regra clássica, i.e., quem alega em juízo determinado fato e dele pretende extrair consequências favoráveis tem o encargo de demonstrar a respectiva veracidade, a prova é vista menos como um direito ou poder da parte, mas como um encargo.

${ }_{77}^{78}$ Essencialmente nesse sentido DINAMARCO, Instituições..., 2009, v. 3, p. 70.

${ }^{78}$ V.g., o direito norte-americano. Cf. DAMASKA, Mirjan R. Il diritto delle prove alla deriva. Bologna: Il Mulino, 2003. p. 109-123. O parágrafo único e incisos do artigo 333 do nosso CPC somente pode ser inserido no contexto da afirmativa supra de forma parcial e com reservas.

${ }^{79}$ Merece ressalva o poder instrutório do juiz, assente em nosso sistema processual civil, como sendo um poder-dever do juiz.

${ }^{80}$ OLIVEIRA, Garantia do contraditório, 1999, p. 138, sobre a falência do princípio dispositivo no processo civil adverte: “... importante ressaltar, contudo que outra é, nos tempos atuais, a concepção dominante sobre a natureza e função do processo civil, principalmente porque a experiência desmentiu a crença na eficiência do trabalho desenvolvido somente pelos participantes do processo. Basta pensar em que a aplicação do princípio dispositivo em sua concepção clássica, impondo exclusiva contribuição das partes no aporte ao processo do material fático, relativiza para além do desejável a apreciação da verdade pelo juiz, forçando-o a se contentar passivamente com a versão necessariamente parcializada trazida tão-só pelos interessados". (transcrição ipsis litteris).
} 
A importância da concepção da prova como ônus e das questões que daí advém são uníssonas, tanto na doutrina pátria quanto na estrangeira, tanto no passado como no presente. Gian Antonio Michelli afirma que "la carga de la prueba realiza dos funciones: la una consistente en dar al juez un criterio, a base del cual decidir en todo caso, a fin de evitar un non liquet; la outra que se concreta en el estímulo a la actividad procesual de las partes". ${ }^{81}$ Para Leo Rosenberg la teoría de la distribución de la carga de la prueba es "la espina dorsal del proceso civil", sendo seu ultimum refugium. ${ }^{82}$ Giuseppe Chiovenda enfatizou que a disciplina do ônus da prova figura entre os problemas vitais do processo. ${ }^{83}$

Em efeito, a grande importância do ônus da prova para o direito e para o processo configura-se no fato de consistir em uma regra que permite ao Estado-juiz proferir uma decisão definitiva, mesmo diante da ausência de convicção deste, a respeito dos fatos alegados. Exatamente nesse sentido a lição de Hernando Devis Echandía ${ }^{84}$ ao afirmar que "La seguridad jurídica, la armonia social, el interés general en que se realicen los fines propios del proceso y la jurisdicción reclaman su existencia”. Abstrai-se, assim, que se pensava o onus probandi somente como regra de julgamento.

Wach, citado por Leo Rosenberg, ressaltando sua importância, afirma que "La distribución adecuada y prudente de la carga de la prueba es una de las instituciones más necesarias o por lo menos más deseables del orden jurídico". ${ }^{85} \mathrm{O}$ acerto dessa afirmativa é incontroverso aos olhos da ciência jurídica.

A distribuição do onus probandi exerce influência direta no resultado das demandas ajuizadas e, consequentemente, no resultado prático-fático na vida dos cidadãos que pretendem ir ou efetivamente vão ao encontro da justiça, por intermédio do Poder Judiciário.

Desde o último quartel do século passado até os presentes dias, o tema sob enfoque tem ampliado suas dimensões teóricas pelas mãos da doutrina estrangeira, que vem

\footnotetext{
${ }^{81}$ In La carga..., 2004, p. 100.

${ }^{82}$ In La carga..., 2002, p. 80 e 84.

${ }^{83}$ In Instituições de direito processual civil. 2. ed. São Paulo: Edição Saraiva, 1965. v. 2. p. 375.

${ }^{84}$ In Teoría general de la prueba judicial. 5. ed. Buenos Aires: Víctor P. de Zavalía Editor, 1981. v. 1. p. 451.

${ }^{85}$ In ROSENBERG, op. cit., p. 85 . (nota 50).
} 
demonstrando a importância do ônus da prova e sua distribuição diante do direito constitucional à prova e dos direitos fundamentais do homem. ${ }^{86}$

É inegável diante dessa nova dimensão teórica que o ônus da prova e sua distribuição, i.e., a justa medida da distribuição do ônus da prova, são fundamentais para a concretização de direitos, liberdades e garantias. ${ }^{87}$

${ }^{86}$ CANOTILHO, Estudos sobre direitos..., 2004, p. 169 e 171, afirma que a ausência de estudos sobre o direito constitucional à prova significa também a inexistência de problematização jurídico-constitucional relativa a categorias jurídicas tão importantes como a do ônus da prova. Cita, corroborando sua assertiva, a jurisprudência norte-americana que confirma haver uma insuficiência metódica quanto à distribution of the risk of non persuasion or burden of proof in proceeding involving Basic Constitutional Rights. O autor defende a existência de um verdadeiro direito constitucional do ônus da prova. Nesse viés ainda as obras KAZAZI, Mojtaba. Burden of proof and related issues. The Hague-London-Boston: Kluwer Law International, 1996 e KOKOTT, Juliane. The burden of proof in comparative and international human rights law (civil and common law approaches with special reference to the american and german legal system). The Hague-London-Boston: Kluwer Law International, 1998.

${ }^{87}$ Substancialmente nesse sentido CANOTILHO, op. cit., p. 175. (nota 21). O autor vai além e afirma que a medida justa da distribuição do ônus da prova é fundamental para a garantia de um direito, devendo-se evitar teorias abstratas e apriorísticas, como a de Rosenberg, e, assim, impondo-se soluções probatórias não aniquiladoras da própria concretização de direitos, liberdades e garantias. 


\section{DOGMA DO ÔNUS DA PROVA}

\subsection{DOGMA DO ONUS PROBANDI NA MODERNIDADE}

\subsubsection{Primeiras linhas}

O presente título tem como proposta inicial analisar o dogma milenar do ônus da prova que, após vencer as barreiras do tempo, as influências e imposições culturais advindas das guerras (vitórias e derrotas) entre os povos antigos, a escuridão cultural em determinadas fases da civilização humana e, ao revés, fases de grande produção intelectual como a do renascimento e do iluminismo, passando por regimes políticos e sistemas de governo de toda ordem, chegou aos nossos dias ainda guardando extrema relevância no cenário jurídico, não somente pátrio, como em todos os sistemas jurídicos originários do direito romano-germânico (civil law) e do direito anglo-americano (common law), ${ }^{88}$ observadas as devidas peculiaridades de cada sistema sobre o tema. ${ }^{89}$

${ }^{88}$ Exemplo da relevância do tema em âmbito mundial se expressa nas discussões e respectivas pesquisas contemporâneas no que diz respeito à unificação e aplicação de regras relativas ao ônus da prova na Comunidade Européia. Cf. TARUFFO, Michele. Poteri probatori delle parti e del giudice in Europa. In CONVEGNO NAZIONALE, 25, 2005, Cagliari. Le prove nel processo civile: quaderni dell associazione fra gli studiosi del processo civile. Milano: Giuffrè, 2007. p. 53-90; BIAVATI, Paolo. Il diritto delle prove nel quadro normativo dell unione europea. In Ibid., p. 91-125; CAPONI, Remo. Note in tema di poteri probatori delle parti e del giudice nel processo civile tedesco dopo la riforma del 2001. In Ibid., p. 265-301; KOKOTT, The burden of proof..., 1998, p. 09-236.

${ }^{89}$ KOKOTT, Ibid, p. 09-10 e 14, ao realizar uma análise comparativa entre o sistema legal americano e o alemão, apresenta com clareza, a existência de significativas diferenças sobre o tema ônus da prova nos dois sistemas. Afirma que "In American evidence law, the distinction between the two kinds of burdens of proof, first, the burden of going forward with the evidence by producing evidence for the court (subjektive Beweislast) and, second, the risk of non-persuasion of the trier of fact (objektive Beweislast), is much more clearly recognized than in German law. This is partly due to the fact that the American law of evidence developed against the background of a jury system, even though today most cases are decided without a jury. [...] Under American law, as he points out, the distinction is of major importance because the trial judge of the first instance decides only legal questions, whereas factual question are delegated for consideration by the jury. [...] However, German legal scholars often refer to the burden of proof without distinguishing between burden of production and persuasion. Generally the tendency is to put the subjective burden (of production) into the foreground, often overlooking the existence of an objective burden (the risk of non-persuasion). This is the reason why in Germany, the term "burden of proof" has, at times, been used synonymously with the burden of adducing evidence (burden of production, subjective burden of proof). [...] In the American system, the burden of producing evidence (subjective burden of proof) concerns the enforcement of individual rights and operates in a completely different manner than in the German inquisitorial System. At least with regard to adjudicative facts, the judge in the United States is limited to the evidence submitted by 
Não se pretende priorizar a verificação do tema sob um viés estritamente histórico. Contudo, como a história dos dogmas e institutos jurídicos apresenta sua relevância máxima quando ilumina o futuro, dando subsídios potenciais para o esclarecimento e aperfeiçoamento destes, torna-se imprescindível sua visualização.

Mirando nesse objetivo e buscando uma perfeita síntese demonstrativa da evolução histórica do dogma do ônus da prova, mas sem a preocupação com marcos temporais específicos, ${ }^{90}$ secundários neste plano descritivo, é possível afirmar, com lastro precípuo em Michelli, ${ }^{91}$ que houve cinco fases marcantes relativas ao desenvolvimento do dogma do onus probandi.

Na primeira fase, o ônus da prova cabia ao demandado. A ele era devido se defender, sendo colocado desde o início da actio em verdadeira situação de culpado e, assim, cabendo-lhe o dever de se desculpar, provando sua inocência.

A segunda fase foi marcada pela total liberdade do juiz em estabelecer qual das partes deveria produzir a prova em juízo, calcado em regras práticas e de experiência que indicavam qual das partes se encontrava em melhor situação de produzir determinada prova.

A terceira fase foi fortemente marcada pela sedimentação dessas regras de experiência. Surge a idéia de prova contrária, com a finalidade de combater os resultados da prova denominada direta.

Imprescindível mencionar aqui, interrompendo a sequência apresentada, que nas fases anteriormente citadas não se concebe o ônus da prova no sentido técnico-jurídico que se apreende na atualidade. Essas fases, num contexto histórico-temporal, correspondem ao sistema de direito primitivo e ao direito romano clássico, nos quais não havia regras jurídicas sobre o ônus da prova, o que será mais detalhado à frente.

the parties. This renders the burden of proof, including the risk of non-persuasion, more important than it is in the German legal system.”. Cf., ainda, nota 158.

${ }^{90} \mathrm{Cf}$. seção seguinte quanto a marcos temporais.

${ }^{91}$ MICHELLI, La carga..., 2004, p. 3-52. 
$\mathrm{Na}$ quarta fase os dois fenômenos anteriores cedem espaço ao dogma do direito comum no qual a necessitas probandi é considerada, exclusivamente, sob o perfil de atividade probatória individual. Como consequência, as regras de distribuição do ônus da prova se manifestam como regra de prova legal.

Na derradeira fase, a atividade probatória das partes perde sua importância como condição indispensável à obtenção de um resultado favorável. Paralelamente, adquire relevância a objetiva sujeição das partes ao contexto dos resultados probatórios, não somente os dependentes da respectiva atividade probatória, mas também os da atividade instrutória desenvolvida pelo juiz. A partir de então, a regra de distribuição do ônus da prova adquire a natureza jurídica de regra de juízo, uma vez que em primeiro plano se situa a atividade decisória do juiz, quando este não se encontre em condições de fixar, de outra maneira, o conteúdo do próprio decisum. ${ }^{92}$

No sentido de regra de juízo, o dogma do ônus da prova tem por objeto central de investigação a verificação dos instrumentos disponibilizados ao juiz para evitar um pronunciamento alicerçado na dúvida ou para eliminar a omissão quanto a um pronunciamento definitivo. Em outras palavras, o que se almeja solucionar com a instituição de regras de juízo de ônus da prova diz respeito tanto ao dever do juiz de se pronunciar em todos os casos, proibindo-se o non liquet, quanto ao dever de eliminação de pronunciamentos de conteúdos duvidosos. Desta forma, resta claro que o problema do dogma do ônus da prova no processo civil espelha um dos aspectos essenciais da função jurisdicional. $^{93}$

Em efeito, a essência e o valor das normas sobre o ônus da prova consistem justamente na instrução que conferem ao juiz acerca do conteúdo da sentença que deve pronunciar. Tais regras indicam, pois, o modo de se chegar a uma decisão, apesar das incertezas relativas às circunstâncias fáticas relevantes ao deslinde da demanda. Isso, por sua vez, mostra que o juiz deve decidir sobre o ônus da prova somente no final do processo, depois da produção de toda a prova pelas partes e o encerramento desta fase

\footnotetext{
92 Nesse sentido ROSENBERG, La carga..., 2002, p. 37. Afirma ser certo que o problema do ônus da prova somente se apresenta quando a prova não foi produzida. (tradução nossa).

${ }^{93}$ Nesse sentido MICHELLI, La carga..., 2004, p. 11.
} 
procedimental e, ainda, após a detida análise das circunstâncias fáticas eventualmente não demonstradas. $^{94}$

Insta ressaltar, desde já, que em caso de existência de incertezas quanto à matéria fática, o conteúdo do decisum a se proferido pelo juiz não terá por sustentação o resultado do contexto probatório, e sim a própria regra de julgamento. Esse resultado negativo será, na essência, causa da aplicação da regra de julgamento.

Desta forma, as regras sobre o ônus da prova somente são aplicáveis quando uma questão de fato discutida e importante para a existência ou inexistência da relação jurídica litigiosa, ou seja, para a resolução da demanda, não foi suficientemente esclarecida, advindo daí a respectiva incerteza. ${ }^{95}$

Em relação à eventual incerteza quanto à matéria fática, importante registrar que não é correto o juiz tratar a afirmação fática não provada como fato inexistente e/ou cuja verdade não se conseguiu demonstrar como efetivamente inverídico, ${ }^{96}$ o que levaria a decisões inadequadas, além de violar o princípio da livre apreciação da prova em seus contornos científicos atuais. $^{97}$

Não obstante, é comum na doutrina pátria, ao interpretar a regra de juízo, a afirmativa de que toda alegação fática não comprovada nos autos deve ser interpretada pelo julgador como fato inexistente, allegatio et non probatio quase non allegatio,

\footnotetext{
${ }^{94}$ Nesse sentido ROSENBERG, La carga..., 2002, p. 17, 23 e 37. Afirma que somente em caso de incerteza sobre a questão de fato, o juiz precisa de uma instrução quanto ao conteúdo da sentença que deve ditar, e esta instrução é dada pelas normas relativas ao ônus da prova. [...] Assim, o problema do ônus da prova somente se apresenta quando a prova não foi produzida. (tradução nossa).

${ }^{95}$ Nesse sentido ROSENBERG, Ibid., p. 24 e 26 . O autor chama a atenção para o fato de que o juiz não pode tratar suas dúvidas internas sobre a aplicabilidade de uma norma jurídica ou de um conceito jurídico como se fosse dúvida relativa a questão de fato. Para as questões jurídicas não cabe um non liquet e sim a incidência do preceito iura novit curia. As normas relativas ao ônus da prova somente são destinadas a resolver as dúvidas no terreno da questão de fato. (tradução nossa).

${ }^{96}$ Uma coisa é não provar um fato alegado, i.e., sua existência, v.g., que o veículo do autor está danificado na parte traseira. Outra é provar a veracidade da alegação, v.g., em quais circunstâncias e como o respectivo acidente ocorreu. A primeira afirmativa pode ser provada em favor do autor e a segunda em seu desfavor, v.g., se restar provado que a culpa do acidente foi exclusiva do autor, i.e., que a alegação verídica era a do requerido. Em âmbito filosófico o vocábulo verdade é empregado em dois sentidos: para se referir a uma proposição e para se referir a uma realidade. Quanto à proposição, pode ser verdadeira ou falsa. Quanto à realidade, pode ser verdadeira, diferenciando-a de aparente, ilusória, irreal, inexistente. Cf. MORA, José Ferrater. Dicionário de filosofia. 4. ed. São Paulo: Martins Fontes, 2001. p. 699.

${ }^{97}$ Nesse sentido ROSENBERG, op. cit., p. 30-31. (nota 50).
} 
apoiando nesta premissa os julgamentos a ser proferidos diante das incertezas fáticas. ${ }^{98}$ Este entendimento somente é plausível quando se pensa nos efeitos da coisa julgada material relativamente à sentença que foi proferida e motivada com fulcro na regra de juízo.

O dogma do ônus da prova faz parte da teoria da aplicação do direito, da aplicação dos preceitos jurídicos. Todavia, não se pode repetir a confusão oriunda do período da prova legal em relação ao dogma sob enfoque e os sistemas de apreciação da prova. Estes temas, apesar de guardarem proximidade, separam-se por limites claros e fixos. A livre apreciação da prova não dá ao juiz qualquer resposta quanto ao que deve fazer quando os fatos apresentados pelas partes como fundamento de suas afirmações permaneceram incertos.

Essa resposta somente é fornecida pelo ônus da prova. A função da apreciação da prova é a de "ensinar" ao juiz a formar, livremente, sua convicção sobre a verdade ou não das afirmações apresentadas e discutidas pelas partes. O ônus da prova atua quando a livre apreciação da prova não foi eficiente na produção de seus respectivos resultados, i.e., na formação da convicção do juiz..$^{99}$

\subsubsection{Origem}

Não obstante não ser objeto precípuo desta pesquisa, torna-se pertinente uma verificação sobre a origem do dogma do onus probandi.

Em âmbito do direito interno romano será considerado para fins de observação e análise, o período do Direito Clássico Romano, que vigorou a partir dos últimos anos da República $^{100}$ até aproximadamente 284 d.C. e o período do Direito Pós-clássico Romano,

\footnotetext{
${ }^{98}$ Nesse sentido DINAMARCO, Instituições..., 2009, v. 3, p. 81. Cf. seção 2.1.8, onde o tema é detalhado.

${ }^{99}$ Nas palavras de ROSENBERG, La carga..., 2002, p. 82, o domínio do ônus da prova começa onde termina o domínio da livre apreciação da prova; se o juiz atravessou este último sem encontrar a solução, o ônus da prova lhe fornece o que a livre apreciação da prova lhe negou. (tradução nossa).

${ }^{100} \mathrm{O}$ período da República, tomando como base a classificação fundada nas modificações da constituição do Estado Romano, vigorou a partir de 510 a.C. até 27 a.C. Aqui começa o período áureo do direito romano, o
} 
que começa com Diocleciano (284 d.C.) e se encerra com o Direito Justinianeu (527 a 565 d.C.). Não será considerado, propositadamente, o período do Direito Arcaico ou PréClássico, uma vez que o "caráter lendário deste período e a falta de elementos autênticos não permitem uma reconstrução histórica certa". ${ }^{101}$

Imprescindível ainda pontuar os períodos pertinentes ao denominado Direito Processual Civil Romano: a) período das legis actiones, ${ }^{102}$ que inicia com a fundação de Roma (754 a.C.) e subsiste até o fím da República; ${ }^{103}$ b) período per formulas, introduzido pela Lex Aebutia (149-126 a.C.), sendo definitivamente oficializado pela Lex Julia Privatorum (17 a.C.), subsistindo até a época do imperador Diocleciano (285-305 d.C.) $)^{104}$ e; c) o período da extraordinaria cognitio, vigente a partir do principado, com o Imperador Otaviano Augusto (27 a.C.), até os últimos dias do império romano do Ocidente, ${ }^{105}$ tendo, contudo, sofrido profundas modificações.

Os dois primeiros períodos, legis actiones e per formulas, constituem a fase denominada ordo iudiciorum privatorum e o terceiro período constitui a fase denominada cognitio extra ordinem. ${ }^{106}$

do direito clássico. O direito recebe profunda elaboração científica dos jurisconsultos. Depois da consolidação do imperador Adriano (117-138 d.C.), o direito adquire novo impulso pelo fato da administração da justiça ter sido assumida diretamente pelo imperador e seus funcionários (cognitio extra ordinem).

${ }^{101}$ Cf. CORREIA, Alexandre; SCIASCIA, Gaetano. Manual de direito romano. 6. ed. São Paulo: Revista dos Tribunais, 1988. p. 16.

${ }^{102}$ No período das legis actiones havia cinco modalidades principais de ações: manus inectio; pignoris capio (essas duas de "natureza" executiva), sacramentum in rem (essa era a ação geral); iudicis postulatio e a conditio (essas três últimas de "natureza" cognitiva).

${ }^{103}$ Sua extinção ocorreu sob a coroa de Augusto, no Império, século I a.C. Imprescindível registrar que a extinção do período das legis actiones não foi imediata, abrupta. Ao revés, foi paulatina, havendo uma progressiva interpenetração das regras que formavam o processo no período formular, que funcionou, concomitantemente, com as ações da lei, até suplantá-las definitivamente.

${ }^{104} \mathrm{O}$ período formular foi extinto ao tempo do Dominato, com o imperador Diocleciano, na passagem do século III para o IV d.C. Podemos afirmar que o procedimento formular "cai em desuso por primeiro nas províncias, sendo extinto, definitivamente, em 342 d.C., conforme consta do Codex 57.1, na Constituição dos imperadores Constancio e Constante”. Cf. MORAES, José Rubens de. Sociedade e verdade: evolução histórica da prova. 2008. 505 f. Tese (Doutorado em Direito Processual) - Programa de Pós-Graduação em Direito, Faculdade de Direito, Universidade de São Paulo, São Paulo, 2008. p. 161. Do mesmo modo como ocorreu com as legis actiones, sua extinção foi gradual, funcionando concomitantemente com a cognitio extra ordinem.

${ }^{105}$ Nesse sentido TUCCI, José Rogério Cruz e; AZEVEDO, Luiz Carlos. Lições de história do processo civil romano. São Paulo: Revista dos Tribunais, 2001. p. 39 e 138. Afirmam os autores que a cognitio extra ordinem vigorou sob a égide de Justiniano, cuja morte ocorreu em 565 d.C.

106 Não há um marco temporal certo, irrefutável, para registrar a gênese desse período. Inclusive os romanistas trabalham como três hipóteses visando identificá-lo. Alguns sustentam que o sistema da cognitio extra ordinem teve origem na atividade jurisdicional evidenciada na "intervenção esporádica (do princeps) em qualquer fase ou momento processual, ao avocar para o tribunal imperial o litígio previamente submetido 
Ad abundantiam, essa delimitação temporal dos grandes períodos do processo civil romano é apenas convencional, sendo impreciso quando e em que medida cada qual deixou de viger, cedendo passo ao subsequente, pois em determinadas épocas da história de Roma, principalmente no período de evolução de um sistema para o outro, ambos vigoraram concomitantemente. $^{107}$

Assentados tais pontos, será direcionada a atenção à origem do dogma do ônus da prova no período histórico acima delimitado.

É correto afirmar que no período das legis actiones não havia regras pertinentes ao ônus da prova ou, pelo menos, regras que merecessem ser objeto, nesse particular, de análise científica pelos romanistas. ${ }^{108}$

No início do período das legis actiones, i.e., com a fundação de Roma (754 a.C.), o processo possuía um caráter de ritual religioso, pois ainda consagrava procedimentos mais antigos oriundos do denominado sistema primitivo. Neste sistema, as regras probatórias eram marcadas por elementos de natureza ordálica, prevalecendo as provas sobrenaturais, que retiravam qualquer racionalidade das mesmas e, consequentemente, por razões lógicas, tornava-se impossível a existência de regras relativas ao onus probandi.

A passagem desses procedimentos do antigo sistema primitivo ao sistema tipicamente romano da igualdade das partes diante do juiz e da plena liberdade deste na valoração dos meios de prova ocorreu, provavelmente, com a legis actio sacramento in rem. A partir dessa evolução ocorrida durante o próprio período das legis actiones, o juiz,

ao juiz natural, ou até mesmo revendo as decisões daquele". Cf. TUCCI; AZEVEDO, Lições de história do processo..., 2001, p. 138. Para outros, a origem situa-se na praxe judiciária realizada nas províncias, especialmente na província do Egito. Por fim, há aqueles que vêem sua gênese nos remédios complementares de tutela pretoriana, mormente nos interdicta. Assentado restou que a cognitio extra ordinem tornou-se procedimento padrão com o imperador Diocleciano.

${ }^{107}$ Nesse sentido Ibid., p. 40 e 193.

108 Substancialmente nesse sentido BUZAID, Do ônus da prova, 1972, p. 48-49; MORAES, Sociedade e verdade..., 2008, p. 107; KARAM, Munir. Princípio distributivo do ônus da prova na organização judiciária romana. Revista de Processo, Revista dos Tribunais, São Paulo, ano 4, n. 24, p. 89-98, out-dez 1981, p. 9092; PACÍFICO, Luiz Eduardo Boaventura. O ônus da prova no direito processual civil. São Paulo: Editora Revista dos Tribunais, 2000. p. 44-45; PUGLIESE, Giovanni. Regole e direttive sull'onere della prova nel processo romano per formulas. Scritti giuridici in memoria di Piero Calamandrei. Padova, CEDAM, v. 3, p. 577-617, 1958. 
na fase apud iudicem passa a ter discricionariedade para estabelecer qual das partes deveria produzir a prova em juízo, detendo o árbitro privado amplos poderes para valorar não só as provas, mas também a qualidade social e moral das próprias partes, isso com base em regras de experiência e equidade, o que não se alterou no período seguinte ao da legis actiones, ou seja, no período per formulas. ${ }^{109}$

No período formular, segunda fase do ordo iudiciorum privatorum, também não existiam regras sobre o ônus da prova. ${ }^{110}$

Havia duas regras práticas principais, complementares entre si: a) o autor tinha que provar as circunstâncias que serviram de base a sua actio e o réu tinha que provar as circunstâncias que alicerçaram a sua exceptio $\left.^{111} \mathrm{e}, \mathrm{b}\right)$ quem afirmava determinado fato tinha de fazer prova dele e não quem o negasse. Essas eram meras regras práticas, que se formaram diante de dificuldades de se provar, sendo ditadas por critérios de conveniência, em cuja essência se encontrava a experiência dos jurisconsultos romanos. ${ }^{112}$ Com o passar do tempo, se condensaram paulatinamente em regra de direito.

Insta mencionar a obra literária de Aulo Gélio - Noites Áticas (14.2.25) - verba ex oratione M. Catonis $^{113}$ - que, escrevendo sob uma perspectiva histórica, pois viveu sob a

\footnotetext{
${ }^{109}$ Nesse sentido MICHELLI, La carga..., 2004, p. 13-15; MORAES, Sociedade e verdade..., 2008, p. 107; KARAM, Princípio distributivo..., 1981, p. 90-92; PACÍFICO, O ônus da prova..., 2000, p. 44-45. No sistema de prova primitivo, após sua invocação, os deuses viriam em socorro de quem tinha razão. Venceria a demanda, quem deus viesse ajudar.

${ }^{110}$ Nesse sentido LONGO, Giannetto. L`onere della prova nel processo civile romano. Studi in onore di Emilio Betti. Milano: Giuffrè Editore, 1961. v. 3. p. 364.

${ }^{111}$ MICHELLI, op. cit., p. 15 e nota 36 (nota 50), afirma que essas regras práticas que foram transmitidas pela compilação justinianeia como fragmentos de uma formulação geral do ônus da prova estavam alterados, segundo a mais recente crítica, pois restou evidente que o propósito dos compiladores era de adaptar o pensamento daqueles às modificações impostas pela nova concepção do processo. Assim, conforme D. 22, 3, 21, é sintomático o contraste entre a fórmula dubitativa do início do fragmento, como se referisse a um parecer sobre uma questão opinável e discutida e o caráter de máxima geral, que se quer extrair da mesma.

${ }^{112}$ Cf. MICHELLI, Ibid., p. 15-16; KARAM, Princípio distributivo..., 1981, p. 92; KASER, Max. Direito privado romano. Trad. Samuel Rodrigues e Ferdinand Hämmerle. Lisboa: Fundação Calouste Gulbenkian, 1999. p. 456 e 470. BUZAID, Do ônus da prova, 1972, p. 49, analisando o período sob enfoque, afirma que alguns princípios colhidos no Digesto e no Código (Corpus Iuris Civilis), mais precisamente os: a) actore non probante, reus absolvitur; b) probatio incumbit qui dicit, non qui negat; c) in excipiendo reus fit actor $e$ negativa non sunt probanda serviram, por grande lapso temporal, de base para a repartição do ônus da prova. 113 Aulo Gélio, desempenhando a atividade de iudex, encontrava-se diante de um impasse: tinha em suas mãos para julgar um processo cujo autor, pessoa de comprovada idoneidade, cobrava um crédito oriundo de mútuo; do outro lado, o demandado tinha reputação de espertalhão. Nesses casos, o costume exigia que o autor provasse, por documento ou testemunha, a existência da dívida. Contudo este não havia produzido qualquer prova. Gélio então, após suspender o processo, reuniu-se com o seu consilium e expôs o caso ao filósofo Favorino. Queria saber se poderia julgar com base no conhecimento privado ou estava obrigado a
} 
época do Imperador Adriano, ${ }^{114}$ tornou-se uma das principais fontes de informações da fase procedimental in iudicio, principalmente sobre matéria probatória. ${ }^{115}$

No processo civil romano clássico ainda não se podia falar de uma necessitas probandi, uma vez que as regras relativas à distribuição do ônus da prova não tinham valor jurídico, apenas representavam regras de conveniência, ditadas pelo juiz quando da valoração de casos concretos, por obra da jurisprudência e, ainda, pelas escolas retóricas. É muito provável que os clássicos nunca formulassem um princípio geral sobre o ônus da prova, sendo que o princípio necessitas probandi incumbit illi qui agit é de origem pósclássica. ${ }^{116}$

Dois fatores são essenciais para a perfeita compreensão da conclusão que ora se abstrai. O primeiro refere-se ao próprio procedimento do processo civil romano no período per formulas, ou seja, a bipartição de instâncias ou bipartição fásica do procedimento. Havia uma primeira fase, denominada in iure, presidida pelo pretor, magistrado oficial, na qual este formalizava o procedimento, inclusive redigindo a fórmula, até a litis contestatio, termo culminante dessa fase. A segunda etapa do sistema per formulas, denominada apud iudicem, diversamente da anterior, era presidida não mais por um magistrado oficial, mas por um particular, um cidadão romano, que era sorteado ou escolhido pelas próprias partes e pelo próprio pretor. Esse juiz particular era denominado iudex. O iudex, regra geral, não detinha conhecimentos técnico-jurídicos, não obstante, era quem praticava todos os atos instrutórios na causa, era quem iria colher, apreciar, interpretar e valorar a prova produzia

julgar conforme os elementos de convicção constantes do processo. Favorino, invocando antiga opinião de Marco Catão, opina pela condenação do réu que não granjeara estima social. Para Catão, se os litigantes tem a mesma dignidade social e não produziram qualquer prova, deve-se acreditar na versão daquele contra o qual foi formulada a pretensão. Aulo Gélio, por fim, por não estar seguro para proferir sentença com base em um juízo moral, pronunciou um non liquet. Nesse sentido TUCCI; AZEVEDO, Lições de história do processo..., 2001, p. 126-127. Cf. ainda MICHELLI, La carga..., 2004, p. 13-14. Este afirma que essa passagem de Gélio se referia provavelmente a legis actio sacramento in personam ou a uma condictio ou a legis actio per iudicis postulationem, quando se tinha a afirmação do crédito por parte do autor e a negação do débito por parte do demandado. Ainda, PACÍFICO, O ônus da prova..., 2000, p. 45.

114 Adriano (Publius Aelius Traianus Hadrianus - 76-138 d.C.), foi imperador romano no período de 117 a 138 d.C. Pertencente à dinastia dos Antoninos, ordenou ao jurista clássico Sálvio Juliano, expoente da Escola dos Sabinianos, a consolidação do ius honorarium (direito pretoriano), cujo trabalho culminou no Édito Perpétuo - edictum perpetuum (117 d.C.), uma das principais fontes do período clássico, obra-prima da jurisprudência de época republicana. Cf. TUCCI; AZEVEDO, Lições de história do processo..., 2001, p. 3031.

${ }^{115}$ Nesse sentido Ibid., p. 123.

116 Cf. MICHELLI, La carga..., 2004, p. 16; SURGIK, Aloísio. Lineamentos do processo civil romano. Curitiba: Edições Livro é Cultura, 1990. p. 69-70; MORAES, Sociedade e verdade..., 2008, p. 116. 
pelas partes para, em seguida, julgar a demanda, ou seja, proferir a sentença. Desta forma, quanto ao onus probandi, diante da ausência de conhecimentos técnico-jurídicos compatíveis com a função de julgar, as regras de direito (processual) pertinentes à prova eram mitigadas, quando não modificadas ou abandonas pelo iudex, até mesmo pela incidência da regra do livre convencimento do juiz, adotada desde os tempos mais remotos em Roma, com a instituição da legis actio sacramento in rem.

O segundo fator, que guarda nexo de causalidade com o anterior, reside na circunstância de que o iudex, na seara da prova, era profundamente influenciado pela retórica desenvolvida no julgamento, pelos grandes oradores e advogados da época romana. Inclusive há vários registros históricos de que o iudex consultava constantemente obras literárias, v.g., Noites Áticas de Aulo Gélio, ${ }^{117}$ como fonte de conhecimentos gerais e, também, de natureza jurídica.

Agrega-se às razões anteriores, uma outra justificativa a qual se reputa de grande relevância e que, por si só, detém robustez para justificar a conclusão ora evidenciada de que não havia onus probandi, no sistema per formulas, apenas regras de experiência. Consiste essa na possibilidade do iudex - juiz particular -, uma vez encerrada a instrução probatória, ao invés de proferir o julgamento através de sentença, proferir sibi non liquet. Nesse período do direito processual romano, o iudex não era obrigado a julgar definitivamente a causa, podendo escusar-se por intermédio do non liquet, ou seja, quando tivesse dúvida de como julgar ou, com quem estava o direito, poderia, alicerçado na dúvida, abster-se de proferir decisum.

Diante disso, considerando que o instituto do ônus da prova é tido como regra de julgamento $^{118}$ e, considerando que não existia obrigação de julgar, uma vez permitido o

\footnotetext{
${ }^{117}$ O próprio Aulo Gélio relata que "nos primeiros tempos em que fora nomeado iudex pelos pretores, ainda jovem, passou a buscar formação para uma escorreita atuação judicante por meio da leitura de livros, gregos e latinos, que cuidassem da complexa arte do ofício de juiz, tendo se escorado nas obras dos poetas e $a$ rethorum epilogis, ou seja, nos modelos dos discursos, nas perorações dos retores.”. Les nuit attiques. Trad. Maurice Mignon. v. 3. Paris: Garnier, 1934. p. 19. Apud MORAES, Sociedade e verdade..., 2008, p. 115.

${ }^{118}$ Esse é o entendimento dominante nos presentes dias: ônus da prova como regra de julgamento, como última alternativa para o juiz diante da dúvida.
} 
non liquet, ${ }^{119}$ fácil e lógica a conclusão de que não havia um "ônus da prova" propriamente dito no período per formulas. ${ }^{120}$

Havia sim, ad abundantiam, meras regras de experiência quanto à distribuição do ônus de provar. Na realidade, estaria, até mesmo, equivocada a utilização dessa terminologia - ônus da prova -, uma vez que diante da possibilidade de um non liquet, a ausência de cumprimento pela respectiva parte deste "ônus", poderia não acarretar qualquer consequência negativa, qualquer prejuízo à respectiva parte, desclassificando, assim, o próprio termo "ônus" para mera "faculdade", sem qualquer consequência àquela que lhe cabia. $^{121}$

Enfim, regras técnicas e racionais, pertinentes à distribuição do ônus da prova, ainda que insinuadas ou delineadas no período do ordo judiciorum privatorum, apenas encontraram concretude com a atividade judicante dos magistrados 'juristas', o que ocorreu no período seguinte do direito processual civil romano denominado cognitio extra ordinem.

No sistema da cognitio extra ordinem a bipartição de instâncias foi extinta. As instâncias processuais se unificaram. Na conformidade desse sistema, havia somente uma fase, sendo conduzida integralmente por um magistrado oficial, designado pelo Imperador e atuando, ainda que por delegação, em seu nome e vontade: ex autoritate principis. Assim, foi eliminada do sistema a figura do iudex como um juiz privado. Em virtude da

\footnotetext{
${ }^{119}$ O sibi non liquet somente era lícito para o juiz privado, o iudex do período do ordo iudiciorum privatorum, sendo incompatível com a função pública do magistrado, evidenciada com o período da extraordinária cognitio. Pode-se afirmar que o sibi non liquet teve seu fim com o período da cognitio extra ordinem.

${ }^{120}$ MORAES, Sociedade e verdade..., 2008, p. 114 e 115, afirma que a temática da prova deve, portanto, no contexto do ordo, na generalidade dos casos, ser apreciada, de início, sob a luz de sua compartimentalização procedimental específica, apreciada por um personagem de formação não técnica, cujas preocupações com o dimensionamento processual da prova não eram, necessariamente, marcadas pelo viés do pensamento jurídico, pelo simples fato de que para a realização de suas atividades judicantes, não lhe era exigida a formação jurídica própria do magistrado oficial. [...] A prova realizada, apud iudicem, ou seja, diante do iudex, era, pois, muito mais ligada ao universo da atuação performática dos advogados oradores - que se serviam da retórica como discurso organizado, mas ostensivamente voltado para o convencimento emocional dos presentes, inclusive do iudex - que a um mecanismo de caráter técnico-jurídico, preciso e bem elaborado, como, talvez, preferiríamos conceber, conferindo-lhe, anacrônica e equivocadamente, um lugar privilegiado como um provável instrumento jurídico sofisticado pertencente aos quadros da ciência processual romana.

${ }^{121}$ Fala-se em ônus quando o exercício de uma faculdade é posto como condição para obter certa vantagem. Por isso ônus é uma faculdade, cujo exercício é necessário para a consecução de um interesse. Cf. CARNELUTTI, Francesco. Sistema di diritto processuale civile. Padova: Cedam, 1936. v. 1. p. 53 e ss.
} 
extinção da bipartição do iter procedimental a fase instrutória - admissão, produção e valoração da prova - e, ainda, a prolação da sentença, ficou a cargo do magistrado estatal. A atividade jurisdicional passa a ter conotação eminentemente publicista, uma verdadeira prerrogativa pública, um ato de poder, em contraposição a antiga e ultrapassada atuação privada nessa seara.

Sedimentado, portanto, que o dogma do onus probandi como preceito jurídico de caráter geral e, porque não dizer, institucionalizado, teve sua gênese no sistema da extraordinaria cognitio. ${ }^{122}$

\subsubsection{Regra de Juízo}

As doutrinas brasileira e estrangeira praticamente de forma unânime, definem onus probandi objetivo ou ônus objetivo da $\operatorname{prova}^{123}$ como sendo regra de julgamento, destinada, portanto, ao juiz. ${ }^{124}$ Nesse sentido, quase unanimemente, a jurisprudência pátria. $^{125}$

\footnotetext{
122 O processo civil romano da extraordinaria cognitio serviu de modelo para as instituições processuais medievais e posteriores, sendo considerado a primeira forma do processo moderno. Nesse sentido TUCCI; AZEVEDO, Lições de história do processo..., 2001, p. 138; SURGIK, Lineamentos do processo..., 1990, p. 132.

${ }^{123}$ ROSENBERG, La carga..., 2002, p. 32-33, propôs em sua primeira edição de sua clássica obra 'La carga de la prueba' a denominação de 'carga de la certeza'. Posteriormente, expressamente, afirmou não se opor às demais denominações: ônus formal e ônus material da prova; ônus subjetivo e ônus objetivo da prova.

${ }^{124}$ Substancialmente nesse sentido BARBOSA MOREIRA, O juiz e a prova, 1984, p. 181. Segundo o autor o juiz não tem que se preocupar com as regras legais de distribuição do ônus da prova, a não ser no momento de sentenciar. Aí então, verificando que determinado fato não foi provado, ele terá de imputar a alguém as consequências desfavoráveis da falta de prova daquele fato; eis aí para que servem as regras sobre a distribuição do ônus da prova. Ainda NERY JUNIOR, Nelson; NERY, Rosa Maria de Andrade. Código de processo civil comentado. 11. ed. São Paulo: RT, 2010. p. 635; MITIDIERO, Daniel. Colaboração no processo civil: pressupostos sociais, lógicos e éticos. São Paulo: Editora Revista dos Tribunais, 2009. p. 125; PACÍFICO, O ônus..., 2000, p. 131-142; MICHELLI, La carga..., 2004, p. 5.; ROSENBERG, La carga..., 2002, p. 18; PISANI, Lezioni..., 2010, p. 445; COMOGLIO, Luigi Paolo. Le prove civili. $2^{\mathrm{a}}$ ed. Riveduta ed ampliata. Torino: Unione Tipografico-Editrice Torinense, 2004. p. 169-171; CONTE, Le prove..., 2009, p. 55; VERDE, Giovanni. L' onere della prova nel processo civile. Pubblicazioni della Scuola di perfezionamento in diritto civile dell'Università di Camerino. Nápoli: Jovene Editore, 1974. p. 11-53.

${ }_{125}$ STJ. $3^{a}$ Turma. REsp 974994/SP (2007/0182927-7). Rel. Min. Nancy Andrighi. Julgado em 05/06/2008. Publicado DJe em 03/11/2008; STJ. $3^{\text {a }}$ Turma. AgRg nos EDcl no Ag 977795/PR (2007/0269695-9). Rel. Min. Sidnei Beneti. Julgado em 23/09/2008. Publicado DJe em 13/10/2008; STJ. $3^{\text {a }}$ Turma. REsp 949000/ES (2007/0105071-8). Rel. Min. Humberto Gomes de Barros. Julgado em 27/03/2008. Publicado DJe em 23/06/2008. Contra, entendendo ser regra de procedimento: STJ. 4 ${ }^{a}$ Turma. REsp 881651/BA (2006/0194606-6). Rel. Min. Hélio Quaglia Barbosa. Julgado em 10/04/2007. Publicado DJe em 21/05/2007.
} 
É ainda assente nas obras dedicadas ao tema em questão que o aspecto objetivo do ônus da prova guarda maior relevo em detrimento ao aspecto subjetivo, havendo posicionamentos extremados quanto à inexistência deste último. ${ }^{126}$

Essa regra de julgamento ou regra de juízo permite ao Estado-juiz, na fase decisória do processo, mesmo diante da existência de incertezas evidenciadas nos autos, quanto à situação fática alegada pelas partes, proferir provimento definitivo. ${ }^{127}$

Tal regra, na realidade, exerce papel essencial para a legitimidade do sistema jurídico e para a pacificação e vida harmônica na sociedade, ${ }^{128}$ pois é a ela que o Estadojuiz recorre nessas situações de incertezas, provocadas pela produção de prova insuficiente ou pela ausência de produção de prova, evitando o não julgamento, ou seja, o sibi non liquet.

Apesar de não restar expressa no direito processual pátrio, pois a norma do artigo 333 do CPC limita-se a distribuir o ônus da prova e, somente implicitamente, a estipular o risco da ausência do convencimento do juízo, ${ }^{129}$ o princípio que se abstrai da mencionada regra de julgamento é importantíssimo e vital ao sistema jurídico.

\footnotetext{
${ }^{126}$ Substancialmente nesse sentido MIRANDA, Comentários ao Código..., 1999, v. 4, p. 270-271. Afirma o autor que o ônus da prova é objetivo, não subjetivo. Como partes, sujeitos da relação jurídica processual, todos os figurantes hão de provar, inclusive quanto a negações. Uma vez que todos tem de provar, não há discriminação subjetiva do ônus da prova. $\mathrm{O}$ ônus da prova, objetivo, regula a consequência de se não haver produzido prova. Em verdade, as regras sobre as consequências da falta da prova exaurem a teoria do ônus da prova. Se falta prova, é que se tem de pensar em se determinar em quem se carga a prova. O problema da carga ou do ônus da prova é, portanto, o de determinar-se a quem vão as consequências de se não haver provado. Discorda-se da afirmativa ora mencionada. Pontes de Miranda parte do pressuposto que todas as partes tem de provar, inclusive os fatos negativos, concluindo dessa premissa que não há discriminação subjetiva do ônus da prova. Entretanto, além do direito positivado disciplinar de forma diversa, a atribuição das consequências da inércia probatória depende de se saber quem tinha o ônus de fazê-lo. Pode-se até contra-argumentar com base na máxima quem alega tem de provar. Mas se ambas as partes alegarem e não provarem? O juiz irá aplicar as consequências somente ao autor? Essa visão de que todos tem de provar todas as suas alegações não encontra suporte na doutrina e jurisprudência brasileiras.

127 VERDE, L' onere della prova..., 1974, p. 60-61, adverte que somente no âmbito da lógica do positivismo legalista, onde se trabalha no campo das normas, pode-se falar de um mecanismo de auto integração que objetiva eliminar as lacunas do sistema e torná-lo completo. Entretanto, diante de um resultado negativo da instrução probatória, não é possível ao juiz recorrer a critérios de integração. Quanto à lacuna de fato, as coisas são diferentes.

${ }^{128}$ VERDE, Giovanni. Considerazioni sulla regola di giudizio fondata sull onere della prova. Rivista di Diritto Processuale, Padova, CEDAM, v. 27, série 2, p. 438-463, 1972. p. 445, corroborando a afirmação supra, sustenta que a imposição do ônus da prova funciona como consequência de uma escolha de civilidade, proibindo o juiz de dar por existentes fatos para os quais não lhe fora alcançada prova plena e convincente. (tradução nossa).

${ }^{129}$ PATTI, Prove..., 1987, p. 84, apresenta afirmativa semelhante em relação ao artigo 2697 do C.C. Italiano, equivalente ao nosso artigo 333 do CPC.
} 
Vale reiterar que é equivocado o entendimento de que o fato essencial não comprovado nos autos implica interpretá-lo como sendo contrário à realidade e/ou à verdade dos fatos. ${ }^{130}$ Todavia, a incidência do fenômeno da coisa julgada material acaba por equiparar essa interpretação com a que se reputa devida, em âmbito de efeito da sentença, pois, considerando como contrário à realidade do fato alegado ou como fato inverídico, ambos se tornarão imutáveis pelo efeito da coisa julgada material.

Essencialmente, quando o fato alegado não é provado, subsiste para o julgador a dúvida, tanto quanto a sua realidade quanto a sua verdade. A solução é dada pela regra de julgamento. Esta não estabelece uma presunção de inexistência ou inverdade dos fatos não provados. Apenas disciplina como o juiz irá julgar. ${ }^{131}$

A única hipótese em que, no processo civil, pode-se evitar a aplicação da regra de juízo é quando se fizer presente a certeza sobre a existência ou inexistência dos fatos principais da demanda. ${ }^{132}$

A função da regra de juízo - ônus objetivo da prova - é de direcionar o julgamento do magistrado, diante da ausência de certeza quanto à existência-inexistência e/ou veracidade-inverdade dos fatos essenciais alegados pelas partes.

Em decorrência lógico-jurídica, a sua aplicação, indubitavelmente, deverá ocorrer na última fase do processo, desconsiderando a fase executiva (processo sincrético), ou seja, no momento do julgamento da demanda. Em síntese, é uma regra de julgamento e, assim, voltada ao juiz, estabelecendo o conteúdo da fundamentação da sentença de mérito ${ }^{133}$ nas hipóteses de ausência ou insuficiência de prova do fato essencial da demanda. Em outras

\footnotetext{
${ }^{130}$ Cf. nota 96.

131 Cf. seção 2.1 .7 - Livre apreciação da prova, regras de experiência e presunções, onde o tema é aprofundado, bem como seção 2.1.8 - Conteúdo da sentença e nota 211.

${ }^{132}$ Vale ressaltar que na Ciência do Direito, a busca da certeza é restringida por normas estritamente jurídicas que regulamentam integralmente os meios de realização da prova. O elemento de prova - prova material tem sua validade e eficácia adstrita ao meio de realização da mesma. A prova, para ter validade jurídica e, via de conseqüência, eficácia, tem que ser obtida e produzida em estrita observância à lei. A prova obtida e produzida contra legem, mesmo que demonstre, em relação a determinado fato, um conteúdo de certeza flagrante, não possuirá nem validade nem eficácia jurídica.

${ }^{133}$ Cf. seção 2.1.8 - Conteúdo da sentença.
} 
palavras, tal regra estabelece a fórmula ${ }^{134}$ que o juiz deve utilizar ao proferir sentença de mérito baseada em fato incerto. ${ }^{135}$

\subsubsection{Visão crítica}

Não se pode negar que em âmbito do dogma do ônus da prova, a tradição romana foi a mestra dos demais povos e, desde então até os presentes dias, recorre-se aos princípios romanos, uma vez que, a priori, correspondem ao mais próximo de uma visão realista da vida, das exigências de justiça, buscada por todos os povos civilizados. Todavia, por razões estritamente contingentes, é possível que o conceito de ônus da prova tenha sido diferente no espaço e no tempo. ${ }^{136}$

Como exemplo de mudanças em nossa legislação relativamente ao ônus da prova, por razões meramente contingentes, é possível mencionar a regra do artigo $6^{\circ}$, inciso VIII, do Código de Defesa do Consumidor. Objetivou-se nas demandas envolvendo direitos consumeristas, equilibrar a relação entre as partes, em âmbito de produção de prova, quando o juiz entendesse que uma das partes estava em posição de inferioridade relativamente à outra, em condição de hipossuficiência.

Problema de primeira ordem relativo à regra de juízo pode ser verificado quando de sua aplicação, i.e., diante de um julgamento baseado no ônus da prova objetivo. Este, em sua essência, consiste em uma regra sistêmica que permite ao julgador tornar certo, um fato incerto, por ficção jurídica, não através da fundamentação da sentença, mas pela incidência do fenômeno da coisa julgada material. Essa sentença definitiva, cujo conteúdo é lastreado

\footnotetext{
${ }^{134}$ Nesse sentido VERDE, L' onere della prova..., 1974, p. 44-45. Afirma que quando se trata de eliminar a incerteza, a dúvida, a regra de juízo continua a ser a fórmula expressiva que sintetiza o caráter racional do processo e do sistema probatório segundo o qual está modelado.

${ }_{135}$ ARAGÃO, Egas Dirceu Moniz de. Exegese do código de processo civil. Rio de Janeiro: AIDE, 1992. p. 86, ressalta o paradoxo entre a atividade do juiz e a do cientista: [...] se prevalecessem os critérios válidos para a pesquisa científica, o magistrado não poderia julgar enquanto pairasse a menor dúvida a respeito da 'verdade dos fatos', isso, porém, conduziria ao famoso non liquet. Prossegue seu raciocínio concluindo que [...] como a sentença terá de ser pronunciada mesmo que as provas não o convençam, é necessário que algum critério o oriente neste momento. O melhor, sem dúvida, é o que a lei adota em decorrência da aplicação da teoria do ônus da prova.

${ }^{136}$ Nesse sentido MICHELLI, La carga..., 2004, p. 4.
} 
em incertezas, em ausência da verdade, consiste, no limite, em algo tão ou mais danoso que o pronunciamento de non liquet, ${ }^{137}$ sob o prisma fático e, assim social.

É isso que ocorre quando o juiz julga com base no onus probandi objetivo: como ele não chegou a uma conclusão robusta sobre os fatos e, na hipótese de total ausência de provas, à qualquer conclusão, a verdade não foi levada aos autos; a parte, por estratégia, ou seja, deliberadamente, ou por se encontrar em desigualdade perante a outra, permaneceu inerte quanto à produção probatória; o juiz, diante da vedação do non liquet, decide com base na ausência de provas, em outras palavras, decide com suporte em uma técnica ultrapassada, ou seja, a distribuição rígida do onus probandi, que foi adotada por um modelo liberal-privatista, essencialmente individualista, originada no último quartel do século XVIII, no qual se privilegiava interesses de uma única classe social dominante.

Há que se indagar, diante dos escopos da jurisdição, se o Estado cumpre, com efetividade, sua função jurisdicional, ao utilizar essa técnica de julgamento baseada na distribuição rígida. Consegue pacificar a sociedade com técnicas que vão de encontro ao princípio maior do sistema, o da justiça? Óbvio que não.

Por outro lado, resta evidente que não se pode retroagir, e não é essa a intenção, à permissão do non liquet. A vedação ${ }^{138}$ do pronunciamento do sibi non liquet, ${ }^{139}$ além de ser uma técnica de natureza político-jurídica, tem relevante importância em âmbito de manutenção da integridade do sistema jurídico, pois, ao revés, se fosse permitido, as consequências seriam nefastas, comparável à ausência da própria justiça na sociedade, principalmente diante da morosidade de nosso sistema judicial.

\footnotetext{
${ }^{137}$ Ao se cotejar os efeitos do sibi non liquet numa perspectiva temporal atual, com base no ordenamento jurídico de nossos dias, e os efeitos do julgamento baseado no fato incerto, por intermédio da regra de julgamento, é possível concluir que este é mais danoso, quando se vislumbra, após seu trânsito em julgado, a incidência do fenômeno da coisa julgada material. Em síntese, um fato incerto, através da regra de juízo e da incidência dos efeitos da coisa julgada, se tornará imutável.

${ }^{138}$ Vale lembrar que ao iudex romano era permitido deixar de julgar, proferindo o conhecido sibi non liquet, procedendo em consequência, a sua substituição por outro iudex, por ordem do pretor. Nesse sentido SCIALOJA, Vittorio. Procedimiento civil romano: ejercicio y defensa de los derechos. Buenos Aires: Ejea, 1954. p. 252-253; KARAM, Munir. Ônus da prova: noções fundamentais. Revista de Processo, Revista dos Tribunais, São Paulo, ano 5, n. 17, p. 50-60, jan-mar 1980. p. 51.

${ }^{139}$ A expressão latina non liquet é uma abreviatura da frase iuravi mihi non liquere, atque ita iudicatu illo solutus sum, que significa resumidamente "jurei que o caso não estava claro o suficiente e, em consequência, fiquei livre daquele julgamento". MARMELSTEIN, George. O método popperiano aplicado ao direito. Versão preliminar de paper a ser apresentado em curso de doutoramento - Direito, Justiça e Cidadania no século XXI - Universidade de Coimbra, Portugal, janeiro 2009. (em fase de publicação). p. 22.
} 
Ademais, a regra de juízo, se de um lado é um instrumento jurídico que evita o sibi non liquet, do outro, coíbe a possibilidade de arbítrio a que poderia conduzir o próprio sistema, caso deixasse ao juiz, diante de cada caso concreto, a livre eleição na adoção da regra de juízo. ${ }^{140}$

O que se busca, em relação ao dogma do ônus da prova em nossos dias, é aperfeiçoar e implementar meios que se harmonizem com o princípio maior do direito, o da justiça, com a verdade real ou pelo menos a sua exaustiva busca, com os preceitos inerentes à instrumentalidade processual e com o modelo de processo cooperativo.

\subsubsection{Causas e efeitos de incertezas no processo}

Quando os resultados da atividade instrutória restaram insatisfatórios, quando o conteúdo do material probatório restou insuficiente, dando ensejo a incertezas quanto à existência ou inexistência dos fatos alegados, bem como ainda não tendo os sujeitos do processo conseguido reproduzir fidedignamente, na fase judicial, a realidade fática vivenciada outrora e que deu origem à pretensão resistida do autor, no atual estágio científico do direito processual e do próprio desenvolvimento cultural da sociedade, não é permitido ao Estado-juiz abster-se de proferir um provimento jurisdicional definitivo, com respaldo nas incertezas de cunho fático então evidenciadas.

Abre-se parêntesis para analisar e afirmar algumas causas que levam a esse estado de incerteza. É possível reputar a responsabilidade desse estado de incerteza, por um lado, ao Estado, que não propicia aos cidadãos, tanto em âmbito penal, quanto o mais em âmbito civil, meios e instrumentos legais e processuais adequados para reproduzir a realidade fática em juízo.

Quem não conhece um cidadão que teve seu direito lesado e restou impossibilitado de reivindicá-lo por não possuir meios e instrumentos legais hábeis a reproduzir a realidade

\footnotetext{
${ }^{140}$ Nesse sentido MICHELLI, La carga..., 2004, p. 447.
} 
fática no espaço judicializado. Os exemplos são das mais variadas ordens: a) órgãos da administração direta e indireta que não fornecem documentação sobre determinadas situações fáticas pertinentes ao próprio cidadão requerente; a.1) quando o fazem, a barreira burocrática é suficiente para impedir os cidadãos humildes, desprovidos de conhecimento da estrutura administrativa do Estado, de obter o resultado pretendido; b) ausência de meios e instrumentos legais hábeis a obrigar as pessoas jurídicas privadas a fornecer documentação sobre específicas situações fáticas vividas pelo cidadão, sem a qual se torna inviável qualquer demanda judicial. Enfim, o Estado deixa o cidadão, em relações dessa natureza, na condição de total desamparo, mendicância, ainda mais se esse necessitar de assistência judiciária gratuita para reivindicar não o direito lesado, mas, previamente, o direito de receber esses documentos. Outro exemplo gritante é inexistência de estrutura específica de realização de perícias judiciais de todas as ordens e, quando existente, é desprovida de inúmeros recursos necessários para um funcionamento regular, quanto o mais de extrema excelência, como se espera do Estado.

É possível afirmar que isso se dá ainda por responsabilidade de todos os sujeitos do processo: autor, requerido e juiz, bem como do representante do parquet quando atua na condição de fiscal da lei. A rigor e em caráter geral, nenhum fato é passível de ficar acobertado, exceto que haja interesse/dolo ou desídia/culpa para que esse não seja reproduzido em juízo. ${ }^{141}$

O direito processual tem que possuir instrumentos para coibir a possibilidade dessa prática, bem como dotar os sujeitos (autor, requerido e juiz) de meios hábeis a denunciá-la, tornando efetiva a condição jurídica de reproduzir os fatos em juízo. Em efeito, é possível afirmar que o juiz tem a responsabilidade de esgotar todos os meios legais hábeis ${ }^{142}$ a trazer aos autos a realidade fática, bem como suprir eventuais dificuldades das partes nesse particular, sem ferir o princípio da imparcialidade.

\footnotetext{
${ }^{141}$ Os advogados e as próprias partes não seguem fielmente a ética do discurso e da argumentação. Os advogados apresentam ao Juiz somente as informações que interessam a si próprios, pois passam a defender seus honorários sucumbenciais, algumas vezes como fim último de seu munus e, ao mesmo tempo, as partes se omitem dolosa ou culposamente diante dessa conduta indesejada de seus patronos. Diante disso, a atividade decisória judicial fica anos luz atrás da atividade decisória desenvolvida pelos cientistas que colhem diretamente seu material de pesquisa e desenvolvem sua própria metodologia.

${ }^{142}$ A distribuição dinâmica do ônus da prova pode ser considerada um desses meios, ainda que indireto, pois a partir do cumprimento do dever de informação pelo juiz, as partes deverão colaborar com o descobrimento da verdade, no bojo do processo civil, de uma forma mais efetiva.
} 
Não pode o Estado, alicerçado nos argumentos privatísticos insculpidos no princípio dispositivo e na imparcialidade do magistrado, lavar suas mãos deixando de propiciar ao cidadão todos os meios possíveis, todos os instrumentos legais concebíveis, visando reproduzir fidedignamente a realidade fática. Isso não é proteger o autor, ao revés, é proteger o cidadão de bem que, ora pode estar na condição de autor, por ter tido um direito violado, ora pode estar na condição de requerido, sendo demandado por razões diversas (uso político do processo, demandas aventureiras, demandas que tem como pano de fundo sentimentos humanos menos nobres como a autopromoção do autor, vingança, ódio, rancor, ganância etc.). Isso não está distante em nosso cotidiano, ao contrário, faz parte dele: demandas indenizatórias ajuizadas visando coagir o requerido a realizar acordo; denúncias caluniosas visando denegrir a imagem do requerido com o fim de obter vantagem direta ou indireta; demandas de cunho político sem qualquer respaldo no direito positivado vigente etc.

Essa instrumentação legal consiste em um dos aspectos do direito constitucional e fundamental à prova e do amplo acesso à justiça. ${ }^{143}$

\subsubsection{Regra de Conduta}

Ônus subjetivo da prova ${ }^{144}$ é sinônimo de regra de conduta e de regra de procedimento, tanto em parte da doutrina estrangeira, ${ }^{145}$ quanto na doutrina pátria. ${ }^{146}$

${ }^{143}$ BARBOSA MOREIRA. José Carlos. Julgamento e ônus da prova. Temas de direito processual: 2 . série. 2. ed. São Paulo: Saraiva, 1988. p. 74. Ressalta que a regra de juízo não é a única técnica de julgamento que pode se valer o juiz nas hipóteses de incerteza. Outra possibilidade é a de que o juiz decida segundo sua íntima convicção, eventualmente apoiado em critérios de probabilidade ou verossimilhança, à luz das afirmações das partes e do confronto delas com a experiência da vida; ou, ainda, que dê ao litígio desate inspirado em considerações de equidade.

${ }^{144}$ A doutrina clássica afirma que o ônus subjetivo da prova somente é concebível em um procedimento dominado pela máxima dispositiva. Cf. ROSENBERG, La carga..., 2002, p. 46.

${ }^{145}$ Por todos, ROSENBERG, Ibid., p. 34-35.

146 YARSHELL, Antecipação da prova..., 2009, p. 71, é enfático ao afirmar que parece fora de dúvida que aludidas regras dizem respeito à produção da prova e, no contexto das garantias do devido processo legal, do contraditório e da ampla defesa, se caracterizam como verdadeiras regras de conduta. Ainda PACÍFICO, $O$ ônus da prova..., 2000, p. 131-134. 
O ônus objetivo e o ônus subjetivo da prova podem ser considerados partes estruturais que constitui um todo indivisível, i.e., formam o dogma do ônus da prova. Não obstante, há entre ambos expressivas diferenças. Cotejando o ônus objetivo com subjetivo, é possível afirmar que a função e o momento de aplicação de cada um são diferentes.

Outra marcante diferença entre ambos se refere ao destinatário das mencionadas normas sobre o ônus da prova. As regras que estabelecem o ônus subjetivo tem por destinatárias as partes. Já as regras que disciplinam o ônus objetivo da prova tem por destinatário o Estado-juiz. ${ }^{147}$

A função precípua da regra que disciplina o ônus subjetivo da prova é direcionar a conduta das partes no processo, no tocante à produção da prova e, secundariamente, à obtenção da prova.

Quando a norma positivada estabelece que o ônus da prova incumbe ao autor, quanto ao fato constitutivo de seu direito, está disciplinando, também, a conduta da parte autora neste sentido. Diante desta regra, a parte autora tem plena ciência que sua conduta deverá ser direcionada, principalmente, à produção da prova do fato constitutivo de seu direito. É uma norma programática. Em efeito, seu conteúdo não veda a produção de quaisquer outras provas pela respectiva parte, apenas direciona, processualmente analisando, a prova essencial que a parte autora poderá produzir. Caso não atenda ao conteúdo programático dessa norma, não sofrerá consequências diretas oriundas dessa própria norma, mas da outra regra, i.e., do ônus objetivo da prova, regra de julgamento.

Em sequência, quando a norma mencionada disciplina que o ônus da prova incumbe ao requerido, quanto ao fato impeditivo, modificativo ou extintivo do direito do autor, está disciplinando a conduta desta parte, neste sentido. A parte requerida tem, assim, plena ciência que sua conduta deverá ser direcionada, principalmente, à produção da prova de fatos desconstitutivos, lato sensu, do direito do autor, sendo essa a prova essencial que a parte requerida deverá produzir.

\footnotetext{
${ }^{147}$ Nesse sentido YARSHELL, Antecipação da prova..., 2009, p. 48 e 49. Afirma ainda que essa dicotomia, aspecto subjetivo e objetivo, além de gerar dubiedade quanto ao destinatário das respectivas normas, coloca em xeque a própria concepção de prova como ônus.
} 
Dessa forma, é possível concluir que, sob o viés subjetivo, a norma de procedimento especifica quem deve provar no processo e, além disso, o que deve provar, i.e., qual espécie de fato deve ser provado. ${ }^{148}$

Importante observar, nesse passo, o fator interesse ${ }^{149}$ da parte na produção da prova e, paralelamente, como as regras processuais efetivamente direcionam a conduta das partes. Apesar da prova ser um direito constitucional amplo e limitado somente por regras igualmente constitucionais, v.g., vedação da prova ilícita, sua produção sofre limitações de ordem processual. O fator interesse na produção da prova é limitado pela própria regra em questão ao estabelecer que esse interesse deva observar a efetiva necessidade. Isto se apresenta claro quando a norma sob enfoque disciplina a natureza do fato que o autor e o requerido tem o ônus de provar.

Em síntese, é possível concluir que o direito constitucional à prova é amplo, porém processualmente limitado pelo interesse-necessidade na produção da prova pela respectiva parte, através da regra de ônus da prova subjetivo. Em adição à presente afirmativa, confirmando-a, necessário apresentar as regras do artigo 400, incisos I e II; 407, parágrafo único, in fine; artigo 420, parágrafo único e incisos; 426, inciso I e artigo 427 do CPC que permitem ao juiz indeferir as provas consideradas desnecessárias no deslinde da demanda.

Quanto ao momento de incidência do ônus subjetivo, termo mais apropriado que momento de aplicação anteriormente utilizado, não resta dúvida que ocorre com o ajuizamento da demanda pelo autor e, com a citação do requerido, ou seja, em âmbito técnico-jurídico, no exato momento em que as regras processuais passam a gerar efeitos jurídicos em relação às partes. Vale ressaltar, conforme afirmado acima, que em relação ao ônus subjetivo da prova, esta norma apresenta conteúdo programático, tendo, assim, plena

\footnotetext{
148 Nesse sentido DINAMARCO, Instituições..., 2009, v. 3, p. 72-83; LOPES, A prova..., 2002, p. 47; ARENHART, Ônus da prova..., 2009, p. 332.

${ }_{149}$ ROSENBERG, La carga..., 2002, p. 15, focado na concepção de interesse define o ônus subjetivo da prova como sendo o ônus que incumbe a uma parte de subministrar a prova de um fato controvertido, mediante a sua própria atividade, se quer evitar a perda do processo. BARBOSA MOREIRA, Julgamento e ônus da prova, 1988, p. 74, também nesse viés, atém-se à idéia do interesse de provar. Afirma que o sistema parte da premissa, explícita ou implícita, de que o maior interessado em que o juiz se convença da veracidade de um fato é o litigante a quem aproveita o reconhecimento dele como verdadeiro, [...]. O desejo de obter a vitória cria para o litigante a necessidade, antes de mais nada, de pesar os meios de que se poderá valer no trabalho de persuasão, e de esforçar-se, depois, para que tais meios sejam efetivamente utilizados na instrução da causa. (grifos do autor).
} 
eficácia e cumprimento de sua função anunciativa antes mesmo do ajuizamento da demanda.

Restou assentado que quando se fala em ônus subjetivo da prova estar-se-á referindo às partes e à produção de provas pelas mesmas. Cada parte tem o interessenecessidade em demonstrar ao Estado-juiz que os fatos ocorreram da forma como descreveu em sua respectiva peça processual e, via de consequência, que o direito material lhe é devido.

A idéia de ônus subjetivo da prova, na essência, pode ser subdividida em duas vertentes: a) uma relativa ao interesse-necessidade em produzir provas que corroborem suas alegações e, b) uma relativa ao risco de não fazê-lo integralmente ou fazê-lo insuficientemente, ou seja, o risco da prova frustrada. ${ }^{150}$ Esta segunda vertente não se confunde com o ônus objetivo da prova - regra de julgamento, apesar de com ele convergir. Afinal, as consequências negativas desse risco, i.e., a prova frustrada, está ligada à atividade do magistrado. Este assunto, risco da prova frustrada, será aprofundado adiante.

O problema que ora se vislumbra é que a regra que realiza a distribuição desse ônus subjetivo, ou seja, distribui a produção das provas às partes, regra geral, se dá de forma rígida, prévia e em abstrato. A lei é quem define quem tem o interesse-necessidade de produzir essa ou aquela prova e, ao mesmo tempo, quem sofrerá as consequências da prova frustrada.

É possível ressaltar que esse critério rígido, inflexível, prévio e genericamente estabelecido como se todas as hipóteses e eventos da vida pudessem ser ali enquadrados, utilizado pelo legislador pátrio para fixar esse ônus subjetivo já se encontra ultrapassado, desconforme, juridicamente descalibrado ${ }^{151}$ ante as mudanças do direito constitucionalprocessual e da própria sociedade. ${ }^{152}$

\footnotetext{
${ }^{150}$ Cf. nota 163. PATTI, Prove..., 1987, p. 13, compreende a referida vertente como ônus objetivo da prova, pois seria um risco objetivo. Contra, ARENHART, Ônus da prova..., 2009, p. 335.

${ }^{151}$ Termo utilizado em referências às normas de calibração. Cf. FERRAZ JÚNIOR, Tércio Sampaio. Introdução ao estudo do direito: técnica, decisão, dominação. 4. ed. São Paulo: Atlas, 2003. p. 191-197.

${ }^{152} \mathrm{Na}$ distribuição dinâmica do ônus da prova, essa repartição ficaria a cargo do juiz, concorrentemente, com o legislador.
} 
Por fim, insta registrar que a regra do ônus da prova subjetivo é mitigada pelo princípio da aquisição (processual) da prova, uma vez que a prova produzida por uma parte pode, perfeitamente, ser utilizada pelo juiz em benefício da parte ex adversa, ou seja, em favor daquela parte que não a introduziu no processo. ${ }^{153}$ Assim, não há qualquer vinculação, em âmbito valorativo, entre a parte que produziu determinada prova e o seu resultado.

\subsubsection{Nascimento da distinção entre ônus da prova objetivo e subjetivo}

Foi Julius Glaser ${ }^{154}$ quem primeiro vislumbrou e estabeleceu uma distinção sobre o tema ônus da prova, em trabalhos publicados em $1883 .{ }^{155}$ Os juristas daquela época entendiam o ônus da prova como consistindo em uma necessidade da parte de cunho prático, ou seja, provar para vencer. A sanção correspondente a esse ônus baseava-se em perder a demanda.

Os trabalhos de Glaser apresentaram ao mundo jurídico da época a distinção entre ônus formal e ônus material da prova, a qual foi inicialmente utilizada pelos processualistas penais. Contudo, a distinção de Glaser não se mostrou perfeita ao direito processual civil, tendo sido os processualistas civis austríacos os precursores na identificação e apresentação da distinção entre ônus subjetivo e ônus objetivo da prova. ${ }^{156}$

\footnotetext{
${ }^{153}$ Nesse sentido PATTI, Prove..., 1987, p. 13 e 14.

${ }^{154}$ In Handbuch des Strafprozesses. Leipzig, 1883. v. 1, p. 364 e ss. Apud ROSENBERG, La carga ..., 2002, p. 33 e nota 14. Ainda, BUZAID, Do ônus da prova, 1972, p. 65. PATTI, Ibid., p. 14, afirma que a distinção entre ônus da prova subjetivo e objetivo se deve à doutrina austríaca do século passado, sendo prontamente acolhida pela doutrina alemã, recebendo menor quantidade de adeptos na literatura italiana.

${ }^{155}$ Essa foi a tônica dos estudos dos processualistas do direito comum e dos tratadistas alemães e austríacos daquela época. Na visão de ROSENBERG, La carga..., 2002, p. 35 e nota 23, mereceu destaque a obra de Adolph Dieterich Weber, intitulada "Sobre a obrigação de produzir a prova no processo civil", cuja primeira edição foi publicada em 1804, a segunda em 1832 e a terceira em 1845. (tradução nossa).

156 POLLAK, System, v. 2, p. 656; SPERL, Lehrbuch, p. 368 et seq. Apud BUZAID, Do ônus da prova, 1972 , p. 65.
} 
A distinção sob enfoque, ${ }^{157}$ que foi objeto de trabalhos científicos posteriores, mostrou de forma clara que o instituto do ônus da prova pode ser entendido sob duas vertentes: uma relativa à atividade probatória das partes e às consequências dessa inatividade e outra relativa à atividade jurisdicional. A primeira é denominada ônus subjetivo da prova e tem suas fontes conceituais em concepções jurídicas de ordem privada. A segunda, denominada ônus objetivo ou regra de julgamento, é aplicada no momento da prolação da sentença, possuindo natureza de ordem pública. ${ }^{158}$

Reiterando o anteriormente mencionado, é possível afirmar que o fenômeno do ônus da prova apresenta duas faces que se complementam. Apesar disto, são faces que possuem características bem distintas entre si e que apresentam apenas um ponto de congruência, o risco, que será adiante desenvolvido. Ad abundantiam, uma das faces é relativa às partes, de caráter subjetivo e a outra diz respeito à função jurisdicional, de caráter objetivo. $^{159}$

Ambas as faces do dogma do ônus da prova, a face objetiva e a subjetiva, são necessárias e úteis ao todo, à completude do dogma, sendo impossível extrair de uma delas argumentos aptos a combater a outra, isso nos dois sentidos do fenômeno. ${ }^{160}$

Em efeito, o fenômeno jurídico do ônus da prova deve ser visto de uma forma una e contextualizada, como um conjunto de relações interligadas e interdependentes, em

\footnotetext{
${ }^{157}$ ROSENBERG, La carga..., 2002, p. 33, afirma que os conceitos de ônus subjetivo e ônus objetivo da prova são importantes para a compreensão de todo o problema da teoria do ônus da prova.

${ }^{158}$ No direito anglo-americano a terminologia é diversa. Utiliza-se a expressão "burden of producing evidence" ou "burden of going forward with evidence" para se referir àquela parte chamada a produzir a prova de um determinado fato e "burden of persuasion" para se referir àquela parte que tem o ônus de persuadir o órgão judicial e que sofre as consequências da ausência de satisfação do respectivo ônus. Este equivale, portanto, ao ônus objetivo da prova. Normalmente ambos os ônus incumbem a mesma parte e, geralmente à parte autora. Contudo, em algumas hipóteses se leva em consideração qual parte tem um melhor conhecimento dos fatos ou dispõe de um melhor acesso à prova, v.g., a regra que grava o requerido com o ônus de provar o pagamento. Outro critério para estabelecer o ônus da prova consiste na probabilidade de certa situação fática, i.e., quem afirma a existência de um fato menos usual é onerado de tal prova. Cf., ainda, nota 89.

${ }^{159}$ Substancialmente nesse sentido ARENHART, Ônus da prova..., 2009, p. 335; BUZAID, Do ônus da prova, 1972, p. 66. Este enxerga o problema do ônus da prova como sendo um fenômeno de duas faces: uma voltada para os litigantes, indagando-se qual delas há de suportar o risco da prova frustrada; é o aspecto subjetivo; e outra, voltada para o magistrado, a quem deve dar uma regra de julgamento. É o aspecto objetivo. [...] O primeiro constitui uma sanção à inércia, ou à atividade infrutuosa da parte; o segundo, ao contrário, é um imperativo da ordem jurídica, que não permite que o juiz se abstenha de julgar, a pretexto de ser incertos os fatos, porque não provados cumpridamente.

${ }^{160}$ Nesse sentido ROSENBERG, op. cit., p. 34. (nota 50).
} 
relações de causa e efeito: se o interessado não produzir prova para demonstrar a veracidade de suas alegações, o juiz não formará sua convicção quanto a quem diz a verdade e quanto a quem assiste o direito material, assim sendo, como lhe é vedado pronunciar o sibi non liquet, será obrigado a proferir provimento judicial definitivo e, a base fática desse provimento será uma ficção jurídica lastreada em uma consequência de ordem processual àquela parte que não cumpriu com seu ônus de produzir prova.

É possível considerar, ainda, que essas terminologias ônus da prova objetivo e ônus da prova subjetivo induzem ao equívoco, deixando transparecer prima oculi que se referem a dois fenômenos jurídicos autônomos, independentes entre si. Todavia, na realidade, o dogma do ônus da prova é um fenômeno único, que possui dois elementos distintos, duas faces que lhe integram, formando o todo, e que, isoladamente, não subsistem como fenômeno de natureza jurídico-processual. ${ }^{161}$

Demonstração cabal do mencionado equívoco terminológico, em aprofundada reflexão jurídica focada no conceito processual de ônus, se abstrai do sagaz raciocínio a respeito do ônus subjetivo da prova, ao se indagar se, conceitualmente, é concebível a existência de algum ônus que não seja subjetivo. ${ }^{162} 163$

\subsubsection{Risco: elemento comum}

\footnotetext{
${ }^{161}$ Nesse sentido ROSENBERG, La carga..., 2002, p. 60. Afirma que o problema da relação entre a o ônus subjetivo e o ônus objetivo da prova somente pode surgir onde ambos os ônus existem um ao lado do outro. Defende que o ônus subjetivo da prova não pode ter um alcance maior que o ônus objetivo da prova, tão pouco pode ter um alcance menor. (tradução nossa).

${ }^{162}$ Cf. DINAMARCO, Instituições..., 2009, v. 3, p. 82. ROSENBERG, Ibid., p. 42, apresenta afirmativa que se encaixa como resposta. Afirma que é completamente acertada a opinião de que não se pode imaginar o ônus da prova sem a característica de que grave sobre alguém. Porém esse gravame que recai sobre a parte onerada consiste unicamente na rejeição de sua petição fundada em uma norma que deveria ser aplicada, mas que não o será porque não constam suas características definidoras do fato, [...]. Ou seja, não guarda relação com a atividade processual probatória das partes.

${ }^{163}$ Uma parte da doutrina alemã reconhece a natureza de ônus apenas ao ônus da prova subjetivo. Quanto ao ônus da prova objetivo, ainda que a terminologia possa induzir a equívoco, se afirma que não se trata de um "ônus" no sentido técnico, mas de uma regra de juízo, que não requer um determinado comportamento das partes e que se destina ao juiz para tornar possível uma decisão no caso de ausência de convencimento. (tradução nossa). In PATTI, Prove..., 1987, p. 14.
} 
Como anteriormente mencionado, parte da doutrina sustenta que o risco da prova frustrada ou o risco da parte onerada sofrer as consequências da não produção da prova integra o ônus objetivo da prova. Parte defende integrar o ônus subjetivo da prova. ${ }^{164}$ Contudo, vislumbra-se uma outra realidade quanto a esse aspecto.

É possível afirmar, como anteriormente pontuado, que o ônus da prova subjetivo é regra de conduta e que o ônus da prova objetivo é regra de julgamento. Contudo o risco da prova frustrada, na verdade, situa-se em uma esfera limítrofe, congruente entre os dois conceitos, formando uma área comum.

Se para a parte onerada o não cumprimento de uma regra de conduta conduz a uma consequência de ordem processual (julgamento de rejeição de seu pedido/defesa), para o juiz implica, ao usar a regra de julgamento, buscar essa mesma consequência para formar seu convencimento. Por sua vez e, em efeito, essa mesma consequência se tornará causa do provimento judicial final.

Assim, esse elemento comum, o risco, se para uma face do fenômeno, a subjetiva, consiste em consequência, para a outra face, a objetiva, transforma-se em causa.

O risco da prova frustrada, na essência, é o elemento que, umbilicalmente, liga as duas faces do fenômeno do ônus da prova e, ao mesmo tempo, impede e inviabiliza a sua separação no âmbito teórico.

Comprovando cientificamente este enunciado, se o autor não provar os fatos alegados, o juiz irá, ao utilizar a regra de julgamento, julgar improcedente seu pedido. Poderá julgar procedente? Não. ${ }^{165}$

\footnotetext{
${ }^{164}$ Cf. PATTI, Prove..., 1987, p. 13. Discorrendo sobre o artigo 2697, do Código Civil Italiano, afirma que o ônus da prova objetivo ou substancial indica à parte em quais limites se produz o efeito negativo no caso de ausência de esclarecimento da situação de fato. Isso exprime o risco da ausência de produção de prova relativamente a um determinado fato. Conclui ratificando que se compreende que o ônus objetivo da prova indica o risco da ausência de esclarecimento da situação de fato e, assim, da ausência de convencimento do juiz. (tradução nossa). Cf. Ainda nota 150.

${ }^{165}$ Não se pode considerar nesse raciocínio, para essa análise específica, a intervenção dos demais sujeitos do processo, pois, como é sabido, a comprovação dos fatos alegados pode vir para os autos pelas mãos da outra parte, de terceiros ou de ofício, pelo juiz, ante o seu poder instrutório.
} 
Contudo, faz-se necessária a exposição de uma outra visão a respeito do ônus da prova e o risco da prova frustrada.

Como foi afirmado anteriormente, a lei processual civil, ao disciplinar e distribuir o ônus da prova, não estabelece expressamente sua consequência, a respectiva sanção processual, fixando apenas o ônus de agir de uma forma ou de outra quanto à matéria probatória, daí ser denominado por alguns como regra de conduta ou procedimento.

Há quem sustente que essa norma relativa ao ônus da prova, na realidade, não consiste em um verdadeiro e próprio ônus, uma vez que a ausência do cumprimento do comportamento prescrito pela norma, além de não estar expresso, não determina automaticamente a não obtenção do interesse perseguido, pois tanto a demanda quanto a exceção podem ser acolhidas assim mesmo.

Pode-se falar então de um risco da ausência de prova a cargo de uma ou outra parte. Contudo, para a aplicação da respectiva sanção - regra de juízo -, além desse indubitável risco relativo à ausência de prova, imperioso ainda conjugar um outro risco, o relativo à ausência de formação da convicção do juiz. Este último pode ser considerado fator determinante para a aplicação da regra do juízo. O primeiro não, diante do princípio da comunhão das provas, do fato da demanda ser fundada em fatos notórios etc.

Diante disso, quando a parte onerada não cumpre com seu respectivo ônus prescrito pela norma, quando não exerce sua faculdade em âmbito probatório, não significa que sua demanda ou sua defesa será obrigatoriamente rejeitada. Todavia, sua inércia implica um aumento significativo do risco de que essa venha a ser efetivamente rejeitada, tornando-se um evento mais provável que antes.

Na verdade, o risco é um elemento tão presente no tema do ônus da prova que mesmo quando a parte onerada cumpre com seu ônus, ou seja, exerce de forma plena sua faculdade em âmbito probatório, o risco faz-se presente, mesmo que em intensidade atenuada, pois a prova produzida passará pelo crivo valorativo do juiz no processo de formação de seu convencimento a respeito da matéria fática. Indiscutível, aliás, a natureza subjetiva do convencimento do magistrado. 


\subsection{6 Ônus da prova no direito processual civil brasileiro}

No atual Código de Processo Civil brasileiro, instituído pela Lei 5.869 de 11 de janeiro de 1973 , que entrou em vigor em $1^{\circ}$ de janeiro de 1974 , a norma que disciplina o ônus da prova está consignada no artigo 333. Estabelece, de forma rígida, que incumbe ao autor a prova do fato constitutivo do seu direito (inciso I) e, ao réu, a prova da existência de fato impeditivo, modificativo ou extintivo do direito da parte adversa (inciso II).

Depreende-se desta norma expressa, que nosso legislador, ao contrário do que pode parecer prima oculi, não adotou a regra romana affirmanti incumbit probatio, ou seja, quem alega o fato tem o ônus de provar, exclusivamente.

A interpretação correta da regra positivada supra citada confirma que o critério de distribuição do ônus da prova ${ }^{166}$ adotado foi, precipuamente, o da natureza do fato alegado e não o da mera alegação de um fato. ${ }^{167}$ Isso implica afirmar que mesmo se o autor alegasse, hipoteticamente, além do fato constitutivo de seu direito, qualquer outro fato que gerasse impedimento, modificação ou extinção de seu próprio direito, não teria o ônus de prová-lo. Da mesma forma, não geraria modificação da regra geral sobre o ônus da prova, nem o ônus de prová-lo, também na seara hipotética, se o requerido, em sua peça defensiva, alegasse um fato que induzisse a comprovação do fato constitutivo do direito do autor, sem configurar o reconhecimento do fato constitutivo principal inserido na pela inicial. $^{168}$

\footnotetext{
${ }^{166}$ A distribuição adequada e prudente do ônus da prova é uma das instituições mais necessárias ou, ao menos, mais desejáveis do ordenamento jurídico, segundo Wach. (tradução nossa). In ROSENBERG, La carga..., 2002, p. 115.

167 BARBOSA MOREIRA, José Carlos. As presunções e a prova. Temas de direito processual: 1. série. 2. ed. São Paulo: Saraiva, 1988. p. 60, afirma que o ônus da prova é distribuído precisamente em função da posição dos sujeitos, i.e., o critério básico repousa na circunstância de ser autor ou réu, no processo, o sujeito considerado.

${ }^{168}$ Nesse sentido ARENHART, Ônus da prova..., 2009, p. 331.
} 
Na história do dogma do ônus da prova alguns critérios norteadores da distribuição do onus probandi apresentaram maior aceitação doutrinária. Outros, apesar de relevantes, serviram de respaldo e fonte de inspiração para a evolução do próprio dogma. ${ }^{169}$

No direito estrangeiro, cada legislação adotou seu critério em particular, não havendo uma uniformidade em âmbito de direito positivo, mesmo nos países cujo sistema jurídico é originário do direito romano-germânico. ${ }^{170}$ Entretanto, guardam entre si, em decorrência da própria origem, mais pontos de congruência que de dissidência em sede teórica. Não se pode, todavia, dizer o mesmo quanto ao direito anglo-americano, cuja matéria recebe tratamento muito diferenciado, principalmente em face do adversary system. ${ }^{171}$

\subsubsection{Origem do critério adotado}

\footnotetext{
${ }^{169}$ Dentre eles a teoria das normas. Diante dessa, cada parte deve afirmar e provar os pressupostos fáticos da norma que lhe é favorável, isto é, da norma cujo efeito jurídico se resolve em seu proveito. Pressupõe nitidamente, portanto, a separação entre questão de fato e questão de direito, ao predispor que sua regulação decorre da configuração da sintaxe entre o fato e a norma: aquele que pretende lograr o efeito decorrente da aplicação da norma tem correlato o ônus de prova sua premissa menor, qual seja, o fato a ela subjacente. Cf. ROSENBERG, La carga..., 2002, p. 130.

${ }^{170}$ Espanha. Artigo 217 (carga de la prueba), Ley de Enjuiciamiento Civil (01/2000): 2. Corresponde al actor y al demandado reconviniente la carga de probar la certeza de los hechos de los que ordinariamente se desprenda, según las normas jurídicas a ellos aplicables, el efecto jurídico correspondiente a las pretensiones de la demanda y de la reconvención. 3. Incumbe al demandado y al actor reconvenido la carga de probar los hechos que, conforme a las normas que les sean aplicables, impidan, extingan o enerven la eficacia jurídica de los hechos a que se refiere el apartado anterior. 7. Para la aplicación de lo dispuesto en los apartados anteriores de este artículo el tribunal deberá tener presente la disponibilidad y facilidad probatoria que corresponde a cada una de las partes del litígio; França. Código de Processo civil. Título I. Disposiciones preliminares. Capítulo I. Los principios rectores del proceso. Sección IV: La prueba. Artículo 9. Las partes tienen la carga de probar conforme a la ley los hechos necesarios para la estimación de sus pretensiones. Artículo 10. El tribunal podrá acordar de oficio la práctica de todos los actos de prueba que resulten legalmente admisibles. Itália. Código Civil Italiano. Art. 2697. Onere della prova. Chi vuol far valere un diritto in giudizio (Cod. Proc. Civ. 163) deve provare i fatti che ne costituiscono il fondamento (Cod. Proc. Civ. 115). Chi eccepisce l'inefficacia di tali fatti ovvero eccepisce che il diritto si è modificato o estinto deve provare i fatti su cui l'eccezione si fonda. Portugal. Código Civil Português. Art. $342^{\circ}$. 1 . Aquele que invocar um direito cabe fazer a prova dos factos constitutivos do direito alegado. 2. A prova dos factos impeditivos, modificativos ou extintivos do direito invocado compete àquele contra quem a invocação é feita. 3 . Em caso de dúvida, os factos devem ser considerados como constitutivos do direito; Argentina. Código Processual Civil e Comercial da Nação Argentina. Art. 377. Incumbirá la carga de la prueba a la parte que afirme la existencia de un hecho controvertido o de un precepto jurídico que el juiz o el tribunal no tenga el deber de conocer. Cada una de las partes deberá probar el presupuesto de hecho de la norma o normas que invocare como fundamento de su pretensión, defensa o excepción. Si la ley extranjera invocada por alguna de las partes no hubiere sido probada, el juez podrá investigar su existencia, y aplicarla a la relación jurídica material del litigio. Alemanha. O ordenamento alemão não dispõe de normas de caráter geral sobre a distribuição do ônus da prova. Tais normas são deduzidas dos respectivos princípios do conjunto das normas positivas substanciais e da própria estrutura do processo civil. Cf. MICHELLI, La carga..., 2004, p. 49.

${ }^{171}$ Cf. notas 158 e 163.
} 
Uma primeira indagação que comumente surge diz respeito à origem do critério de distribuição do ônus da prova adotado no processo civil brasileiro pelo pertinente Código.

Do final do século XIX até a primeira metade do século XX, o tema do onus probandi ganhou a atenção de renomados estudiosos do continente europeu, principalmente dos italianos e, em menor número, dos alemães. Juristas como Michelli, Chiovenda, Carnelutti, Carlo Furno, Augenti, Gianturco, Betti e Rosenberg, prestaram indiscutível contribuição à ciência do direito, produzindo obras consistentes sobre o ônus da prova que além de influenciar suas próprias gerações, foram capazes de expandir essas influências para as gerações posteriores, tornando-se obras obrigatórias na pesquisa do tema até os presentes dias.

As teorias criadas pelos citados autores quanto à distribuição do ônus da prova ${ }^{172}$ tem por traço comum o fato de ter se estruturado na natureza dos fatos, classificados em constitutivos, impeditivos, extintivos e modificativos ${ }^{173} \mathrm{e}$, consequentemente, ter se utilizado, precipuamente, desse fundamento para distribuir o onus probandi. Firmada essa premissa metodológica, a atenção dos pesquisadores e a discussão central sobre o tema passaram a circundar a enorme dificuldade de definição e distinção entre fatos constitutivos e impeditivos, ${ }^{174}$ a qual sobrevive em nossa época, principalmente em relação às demandas de natureza declaratória negativa.

\footnotetext{
${ }^{172}$ Essas teorias foram expostas, de forma sintética, principalmente em GIANTURCO, Luigi. Brevi note sulla teoria dell onere della prova, anche in raporto alle presunzioni, in generale. In GLÜCK, Federico. Commentario alle Pandette. Livro XXII. Milano: Società Editrice Libraria, 1906. v. 22. p. 366 et seq.; SOARES DE FARIA, Sebastião. Principaes theorias relativas ao onus probandi. 1936. 99f. Dissertação (Provimento de Cátedra - Direito Judiciário Civil) - Faculdade de Direito, Universidade de São Paulo, São Paulo, RT, 1936. p. 37 et seq.; SANTOS, Prova judiciária no cível..., 1970, v. 1, p. 93 et seq.

${ }^{173}$ Afirma ARENHART, Ônus da prova..., 2009, p. 331, sobre a forma de identificar a natureza dos fatos alegados pelas partes, que essa deve ocorrer com base na apreciação da norma a incidir no caso concreto. Assim, serão constitutivos os fatos que compõem o substrato fático da norma que gera o efeito pretendido pelo autor. Valendo o mesmo raciocínio para o requerido e os fatos impeditivos, modificativos e extintivos.

${ }^{174}$ CHIOVENDA, Instituições..., 1965, v. 2, p. 381, atesta a dificuldade em se formular, genericamente, um princípio de repartição do onus probandi, justamente diante da dificuldade de se estabelecer, cientificamente e, portanto, guardando caráter de universalidade, o que é fato constitutivo e o que é fato impeditivo, o que pode ser considerado fato juridicamente autônomo ou simples negação do fato afirmado pelo adversário. Exemplificando essa dificuldade apresenta a seguinte hipótese: se o autor afirma que o réu se obrigou a dar 100, e o réu afirma tê-lo feito por brinquedo, a quem incumbirá o ônus da prova? Terá o autor de provar somente que o réu se obrigou, ou também que se obrigou a sério? Deve-se considerar com fato constitutivo do direito o falar a sério, ou como fato impeditivo o falar por brinquedo? Ainda nesse sentido, ECHANDÍA, Teoría general..., 1981, v. 1, p. 468-469, afirma que um fato pode ser constitutivo para o direito pretendido
} 
Indubitável foi a influência exercida pelo Código Civil Francês de $1804,{ }^{175}$ que em seu artigo 1.315, fixou esse princípio legal, ainda que de forma imprecisa, estabelecendo que quem demandasse a execução de uma obrigação tinha o ônus de prová-la, e quem pretendesse liberar-se de um obrigação deveria provar a sua extinção, inclusive se tal ocorreu por intermédio do pagamento. Em 1865, o Código Civil Italiano adotou esse princípio, em seu artigo 1.312, silenciando-se porém quanto aos fatos impeditivos.

Verifica-se, dessa forma, que as regras pertinentes ao direito obrigacional foram, posteriormente, adotadas como sendo de caráter geral. Eis a gênese. Assim, ao autor incumbia o ônus de provar os fatos que consistissem em fundamento de seu direito e, ao réu o ônus de provar os fatos que consistissem em impedimento, modificação ou extinção da pretensão contrária. A doutrina, em efeito, enveredou no sentido de remontar a máxima romana onus probandi incumbit ei qui dicit, ligando o ônus da prova ao interesse do conteúdo da afirmação. Consequentemente, o autor suportaria as consequências desfavoráveis diante da falta de certeza dos fatos que havia apresentado como suporte de sua demanda. ${ }^{176}$

\subsubsection{Ligação com o direito material}

Não se objetiva revolver a antiga celeuma doutrinária quanto à natureza das normas pertinentes ao ônus da prova, i.e., se de direito material ou de direito processual. ${ }^{177}$ Todavia, a maioria da doutrina afirma que tais normas possuem natureza de direito processual, reconhecendo nessas, contudo, a existência de um conteúdo material, pois os

\footnotetext{
por uma parte e extintivo quanto ao alegado pela outra parte, ao mencionar o exemplo da ação declarativa cuja pretensão pode estar fundada em um fato impeditivo, modificativo ou extintivo. (tradução nossa).

${ }^{175}$ O Código Civil Francês entrou em vigor em 21 de março de 1804 . Em 1807 foi rebatizado "Código Napoleão". Após o Congresso de Viena de 1815, voltou a ser conhecido apenas como "Código Civil". Por um Decreto de 1852, em unânime homenagem ao seu idealizador e artífice, Napoleão I, foi restabelecido o nome oficial de Código Napoleão.

${ }^{176}$ Nesse sentido MICHELLI, La carga..., 2004, p. 281.

${ }^{177}$ ROSENBERG, La carga..., 2002, p. 106, afirma que a questão relativa à posição sistemática do ônus da prova não é somente teórica, tendo consequências práticas eminentes para as questões de direito internacional e intertemporal, para as questões de direito federal com o direito estadual, [...]. Essa controvérsia fica mais latente em países como a Itália onde existem regras de ônus da prova dispostas no Código Civil e no Código de Processo Civil.
} 
fatos que as partes devem provar (fatos constitutivos, impeditivos, modificativos e extintivos) somente podem ser identificados a partir do direito material, ${ }^{178}$ principalmente o civil.

Contudo, de forma sintética, aqueles que sustentam a natureza substancial de tais normas se baseiam, principalmente, na circunstância de que os fatos constitutivos, modificativos, impeditivos ou extintivos, que devem ser provados, são abstraídos e disciplinados por normas de direito material. Já os adeptos à tese da natureza processual, afirmam que somente no processo existe produção de prova e que a atividade probatória das partes pressupõe a existência de um processo. Ademais, a regra relativa ao ônus da prova destina-se ao juiz, i.e., um órgão do processo, determinando-lhe certa atividade processual. $^{179}$

É justamente neste ponto, ou seja, o pertinente à classificação dos fatos, que se constitui a primeira ponte, a mais robusta ligação entre o direito processual, que estabelece a posição processual da parte onerada, e o direito material, que estabelece o conteúdo do thema probandum. ${ }^{180}$

Não se pode negar que a norma do artigo 333 e incisos do nosso CPC realiza uma função integradora no sistema ao estabelecer uma estreita ligação entre o ônus da prova e as regras de direito material sobre as quais se baseia a pretensão daquele que demanda ou

\footnotetext{
${ }^{178}$ Há quem defenda a idéia de que o ônus da prova deve receber tratamento diferenciado, harmonizando-se com as diversas necessidades do direito material. Nesse sentido MARINONI, Luiz Guilherme. Formação da convicção e inversão do ônus da prova segundo as peculiaridades do caso concreto. In NEVES, Provas..., 2009, p. 262-263. Esse tratamento diferenciado do ônus da prova, baseado nas especificidades do direito material, é uma característica do direito anglo-americano.

${ }^{179}$ Nesse sentido PATTI, Prove..., 1987, p. 47-49. O autor, todavia, nas páginas seguintes, refuta os argumentos da tese processual: a) a aplicação de quase todas as normas de direito substancial pressupõem o processo; b) a regra de juízo não pode operar sem receber do direito material a qualificação atribuída aos elementos da fattispecie; e adere à tese que assinala a natureza substancial, apresentando como argumento decisivo o fato da lei italiana, como a nossa, permitir que as partes formulem transação visando modificar a regra geral do ônus da prova: "Se infatti la norma sull’onere avesse carattere processuale non dovrebbe essere concesso alcuno spazio all autonomia privata, poiché le parti non possono modificare mediante contratti le regole del processo attinenti all attività del giudice" (transcrição ipsis litteris). E arrebata narrando que não se pode deixar de considerar a escolha do legislador (italiano) ao prescrever a norma geral sobre o ônus da prova no Código Civil. (tradução nossa).

${ }^{180}$ Nesse sentido MICHELLI, La carga..., 2004, p. 284. LUCON, Paulo Henrique dos Santos. Garantia do tratamento paritário das partes. In TUCCI, Garantias constitucionais..., 999, p. 115, reconhece haver estreita ligação entre o direito material e as regras pertinentes à "inversão" do ônus da prova constantes no CDC.
} 
daquele que excepciona no bojo do processo. ${ }^{181}$ Essa conexão se evidencia, claramente, a partir do momento que os fatos que constituem o fundamento da demanda apresentada em juízo e, ainda, a efetiva relevância desses, somente podem ser identificados com suporte nas regras de direito material. ${ }^{182}$

\subsubsection{Crítica ao critério}

O ônus da prova como é distribuído atualmente conduz a uma inércia do requerido por questões meramente técnicas. O requerido só produz prova se o autor produzir e provar. É ele quem tem que provar primeiro. Se ele não provar, ele perderá a demanda. Dessa forma, o direito processual está interferindo na ação humana diversamente da própria natureza, da própria lógica e da própria racionalidade do ser humano, pois, todo requerido, a rigor, tem interesse em provar a verdade, principalmente quanto a sua inocência (civil), ou seja, quanto aos fatos impeditivos, modificativos e extintivos do direito alegado pelo autor. ${ }^{183}$

O critério sob enfoque é alvo de inúmeras críticas, inclusive naqueles países que o adotaram. Uma das grandes dificuldades, inclusive predominantemente de natureza prática, é a de distinguir, a partir da situação fática discriminada pelo autor, o elemento ou conjunto de elementos que integram o núcleo central dos fatos, daquele elemento ou elementos meramente acidentais aos fatos.

\footnotetext{
${ }^{181}$ MICHELLI, La carga..., 2004, p. 411, sustenta haver uma fusão entre a perspectiva substancial e formal do fenômeno na mesma consideração do processo, entendido como meio para a realização do direito objetivo, uma vez que a regra de ônus da prova no processo civil não é em absoluto independente da estrutura do processo concreto.

182 Essa característica também é assente no ordenamento italiano e alemão. Cf. PATTI, Prove..., 1987, p. 84.

${ }^{183}$ CARNELUTTI, Sistema di diritto..., 1936, v. 1, p. 424 et seq. Para o autor, o interesse à prova é bilateral e, por assim ser, o critério do interesse unilateral, ou seja, interesse de cada parte, não seria idôneo a estabelecer a distribuição do ônus da prova. Afirmado um fato, ambas as partes tem interesse em produzir provas relativas ao respectivo fato, contudo, em sentidos opostos. Enquanto o autor provaria a existência do fato, o réu provaria sua inexistência (prova e contraprova). Vincula a situação de determinada parte estar em melhor condição de provar ao critério do interesse à afirmação. Segundo o jurista o interesse à afirmação, ao contrário do interesse à prova, é unilateral, pois cada parte tem interesse em afirmar os fatos constitutivos de sua pretensão e, em efeito, quem tem interesse em afirmar tem o ônus de provar sua afirmativa, ou seja, quem ajuíza uma demanda tem o ônus de provar os fatos constitutivos e, quem apresenta uma exceção tem o ônus de provar os fatos extintivos, impeditivos ou modificativos.
} 
Todavia, é possível afirmar que a definição da natureza dos fatos não deve ser abstraída pelo juiz, quando da aplicação da regra de juízo, somente pelos fatos unilateralmente apresentados pelo autor e sim diante do conjunto de fatos apresentados de forma bilateral, ou seja, por ambas as partes.

Com o objetivo de aprofundar o assunto à epígrafe e considerando a escassez da doutrina pátria, insta utilizar doravante a metodologia do direito comparado. Tal metodologia indubitavelmente evidencia-se eficiente para o alcance pretendido, considerando que as críticas ao critério adotado pelo legislador na Itália e na Alemanha guardam similitude ímpar com os problemas vivenciados em nosso ordenamento jurídico, tanto de ordem prática quanto teórica.

Por sua vez, faz-se necessário adotar um critério de distribuição do ônus da prova como parâmetro. Diante disso, considerando sua comprovada relevância teórica e sua influência nos ordenamentos jurídicos dos países europeus e respectivas colônias através dos tempos, será dada ênfase ao critério elaborado pelo professor titular da Universidade de Munique, Leo Rosenberg, em sua teoria conhecida por Normentheorie, ${ }^{184}$ a qual estabeleceu o critério de distribuição do ônus da prova no ordenamento alemão de forma incontestável.

No mencionado ordenamento, não existe previsão expressa, de âmbito geral, sobre a distribuição do ônus da prova, ou seja, uma norma semelhante a do artigo 333 do nosso CPC e a do artigo 2697 do Código Civil Italiano. Na doutrina alemã entende-se que o ônus da prova corresponde a princípios de lógica, de equidade, de adequação ao objeto e ainda, por originar de normas de direito material, pode-se deduzir dessas não apenas o thema probandum, mas também a repartição do ônus da prova. ${ }^{185}$ Não obstante a ausência de norma expressa, a regra aplicada naquele ordenamento - normentheorie - não é substancialmente diferente da norma expressa vigente na Itália.

\footnotetext{
184 A teoria foi publicada originalmente na obra Die Beweislast auf der Grundlage des Bürgerlichen Gesetzbuchs und der Zivilprozessordnung. A terceira edição alemã foi publicada em Munique, em $1^{\circ} \mathrm{de}$ dezembro de 1951. A quinta e última edição foi publicada em 1965. A obra foi traduzida para o espanhol, por Ernesto Krotoschin, sob o título La carga de la prueba.

${ }^{185}$ Nesse sentido Wach, Die Beweislast, p. 10 e ss.; Schulz, Die Beweislast, p. 4 e ss. Apud PATTI, Prove..., 1987, p. 85, nota 1 .
} 
Em síntese, conforme a normentheorie uma norma somente pode ser aplicada quanto subsistirem todos os pressupostos fáticos dessa mesma norma. Assim, o ônus de provar esses pressupostos fáticos - da norma invocada - é de incumbência da parte que se beneficiará com a aplicação dessa norma. ${ }^{186}$ Consequentemente, essa mesma parte suportará os efeitos advindos da ausência de certeza quanto à matéria fática, ou seja, quanto aos pressupostos fáticos da norma que se pretendia fosse aplicada. ${ }^{187}$

Vale ressaltar que um dos pontos de congruência entre a normentheorie, a norma italiana e a norma brasileira consiste na circunstância de que os fatos relevantes à aplicação da norma são classificados em constitutivos, impeditivos, modificativos e extintivos. Assim, no ordenamento alemão, a parte autora deve provar os pressupostos fáticos do preceito jurídico sob o qual se funda sua demanda e a parte requerida deve provar os pressupostos fáticos da norma que objetiva rechaçar a demanda autoral, i.e., os pressupostos de uma norma impeditiva, modificativa ou extintiva. ${ }^{188}$

Atualmente, em todos os ordenamentos sob enfoque, duras críticas são envidadas em face do critério de distribuição do ônus da prova, inclusive, por óbvio, à normentheorie. A esta se imputa um excessivo formalismo, o qual lhe impede de levar em consideração os múltiplos e necessários aspectos para a realização de uma verdadeira e substancial justiça; não se consegue depreender, com a clareza e precisão devidas, qual a base normativa que permite o juiz a equiparar a hipótese de non liquet à hipótese no qual o próprio juiz está convencido da inexistência do fato; refuta-se totalmente a distinção entre fatos constitutivos, modificativos e extintivos e propõe-se uma repartição do ônus da prova sob outros critérios, ganhando relevo o princípio da verossimilhança, principalmente em matéria de responsabilidade civil.

Em continuidade, afirma-se que o modelo de repartição do ônus da prova oriundo da normentheorie, bem como dos modelos italiano e brasileiro, em muitas hipóteses, tornam excessivamente difícil a produção da prova pelo demandante. Decorre daí que a

\footnotetext{
${ }^{186}$ ROSENBERG, La carga..., 2002, p. 123. Essa é a essência do princípio de distribuição do ônus da prova criado pelo autor: cada parte deve afirmar e provar os pressupostos da norma que lhe é favorável, i.e., da norma cujo efeito jurídico redunda em seu proveito. (tradução nossa).

187 Segundo PATTI, Prove..., 1987, p. 85, o resultado negativo da parte não é justificado pelo inadimplemento de um ônus, mas pela impossibilidade do juiz de aplicar a norma invoca, porque falta - não restou provada - a subsistência de um determinado pressuposto.

${ }^{188}$ Cf. ROSENBERG, op. cit., p. 130. (nota 50).
} 
jurisprudência desses países, visando sanar esse problema, vem criando diversas regras que contradiz a base teórica da normentheorie, bem como a prima facie a base legal da Itália e do Brasil, sob as vestes da denominada "inversão" do ônus da prova. ${ }^{189}$ Em efeito, essa crítica guarda estreita ligação teórica com a presente pesquisa, i.e, com a teoria da dinamização do ônus da prova.

Em síntese, vem se tornando assente, na doutrina e jurisprudência dos países em menção, a necessidade de superação do modelo tradicional de distribuição do ônus da prova, diante dos resultados insatisfatórios que a repartição sob voga tem promovido, principalmente em relação à igualdade e à justiça. ${ }^{190}$ Ademais, cresce o número daqueles que aderem a critérios não vinculados à literalidade da lei, mas que interpretam a norma com base em todos os critérios científicos disponíveis no sistema jurídico. ${ }^{191}$ Como consequência de ambos os fatos acima afirmados, a jurisprudência de vários países vem promovendo essa evolução e aplicando a dinamização do ônus da prova, sob o nome de modificação e/ou inversão do ônus da prova.

\subsubsection{Livre apreciação da prova, regras de experiência e presunções}

Esta última seção deste título é destinada a averiguar, sob uma visão crítica e moderna, se os temas à epígrafe exercem realmente alguma influência no dogma do ônus da prova, bem como em sua distribuição, quer seja positiva, i.e., contribuindo para a evolução e o aperfeiçoamento do ônus da prova, ou negativamente, i.e., gerando uma

\footnotetext{
${ }^{189} \mathrm{Na}$ Alemanha e na Itália, os exemplos mais frequentes dizem respeito à responsabilidade do produtor e o erro grave do médico. Em ambas as hipóteses vem sendo considerada muito difícil a produção da prova pelo autor, uma vez que este, regra geral, não conhece os aspectos internos e os dados técnicos do sistema produtivo ou da ciência médica, sendo imputado o ônus da prova ao produtor ou ao médico. Nesse sentido PATTI, Prove..., 1987, p. 88. Vale lembrar que a teoria das cargas probatorias dinámicas teve origem prática, i.e., em uma sentença proferida no bojo de uma demanda de ressarcimento decorrente de erro médico.

${ }^{190}$ MICHELLI, La carga..., 2004, p. 50, nesse sentido, afirma que tal concepção de ônus da prova, ao mesmo tempo em que indica a crise do conceito tradicional, mostra a necessidade de regras práticas particulares sobre a distribuição, que tenham em conta certos dados da experiência, a respeito de determinadas relações ou estados jurídicos.

${ }^{191}$ Substancialmente nesse sentido PATTI, op. cit., p. 90. (nota 16). Na visão do citado autor, o melhor de todos os princípios mencionados pela doutrina italiana, por ser o que melhor explica a evolução da norma e que oferece um fundamento de validade ao critério concretamente utilizado é o princípio da efetividade. (tradução nossa).
} 
confusão conceitual com o ônus da prova, prejudicando ainda sua aplicação na esfera prática.

Importante estabelecer como premissa que a análise a ser doravante desenvolvida refere-se somente ao ônus objetivo da prova, ou seja, à regra de julgamento. ${ }^{192}$

Não é correto afirmar que a livre apreciação da prova modifica as regras de distribuição do ônus da prova. O princípio da livre apreciação da prova estabelece que o juiz, conforme sua livre convicção, mas de forma fundamentada, pode e deve considerar como verídica determinada afirmação. Esta afirmação diz respeito aos fatos afirmados pelas partes no bojo da demanda.

Não existe fórmula relativa à formação da convicção do juiz quanto à veracidade dos fatos apresentados nos autos. A convicção se constitui livremente. Não obstante, podese afirmar que alguns fatores contribuem para o alcance desse resultado. Assim, o juiz, nesse trabalho intelectivo, utiliza princípios gerais fundados na experiência, que derivam da observação da vida, da sociedade e da conduta dos homens e dos resultados das investigações técnicas e científicas, para valorar detidamente todas as provas produzidas por ambas as partes e constantes dos autos. ${ }^{193}$

Em efeito, a livre apreciação da prova e o ônus da prova possuem áreas de atuação diversas, estando separados por limites precisos e fixos, não obstante figurar bem próximos um do outro. O princípio da livre convicção do juiz, através da livre apreciação da prova, ajuda o juiz a chegar à verdade ou não das afirmações alegadas e discutidas no processo. Já as regras sobre o ônus da prova permitem ao juiz chegar a uma solução quando o princípio da livre apreciação da prova não deu resultados, ou seja, não foi suficiente para o juiz

\footnotetext{
${ }^{192}$ Essa premissa guarda coerência metodológica com o objeto central desta pesquisa.

${ }^{193}$ ROSENBERG, La carga..., 2002, p. 214, afirma que o juiz, graças a sua instrução e educação, está ao nível da cultura de sua época e que, por sua atividade prática, conhece a situação de seu país e de sua cidade, as idéias e os costumes de seu povo. Assim, o juiz não deve ter dúvidas em um caso em que qualquer outra pessoa sensata que saiba apreciar claramente as condições da vida estaria convencida: em tal caso deve considerar suficiente a prova da verdade, sem preocupar-se de que dentro do domínio imenso das possibilidades o contrário não é, desde logo, inimaginável. Pois nenhuma prova que tenha por objeto a comprovação de afirmações de fato pode mais que convencer um homem sensato, justo e experiente. (tradução nossa).
} 
estabelecer em seu íntimo a verdade dos fatos alegados. ${ }^{194}$ Diante disso, enfatiza-se que a livre apreciação da prova, em qualquer hipótese, não modifica as regras de distribuição do ônus da prova.

As regras de experiência estabelecem que determinados fatos, de acordo com as regras da vida, devem ser tidos como prováveis, i.e., carregam em si alto grau de probabilidade. ${ }^{195}$ Assim, a parte deve provar as circunstâncias que em conformidade com as regras da vida, permitem ao juiz concluir pela verdade dos fatos afirmados. Muitas vezes essas regras se caracterizam como presunções e com essas se confundem.

Quando o juiz, com base em uma regra de experiência, forma sua convicção a respeito da verdade de uma alegação, que consiste no fundamento da demanda, isso não significa que houve modificação da regra geral do ônus da prova. Aliás, a regra relativa ao ônus da prova nem será aplicada, pois houve, na essência, convencimento do magistrado a respeito da situação fática objeto da demanda. Em efeito, a regra de experiência tem influência direta no princípio da livre convicção do juiz, pois servirá de base a comprovação da verdade de uma afirmação.

Em síntese, tanto o princípio da livre convicção do juiz quanto os princípios fundados na experiência ${ }^{196}$ em nada modificam as regras pertinentes ao regime geral do ônus da prova, pois não fornecem nenhuma contribuição para a solução do problema da ausência de certeza quanto à situação fática apresentada no bojo do processo, no momento da aplicação da regra de julgamento. ${ }^{197}$ Não é demais enfatizar que ambas atuam em momento processual anterior à incidência prática da regra de juízo.

\footnotetext{
${ }^{194}$ O domínio do ônus da prova começa onde termina o domínio da livre apreciação da prova. Se o juiz atravessou este último sem conseguir encontrar a solução, o ônus da prova lhe dá o que a livre apreciação da prova lhe negou. (tradução nossa). ROSENBERG, La carga..., 2002, p. 82.

195 Vale ressaltar que regras ou máximas de experiência não se confundem com fatos notórios, sendo conceitos bem diversos. Como distinção fulcral para nosso objeto de pesquisa, fatos notórios não precisam ser provados, o que não ocorre com as regras de experiência. Por todos, CONTE, Le prove..., 2009, p. 43.

${ }^{196}$ Os princípios fundados na experiência e as presunções, nada tem em comum. Cf. ROSENBERG, op. cit., p. 247 (nota 50); MICHELLI, La carga..., 2004, p. 168-175.

${ }^{197}$ Essencialmente nesse sentido ROSENBERG, Ibid., p. 222; MICHELLI, Ibid., p. 171-172. Este afirma que a regra do ônus da prova produz seus típicos efeitos quando a fase probatória se encerrou de forma negativa. A valoração da prova não influi atualmente, no processo civil, sobre a distribuição das consequências da falta de certeza em que o juiz se encontra após esgotados os meios de prova.
} 
O tema relativo às presunções é reconhecidamente de alta complexidade teórica. ${ }^{198}$ Apesar de ser um tema comum nas obras doutrinárias de todos os países da família civil law, poucos foram os autores que se arriscaram em sua verticalização científica. ${ }^{199}$ Até mesmo sua posição sistemática no ordenamento é controversa, i.e., se pertencem ao direito material ou ao direito processual. ${ }^{200}$

Em âmbitos gerais, as presunções se classificam em absolutas - praesumptiones iuris et de iure - e em relativas - praesumptiones iuris tantum -. Podem ser instituídas pelo legislador ou pela jurisprudência. A jurisprudência cria presunções, somente relativas, de cunho interpretativo e de cunho integrativo, ante a existência de omissões no sistema. Algumas dessas criações jurisprudenciais pertinentes ao tema da presunção, a prima facie, modificam a regra geral do ônus da prova. Para aqueles que assim entendem, essa modificação se realiza, na essência, primeira e diretamente, na regra de direito material diante do caso concreto e, somente depois e indiretamente, na regra de distribuição do ônus da prova. ${ }^{201}$

\footnotetext{
${ }^{198}$ ROSENBERG, La carga..., 2002, p. 233, afirma, discorrendo sobre o conceito da presunção legal de fato (não de direito) que em nenhuma outra parte existe tamanha confusão entre a linguagem e os conceitos, como existe na doutrina relativa às presunções. Pode-se dizer que até agora não se obteve um conceito claro sobre a presunção. (tradução e adendo entre parêntesis nosso). Ainda, MICHELLI, La carga..., 2004, p. 175.

${ }_{199}$ Justus Wilhelm Hedemann escreveu uma ampla monografia sobre o tema em 1904, mas não conseguiu obter a precisão científica desejada. Alexander Plósz, em livro em homenagem à Adolf Wach, em 1913, estudou as presunções de uma forma mais aprofundada que Hedemann. Plósz explica as presunções como uma forma de fixação legal do estado de fatos. In ROSENBERG, Ibid., p. 235-236. Uma pesquisa científica verticalizada sobre o tema deve analisar as presunções de fato e as presunções de direito. Deve averiguar com precisão quais são as diferenças, os limites, as congruências e influências recíprocas entre presunções e: a) regras relativas ao ônus da prova; $b$ ) regras de interpretação; c) ficções; d) regras de experiência; e) regras de prova e livre apreciação da prova.

${ }^{200}$ MICHELLI, op. cit., p. 176-177 (nota 50), apesar de reconhecer que a tendência da doutrina, especialmente a italiana, é de considerar as presunções como regras pertencentes ao direito processual, diverge e afirma ser normas pertencentes ao direito material. Um dos argumentos balizadores de sua posição é que as presunções geram efeitos também para fora do processo. Ademais, não tem como principal finalidade a formação da convicção do juiz e sim a de conferir uma regulação positiva a uma relação particular ou a um estado de fato particular, dispondo os elementos da hipótese de modo diferente do normal. Ainda, AUGENTI, Giacomo Primo. L'onere della prova. Roma: Società Editrice del Foro Italiano, 1932. p. 159; CHIOVENDA, Instituições..., 1965, v. 1, p. 94; ROSENBERG, Ibid., p. 260. Pela natureza processual, por todos, CAPPELLETTI, Mauro. La testimonianza della parte nel sistema dell'oralità. Milano: Giuffrè Editore, 1962. p. 176-177, nota 10.
}

${ }^{201}$ Nesse sentido PATTI, Prove..., 1987, p. 112. 
Contudo a afirmativa de que a presunção relativa modifica a regra geral de distribuição do ônus da prova, na maioria dos casos, não corresponde à realidade, estando balizada em preceitos equivocados. ${ }^{202}$

Recorrendo ao método da exemplificação, quando se fala em presunção de culpa na esfera da responsabilidade civil no nosso ordenamento, o demandante não precisa produzir prova da culpa do demandado. Isso ocorre, em concreto, não porque houve modificação direta da regra geral do ônus da prova em virtude da presunção, mas porque a presunção transforma o fato culposo e sua autoria em fato presumido e, assim, certo, provado.

Em efeito, a prova do fato culposo, a rigor, continua a ser ônus do demandante o qual, todavia, deixa de realizá-la, por ser processualmente desnecessária, ante a certeza fática (probabilidade ou verossimilhança) formada pelo fenômeno da presunção. ${ }^{203}$ Caberá, assim, ao demandado o ônus da prova desconstitutiva do fato objeto da presunção.

Na realidade, nessas hipóteses, não há qualquer modificação das regras de distribuição do ônus da prova, pois o autor, cuja presunção favorece, está apenas dispensado da produção de prova quanto ao respectivo fato. Assim, como nessa relação processual o autor, pela incidência da presunção, já provou os fatos alegados, resta ao requerido o exercício de sua atividade probatória.

Após o demandado realizar a prova desconstitutiva do direito do autor, que no caso concreto está baseada em uma presunção, o magistrado fará a avaliação das provas produzidas para, em seguida, formar sua convicção de forma livre e motivada, que cotejará a prova do fato constitutivo do direito do autor, fulcrada na presunção, e a prova desconstitutiva. Não se pode olvidar que a presunção torna o fato constitutivo provado, assim, real, nunca ensejando a aplicação da regra de julgamento.

\footnotetext{
202 TARUFFO, Michele. Presunzioni, inversione, prova del fatto. Rivista Trimestrale di Diritto e Procedura Civile, Milano, Giuffrè, anno 46, n. 3, p. 733-756, settembre 1992. p. 752, afirma que é entendimento muito difundido e aceito, provavelmente correspondendo à realidade em um significativo número de hipóteses, que as presunções legais tem a função de simplificar e facilitar o adimplemento do ônus probatório de uma das partes, através da simplificação da fattispecie.

${ }^{203}$ VERDE, L'onere della prova..., 1974, p. 226, afirma que os fatos presumidos são e permanecem fatos constitutivos e, assim, sob o âmbito do ônus probatório, deveriam ser tratados em conformidade com a regra expressa no primeiro parágrafo do artigo 2697. Se isso não acontece é porque, de vez em quanto, o legislador se preocupa em dispensar da prova a parte que deveria ser onerada secundo o critério geral de repartição. (tradução nossa).
} 
Outra consequência daí advinda, corroborando que a presunção relativa não modifica a regra geral de distribuição do ônus da prova é que diante de qualquer presunção desse gênero o juiz não poderá aplicar a regra de julgamento, conforme acima mencionado, pois, ou o demandado provou de forma efetiva a modificação, o impedimento ou a extinção do fato objeto da presunção, ou o juiz irá se satisfazer com a certeza advinda da presunção. A sentença terá um efetivo conteúdo meritório, i.e., o fato culposo ocorreu por ato do demandado, o que não ocorre com a sentença lastreada na regra de juízo. ${ }^{204}$ Conclui-se novamente, portanto, equivocado o entendimento no sentido de que a presunção relativa modifica a regra geral de distribuição do ônus da prova. ${ }^{205}$

A assertiva supra se apresenta ainda mais clara quando se coteja esse raciocínio com a teoria da dinamização do ônus da prova. Diferentemente, quando juiz aplica a dinamização do ônus da prova, no momento da sentença, o faz baseado em preceitos absolutamente diversos aos da presunção relativa, os quais não guardam qualquer ligação com certeza, probabilidade ou verossimilhança, não havendo dispensa ou isenção ${ }^{206}$ de produção de prova.

Como se verá oportunamente, quando ocorrer a dinamização do ônus da prova, o fato constitutivo do direito do autor não será presumido. A prova desse fato também não será dispensada. Todavia, como, a priori, o demandando é quem possuirá maior facilidade na produção da prova do fato desconstitutivo lato sensu do direito do autor, ele passará a ser o onerado. Caso não consiga provar ou mantenha-se inerte, ele, requerido sofrerá as consequências da ausência de formação de certeza, e não o autor. A sentença, assim, será baseada em regra de juízo, e não em fatos tidos por certos com base em presunção relativa.

Utilizando o mesmo exemplo acima mencionado, responsabilidade civil decorrente de culpa, na dinamização do ônus da prova o demandado passa a ter o ônus de produzir prova do fato desconstitutivo do direito do autor, regra geral, diante de sua maior e efetiva

\footnotetext{
${ }^{204}$ Cf. nota 211.

205 Nesse sentido ROSENBERG, La carga..., 2002, p. 244. Afirma que é falso traduzir como presunções as regras comuns sobre o ônus da prova, em particular, estabelecer presunções em favor da ausência dos chamados fatos impeditivos.

${ }^{206}$ VERDE, L`onere della prova..., 1974, p. 228, afirma que em relação aos fatos presumidos é disposta uma mera dispensa da prova a favor daquele que usufrui da presunção. Ainda, CHIOVENDA, Instituições..., 1965 , v. 2, p. 374.
} 
facilidade em produzir a prova em detrimento da dificuldade ou efetiva impossibilidade da parte autora produzir a prova constitutiva de seu direito. Isso não quer dizer que a prova do fato constitutivo do autor esteja realizada ou mesmo que será dada como provada pelo juízo. Se o demandado não produzir a prova que lhe incumbe, o juiz irá aplicar a regra de julgamento e, consequentemente, julgar procedente o pedido autoral pela ausência de certeza quanto aos fatos desconstitutivos do direito do autor. Esse é o raciocínio técnicojurídico do ônus objetivo da prova.

Vê-se, por fim, diante disso, que a afirmativa recorrente na nossa doutrina de que a presunção modifica a regra geral de distribuição do ônus da prova é absolutamente equivocada, sob o prisma do ônus objetivo da prova. ${ }^{207}$

\subsubsection{Conteúdo da sentença}

Como anteriormente foi citado, é comum na doutrina a afirmativa de que a sentença baseada na regra de juízo, i.e., no ônus da prova objetivo, tem conteúdo meritório e que os fatos considerados pelo juiz como não provados devem ser tidos como fatos inexistentes.

Todavia, conforme também advertido, essa afirmativa não goza da simplicidade que aparenta, em âmbito teórico. Na essência desta complexa questão está a indagação sobre a existência de conteúdo normativo da sentença baseada na regra de julgamento. ${ }^{208}$

Se a regra de julgamento, derivada da disciplina do ônus da prova, tem por objetivo precípuo impedir que o juiz profira um decisum de non liquet e, se essa regra somente deve

\footnotetext{
${ }^{207}$ Parcialmente nesse sentido BARBOSA MOREIRA, As presunções e a prova, 1988, p. 60-61 e 67. Não obstante afirmar que, sem sombra de dúvida, as normas que consagram presunções relativas são normas de atribuição do onus probandi, sustenta não parecer inteiramente exato que a presunção legal relativa se revolve em inversão do ônus da prova. Para o autor as presunções legais não constituem propriamente exceções à regra comum sobre distribuição do ônus da prova, pois as normas que as consagram são, isso sim, normas especiais, que prevalecem sobre a geral, sem necessariamente contradizê-la in concreto. O resultado da aplicação da regra especial, contida no dispositivo que estabelece a presunção, pode coincidir, em determinado caso, com o resultado que se obteria aplicando à espécie a regra geral de distribuição daquele ônus. (grifos do autor).

${ }^{208}$ VERDE, L`onere della prova..., 1974, p. 125, afirma que esta regra (de juízo) é derivada de exigências sistemáticas e conceituais, sendo totalmente desprovida de conteúdo normativo. (tradução e adendo entre parêntesis nosso).
} 
ser aplicada na hipótese da atividade probatória da parte ter sido ausente ou não ter sido hábil a formar o convencimento do julgador, deixando-o com dúvidas, incertezas, quanto aos fatos alegados, como poderá o juiz afirmar na sentença que os fatos são inexistentes se, justamente, a base de aplicação dessa regra é a incerteza?

Em outras palavras, o juiz, baseado na regra de juízo, afirma ao jurisdicionado, e ainda à sociedade - princípio da publicidade -, apesar de não possuir qualquer convicção e certeza quanto à existência ou inexistência dos fatos alegados pelo autor, que considera inexistentes os respectivos fatos e, assim, julga improcedente o pedido autoral, cuja sentença é apta ao trânsito em julgado formal e material. ${ }^{209}$

Necessário, antes da continuidade da abordagem, fixar a seguinte premissa: não se objetiva contestar a validade e a eficácia da regra de julgamento - ônus objetivo da prova para o subsistema processual civil, pois, indubitavelmente, é uma regra fundamental para a completude do ordenamento jurídico, ao impedir o sibi non liquet. Entretanto, objetiva-se sustentar que, ao aplicar a regra sob enfoque, o magistrado não deve considerar tais fatos como efetivamente inexistentes, assim expondo na sentença, pois não possui essa convicção, uma vez que essa certeza não consta dos autos e, em efeito, dele não pode ser abstraída pelo juiz.

O juiz deve simplesmente, na sentença, aplicar a regra de julgamento baseada no ônus da prova objetivo e, assim, julgar improcedente o pedido autoral, com fundamento no respectivo dispositivo legal.

Na hipótese do fato alegado pelo autor realmente ter existido, mas não ter sido provado, o juiz estaria transformando uma incerteza processual em certeza, processual e fática, atentando principalmente contra a realidade fática, o que gera um déficit de legitimidade e credibilidade ao poder jurisdicional.

Na essência, a regra de julgamento traz em seu bojo uma determinação, e não mera autorização, para o julgador rejeitar a demanda e, assim, rejeitar os pedidos apresentados

\footnotetext{
${ }^{209}$ Em linguagem coloquial, é como se o Juiz de Direito dissesse: eu, juiz, não tenho certeza, mas digo-lhes que os fatos são inexistentes.
} 
pela parte onerada cujos fatos não foram provados. ${ }^{210} \mathrm{Em}$ efeito, ao juiz não é facultado, nessas hipóteses de ausência e/ou insuficiência de provas, pronunciar o non liquet, acolher a demanda ou rejeitá-la.

Diante disso, pode-se afirmar que a sentença baseada em regra de juízo - ônus objetivo da prova - é desprovida de conteúdo, pois os fatos não provados não devem ser considerados fatos existentes ou mesmo inexistentes. Daí deriva outra questão a ser resolvida em face da ausência de conteúdo normativo: identificar qual o instrumento jurídico hábil a sustentar, no bojo do sistema, a incidência do fenômeno da coisa julgada material.

De antemão, imperioso afirmar que é absolutamente equivocado considerar que a regra do ônus da prova objetivo estabelece uma presunção quanto à inexistência dos fatos não provados, pois se estará, assim, estabelecendo uma regra probatória de formação da convicção. ${ }^{211}$ Esta hipótese elimina a incerteza oriunda dos autos e a própria incidência da regra de julgamento.

Sob o âmbito essencialmente teórico, considera-se que a regra de juízo concretiza uma equiparação entre a ausência ou a insuficiência de prova dos fatos alegados à inexistência desses. Essa equiparação de cunho teórico se concretiza sob o plano normativo, recorrendo-se ao esquema da ficção jurídica, i.e., situação hipotética da qual a lei faz derivar uma determinada consequência. ${ }^{212}$

Em síntese, somente se vislumbra coerência teórico-jurídica, no bojo do direito processual civil, relativamente à aplicação da regra de juízo - ônus objetivo da prova -, o conteúdo da sentença proferida com base nessa regra e à incidência da coisa julgada material, se o fato não provado nos autos, por obra de ficção jurídica, for equiparado a fato inexistente.

\footnotetext{
${ }^{210}$ Nesse sentido VERDE, L`onere della prova..., 1974, p. 27. Afirma o autor que a função da regra de juízo não deveria ser aquela de impedir ao juiz de pronunciar uma sentença de non liquet, mais deveria concretizarse naquela função que poderíamos definir como consequência de uma escolha de civilidade, já que se proíbe ao juiz dar por existentes fatos os quais não foi ofertada prova plena e convincente. (tradução nossa).

${ }^{211}$ Nesse sentido Ibid., p. 117-118. Ainda, AUGENTI, L`onere della prova, 1932, p. 159.

212 Nesse sentido Ibid., p. 112-113; 120-121. Afirma Verde que o legislador faz uma "equiparação entre a fattispecie processual da incerteza e a conclusão processual da inexistência do fato.". (tradução nossa). Ainda, AUGENTI, Ibid., p. 160.
} 
Essa equiparação, ad abundantiam, é feita automaticamente pela própria regra de julgamento, prescindindo de qualquer declaração do juiz nesse sentido, quando do proferimento da sentença. 


\section{TEORIA ${ }^{213}$ DA DINAMIZAÇÃO DO ÔNUS DA PROVA}

Os dois primeiros títulos desta pesquisa, além dos propósitos específicos de cada assunto, desenvolvidos de uma forma lógico-natural e sequencial, tiveram a função metodológica de preparação e ligação intelectiva ao terceiro título, onde será abordado o tema central deste trabalho.

Propositadamente, buscou-se percorrer um caminho teórico-jurídico obrigatório e necessário para identificar a essência, a inteireza e a validade científico-jurídica da teoria da dinamização do ônus da prova. ${ }^{214}$

A teoria da dinamização do ônus da prova, em conformidade com o direito processual civil brasileiro e o sistema jurídico em que este está inserido, será devidamente conceituada, desenvolvida e concluída no decorrer deste título, através dos próximos capítulos e pertinentes seções. Em outras palavras, será integralmente constituída com suporte nos pilares teóricos do nosso direito constitucional e processual civil e, ao final, apresentada à crítica dos cientistas do direito.

\footnotetext{
213 A palavra teoria, nas ciências sociais, tem sido empregada de forma bastante diversa, incluindo quase tudo, desde as menores hipóteses de trabalho, às amplas, mas vagas e desordenadas especulações, até os sistemas axiomáticos de pensamento, daí o cuidado que se deve ter no uso da palavra, posto que frequentemente, obscurece a compreensão ao invés de suscitá-la. Cf. MERTON, Robert King. Sociologia: teoria e estrutura. São Paulo: Mestre Jou, 1970. p. 51. Pode-se definir teoria científica como sendo uma síntese aceita de um vasto campo de conhecimento, consistindo-se de hipóteses necessariamente falseáveis, mas não por isto erradas, dúbias ou tão pouco duvidosas, que foram e são permanentemente e devidamente confrontadas com os fatos científicos, fatos estes que integram um conjunto de evidências que, juntamente com as hipóteses, alicerçam o conceito de teoria científica. Em efeito, uma teoria científica é o conjunto indissociável de dois subconjuntos: o subconjunto de fatos naturais, evidências necessariamente verificáveis, e um subconjunto de hipóteses adequadas à descrição destes fatos, de idéias necessariamente falseáveis, testáveis e testadas frente às evidências. No pensamento científico o fato sempre é superior à idéia, sendo que o fato sempre pode destruir a idéia. Por isso, uma teoria científica é sempre formada a partir de hipóteses. As teorias devem ser submetidas criticamente à prova dos fatos e selecionadas de acordo com os resultados obtidos, através da dedução lógica e da comparação dos resultados, havendo quatro diferentes linhas para submeter uma teoria à prova: a) comparação lógica das conclusões umas com as outras, para se testar a coerência interna do sistema; b) investigação da forma lógica da teoria, com objetivo de determinar se ela apresenta caráter de uma teoria empírica, cientifica ou tautológica; c) comparação com outras teorias, para ver se há avanço de ordem cientifica, e; d) comparação da teoria por meio de aplicações empíricas das conclusões que dela se possam deduzir. Cf. POPPER, Karl Raimund. A lógica da pesquisa científica. São Paulo: Cultrix, 1996. p. 33 et seq.

${ }^{214}$ Uma das conclusões essenciais dos títulos anteriores é que a teoria da dinamização do ônus da prova não altera a predominância do aspecto objetivo do dogma do ônus da prova e que, além da concepção tradicional de prova como ônus, agrega as concepções de prova como direito e dever.
} 
Para tal, não serão dispensadas, pois necessárias, algumas idas e vindas conceituais, determinadas repetições de estruturas e fundamentos já apresentados, tudo visando o perfeito esclarecimento e consequente entendimento do que será exposto, justificando, dessa maneira, ainda mais a existência dos dois títulos precedentes.

O desenvolvimento, mantendo-se a metodologia utilizada e visando a melhor compreensão do objeto da pesquisa consistirá, efetivamente, em um raciocínio técnicojurídico contínuo, apesar da divisão em capítulos e seções. Serão averiguados, inicialmente, os aspectos históricos da teoria pós-moderna para em seguida, iniciando a construção da teoria da dinamização do ônus da prova, apresentar de forma detalhada os elementos conceituais e estruturais e, por fim, os fundamentos de aplicabilidade da teoria da dinamização, no espaço jurídico do direito processual civil brasileiro. 


\subsection{ASPECTOS HISTÓRICOS}

Nesta seção, de cunho predominantemente introdutório, objetiva-se apresentar, além da gênese da teoria de las cargas probatorias dinámicas, i.e., da teoria pós-moderna, concebida originariamente em solo argentino, os seus fundamentos, características e as críticas feitas pela respectiva comunidade jurídica.

Vale ressaltar que essa abordagem, por outro lado, visa ainda possibilitar, em âmbito teórico, a transcendência da teoria supra citada e aplicada no ordenamento jurídico do país vizinho, a outro ordenamento jurídico bem diverso, sem, contudo, possuir a mínima e descabida pretensão de importação.

Pode-se afirmar ainda, com toda convicção, apesar da aproximação de cunho ideológico, quanto à ciência do direito processual civil, que toda a construção teóricojurídica da teoria da dinamização do ônus da prova, objeto desta pesquisa, é absolutamente diversa, consistindo esta em uma teorização original a ser aplicada no ordenamento jurídico brasileiro.

\subsubsection{Origem}

A teoria de las cargas probatorias dinámicas pode ser considerada uma teoria pósmoderna sobre o ônus da prova, tanto pelo fator temporal em que foi concebida, quanto pela sua essência e conteúdo jurídicos. ${ }^{215}$

\footnotetext{
215 As teorias relativas ao ônus da prova podem ser seccionadas sob dois critérios. O primeiro seria o temporal, no qual seriam classificadas em teorias antigas, evidenciadas no último quartel do século XVIII e no século XIX; teorias modernas, criadas em sua maioria na Itália e na Alemanha, no século XX e, teoria pós-moderna, instituída no final do século XX, aproximadamente em seu último quartel. O segundo critério seria de acordo com sua natureza jurídica, podendo ser classificadas em teorias de inspiração civilista e teorias de inspiração processualista. Este último critério foi anunciado por Alfredo Buzaid. As teorias antigas tiveram inspiração unicamente civilista e foram instituídas sob uma visão de processo vinculada e, porque não dizer, subserviente ao direito material, antes da fase autonomista da ciência processual. Já as duas seguintes tiveram inspiração precipuamente processualista. Quanto às teorias sob enfoque, duas conclusões são claras: a) a maioria delas, ao invés de se excluírem, se complementa e, b) a escolha do critério ou dos critérios para a distribuição do onus probandi ficou a cargo do legislador, cabendo à doutrina e à
} 
Esta teoria foi difundida inicialmente com a denominação de teoria de las cargas probatorias dinámicas $^{216} \mathrm{e}$, quanto aos fatores tempo e espaço, tem sua origem controvertida.

Há quem diga que sua gênese advém do século XIX. ${ }^{217}$ Quem assim defende, baseia-se em dois argumentos. Alicerça-se, essencialmente, nos escritos do filósofo e jurista inglês Jeremias Bentham sobre o tema da distribuição do ônus da prova, em sua obra “Tratado de las Pruebas Judiciales". ${ }^{218}$ Segundo Bentham, em um sistema de justiça franco e simples, a obrigação da prova deve ser imposta, caso a caso, à parte que puder satisfazê-la com menos inconvenientes, vale dizer, menores despesas, menor perda de tempo e menor incômodo. ${ }^{219}$ Para o referido autor o princípio segundo o qual quem propõe a demanda deve provar a verdade é um princípio tão falso quanto absoluto. ${ }^{220} \mathrm{Na}$ essência, ao tentar estabelecer um critério para a distribuição do ônus da prova, Bentham trouxe para o direito sua filosofia utilitarista.

O segundo argumento, que reforça o primeiro, no sentido de ter sido Bentham seu precursor, consiste na afirmação de que essa teoria, além de já ser conhecida na Alemanha, teria sido objeto de críticas por Leo Rosenberg em sua obra "La Carga de la Prueba".

jurisprudência sua adequada interpretação e devidas inovações. Importante ressaltar, ainda, que durante todo o período de vigência dessas teorias, poucos foram os pesquisadores que se detiveram em averiguar quem deveria realizar a distribuição do onus probandi, se o legislador, o juiz ou as próprias partes. Cf. BUZAID, Do ônus da prova, 1972, p. 69.

${ }^{216}$ A teoria em menção também foi denominada pela doutrina e jurisprudência argentinas como carga dinámica de la prueba, carga de prueba compartida, cargas probatorias dinámicas, doctrina de la prueba compartida. Cf. WHITE, Inés Lépori. Cargas probatorias dinámicas. In PEYRANO, Jorge Walter. Cargas probatorias dinámicas. 1. reimp. Santa Fé: Rubinzal-Culzoni Editores, 2008. p. 69. O próprio Peyrano, nesta mesma obra (p. 169), apresentou outra co-denominação: la solidaridad de la prueba.

${ }^{217}$ Nesse sentido GARCÍA GRANDE, Maximiliano. Cargas probatorias dinámicas: ni nuevas, ni argentinas, ni aplicables. [S.1.: s.n.], 2005. Disponível em: <http://www.e-derecho.org.ar/congresoprocesal/ Cargas\%20Probatorias\%20Din\%E1micas\%20_Grande_.pdf >. Acesso em: 29 novembro 2010.

${ }^{218}$ Escrita originalmente em inglês, essa obra foi traduzida primeiramente para o francês, sob o título "Traite des Preuves Judiciaires" e, posteriormente, para a língua espanhola. Vale ressaltar ainda que fora escrita antes da fase autonomista do direito processual. Em seu contexto, duas frases foram marcantes: "El que pone la demanda es el que debe probar su verdad; principio tan falso como absoluto", e, "la prueba debe presentarla la parte que pueda hacerlo con menos inconvenientes".

${ }^{219}$ In Tratado de las pruebas judiciales. Escrita em francês por Estevan Dumont. Traducido al castellano por C.M.V. Paris: Bossange Frères, 1825. v. 3. p. 151. Ainda, SOARES DE FARIA, Principaes theorias..., 1936, p. 38.

${ }^{220}$ In BENTHAM, Ibid., p. 286. 
Entretanto, ao cotejar os textos citados acima, de Bentham e Rosenberg, com a teoria supra mencionada apresentada inicialmente por Peyrano, vislumbra-se não ser possível imputar à primeira obra sua gênese. Pode-se admitir que Bentham tenha apresentado uma de suas idéias centrais, contudo em outro contexto histórico, social e, principalmente jurídico, o do direito anglo-saxão. Quanto à Rosenberg, ao criar sua teoria sobre o ônus da prova, na metade do século XX, não se pode afirmar com precisão que tratou do assunto sob enfoque, valendo ressaltar que não há qualquer citação de Bentham em toda sua obra.

Diante disso, pode-se imputar ao jurista argentino Jorge Walter Peyrano, inspirado nas idéias de ônus processual de James Goldschmidt, ${ }^{221}$ a introdução e o desenvolvimento da teoria sob menção, o que se deu de forma descontínua, por intermédio de vários trabalhos isolados sobre o tema, acompanhando atentamente os movimentos do direito doutrina e jurisprudência - de seu país.

O conceito de ônus processual, inspirador da teoria em exame, consistiu no eixo central do sistema processual proposto por Goldschmidt. Este entendia que os vínculos jurídicos que nascem no processo entre as partes, não são propriamente relações jurídicas, ou seja, faculdades ou deveres no sentido de poderes sobre imperativos ou ordens, e aqui necessário abrir parêntesis para esclarecer que Goldschmidt considerava essas relações jurídicas como um fenômeno estático do direito.

Continuando, ele vislumbrava esses vínculos como situações jurídicas, i.e., fenômeno dinâmico do direito, ou seja, como situações de expectativa, de esperanças quanto à conduta judicial a ser realizada e, em último caso, quanto à decisão judicial futura. Essas expectativas, possibilidades e ônus são direitos em sentido processual, o mesmo direito que o cidadão tem, por exemplo, à tutela jurídica, sendo que o ônus, foco de atenção de Peyrano como imperativo do próprio interesse das partes, ocupa sempre dentro do processo o lugar das obrigações. ${ }^{222}$

\footnotetext{
${ }^{221}$ In Derecho procesal civil. Trad. Leonardo Prieto Castro. Barcelona: Labor, 1936.

${ }^{222}$ No original: "Los vínculos jurídicos que nacen de aquí (alude al 'proceso') entre las partes no son propiamente relaciones jurídicas (consideración estática del Derecho); esto es, no son facultades ni deberes en el sentido de poderes sobre imperativos o mandatos, sino situaciones jurídicas (consideración dinámica del Derecho), es decir, situaciones de expectativa, esperanzas de la conducta judicial que ha de producirse y, en último término, del fallo judicial futuro; en una palabra: expectativas, posibilidades y cargas. Sólo aquéllas
} 
Peyrano, magistrado no Juizado da quinta nominação da cidade de Rosário, proferiu sentença, em caso de erro médico, aplicando a teoria de las cargas probatorias dinámicas em 1978. Por volta de 1981, o mencionado jurista publicou o primeiro artigo sobre a teoria, em co-autoria com Julio O. Chiappini, intitulado "Lineamientos de las cargas probatorias dinámicas", 223 apresentando-a, assim, à comunidade jurídico. ${ }^{224}$

Em vários momentos o próprio Peyrano e outros autores reconheceram que a teoria nasceu como um paliativo para aliviar a impossível tarefa de um paciente que havia sido vítima de erro médico no momento da cirurgia e que, no bojo de uma demanda de responsabilidade civil médica, não tinha condições de cumprir com o ônus da prova naquele caso específico, ou seja, o de provar a culpa do médico. ${ }^{225}$

son derechos en sentido procesal - el mismo derecho a la tutela jurídica (acción procesal no es, desde este punto de vista, más que una expectativa jurídicamente fundada) - y las últimas, las cargas, 'imperativos del propio interés', ocupan en el proceso el lugar de las obligaciones.”. GOLDSCHMIDT, Derecho procesal..., 1936, p. 8. Carnelutti, em suas obras "La Prueba Civil" e "Lecciones de Derecho Procesal Civil", estrutura seu conceito de ônus processual de forma diversa de James Goldschmidt. Para Carnelutti ônus processual tem fundamento conceitual no fenômeno da sanção. Afirma que "La distinción entre carga y obligación se funda en la diversa sanción conminada a quien no realiza un acto: existe sólo obligación cuando la inércia da lugar a la sanción jurídica (ejecución o pena); en cambio, si la abstención del acto hace perder sólo los efectos útiles del acto mismo, tenemos la figura de la carga.”. Na obra Sistema, v. 1, p. 55, Carnelutti desloca a base conceitual de ônus processual do fenômeno da sanção para o do interesse: "obligación y carga tienen de común el elemento formal, consistente en el vínculo de la voluntad, pero divergen en cuanto al elemento sustancial, porque cuando media obligación, el vínculo se impone para la tutela de un interés ajeno y cuando ha carga, para la tutela de un interés propio". CARNELUTTI, Francesco. La prueba civil. 2. ed. Buenos Aires: Depalma, 2000. p. 217 e 218.

${ }^{223}$ Cf. PEYRANO, Jorge Walter. Nuevos lineamientos de las cargas probatorias dinámicas. In PEYRANO, Cargas probatorias..., 2008, p. 19, nota 1; Cf. ainda PEYRANO, Jorge Walter. De la carga probatoria dinámica embozada a su consagración legislativa. In Ibid., p. 169, nota 1.

${ }^{224}$ Pode-se afirmar, com elevado grau de certeza que, na Argentina, a teoria de las cargas probatorias dinámicas teve sua origem marcada por uma decisão judicial, sendo introduzida naquele universo jurídico por intermédio da sentença mencionada no texto supra. Daí em diante a teoria, no referido ordenamento jurídico, além de ter sido amplamente aceita pela doutrina e jurisprudência, teve sua área de aplicabilidade largamente ampliada a diversas outras hipóteses concretas, v.g., demandas pertinentes a concursos públicos, contratos bancários, indenização, locação, responsabilidade contratual e extracontratual etc., sem que tivesse sido inserida no direito positivado daquele país. Depreende-se, assim, dos fatos acima narrados, a indubitável importância do precedente judicial como fonte do direito. O decisum mencionado teve uma dimensão de eficácia com altíssimo grau de influência sobre futuras decisões, não só análogas como em situações diversas, sem contar no fato de ter sido a gênese de uma teoria jurídica de elevada importância e aceitabilidade. Cf. TUCCI, José Rogério Cruz. Precedente judicial como fonte do direito. São Paulo: Editora Revista dos Tribunais, 2004. p. 307, em relação à dimensão de eficácia da jurisprudência. Nos presente dias encontra assento pacífico na Corte Suprema Nacional do citado país.

${ }^{225}$ Cf. RAMBALDO, Juan Alberto. Cargas probatorias dinámicas: un giro epistemológico. In PEYRANO, Cargas probatorias dinámicas, 2008, p. 32; PEYRANO, Jorge Walter. La doctrina de las cargas probatorias dinámicas y la máquina de impedir en materia jurídica. In Ibid., p. 80. Peyrano afirma que a teoria nació como un paliativo para aligerar la ímproba tarea de producir pruebas diabólicas que, en ciertos supuestos, se hacía racaer, sin miramientos, sobre las espaldas de alguna de las partes (actor o demandado) por mal entender las tradicionales y sacrosantas reglas apriorísticas de distribución de la carga de la prueba. Importante ressaltar que essa passagem, evidentemente, não retrata a dimensão e importância da teoria. Cf. 


\subsubsection{Fundamentos}

Analisando a mencionada teoria de las cargas probatorias dinámicas pode-se abstrair que um dos seus objetivos consiste em complementar e aperfeiçoar as regras tradicionais vigentes sobre o onus probandi.

Em efeito, pode-se ainda identificar como um de seus fundamentos a necessidade de se flexibilizar a aplicação das regras fixas vigentes sobre o tema, quando aquela parte que deve provar, segundo essas regras, não tem condições de fazê-lo, por motivos absolutamente alheios a sua vontade. Assim, não interessa a posição da parte no processo, se autor ou demandado, devendo produzir a prova, especialmente, aquela parte que se encontra em melhores condições para tal. Da mesma forma, em âmbitos gerais, não interessa a natureza do fato alegado, ou seja, se constitutivo, impeditivo, modificativo ou extintivo do direito do autor. ${ }^{226}$

Em outras palavras, a teoria sob comento deve ser aplicada naquelas situações em que os critérios estabelecidos pela lei quanto à distribuição do ônus da prova, não se mostram adequados e eficazes para atingir o seu fim. Nessas situações o onus probandi deve recair sobre aquela parte que guarda melhores condições técnicas ou fáticas para produzi-las.

A teoria de las cargas probatorias dinámicas, originariamente, apresenta três fundamentos: $:^{227}$ a) a justiça aplicada ao caso concreto, ou seja, a equidade; b) a atitude das partes no processo e, c) a responsabilidade do juiz no processo. Não obstante, não há dúvidas que o principal fundamento da teoria sob análise é a justiça-equidade.

ALTHUSSER, Luis. La filosofia como arma de la revolución. Buenos Aires: Pasado y Presente, 1968. É necessário nunca perder de vista que, entendida em sentido estrito, a teoria nunca se reduz aos exemplos reais invocados para ilustrá-la, porque supera todo objeto real dado e pertence a todos os objetos reais possíveis que dependem de seus conceitos.

${ }^{226}$ Vale ressaltar, todavia, que o critério da natureza dos fatos, que influenciou inúmeras legislações, tem uma indiscutível lógica: ao autor incumbe a prova dos fatos constitutivos de seu alegado direito. Ao demandado, a prova dos fatos extintivos, modificativos e/ou impeditivos do direito do adversário.

${ }^{227}$ Cf. WHITE, Cargas probatorias dinámicas, 2008, p. 66-68. 
A atitude das partes no processo aparece como fundamento da presente teoria, se contrapondo, ainda que de forma modesta, à natureza precipuamente dispositiva do processo civil. Todas as vezes que um indivíduo passa à condição de parte no processo, não é somente para fazer uso de seus direitos, mas também, consequentemente, assume determinados deveres. Assim, tanto as partes quanto seus respectivos advogados, uma vez integrantes da relação jurídica processual, tem o dever processual de conduzir-se com lealdade, probidade e boa-fé. Esse dever, por sua vez, desdobra-se no dever de colaboração na produção da prova, para que o juiz possa alcançar a verdade material.

Quanto ao terceiro fundamento, ou seja, a responsabilidade dos magistrados no processo, também em contraposição ao que prega o princípio dispositivo, informador da maioria das legislações pertinentes ao processo civil no mundo ocidental, não tem os magistrados o papel de meros guardiões da ordem e da compostura. É da essência da magistratura impedir que os mais fortes, aqueles que tem uma posição econômica, social ou jurídica mais vantajosa, tanto no aspecto substancial quanto no aspecto processual, sejam beneficiados em detrimento dos mais fracos, por intermédio de instrumentos legais que proporcionem o efetivo equilíbrio dessas forças. E para estes, a única garantia real e verdadeira é a existência de um juiz interessado em sua função e preocupado com a evidência dos fatos no processo, possibilitando o proferimento de uma justa sentença.

Em síntese, ao conjugar harmonicamente as regras tradicionais do onus probandi com a justiça no caso concreto, ${ }^{228}$ com os deveres do juiz e com os deveres de conduta processual das partes, se obtém as bases, os fundamentos, da teoria de las cargas probatorias dinámicas, ${ }^{229}$ em sua concepção originária.

Possível, ainda, citar outros fundamentos vislumbrados pela doutrina e jurisprudência argentina, v.g., concepção dinâmica do processo, dever de colaboração entre os profissionais - advogados -, necessidade de equilibrar as diferenças existentes entre as partes no processo.

\footnotetext{
${ }^{228}$ A Suprema Corte Argentina tem clarificado que as regra atinentes ao ônus da prova devem ser apreciadas em função da índole e características do assunto submetido à decisão do órgão jurisdicional e da necessidade de se dar primazia, ao interpretar as normas processuais, à verdade jurídica objetiva. Cf. MORELLO, Augusto Mario. Dificultades de la prueba en procesos complejos. Santa Fé: Rubinzal-Culzoni, 2004. p. 5152 e nota 2.

${ }^{229}$ Cf. WHITE, Cargas probatorias dinámicas, 2008, p. 68.
} 


\subsubsection{Características}

Umas das características da teoria de las cargas probatorias dinámicas é ser considerada uma doutrina de exceção, justamente por ter sido vislumbrada com o fim de dar soluções adequadas a demandas específicas, diante de desigualdades existentes entre as partes, que acabavam por desaguar em decisões definitivas injustas.

Consequentemente, não é objetivo da teoria sob enfoque galgar à condição de outra regra geral ou a de única regra de distribuição do ônus da prova, o que desvirtuaria sua idéia original. Sua pretensão consiste em ser um instrumento jurídico que possa ser aplicado em situações excepcionais nas quais aquelas regras rígidas não correspondam ao escopo do processo e ao princípio de justiça. ${ }^{230}$

Quanto a critérios definidores de distribuição de onus probandi a presente teoria também não tem vocação para enfoques apriorísticos, v.g., natureza do fato a ser provado, posição processual das partes etc., pois, como nova forma de conceber o fenômeno da distribuição do onus probandi, está centrada nas circunstâncias do caso concreto.

Em síntese, é possível concluir que a presente teoria, ao permitir a distribuição dinâmica do ônus da prova, rompe a tradição de estabelecimento prévio e abstrato do ônus da prova, desconsidera a posição da parte na relação processual, não importando se o indivíduo figura como autor ou requerido, bem como a diferenciação dos fatos em constitutivos, impeditivos, modificativos e extintivos, enfatizando e priorizando os fatos e circunstâncias concretas da demanda e aquela parte que efetivamente se encontra em melhores condições de produzir determinada prova.

Em âmbito da jurisprudência argentina, a teoria de las cargas probatorias dinámicas já foi aplicada em demandas de diversas naturezas, v.g., pertinentes a acidentes

\footnotetext{
${ }^{230}$ Substancialmente nesse sentido PEYRANO, Cargas probatorias..., 2008, p. 24. Para o autor "De lo que se trata es, pues, no de propiciar otra regla rígida de distribución de la carga de la prueba que concurre en un pie de igualdad con los parámetros legalmente regulados, sino de formular una pauta "excepcional" que sólo puede funcionar allí donde aquéllas manifiestamente operan mal porque fueron elaboradas para supuestos "normales y corrientes" que no son los correspondientes al caso.".
} 
de trânsito, concursos públicos, contrato de depósito, contratos bancários, criminal correcional, indenização, falsificação de cheques, locação, imprensa, responsabilidade contratual e extracontratual, responsabilidade médica, seguridade social, simulação, títulos de crédito. $^{231}$

Quanto ao momento de aplicação, considerando as regras que disciplinam o procedimento do processo civil ordinário argentino, a teoria de las cargas probatorias dinámicas é aplicada no momento do proferimento da sentença, mantendo seu caráter de regra de julgamento, não encontrando assento na Corte Suprema Nacional do citado país, a tese de ofensa ao contraditório diante de suposta surpresa. ${ }^{232}$

\subsubsection{Críticas}

A teoria sob análise é alvo de críticas tanto de ordem teórica quanto práticojurídica. Um primeiro argumento contrário e, sem dúvida o mais cômodo para aqueles que não concordam com a aplicação da teoria de las cargas probatorias dinámicas, consiste na ausência de texto legal. Esse argumento suscita a questão relativa às fontes do direito e à legalidade estrita.

É assente, desde o século passado, que a lei, apesar de todos os dogmas que a envolvem, não é a única fonte de direito. A criação pretoriana é um exímio exemplo de fonte de direito. Inúmeras figuras jurídicas são criadas por obra da reiteração de entendimentos expostos em decisões judiciais que, em virtude de sua legitimidade advinda da necessidade de acompanhar as evoluções sociais e dar uma resposta eficaz a essa moderna sociedade, se tornam vinculantes aos aplicadores do direito, antes mesmo de se tornar lei.

Um segundo argumento e, incontestavelmente o mais relevante sob a ótica processual, consiste na possível ofensa ao princípio do devido processo legal, a partir do

\footnotetext{
${ }^{231}$ In PEYRANO, Cargas probatorias..., 2008, p. 70.

232 Cf. WHITE, Cargas probatorias..., 2008, p. 73. Ainda BARBERIO, Sérgio José. Cargas probatorias dinámicas: qué debe probar el que no puede probar? In PEYRANO, Ibid., p. 105-107.
} 
momento que a aplicação da teoria possa ou efetivamente cause surpresa para uma ou ambas as partes.

Outros argumentos que se apresentam consistem na falta de utilidade da aplicação da teoria sob enfoque, na incidência do brocardo nemo tenetur edere contra se e a potencial dificuldade do juiz identificar no caso concreto quem está em melhores condições de realizar a prova. 


\subsection{DINAMIZAÇÃO DO ÔNUS DA PROVA NO PROCESSO CIVIL BRASILEIRO}

A impossibilidade de se formular um critério geral, abstrato e prévio de distribuição do ônus da prova que satisfaça todas as hipóteses de aplicação do direito diante da existência de incerteza, de dúvida quanto à situação fática, quando do provimento final do magistrado, momento no qual então deverá decidir sobre um fato incerto, é algo assente em doutrina específica sobre o tema. ${ }^{233}$

A premissa acima, ao mesmo tempo em que ainda desafia a comunidade jurídica pátria e estrangeira a buscar um instrumento jurídico que possa ser contundente na solução desse problema de cunho teórico e prático, gera a convicção de que a dinamização do ônus da prova é esse instrumento almejado. ${ }^{234}$

Como já mencionado no capítulo anterior, foi por intermédio do jurista argentino Jorge Walter Peyrano que a teoria pós-moderna sobre o tema foi introduzida na comunidade jurídica, por volta de 1981, na obra "Lineamientos de las cargas probatorias dinámicas". 235

Todavia, mostra-se necessária a realização de uma reestruturação teórica da citada teoria de las cargas probatorias dinámicas, não perdendo de vista o caráter essencial de toda teoria de cunho científico, que é a universalidade, mas voltando as lentes microscópicas desta pesquisa para um foco de atenção específico: o nosso ordenamento jurídico e o sistema processual civil brasileiro.

\footnotetext{
${ }^{233}$ Por todos, MICHELLI, La carga..., 2004, p. 277.

${ }^{234}$ Corroborando a importância da presente teoria, RAMBALDO, Cargas probatorias dinámicas: un giro..., 2008, p. 33, sustenta que a recepção da doutrina das cargas probatorias dinámicas para a teoria da ciência do direito processual produziu um verdadeiro giro epistemológico fundamental no modo de observar o fenômeno probatório, passando a ser visto com a percepção da finalidade do processo e do valor justiça e não mais sob o ângulo de mero cumprimento de formas processuais abstratas. (tradução nossa).

${ }^{235}$ Cf. PEYRANO, De la carga probatoria dinámica embozada..., 2008, p. 169. À primeira, outras obras se seguiram sobre a teoria: Doctrina de las cargas probatorias dinámicas. Procedimiento civil y comercial. Rosário: Juris, 1991. v. 1. p. 77 et seq; Aspectos procesales de la responsabilidad profesional. Las responsabilidades profesionales. Coord. Augusto M. Morello. La Plata: LEP, 1992. p. 261 et seq.
} 
Diante disso, evidencia-se que o aperfeiçoamento teórico e a introdução de novos elementos, conceituais e estruturais à teoria, ao final, lhe permitirão uma nova configuração, consistindo esta em uma efetiva e original contribuição à ciência jurídica, mormente ao direito processual civil brasileiro. ${ }^{236}$

Atingido tal objetivo, acredita-se que esta pesquisa possa se tornar fonte de justificação e fundamentação para a aplicação da teoria da dinamização do ônus da prova de lege lata pela comunidade jurídica pátria, além de autorizar a sua imediata introdução em nosso sistema jurídico positivado.

Afinal, como indica sua própria denominação, dinamização retrata a capacidade de ser móvel, ${ }^{237}$ sendo sua maior característica a adaptabilidade aos casos concretos para garantir o direito material de quem o realmente tem, estando assim em perfeita sintonia com o princípio da efetividade da tutela jurisdicional. ${ }^{238}$

Nesse passo, é indiscutível que a presente teoria está estruturada sob uma visão publicista do processo, com enfoque destacado à atividade processual das partes dimensionada em uma concepção cooperativista do processo. ${ }^{239}$

Importante ressaltar novamente que a tentativa de romper em definitivo ou de mitigar a tradicional visão de imobilidade, rigidez, da distribuição do ônus da prova, tem

\footnotetext{
${ }^{236}$ Afinal, as idéias rígidas e excludentes já não desfrutam de prestígio e, como consequência, surge a necessidade de harmonizar os sistemas aparentemente antagônicos, mais que buscar o triunfo de uns sobre outros. A nova mentalidade é reticente a aceitar as explicações e alternativas totalizantes. [...] Atualmente se dissemina a necessidade de sermos mais amistosos com os outros e com a realidade do mundo, deixando de lado a onipotência e a imposição. (tradução nossa). In PEYRANO, Jorge Walter. El derecho procesal postmoderno. Revista de Processo, São Paulo, v. 21, n. 81, p. 141-145, jan-março 1996. p. 142.

${ }^{237}$ BARBERIO, Cargas probatorias dinámicas: qué debe probar..., 2008, p. 106, retrata com ênfase esse caráter móvel da teoria da dinamização do ônus da prova afirmando que o ônus probatório poderá trasladarse de uma parte à outra, vice-versa, e retornar sobre a mesma, segundo resultar da atividade desenvolvida pelos litigantes em todo o processo. (tradução nossa).

${ }^{238}$ Nesse diapasão a presente teoria da dinamização do ônus da prova está em plena consonância com os tempos pós-modernos. Na lição de PEYRANO, El derecho procesal postmoderno, 1996, p. 142, também característico dos tempos pós-modernos é o endeusamento do pragmatismo como valor supremo e o critério da eficácia como última ratio do sistema social, político e epistemológico. Típica assim a preocupação atual com o desempenho, o interessar-se sobremaneira pela eficácia, de tal maneira que essa (eficácia) tornou-se o imaginário social central da sociedade pós-moderna. (tradução nossa).

${ }^{239}$ Substancialmente nesse sentido KNIJNIK, As (perigosíssimas) doutrinas do "ônus dinâmico da prova”..., 2006, p. 945.
} 
sido objeto de importantes obras de renomados juristas desde o século XVIII. ${ }^{240}$ Essa dificuldade se evidencia maior nos países cujo sistema jurídico remonta à tradição romanística (direito codificado) - sistema da civil law -, sendo que os da experiência jurídica da common law (direito casuístico), de origem anglo-saxônica, adotam, a flexibilidade na distribuição do ônus probatório, cada um a sua maneira. ${ }^{241}$

Não obstante, também nos países da civil law esse fenômeno da dinamização da distribuição do ônus da prova vem sendo objeto de pesquisas, ainda que sob outras roupagens e enfoques. ${ }^{242}$

Enfim, parece inegável que o direito processual despertou para a necessidade de se quebrar o paradigma, a priori invencível, incontestável, quase divino, de que ao autor incumbe e sempre incumbirá, prioritariamente, o ônus da prova. Isto não soa mais como uma verdade absoluta, nem se sustenta como verdade científica, tanto sob o prisma teórico, quanto o mais sob o prático. ${ }^{243}$

$\mathrm{Na}$ verdade, tanto o legislador quanto o juiz devem estar atentos às eventuais e contingentes mudanças que ocorrem no seio da sociedade, a qual apresenta como traços característicos marcantes a dinamicidade e a flexibilização, pois estas irão gerar uma

\footnotetext{
${ }^{240}$ Afirma RheinZ Mendelssohn-Bartholdy, que a distribuição do ônus da prova conforme regras legais fixas é o pior inimigo de um poder judicial forte e sempre se opõe a realização do dever da parte de conduzir o processo honestamente. (tradução nossa). Apud ROSENBERG, La carga..., 2002, p. 85, nota 30.

${ }^{241}$ Uma das principais diferenças entre a disciplina da distribuição do ônus da prova nos países da civil law, em comparação aos da common law, situa-se no sistema de verificação judicial do fato. Na Inglaterra e nos Estados Unidos da América vige o adversary sistem, onde o magistrado praticamente não possui qualquer poder instrutório, sendo inerte em matéria probatória, sob pena de configurar sua imparcialidade. Nesse sentido DAMASKA, Il diritto delle prove..., 2003, p. 120-121.

${ }^{242} \mathrm{Na}$ Itália, v.g., TARUFFO, Presunzioni, inversione..., 1992, p. 747-748, discorrendo sobre os mecanismos legais ou jurisprudenciais de inversão ou modificação do ônus da prova ressalta que uma questão que se pode suscitar é saber se tais mecanismos são funcionais e racionais, bem como qual o seu objetivo. E complementa enfatizando que se, de fato, se parte da premissa que a regulamentação dos ônus probatórios se justifica em função do acerto dos interesses substanciais que se objetiva conseguir, então se deve considerar que são justificadas as relativas manipulações. Ainda, por todos, DENTI, Vittorio. L`inversione dell onere della prova: rilievi introduttivi. Rivista Trimestrale di Diritto e Procedura Civile, Milano, Giuffrè, ano 46, n. 3, p. 709-714, settembre 1992. p. 709-714; VERDE, Giovanni. L inversione degli oneri probatori nel processo. Ibid., p. 715-732.

${ }^{243}$ No direito alemão, a tal conclusão já se chegou há mais de uma década em âmbito do direito constitucional e administrativo. Necessário advertir que no sistema alemão, assim como no italiano, tal matéria é vista sob o prisma do direito substancial. Afirma KOKOTT, The burden of proof..., 1998, p. 12-13, que "The rationale behind the German (Rosenberg's) "norm theory" and the principle onus probandi actori incumbit presupposes a conflict of interests characteristic of private litigation, but absent in constitutional or human rights law. [...] The "norm theory" or "onus probandi actori incumbit" is suited for adversarial civil lawsuits, and not for administrative and constitutional law issues, where different kinds of material antagonism between the rights of the parties exist". (adendo entre parêntesis nosso - grifos do autor).
} 
demanda similar ao sistema jurídico, que não pode deixar de conceder uma resposta na mesma velocidade que as transformações sociais, sob pena de perder considerável parcela de sua legitimidade. ${ }^{244}$

Diante dessa forte pressão, não é suficiente qualquer espécie de resposta por parte do Estado, pois é necessário que essa seja contemporânea e guarde coerência, senão observância, aos objetivos precípuos da justiça. ${ }^{245}$

\footnotetext{
${ }^{244}$ RODRIGUES, Processo civil ambiental, 2008, p. 132, atento às transformações necessárias ao direito, afirma que a "mudança de concepção (privatista para publicista) faz com que a prova, ou os meios de prova, deixem de ser utilizados como mecanismos de obstaculização do direito, na medida em que, verificando-se a fraqueza do meu adversário, acaba-se adotando a postura inerte de sonegação (hipossuficiência) de informações, para se aguardar, em favor do recalcitrante, a regra fria do art. 333 do CPC para os casos de non liquet.".

${ }^{245}$ Nessa mesma visão e, em complemento, GRECO, Leonardo. Paradigmas da justiça contemporânea e acesso à justiça. Revista de direito da Unigranrio. [S.1.: s.n.], [19--]. Disponível em: <http://publicacoes.unigranrio.edu.br/index.php/rdugr>. Acesso em: 07 outubro 2010. p. 12. Enfatiza que para tirar do processo o maior proveito possível nessa função, impõe-se a observação da realidade social e econômica do mundo atual, o que certamente permitirá ir em busca de mecanismos processuais mais eficazes do que aqueles que normalmente são apresentados pela doutrina tradicional. A justiça a todo o momento se depara com essa realidade e as respostas que ela é capaz de dar geralmente ficam muito aquém das expectativas dos jurisdicionados, patenteadas no noticiário cotidiano dos órgãos de imprensa.
} 


\subsubsection{ELEMENTOS CONCEITUAIS}

\subsubsection{Primeiras linhas}

Importante ressalvar, inicialmente, que os elementos que compõem a conceituação da teoria da dinamização do ônus da prova vem sendo expostos desde o início deste título, de forma sistêmica e gradual. ${ }^{246}$

Necessário também estabelecer a premissa de que não se pretende instituir com a presente teoria a fixação de conceitos rígidos, engessados, em relação a um fenômeno cuja principal característica é o dinamismo.

Não resta dúvida que cada elemento que compõe este fenômeno é importante em sua completude conceitual. Diante disso, conveniente abrir parêntese para esclarecer que alguns elementos relevantes para a exata identificação do fenômeno que ora se pesquisa, v.g., os requisitos, o momento, limites e consequências da aplicabilidade da teoria sob enfoque, serão objeto de detalhada análise mais adiante.

Doravante, nestas primeiras linhas conceituais, será utilizado o método de lógica jurídica pertinente à conjugação de fórmulas para apresentar e esclarecer, ainda que parcialmente, a conceituação do fenômeno e demonstrar a aplicabilidade da teoria da dinamização do ônus da prova no nosso sistema jurídico processual.

\footnotetext{
${ }^{246}$ Importante para uma visão geral da teoria da dinamização do ônus da prova, o entendimento de MORELLO, Dificultades de la prueba..., 2004, p. 52. Afirma que "el concepto de "carga dinámica de la prueba" o prueba (gestión) compartida es empleado habitualmente cuando los extremos, hechos conducentes, los que son determinantes y llevan el significado del caso, son de muy difícil comprobactión [...], y consiste en hacer recaer dicha carga sin subordinarla a un patrón teórico rígido y cerrado [el art. 377, CPN] en quien, em cambio, se halla en mejor situación de aportar los elementos tendientes (o por un alto grado de especialización, habitualidad, profesionalidad o superioridad técnica) a obtener la solución de la controversia, más allá de lo dispuesto por la norma de ese precepto legal. Y ello es así (quiere decir comprensible y lógico) porque tiende a privilegiar la verdad objetiva sobre la formal, a efectos de brindar la efectiva concreción judicial justa, aun abandonando los preceptos rígidos, para perseguir una resolucíon judicial adecuada, según las circunstancias fácticas de las delicadas y especiales (complejas y difíciles) cuestiones integrantes de la litis.".
} 
Firmadas tais premissas, afirma-se, em continuidade, que dinamizar significa dar caráter dinâmico a alguma coisa. Refere-se a movimento, atividade. É, em efeito, exatamente o oposto a tudo aquilo que é estático, inativo, inerte. ${ }^{247}$

Dinamizar o ônus da prova é atribuir o caráter dinâmico ao dogma do onus probandi, permitindo ao magistrado, quando da utilização da regra de julgamento, transformar a regra estática que disciplina o tema em algo dinâmico, ativo, observando determinados requisitos que serão objeto de análise adiante.

Necessário ressalvar que a teoria da dinamização do ônus da prova não objetiva conceder aos magistrados amplos poderes a ponto de permitir que eles, arbitrariamente, estabeleçam caso a caso, as regras sobre a distribuição do ônus da prova. Não é essa a essência da teoria e, definitivamente, não se trata disso.

Não se pode negar e deixar de mencionar, todavia, que a teoria confere ao magistrado, diversamente da distribuição rígida, pré-estabelecida e em abstrato, considerável grau de poder interpretativo, pois para aplicá-la, será necessário, diante da ausência de certeza oriunda da inércia da respectiva parte na produção da prova ou de sua insuficiência, utilizar a regra de julgamento sob enfoque, após analisar as circunstâncias específicas do caso concreto. Deverá, dessa forma, averiguar, v.g., qual das partes tem maior facilidade fática na produção da prova, se uma das partes está em situação de desigualdade perante a outra, enfim, identificar quais situações em que os critérios estabelecidos pela lei quanto à distribuição do ônus da prova não se mostram adequados e eficazes para atingir o seu fim.

Ponto marcante da teoria em análise é aquele que imputa ao magistrado, essencialmente na fase procedimental do saneamento, o dever de informar ${ }^{248}$ às partes de que, naquele caso concreto, poderá aplicar a dinamização do ônus da prova, caso seja necessário utilizar a regra de julgamento do ônus da prova, advertindo-as quanto às consequências de eventual inércia e do seu dever de colaboração na busca da verdade.

\footnotetext{
${ }^{247}$ Cf. MICHAELIS, Dicionário..., 2002, p. 265; FERREIRA, Aurélio Buarque de Hollanda. Pequeno dicionário brasileiro da língua portuguesa. 11. ed. Rio de Janeiro: Editora Civilização Brasileira S.A., [19--]. ${ }^{248}$ Cf. Título I, seção 1.2.3 e Título III, seção 3.2.2.2 deste trabalho, quanto ao dever do magistrado de informar às partes, relativamente à possibilidade de aplicação da dinamização do ônus da prova.
} 
Este ponto é de extrema relevância na presente teoria, pois sem a efetivação desse dever de informação prévia às partes a consistência da mesma se esvazia. Restaria imperfeita a teoria da dinamização do ônus da prova se não houvesse um meio teórico, aliado à prática procedimental, que permitisse ao magistrado alertar às partes que tal teoria poderia ser aplicada no momento oportuno, como regra de julgamento e, conjuntamente, alertar às partes quanto à conduta relativa à produção de provas, permitindo que ambas exercitem de forma plena o direito constitucional à produção de provas e, ao mesmo tempo, evitando que o direito igualmente constitucional das partes à ampla defesa seja transgredido. Este dever de informação se harmoniza com o princípio fundamental do processo civil expresso na cláusula constitucional do due process of law.

A regra geral da distribuição do ônus da prova consiste em uma distribuição rígida, estática, engessada e pré-estabelecida pelo legislador no artigo 333 e incisos do CPC. Utilizando o método de lógica jurídica, a esta regra geral apresentamos a fórmula: ${ }^{249}$ ÔNUS DA PROVA RÍGIDO = A [fca $] \times \mathrm{R}=\mathrm{SfR}$. O resultado da aplicação desta fórmula será um julgamento de improcedência, pois como o autor tinha o ônus de provar o fato constitutivo de seu direito e se manteve inerte na produção da prova ou produziu prova insuficiente, o magistrado, diante da ausência de demonstração dos fatos alegados pelo autor, aplicará e fundamentará sua sentença na regra de julgamento - ônus da prova objetivo.

Ao aplicar a teoria da dinamização do ônus da prova, flexibilizando a regra rígida, verificamos a seguinte fórmula: ${ }^{250}$ DINAMIZAÇÃO DO ÔNUS DA PROVA = A x R [fda - fma fea] = SfA. O resultado da aplicação dessa fórmula será um julgamento de procedência,

\footnotetext{
${ }^{249}$ Fórmula lógico-jurídica sobre o tema e respectiva legenda: ÔNUS DA PROVA RÍGIDO = A [fca] x R = SfR. Ou seja, cabe ao autor provar o fato constitutivo de seu direito. Caso não cumpra seu ônus, diante da aplicação da regra de julgamento baseada na regra rígida, será proferida uma sentença de improcedência, favorecendo o requerido. Leia-se:

$\mathrm{A}=$ autor

$\mathrm{R}=$ requerido

fca $=$ fato constitutivo do direito do autor

$\mathrm{fda}=$ fato desconstitutivo do direito do autor

fma $=$ fato modificativo do direito do autor

fea $=$ fato extintivo do direito do autor

SfA = sentença favorável ao autor - procedência

$\mathrm{SfR}=$ sentença favorável ao réu - improcedência

${ }^{250}$ DINAMIZAÇÃO DO ÔNUS DA PROVA = A x $\mathrm{R}[\mathrm{fda}-\mathrm{fma}-\mathrm{fea}]=$ SfA. Ou seja, cabe agora ao requerido provar o fato impeditivo, modificativo ou extintivo do direito do autor, antes deste provar o fato constitutivo de seu direito. Caso não cumpra seu ônus, diante da aplicação da regra de julgamento baseada na dinamização, será proferida uma sentença de procedência, favorecendo o autor. Cf. Legenda na nota anterior.
} 
pois como agora caberia ao requerido provar o fato desconstitutivo/impeditivo, modificativo, extintivo do direito do autor e se manteve inerte na produção da prova ou produziu prova insuficiente, o magistrado, diante da ausência de demonstração dos fatos que deveriam ter sido satisfatoriamente provados pelo requerido, aplicará e fundamentará sua sentença na regra de julgamento - ônus da prova objetivo.

A conhecida inversão do ônus da prova será detalhadamente analisada em seção posterior. Porém, diante da proximidade temática, expomos desde já sua respectiva fórmula: ${ }^{251}$ INVERSÃO DO ÔNUS DA PROVA = A $\times$ R [fca $]=$ SfA.

Evidentemente que as fórmulas aqui apresentadas tem a finalidade precípua de demonstração, sem a pretensão de esgotamento do tema, pois podem ocorrer algumas variáveis que modificariam o resultado da aplicação da teoria sob enfoque, como por exemplo, quando o juiz aplica parcialmente a dinamização do ônus da prova, ou seja, distribui dinamicamente o onus probandi para algum ou alguns fatos principais da demanda. Desta forma, teríamos a seguinte fórmula: ${ }^{252}$ DEMANDA Y $=[$ FATO A: ÔNUS DA PROVA RÍGIDO $=\mathrm{A}[\mathrm{fca}] \mathrm{x}$ R] $+[$ FATO B: DINAMIZAÇÃO DO ÔNUS DA PROVA $=\mathrm{A} \times \mathrm{R}[\mathrm{fda}-$ fma - fea] $]=X$.

\subsubsection{Conceito de ônus processual versus dinamização}

Antes de prosseguir faz-se necessário firmar a premissa de que a dinamização do ônus da prova em nada altera a autonomia conceitual de ônus processual.

\footnotetext{
${ }^{251}$ INVERSÃO DO ÔNUS DA PROVA = A x $\mathrm{R}[\mathrm{fca}]=$ SfA. Ou seja, na inversão, cabe ao requerido provar o fato constitutivo do direito do autor. Caso não cumpra esse ônus, diante da aplicação da regra de julgamento baseada em regra pré-fixada específica, será proferida uma sentença de improcedência, favorecendo o próprio requerido. Cf. Legenda na nota 249. Cf., ainda, desenvolvimento do tema da inversão do ônus da prova frente à dinamização na seção 3.2.1.4 deste capítulo.

${ }^{252} \mathrm{Na}$ fórmula da dinamização parcial do ônus da prova, incidirá a regra rígida para determinado fato, sendo que para o outro fato, aplicar-se-á a dinamização. Caso ambas as partes mantenham-se inertes, o juiz irá valorar qual o fato prejudicial em relação ao outro e proferirá sentença aplicando a regra de julgamento relativamente ao fato prejudicial da demanda. Cf. Legenda na nota 249.
} 
Somente no século $\mathrm{XX}^{253}$ sedimentou-se a denominada teoria dos ônus processuais, eliminando qualquer possibilidade de ligação teórico-conceitual entre ônus e obrigação. Atualmente, precisa a distinção e precisos os conceitos de ambos os termos.

Pode-se conceituar ônus processual, acompanhando grande parte da doutrina pátria, como sendo o poder ou faculdade que o indivíduo possui de praticar certos atos e adotar certa conduta prevista em lei, em seu próprio interesse e benefício, sem que haja qualquer tipo de coação nesse sentido e sem que exista outro sujeito que tenha o direito de exigir sua observância. Entretanto, sua inobservância gera ao onerado consequências desfavoráveis. $^{254}$

Todavia, não configura ônus quando o resultado pretendido, i.e., a obtenção do respectivo interesse não depender necessariamente do cumprimento do respectivo ato, da respectiva conduta. Desta forma, o ato processual somente pode ser qualificado como ônus quando o comportamento do sujeito for necessário para o alcance de seu efeito.

Em uma análise bem detida, apesar de não ser esse o objeto desta seção, verifica-se que o termo ônus, em relação ao ônus da prova é impróprio, no sentido da justeza técnicojurídica do termo, pois o convencimento do magistrado quanto à verdade da matéria fática não guarda relação direta com o cumprimento do respectivo ato, i.e., com a produção da prova pela parte onerada, pois o respectivo interesse, o resultado pretendido, pode ocorrer de forma independente da atividade probatória da parte cuja demanda ou defesa foi acolhida. $^{255}$

${ }^{253}$ DINAMARCO, Candido Rangel. A instrumentalidade do processo. 13. ed. rev. e atual. São Paulo: Malheiros, 2008. p. 237, afirma que a teoria dos ônus processuais, sua conceituação, distinção de figuras afins, inserção no sistema do processo, constitui uma das mais lúcidas e preciosas contribuições que se aportaram à sua ciência no século XX, servindo para esclarecer muitos pontos de dúvida e ditar o correto direcionamento e justa medida das consequências dos possíveis comportamentos comissivos ou omissivos das partes.

${ }^{254}$ Substancialmente nesse sentido ECHANDÍA, Teoría general..., 1988, v. 1, p. 420-421. Afirma que "un poder o una faculdad (en sentido amplio), de ejecutar, libremente, ciertos actos e adoptar cierta conducta prevista en la norma para benefício y en interés propios, sin sujeción ni coacción y sin que exista outro sujeto que tenga el derecho a exigir su observancia, pero cuya inobservancia acarrea consecuencias desfavorables.". Ainda PATTI, Prove..., 1987, p. 33. Afirma, com base na doutrina tradicional, que o ônus é caracterizado pela necessária correlação entre o exercício de uma faculdade e a obtenção de um interesse.

${ }^{255}$ Nesse sentido IRTI, Due saggi..., 1973, p. 78 e ss.; PATTI, Ibid., p. 33 e 35. Este narra que não lhe parece correto afirmar - em relação ao ônus da prova - que na hipótese do ônus, uma certa conduta deve ser observada pelo interessado quando este quer atingir um fim não alcançável de outra forma, e que o exercício da faculdade conexa ao ônus é necessária para conseguir o resultado favorável. 
Em efeito, se ônus (processual) pode ser conceituado como sendo uma necessidade prática que o titular de um poder-faculdade possui, podendo exercitá-lo quando desejar obter um efeito favorável, o qual dependa imprescindivelmente do cumprimento do ato previsto, o ônus da prova pode ser conceituado como sendo a conveniência prática de um certo comportamento para obter um resultado favorável. A diferença entre ambos é que em relação a este último não se pode falar de um único meio para alcançar o resultado pretendido, pois este pode ser atingido mesmo diante do inadimplemento da parte onerada quanto a sua faculdade de produção de prova. ${ }^{256}$

Apesar disso, não é pertinente, nem necessário, deixar de utilizar a terminologia tradicional e secular do ônus da prova. ${ }^{257}$

Assim, ônus é um poder ou uma faculdade, uma situação jurídica ativa, o que implica dizer que o indivíduo é livre para agir, para observar o contido na norma ou não e que, caso opte por não observá-la, isso de nenhuma forma configurará ato ilícito civil e, muito menos, ensejará a possibilidade de lhe ser aplicada qualquer sanção. Além do mais, a norma criadora de um ônus tutela interesse do próprio sujeito onerado.

Quanto à obrigação, consiste esta em um vínculo jurídico quanto ao seu cumprimento, sempre em favor de outrem. É uma situação jurídica passiva. Assim, o sujeito não tem escolha. Tem de cumprir o conteúdo da norma obrigacional, sob pena de seu descumprimento implicar ilícito civil e ensejar, como consequência, a aplicação de determinada sanção. A norma obrigacional, assim, tutela interesse do titular do direito subjetivo correspondente, que pode exigir o seu cumprimento.

Pode-se concluir, assim, que a teoria da dinamização do ônus da prova, da mesma forma como restou evidenciado em relação ao ônus objetivo da prova, teoricamente analisado no título precedente, também não gera modificações no conceito de ônus (processual). Mesmo diante da aplicação da teoria da dinamização, no caso concreto, a parte onerada continua a ter um ônus, sendo-lhe facultado praticar o respectivo ato de natureza probatória quando desejar e no intuito de obter um efeito favorável.

\footnotetext{
${ }^{256}$ Substancialmente nesse sentido PATTI, Prove..., 1987, p. 36.

${ }^{257}$ Nesse sentido Ibid., p. 35.
} 


\subsubsection{Distribuição do ônus da prova: conceito, finalidade e forma ${ }^{258}$}

A distribuição do ônus da prova é o ponto central de aplicabilidade, de atuação prática da teoria da dinamização do ônus da prova. É essencialmente na distribuição desse ônus que a teoria sob enfoque incide e transcende do campo teórico ao prático.

Distribuir significa repartir. O que se reparte é o ônus da produção da prova e respectivas consequências da inatividade ou deficiência dessa produção.

Essa distribuição, que consiste em uma técnica ${ }^{259}$ jurídico-processual, é destinada a dois fins, sendo um principal e outro acessório, traço que não retira a importância deste no que toca ao fenômeno como um todo. Desde já vale ressaltar que, diante dessa característica de acessoriedade, óbvia a existência de interdependência, ligação intrínseca entre ambos os fins.

O fim principal é dotar o sistema processual de uma norma de julgamento que possa ser utilizada em situações limites nas quais os sujeitos do processo, autor, réu e também o juiz, considerando seu poder instrutório, não obtiveram êxito em produzir provas hábeis a formar o convencimento do magistrado quanto à situação fática apresentada pelas partes. Evidente que o fracasso na atividade instrutória do juiz não gera consequências processuais na medida em que gera às partes. Como desdobramento natural do fim principal dessa técnica encontra-se a vedação ao sibi non liquet.

\footnotetext{
${ }^{258} \mathrm{O}$ tema da distribuição do ônus da prova será abordado nesta seção sob uma visão crítica. A visão clássica foi objeto de análise no título precedente, mormente na seção 2.1.6 et seq.

${ }^{259}$ Oportuno aqui estabelecer o sentido de técnica jurídica. A técnica jurídica é a atividade destinada a dar forma aos objetos da ciência e da política jurídica, traduzindo-os em normas precisas e orgânicas. Consiste em um conjunto de meios e procedimentos destinados a transformar a norma jurídica em regras práticas e eficazes no meio social a que se destina. Indicam, em outras palavras, os meios de que se devem valer os homens para alcançar os fins que se propõem. A técnica só é o meio, indispensável sem dúvida, porém sempre o meio, para realizar os fins que perseguem a ciência. O estudo científico e a política só fornecem a matéria prima da norma: a técnica a modela, a adapta e a transforma para alcançar a realização prática desses propósitos. O direito é elaborado e aplicado mediante regras técnicas. Cf. GONÇALVES, Aroldo Plínio. Técnica processual e teoria do processo. Rio de Janeiro: AIDE Editora, 2001. p. 31-36; BECÚ, Ricardo Zorraquín; MOUCHET, Carlos. Introducción al derecho. Buenos Aires: Librería Editorial Depalma, 1953. p. 161-166.
} 
A finalidade acessória desta técnica é de orientação, um fim de conteúdo programático, através do qual se dá uma fórmula a cada parte contendo a natureza dos fatos que se deve provar para obter êxito em suas pretensões e as respectivas consequências caso não o faça ou o faça de forma insatisfatória.

A distribuição em menção, por opção político-legislativa, pode ocorrer de forma rígida (inflexível) ou dinâmica (flexível). Cada forma de distribuição poderá conter um ou vários critérios para sua operacionalização. Assim, por exemplo, uma legislação que adota a distribuição rígida dos ônus probatórios, poderá estabelecer como critérios dessa distribuição a natureza do fato e/ou a posição processual das partes. Uma legislação que adota a distribuição dinâmica, o critério escolhido poderá ser, por exemplo, o da igualdade entre as partes ou o da maior facilidade em produzir a prova. ${ }^{260}$

Na distribuição rígida, pré-estabelecida pelo legislador, a distribuição ocorre primeiramente em abstrato. Diante do caso concreto o juiz limitar-se-á, meramente, a ratificar a distribuição feita pela lei, sem qualquer margem de flexibilização. No limite, o juiz não distribui nada, apenas aplica a respectiva regra de julgamento na hipótese correspondente.

$\mathrm{Na}$ distribuição dinâmica, o legislador ou o julgador irá estabelecer regras permissivas da dinamicidade e suas limitações. A distribuição, aqui, ocorrerá diante do caso concreto, caso a caso, de acordo com as circunstâncias específicas apresentadas pelas partes. O juiz passa a ser protagonista, decidindo, fundamentadamente, a quem incumbirá os ônus probatórios. Sua atuação torna-se, desta forma, imprescindível para o descobrimento da verdade possível, para a realização da justiça, para a efetividade do processo, para o alcance do resultado pretendido, tanto sob a ótica do direito processual quanto do direito material.

Vale registrar que nos sistemas processuais modernos não se aceita mais uma passividade mórbida e maléfica do juiz. Até mesmo a passividade imposta ao juiz de common law, sendo esta uma das características principais do adversary system, vem sendo

\footnotetext{
${ }^{260}$ Uma distribuição errônea do ônus da prova pode induzir o juiz a conclusões errôneas e, assim, a uma sentença errônea, ainda quando não está em questão, propriamente, a aplicação de uma norma sobre o ônus da prova. ROSENBERG, La carga..., 2002, p. 88.
} 
contestada e mitigada. A liberdade do juiz de civil law na instrução probatória relativamente à possibilidade de produção de prova ex officio, tem um valor inestimável, pois é uma consequência direta da responsabilidade que o juiz tem de decidir corretamente, ou seja, de estabelecer a verdade no caso concreto, o que se aplica, ipsis litteris, à distribuição do ônus da prova e sua dinamização. ${ }^{261}$

A distribuição dos ônus probatórios em nosso sistema processual civil, em âmbito de classificação, apesar de não parecer à primeira vista, não é clara. Pode-se afirmar que a situação real em que se encontra o tema em nosso ordenamento jurídico é obscura, ambígua e, portanto, indesejável. ${ }^{262}$

Por obra do Código de Processo Civil de 1973, retalhado dos "pés à cabeça", bem como ainda por força da tradição do direito lusitano (Ordenações do Reino de Portugal), que seguiu a tradição do direito comum, que por sua vez derivou da tradição do direito romano, tem-se uma distribuição prévia, em abstrato e rígida, disciplinada pelo artigo 333, incisos I e II do citado diploma legal.

O conteúdo deste artigo é claro aos estabelecer os ônus probatórios de acordo com a natureza do fato (constitutivo, modificativo, impeditivo e extintivo) e a posição processual das partes, isso de forma rígida, em abstrato.

Entretanto, o sistema do direito processual civil gravita em torno de um sistema maior, o sistema jurídico, o qual contém regras de hierarquia superior, além de preceitos e princípios informadores que se sobrepõem a qualquer outro. Aliás, essa a função desses preceitos e princípios: ordenar e harmonizar o sistema como um todo.

O nosso ordenamento jurídico, cuja fonte positiva maior é a Constituição Republicana em vigência, diante dos direitos e garantias fundamentais à ordem jurídica

\footnotetext{
${ }^{261}$ DAMASKA, Il diritto delle prove..., 2003, p. 133.

262 Ante a dificuldade de estabelecer critérios processualmente autônomos para distribuir o ônus da prova, uma vez que o critério do artigo 333 e incisos do nosso CPC apresenta forte vinculação com o direito substancial, conforme frisado anteriormente, pode-se concluir que a interpretação da regra de juízo está vinculada à estrutura do processo civil, às posições de autor e demandado e às posições das partes em relação ao efeito jurídico pretendido. Cf., quanto à influência da estrutura do processo civil na distribuição do ônus da prova, MICHELLI, La carga..., 2004, p. 406, 409, 411, 418 et seq.
} 
justa, à igualdade e à prova, ali direta ou indiretamente inseridos, diante das metodologias contemporâneas da instrumentalidade do processo e do processo cooperativo (visão solidarista do processo) e suas consequências e derivações de ordem processual e, diante do princípio geral e universal de direito expresso no dogma da justiça, exige do juiz uma postura de harmonização sistêmica, o que torna imperativa a aplicação da distribuição dinâmica do ônus probatório.

Importante consignar que não se está sustentando uma revogação ou, até mesmo, uma inconstitucionalidade do disposto no artigo 333 e incisos do CPC. O que se está evidenciando e afirmando é que essa disposição legal necessita de harmonização sistêmica, uma vez que, por si só, não mais atende aos anseios da sociedade, à efetividade e finalidade do direito processual e, via de consequência, à própria atividade jurisdicional.

Em efeito, até que haja uma alteração da lei processual civil, o Estado-juiz terá as duas formas de distribuição dos ônus probatórios convivendo no sistema jurídico, ou seja, a distribuição rígida, legitimada pela lei e, pari-passu, a distribuição dinâmica, legitimada pelo ordenamento jurídico pátrio. ${ }^{263}$ Essa convivência é caracterizada por intrínsecas relações de complementaridade e sucessividade quanto a sua aplicabilidade.

Tais relações serão objeto de explicitação a posteriori, porém, insta esclarecer desde já que as duas formas de distribuição podem ser aplicadas conjuntamente, no mesmo caso concreto, de acordo com os fatos alegados pelas partes, ou seja, para determinado fato aplica-se a regra rígida, para outro, dinamiza-se. ${ }^{264}$

\subsection{Distribuição rígida: visão crítica}

\footnotetext{
263 A legitimidade da distribuição dinâmica do ônus da prova também decorre dos direitos e garantias fundamentais constitucionais à ordem jurídica justa, à igualdade e à prova, direta ou indiretamente inseridos na CR/88, pelas metodologias contemporâneas da instrumentalidade do processo e do processo cooperativo (visão solidarista do processo) e suas consequências e derivações de ordem processual e pelo princípio geral e universal de direito expresso no dogma da justiça.

${ }^{264} \mathrm{Cf}$. nota 250.
} 
A distribuição rígida dos ônus probatórios estabelecida pelo artigo 333 e incisos do CPC não pode ferir o direito fundamental ao processo justo, o direito fundamental à igualdade e o direito fundamental à prova. Assim, o juiz, no caso concreto, deverá averiguar a adequação desses direitos fundamentais constitucionais quanto à distribuição dos ônus da prova, devendo, diante da existência de inadequação, aplicar a dinamização do onus probandi, distribuindo tais ônus em conformidade com a Constituição Republicana Brasileira.

Necessário afirmar, quanto ao artigo 333 e incisos do CPC, que além de consistir em uma norma fechada, rígida e que não tem aptidão para açambarcar todas as hipóteses fáticas existentes em abstrato, adota na distribuição dos ônus probatórios, como anteriormente frisado, dois critérios, sendo um principal e outro secundário que, por si sós, são insatisfatórios para o alcance da finalidade pretendida: o critério da natureza dos fatos e o critério da posição processual das partes em juízo.

Ao lado da necessidade de conferir à distribuição do ônus da prova plena conformidade com os direitos fundamentais e garantias constitucionais, está a necessidade de equilibrar os esforços probatórios, eliminando a excessiva dificuldade de uma das partes no exercício do direito fundamental à prova e, no limite, instrumentalizar o juiz de mecanismos que efetivamente o aproximam da justiça desejada pelas partes e pela própria jurisdição, a partir do momento que a distribuição dinâmica lhe permite uma busca mais efetiva da verdade possível, através da exata adequação dos meios de prova àquela parte que possuir melhor possibilidade de produzi-la.

Evidente que não é um instrumento processual que irá, como num passe de mágica, trazer ao processo a verdade absoluta em todas as hipóteses, contudo irá, indubitavelmente, contribuir para que essa busca seja aperfeiçoada e efetivada por intermédio das próprias partes.

Questão essencial, fundamental, estruturante nesta teorização, sob pena de transformá-la em um instrumento de arbítrio, abusos e autoritarismos judiciais, indesejáveis e já não mais cabíveis em nosso sistema processual civil, é estabelecer critérios e limites teórico-jurídicos quando da aplicação da dinamização do onus probandi. 
Desde já é imprescindível afirmar que não há falar-se em aplicação da dinamização do onus probandi sem motivação, o que feriria o artigo 93, inciso IX da CR, ensejando nulidade insanável do respectivo decisum.

\subsubsection{Dinamização versus inversão do ônus da prova}

Extremamente relevante no contexto do presente trabalho é verificar se existem pontos de congruência e dissenso entre a dinamização do ônus da prova e a inversão do ônus da prova. Ab ovo pode-se firmar com total segurança, desde que observado o rigor técnico-jurídico dos termos, a seguinte premissa: ambos são atos jurídico-processuais distintos.

No direito processual civil positivado há duas regras principais que disciplinam a distribuição do ônus da prova. A regra geral, que institui o sistema tradicional, aplicável na esmagadora maioria das hipóteses fáticas e jurídicas, está consignada no artigo 333, incisos I e II do CPC. ${ }^{265}$ A outra regra, de natureza especial, aplicável em duas hipóteses específicas, todavia comuns na prática jurídica, está positivada no artigo $6^{\circ}$, inciso VIII do Código de Defesa do Consumidor. ${ }^{266}$

A regra geral distribui o ônus da prova da seguinte forma: ao autor da demanda incumbe o ônus de provar o fato constitutivo do direito que alega possuir e, ao réu, incumbe o ônus de provar ou a existência de fato impeditivo, ${ }^{267}$ ou a existência de fato

\footnotetext{
${ }^{265}$ Lei no 5.869 , de 11 de janeiro de 1973 - CPC. Art. 333. O ônus da prova incumbe: I - ao autor, quanto ao fato constitutivo do seu direito; II - ao réu, quanto à existência de fato impeditivo, modificativo ou extintivo do direito do autor. Parágrafo único. É nula a convenção que distribui de maneira diversa o ônus da prova quando: I - recair sobre direito indisponível da parte; II - tornar excessivamente difícil a uma parte o exercício do direito.

${ }^{266}$ Lei $\mathrm{n}^{\circ}$ 8.078, de 11 de setembro de 1990 - CDC. Art. $6^{\circ}$ São direitos básicos do consumidor: VIII - a facilitação da defesa de seus direitos, inclusive com a inversão do ônus da prova, a seu favor, no processo civil, quando, a critério do juiz, for verossímil a alegação ou quando for ele hipossuficiente, segundo as regras ordinárias de experiências; [...]. Vale mencionar ainda a existência de outra regra, no bojo do referido diploma legal, que dispõe de forma rígida, mas diversa da regra geral, a distribuição do ônus da prova: Art. 38. O ônus da prova da veracidade e correção da informação ou comunicação publicitária cabe a quem as patrocina.

${ }_{267}$ Quanto à dificuldade conceitual pertinente à definição de fato constitutivo e fato impeditivo, conferir Título II, seção 2.1.6.1, nota 174 .
} 
modificativo, ou a existência de fato extintivo, relativamente ao direito que o autor da demanda alega ter.

Note-se que o requerido, em momento algum, tem o ônus de provar a existência de qualquer direito seu, ou melhor, qualquer direito autônomo seu, pois sua defesa está, também em âmbito probatório, absolutamente vinculada aos limites objetivos da demanda, que são impostos pela parte autora. Verdade que determinados fatos impeditivos, modificativos e extintivos do direito do autor consistem, substancialmente, em direitos autônomos do requerido. Contudo a apresentação desses tem por objeto direto e precípuo obstar o alegado direito da parte autora e não o reconhecimento e/ou o cumprimento desse direito do requerido apresentado em âmbito defensivo. Em síntese, ao requerido incumbe apresentar fatos, meramente fatos. ${ }^{268}$

Por outro lado, também não lhe é imputado o ônus de provar o fato constitutivo do direito do autor. Essa afirmativa parece óbvia, e realmente é, porém tem relevância teórica conforme adiante será analisado, na distinção entre inversão e dinamização do ônus da prova.

Quanto à regra especial sob análise (artigo 6º, inciso VIII do CDC), esta estabelece duas hipóteses em que o juiz não deve aplicar a regra geral do CPC. Relativamente a essa, uma primeira conclusão faz-se necessária: é uma regra de caráter especial que tem por escopo precípuo facilitar a defesa de um direito material supostamente lesado, reivindicado em juízo. ${ }^{269}$

A primeira hipótese refere-se à verossimilhança da alegação autoral, i.e., adotou-se um critério estritamente processual - endoprocessual - para permitir ao juiz modificar a regra geral. Na segunda hipótese, diferentemente, o legislador adotou um critério extraprocessual, de cunho socioeconômico, o da hipossuficiência. E foi além. Como

\footnotetext{
${ }^{268}$ Vale ressalvar, guardadas as devidas peculiaridades, as hipóteses de reconvenção e de ação de natureza dúplice, bem como ainda, em âmbito de juizado especial cível, de pedido contraposto.

${ }^{269}$ Nesse sentido LUCON, Paulo Henrique dos Santos. Garantia do tratamento paritário das partes. In TUCCI, Garantias constitucionais..., 1999, p. 115. Afirma que essa nova situação jurídica processual (a inversão do ônus da prova) tem estreita ligação com o direito material, na medida em que a finalidade específica da norma é por fim à vulnerabilidade das alegações do consumidor no tocante à demonstração dos fatos constitutivos de seu direito.
} 
critério interpretativo para a expressão hipossuficiência, permitiu ao juiz utilizar as regras ordinárias de experiência. ${ }^{270}$

Em síntese, na primeira hipótese o legislador concedeu ao juiz uma discricionariedade valorativa relativa à análise da existência de verossimilhança dos fatos alegados pelo autor. ${ }^{271} \mathrm{Na}$ segunda hipótese o juiz utilizará para modificar a distribuição do ônus da prova uma regra de experiência ao interpretar, caso a caso, a situação fática e socioeconômica do autor.

Por outra ótica, quiçá mais profunda, verifica-se que um fator externo ao direito processual foi o motivo, a justificativa, para que o legislador modificasse a regra geral do artigo 333 do CPC, i.e., a necessidade de dar ao direito processual um instrumento para equilibrar as desigualdades e, consequentemente, promover a justiça de forma mais efetiva, diante de uma situação socioeconômica de inferioridade fática, não jurídica. ${ }^{272}$

Vale ressaltar que resta ultrapassada a discussão quanto à necessidade de acumulação desses dois critérios para a sua aplicação.

270 DALL'AGNOL JÚNIOR, Antônio Janyr. Distribuição dinâmica dos ônus probatórios. Revista dos Tribunais, ano 90, n. 788, p. 92-107, junho 2001. p. 95-96, sustentando que o CDC rompeu com a visão estratificada do artigo 333 do CPC, afirma que o referido diploma legal, segundo uma leitura realista do que ordinariamente ocorre, não apenas conferiu poderes ao Juiz como o fez admitindo a consideração para com dados que fogem ao controle do legislador. Trata-se, agora, de, no caso concreto, ignorar a distribuição abstratamente prevista na lei processual civil, [...]. A inversão, [...] opera-se ope iudicis, e não ope legis, motivo pelo qual é indispensável o pronunciamento do juiz, independentemente da circunstância de que se cuide de regra de julgamento e da distribuição do encargo de provar.

${ }^{271} \mathrm{Na}$ visão de DALL'AGNOL JÚNIOR, Ibid., p. 96-97, não há como olvidar que à verossimilhança tem recorrido os Juízes que, ampla ou restritamente, aplicam a teoria da carga dinâmica das provas, para solucionar hipóteses de insuficiência de prova. Afirma ainda que a imposição ao Juiz de proferir decisão de inversão, em favor do consumidor, sempre que se evidencie mais fácil ao fornecedor a produção da prova, é exatamente o ponto de aproximação entre a solução positiva brasileira e a denominada teoria das cargas dinâmicas da prova.

${ }^{272} \mathrm{Na}$ essência, não há diferença jurídica, em âmbito de igualdade, entre um consumidor pobre que ajuíza uma demanda ressarcitória em face de uma grande empresa, devidamente assistido pela Defensoria Pública e uma esposa desprovida de bens particulares, pois serviu à família por longos anos, que ajuíza uma demanda de divórcio cumulada com pensão alimentícia, em face do esposo sócio majoritário de uma grande empresa de construção civil, instituída antes do matrimônio, também devidamente assistida pela Defensoria Pública. $\mathrm{Na}$ primeira hipótese incide a regra especial quanto à distribuição do ônus da prova. $\mathrm{Na}$ segunda, em decorrência da matéria, não. 
Diante de tudo isso, verifica-se que no direito processual civil pátrio, a principal regra positivada, que contém duas hipóteses permitindo ao juiz, na sentença, ${ }^{273}$ inverter o ônus da prova, ${ }^{274}$ é a regra consignada no artigo $6^{\circ}$, inciso VIII do Código de Defesa do Consumidor.

Doravante será aberto parêntese, visando discorrer sobre o tema da "inversão" do ônus da prova sob a perspectiva da ausência de regra positivada específica e sua aplicabilidade pela jurisprudência e, ainda, sua aceitação doutrinária. Isso ocorre, em nosso ordenamento, na seara do direito processual trabalhista, sendo pacífica a possibilidade de aplicação da regra insculpida no artigo $6^{\circ}$, inciso VIII do CDC, de forma subsidiária.

No direito processual trabalhista a regra que disciplina a distribuição do ônus da prova está consignada no artigo 818 da CLT. ${ }^{275}$ Todavia, resta pacificada a incidência subsidiária do artigo 333 e incisos do CPC e, como dito anteriormente, do próprio artigo $6^{\circ}$, inciso VIII do CDC.

Essa aplicabilidade se sustenta no entendimento de que as normas que regem as relações de emprego e dissídios coletivos na Justiça do Trabalho não se exaurem no contexto da CLT, inclusive por expressa determinação legal, ${ }^{276}$ motivo este que permite a extração de tantos direitos materiais dos trabalhadores, quanto normas de processo do trabalho de outros arcabouços legais. Os artigos $8^{\circ}$ e 769 da CLT se reportam, respectivamente, a aplicação subsidiária do direito comum e do direito processual comum.

\footnotetext{
${ }^{273}$ Parcela minoritária da doutrina defende que a "inversão" do ônus da prova, com suporte no CDC, deve ser feita em momento anterior à sentença, precisamente até o saneamento da demanda, visando evitar surpresas para a parte onerada. Nesse sentido RODRIGUES, Marcelo Abelha. Elementos de direito processual. São Paulo: RT, 2000. v. 2. p. 187, nota 36; MOREIRA, Carlos Roberto Barbosa. A defesa do consumidor em juízo. Revista de Direito do Consumidor, São Paulo, RT, v. 5, p. 197-198, jan-mar 1993; ALMEIDA, João Batista de. A proteção jurídica do consumidor. São Paulo: Saraiva, 2002. p. 80. Na essência, o divisor de águas dessa divergência situa-se no entendimento teórico que o jurista possui a respeito do fenômeno do ônus da prova: como regra de juízo, como regra de procedimento ou, ainda, aceitando os dois aspectos, mas conferindo a um deles preponderância.

${ }^{274}$ Ver-se-á em seguida que se trata, na realidade, de modificação do ônus da prova e não inversão propriamente dita, motivo pelo qual o referido termo será, doravante, utilizado entre aspas.

${ }^{275}$ Decreto-lei $n^{\circ} 5.452$, de $1^{\circ}$ de maio de 1943. CLT. Art. 818: A prova das alegações incumbe à parte que as fizer.

${ }^{276}$ CLT. Art. 769: Nos casos omissos, o direito processual comum será fonte subsidiária do direito processual do trabalho, exceto naquilo em que for incompatível com as normas deste Título; e Art. $8^{\circ}$ - As autoridades administrativas e a Justiça do Trabalho, na falta de disposições legais ou contratuais, decidirão, conforme o caso, pela jurisprudência, por analogia, por equidade e outros princípios e normas gerais de direito, principalmente do direito do trabalho, e, ainda, de acordo com os usos e costumes, o direito comparado, mas sempre de maneira que nenhum interesse de classe ou particular prevaleça sobre o interesse público.
} 
Tais expressões são tidas como a porta de saída e de entrada para todas as normas de direito privado não integrantes da CLT e da legislação trabalhista especializada, inclusive as normas de proteção ao consumidor, as quais se identificam perfeitamente com as diretrizes fundamentais do direito do trabalho. Nesse particular, afirma-se que o direito trabalhista e o consumerista tem um denominador comum: a hipossuficiência de uma das partes que integram a relação processual.

A regra de distribuição do ônus da prova consignada no artigo 818 da CLT se mantém silente, até porque confeccionada em 1943, quanto à possibilidade ou impossibilidade de modificação do referido ônus quando da aplicação da regra de julgamento.

Assim, a doutrina e jurisprudência ${ }^{277}$ especiais trataram de normatizar ${ }^{278}$ essa lacuna. Desta forma, a "inversão" do ônus da prova disciplinada no Código de Defesa do Consumidor - artigo $6^{\circ}$, inciso VIII -, é aplicada subsidiariamente ao processo do trabalho, na hipótese da presença dos requisitos de verossimilhança das alegações da parte autora ou da hipossuficiência da mesma. "Inverte-se" ainda o ônus da prova quando as provas necessárias para a comprovação do alegado direito do autor se encontrar nas mãos do empregador; quando houver indício da existência de tratamento discriminatório na relação empregatícia $^{279}$ etc. $^{280}$

277 Cf. Súmula 338 do TST (incorporadas as Orientações Jurisprudenciais nºs 234 e 306 da SBDI-1) - Res. 129/2005, DJ 20, 22 e 25.04.2005. JORNADA DE TRABALHO. REGISTRO. ÔNUS DA PROVA. I - É ônus do empregador que conta com mais de 10 (dez) empregados o registro da jornada de trabalho na forma do art. 74, $\S 2^{\circ}$, da CLT. A não-apresentação injustificada dos controles de frequência gera presunção relativa de veracidade da jornada de trabalho, a qual pode ser elidida por prova em contrário. II - A presunção de veracidade da jornada de trabalho, ainda que prevista em instrumento normativo, pode ser elidida por prova em contrário. III - Os cartões de ponto que demonstram horários de entrada e saída uniformes são inválidos como meio de prova, invertendo-se o ônus da prova, relativo às horas extras, que passa a ser do empregador, prevalecendo a jornada da inicial se dele não se desincumbir.

${ }^{278}$ É o que vem ocorrendo com a teoria da dinamização do ônus da prova no direito processual civil brasileiro, ou seja, doutrina e jurisprudência vem aplicando-a reiteradamente.

${ }^{279}$ A posição jurisprudencial e da doutrina é no sentido de que o empregador ou contratante possui uma enorme vantagem na capacidade de produção de provas sobre atitudes discriminatórias, dispõe de total acesso à documentação relativa ao caso, tem acesso a dados fundamentais, dos quais pode muito bem dispor ou omitir em juízo sem a ciência da parte contrária, possui maior capacidade de arregimentar testemunhos (sem contar o notório poder coercitivo sobre eles pelo poder da dispensa), poder econômico para comprovar suas alegações com estatísticas, levantamento de históricos e um grande número de elementos probantes de grande importância.

${ }^{280}$ Será visto adiante que, na realidade, se trata de hipóteses de dinamização do ônus da prova e não de inversão. 
Apresentado o assunto sob um enfoque específico e na esfera do direito processual trabalhista, insta fechar o parêntese e retornar ao objeto central desta seção e ao artigo 333 e incisos do $\mathrm{CPC}^{281}$

Etimologicamente, inverter vem do latim invertere e significa mudar a ordem de, dispor de maneira contrária ao normal. O vocábulo inverter, em nossa língua, significa alterar, mudar, trocar, virar ao sentido oposto ao natural, trocar a ordem em que estão colocados. $^{282}$

Em um simples raciocínio de lógica, depreende-se que a regra normal e geral quanto à distribuição do ônus da prova, estabelece que ao autor incumbe o ônus de provar o fato constitutivo de seu alegado direito.

Sendo essa a normalidade, a inversão desse ônus, ou seja, a sua alteração, troca, virada ao sentido oposto ao natural, troca da ordem em que está colocada, implica obrigatória e racionalmente concluir que caberia à parte requerida provar os fatos constitutivos do alegado direito do autor. ${ }^{283}$

Utilizando o método da exemplificação, insta verificar a correção da afirmativa supra. Para tal, foi adotada uma demanda na qual um consumidor hipossuficiente, na posição de autor, requereu a devolução do produto adquirido, sob a alegação de existência de defeito insanável. Aplicando a regra geral do CPC, o ônus da demonstração da existência de defeito insanável caberia ao autor. Aplicando a regra especial do CDC, i.e., a "inversão" do ônus da prova, é possível verificar dois desdobramentos. Na doutrina e jurisprudência pátria majoritárias, essa "inversão" significa que o requerido passa a ter o ônus de provar que o produto adquirido pelo autor não tem o alegado defeito insanável. Em outras palavras, o requerido deverá provar o fato desconstitutivo/ impeditivo do alegado direito do autor, consistente na inexistência de defeito insanável. Aplica-se aqui a seguinte fórmula de lógica jurídica: A $x$ R [fda - fma - fea $]=S f A$, ou seja, a fórmula da

\footnotetext{
${ }^{281}$ A referência do fenômeno da "inversão" do ônus da prova sob a seara do direito processual trabalhista objetivou comprovar que em nosso ordenamento jurídico (doutrina e jurisprudência), ainda que em face de matéria dita como especial, permite uma espécie de modificação do ônus da prova sem qualquer previsão legal, adotando apenas a técnica da interpretação.

${ }^{282}$ Cf. MICHAELIS, Dicionário..., 2002, p. 436; FERREIRA, Pequeno dicionário..., [19--]. Nesse sentido LUCON, Garantia do tratamento paritário..., 1999, p. 114.

${ }^{283}$ Nesse sentido ARENHART, Ônus da prova..., 2009, p. 337 e 340.
} 
dinamização do ônus da prova. ${ }^{284}$

O segundo desdobramento corresponde à essência e racionalidade do termo "inversão", aquilo que deveria ser seguido caso o termo sob enfoque - "inversão" do ônus da prova - fosse o termo técnico-jurídico adequado à correspondente hipótese. Seguindo à risca o significado do vocábulo inversão, caberia ao requerido, em sentido oposto ao natural, trocando a ordem em que a regra geral está colocada, demonstrar que o produto adquirido pelo autor apresenta o defeito insanável alegado, ou seja, provar o fato constitutivo do direito do autor. Aqui se inverte quem deve provar o fato e o próprio fato a ser provado.

Possível concluir, assim, que o termo "inversão" do ônus da prova não é o termo técnico-jurídico adequado à hipótese, ${ }^{285}$ pois não corresponde ao sentido de vernáculo, nem o próprio de nossa língua, nem de sua origem latina.

Na realidade, a doutrina e a jurisprudência, ${ }^{286}$ desde sua edição, ao interpretar e aplicar de forma correta e lógica os termos dessa regra especial consignada no CDC, ao

\footnotetext{
${ }^{284}$ Cf. notas 250 e 251 deste.

${ }^{285}$ Nesse sentido LUCON, Garantia do tratamento paritário..., 1999, p. 114. O jurista é categórico ao advertir que a denominada inversão do ônus da prova, na realidade, nada inverte. Para o autor, inversão do ônus da prova significa dispensa da parte de fazer prova de algum fato por ela alegado, em determinadas situações. Nessas, dispensa a lei que o demandante faça prova do fato constitutivo de seu direito. Ainda, ARENHART, Ônus da prova..., 2009, p. 337. Também é enfático ao afirmar que, na realidade, não existe caso de inversão própria do regime do ônus da prova, [...]. Nenhuma hipótese existente no direito brasileiro contempla semelhante previsão, de modo que não se deve falar, ao menos propriamente, em "inversão do ônus da prova".

${ }^{286}$ STJ. Informativo $\mathrm{n}^{\circ}$ 0412. Quarta Turma. PROVA. ÔNUS. INVERSÃO. PÍLULAS DE FARINHA. A Turma proveu em parte o recurso, entendendo que, no mérito, quanto às exceções à regra geral acerca da inversão do ônus da prova (art. 333 do CPC), em se tratando de relações consumeristas, o art. $6^{\circ}$, VIII, do CDC não tem aplicação ope legis, mas ope iudicis, a saber, cabe ao juiz redistribuir a carga probatória conforme o caso concreto, pois não basta que a relação seja regida pelo $\mathrm{CDC}$, é indispensável a verossimilhança das alegações do consumidor ou sua hipossuficiência. Doutrinariamente, é cabível tal inversão do ônus da prova para facilitar sua produção por quem detém melhores condições, diante da possibilidade de o réu produzir menos penosamente eventual prova desconstitutiva do direito do autor. Questionou-se se essa inversão realizada pelo Tribunal $a$ quo, efetivamente, facilitou a elucidação dos fatos narrados pela consumidora, ou se, pela impossibilidade de sua comprovação, somente cabível por presunção, como no caso, significou a automática procedência do pedido. Entretanto, dada a controvertida gravidez da autora por ineficiência do uso das chamadas "pílulas de farinha" como anticoncepcional sem o princípio ativo, não é possível a pretendida inversão do ônus da prova, mormente em apelação, já que abrange somente os fatos narrados na inicial, sem o nexo de causalidade entre os fatos e o dano sofrido. Daí descabe atribuir à recorrente, por presunção e sem a devida comprovação, a responsabilidade por toda gravidez das usuárias de seus medicamentos, ainda que eficazes, sendo inafastável a improcedência do pedido. Precedentes citados: REsp 716.386-SP, DJe 15/9/2008; REsp 707.451-SP, DJ 11/12/2006; REsp 883.612-ES, DJe 21/9/2009; AgRg no REsp 1.095.663-RJ, DJe 17/8/2009, e REsp 881.651-BA, DJ 21/5/2007. REsp 720.930-RS, Rel. Min. Luis Felipe Salomão, julgado em 20/10/2009.
} 
invés de "inverter", dinamizam o ônus da prova, com permissão legal do legislador, nos casos especificados e diante dos requisitos determinados pela lei, e, em alguns outros casos, como os pertinentes à Justiça do Trabalho, utilizando as normas de interpretação extensiva.

Em síntese, quando se aplica a teoria da dinamização do ônus da prova, não se modifica a estrutura "sujeito - fato a ser provado". O fato constitutivo a ser demonstrado continua atrelado ao autor e o fato impeditivo, modificativo, extintivo do direito do autor a ser provado, continua atrelado ao requerido.

A dinamização na essência estabelece de forma diversa, dinâmica, a ordem de primazia na produção da prova, gerando efeitos quanto às consequências da inatividade probatória, não invertendo absolutamente nada, mantendo-se, ad abundantiam, o fato constitutivo a ser provado atrelado ao autor e o fato impeditivo, modificativo, extintivo do direito do autor a ser demonstrado atrelado ao requerido.

A dinamização não modifica o sujeito, i.e., o fato impeditivo, modificativo, extintivo do direito do autor não passa a ser incumbência do autor, o que seria teratológico, continuando a ser incumbência do requerido. Por outro lado, também não modifica o fato a ser provado, i.e., o fato constitutivo continua na incumbência de ser provado pelo autor e o fato impeditivo, modificativo, extintivo do direito do autor continua na incumbência de ser provado pelo requerido. Eis a fórmula lógico-jurídica: DINAMIZAÇÃO DO ÔNUS DA PROVA $=$ A [fca $x$ R [fda - fma - fea ${ }^{287}$

A “inversão" do ônus da prova, na justeza de seu termo, ao revés, modifica tanto quem deve demonstrar determinado fato, bem como o fato a ser demonstrado: o autor passaria a ter a incumbência de provar o fato que era da incumbência do requerido e o requerido o fato que era da incumbência do autor, o que comprova, além de tudo, uma absoluta irracionalidade. Eis a fórmula lógico-jurídica: INVERSÃO DO ÔNUS DA PROVA = A [fda - fma - fea] x R [fca]. ${ }^{288}$

\footnotetext{
${ }^{287}$ Cf. notas 249 e 250 deste.

${ }^{288}$ Cf. notas 250 e 251 deste.
} 
Ademais insta ressaltar que, independentemente das regras de distribuição do ônus da prova, ambas as partes, caso queiram, podem produzir toda e qualquer prova, não havendo óbice, exceto o pertinente ao interesse-necessidade e quanto à licitude. Vale lembrar ainda que o direito à prova é amplo e limitado somente por regras constitucionais, v.g., vedação da prova ilícita, mas sua produção sofre limitações de ordem processual justamente pelo interesse-necessidade. ${ }^{289}$ Nada impede, em tese, que o próprio autor prove um fato total ou parcialmente modificativo de seu direito, bem como que o réu prove um fato total ou parcialmente constitutivo do direito do autor.

Voltando ao exemplo acima mencionado, o ônus da demonstração da existência de defeito insanável que caberia ao autor e deveria ser provado com primazia, com a regra especial do artigo $6^{\circ}$, inciso VIII do CDC, que na realidade deve ser interpretada como dinamização do ônus da prova e não como "inversão", o que, aliás, sempre foi feito pela doutrina e jurisprudência, continua a ser do autor. Contudo, perde a primazia para o requerido que deverá, antes deste, provar a inexistência do defeito insanável alegado pelo autor.

É essa a dinâmica, científica e racional, das regras processuais relativas à atividade probatória, especificamente quanto à distribuição entre as partes dessa atividade e dos riscos da respectiva inatividade.

Estabelecidas, dessa forma, as diferenças fulcrais entre a dinamização do ônus da prova e a "inversão" do onus probandi disciplinada pela regra especial do artigo $6^{\circ}$, inciso VIII do CDC.

\subsubsection{Atuação do juiz e das partes: novo paradigma}

A teoria da dinamização do ônus da prova traz consigo, projetando-a no sistema processual civil pátrio, um novo paradigma na atuação procedimental e jurisdicional do Estado-juiz. Quanto às partes, esse novo paradigma se expressa de forma mais efetiva, no

${ }^{289}$ Cf. afirmativas sobre o fator interesse e suas limitações no Título II, seção 2.1.4 et seq. 
aumento de ética de suas condutas no bojo do processo, principalmente e em um primeiro momento, diretamente na fase probatória.

Isso quer dizer que a postura do Estado-juiz diante da matéria deve mudar radicalmente. De um proceder inerte, para um proceder ativo. Da espera mórbida pela atividade probatória das partes, de acordo com o critério estabelecido em abstrato, para o ativismo responsável na estruturação da atividade da produção da prova pelas partes em juízo.

O ativismo do magistrado, especificamente em relação à teoria da dinamização do ônus da prova, se evidencia de forma veemente quando este cumpre de forma plena e exaustiva seu dever de informação às partes quanto à possibilidade de sua aplicação no momento oportuno, modificando o cenário probatório e agindo pedagogicamente ${ }^{290}$ na consciência das partes, conforme será adiante detalhado.

Esse proceder ativo tem ainda, como uma das motivações e, porque não dizer, justificativa, o dever do Estado-juiz de buscar a verdade possível. Não se ambiciona e não se defende, o que seria utopia ou até mesmo demagogia, diante da realidade estruturaladministrativa do Poder Judiciário brasileiro, pretender que o Estado-juiz buscasse a verdade real no processo civil. ${ }^{291} \mathrm{O}$ que se almeja, por ser dever do Estado, ao trazer para si o monopólio da justiça, da pacificação social, é que ele atue de forma efetiva na busca da verdade possível. A satisfação com a verdade formal consiste em uma cômoda ficção jurídica que vai de encontro ao dogma da justiça, refletindo uma efetiva busca por uma verdade qualquer, na maioria das vezes, uma ausência de verdade.

A teoria da dinamização do ônus da prova operacionaliza um parodoxo de extrema relevância para a ciência jurídica, expresso na possibilidade do aumento de certeza versus possibilidade de diminuição das desigualdades na ausência de certeza fática.

\footnotetext{
290 DINAMARCO, A instrumentalidade..., 2008, p. 191-193, ao afirmar que a educação é um dos escopos instrumentais do processo e da jurisdição, leciona que há uma relação direta entre educação e confiança, na medida em que o exercício da jurisdição seja apto a conscientizar para direitos e obrigações.

${ }^{291}$ Nem no processo penal pátrio esse dogma da verdade real é, verdadeiramente, realizado.
} 
Ao mesmo tempo em que sua estrutura teórica implementa, pelas mãos dos sujeitos do processo, um aumento da certeza fática, provocada pela possibilidade do desonerado tornar-se onerado, o que leva a ambos produzirem todas as provas possíveis, distribui de forma mais justa a eventual ausência dessa mesma certeza, equilibrando as forças e as armas em âmbito probatório.

Ainda, ao mesmo tempo em que distribui de forma mais justa a ausência de certeza, pois ao aplicar a teoria o juiz estará onerando aquele que tinha mais facilidade em produzir a prova, combatendo a desídia dolosa, a má-fé, o abuso de direito, a manipulação estratégica das regras processuais probatórias e do próprio instrumento em prol de vitórias injustas e, na maioria das vezes, em proteção daqueles que detém o poder político e/ou o poder econômico, tem a virtude de conscientizar as partes, mudando seus comportamentos no bojo do processo, e até mesmo fora dele, no sentido de que a verdade não pode e não deve ser omitida e que, se antes, a regra tradicional da distribuição do ônus da prova tutelava essa omissão em detrimento da verdade, doravante, tal teoria elimina essa possibilidade.

E aí se ressalta o importante papel do juiz, pois incumbe a ele identificar essas desigualdades e aplicar a teoria da dinamização do ônus da prova. O processo não pode ser utilizado para fins menores. O Estado-juiz tem que renovar, dia-a-dia, seu compromisso com os fins maiores que legitimam sua própria existência.

A dinamização do ônus da prova é, indubitavelmente, um instrumento eficaz e efetivo nessa busca da verdade possível, legitimando ainda mais a atividade jurisdicional, por intermédio do processo.

Consciente disso, o Estado-juiz, diante do caso concreto, irá averiguar, detendo-se aos fatos apresentados pelas partes, às circunstâncias específicas de cada parte, à natureza da demanda, se deve aplicar a regra positivada do artigo 333 e incisos do CPC ou se deve aplicar a teoria da dinamização do ônus da prova, ou ainda, fazê-lo de forma mista, em conformidade com os fatos apresentados. Dessa forma, resta assentado que não será em todos os casos concretos que se dará a distribuição dinâmica dos ônus probatórios, podendo o Estado-juiz seguir a distribuição rígida fixada em lei pelo artigo supra mencionado. 
$\mathrm{Na}$ distribuição dinâmica, ad abundantiam, como a distribuição do ônus da prova ocorrerá sempre diante do caso concreto, caso a caso, de acordo com as circunstâncias específicas apresentadas pelas partes, o juiz passa a ser protagonista, ${ }^{292}$ decidindo, fundamentadamente, a quem incumbirá os ônus probatórios. Não se aceita mais uma passividade mórbida e maléfica do juiz. Sua atuação torna-se, desta forma, imprescindível para o descobrimento da verdade possível, para a realização da justiça, para a efetividade do processo, para o alcance do resultado pretendido, tanto sob a ótica do direito processual quanto do direito material.

Doravante, diante da necessidade de esculpir a teoria da dinamização do ônus da prova em harmonia com o ordenamento jurídico pátrio, o objetivo consistirá em estabelecer cientificamente a estrutura dessa teorização.

\footnotetext{
${ }^{292}$ Nesse sentido ARENHART, Ônus da prova..., 2009, p. 362-363. Enfatiza o jurista que, de fato, ninguém melhor que o magistrado para saber quem tem melhores condições de produzir certa prova e, portanto, quem deve ser prejudicado pela dúvida judicial. A determinação anterior da distribuição destas cargas não dá conta da riqueza da realidade, permitindo, com maior facilidade, o cometimento de injustiças na aplicação desavisada da consequência na desatenção do ônus da prova. Já a distribuição dinâmica deste ônus, a par de dispensar toda a digressão aqui feita, amolda o processo mais perfeitamente à realidade a ser examinada, permitindo resultados mais adequados e aperfeiçoando o processo.
} 


\subsubsection{ELEMENTOS ESTRUTURAIS}

Os elementos estruturais de toda teoria guardam relevância ímpar, pois como a própria terminologia indica, são justamente os elementos que a sustentam, como pilares de uma construção. Estes, uma vez reunidos, compõem o seu todo e permitem o surgimento de algo novo, com forma e conteúdo próprios.

Em efeito, a conjugação dos elementos estruturais da teoria da dinamização do ônus da prova lhe concede, ainda, eficácia e validade teórica e prática no sistema jurídico.

A teoria da dinamização do ônus da prova apresenta quatro elementos estruturais fundamentais: os requisitos para a sua aplicabilidade, o dever de informação do magistrado às partes, o momento de sua aplicabilidade e os limites de sua aplicabilidade.

Não obstante, outros elementos serão apresentados, conferindo à teoria completude como, v.g., a relação entre a dinamização e poder-dever, fundamentação dessa e a sentença que a aplica, bem como as consequências de ordem prática relativamente a sua utilização em nosso ordenamento jurídico que, ao mesmo tempo, dada a sua relevância, também justificam a sua aplicação.

\subsubsection{Requisitos de aplicabilidade da dinamização do ônus da prova}

\subsection{Primeiras linhas}

Estabelecer os requisitos que permitem a aplicabilidade da dinamização do ônus da prova e, consequentemente, o campo de incidência da teoria no direito processual civil é tarefa árdua, pois se trata de um universo infinito de hipóteses.

Dessa forma, não faz parte dos objetivos deste trabalho estabelecer, numerus clausulus, as hipóteses de cabimento de aplicação da dinamização, o que seria tão 
impossível quanto determinar todos os fatos do mundo real suscetíveis de ser levados a juízo. Ademais, se incorreria no mesmo equívoco do legislador ao estabelecer a regra rígida e em abstrato do artigo 333 e incisos do CPC.

O propósito, doravante, é identificar e fixar os requisitos de ordem programática da teoria, estabelecendo assim parâmetros gerais, porém determinados, baseados em fundamentos empíricos, alguns deles inclusive corroborados pela própria jurisprudência pátria.

Faz-se necessário, entretanto, apresentar novamente alguns elementos conceituais visando possibilitar uma compreensão e assimilação mais precisas em relação às próximas premissas que serão estabelecidas.

Será adiante demonstrado e fixado, apesar de já ter sido anteriormente mencionado no Título I deste trabalho, que a teoria da dinamização do ônus da prova, apesar de ser efetivamente aplicada na sentença, apresenta como elemento condicionante a sua aplicação, o cumprimento do dever de informação do magistrado às partes, primordialmente na fase procedimental do saneamento.

Uma vez realizado tal ato, ${ }^{293}$ as partes passam a ter plena ciência que o magistrado, naquele caso concreto, poderá ao sentenciar, dinamizar o ônus da prova de forma diversa da regra geral rígida e aplicar a regra de julgamento pertinente. Na prática, e já adiantando um dos efeitos desta teoria, nesse caso concreto, ambas as partes se esforçarão para provar os respectivos fatos alegados, ou seja, a parte autora o fato constitutivo de seu direito e o requerido o fato impeditivo, modificativo e extintivo do direito do autor. Em efeito, a inércia dolosa daquela parte beneficiada pela regra fixa do ônus da prova desaparecerá, diante da já notificada possibilidade de dinamização do ônus da prova.

\footnotetext{
${ }^{293}$ O dever de informação mencionado possui importância vital para o contexto da teoria da dinamização do ônus da prova, sendo condição sine qua non para sua aplicação quando do proferimento da sentença. A aplicação da dinamização sem o cumprimento desse dever gera nulidade insanável.
} 
A teoria da dinamização do ônus da prova não tem por objeto a distribuição da responsabilidade da produção da prova. ${ }^{294}$ Não se trata de determinar a qualquer das partes que essa ou aquela produza determinada prova diretamente. Isso é função do ônus da prova subjetivo. Em outras palavras, aplicando a teoria da dinamização o magistrado, indiretamente e, somente indiretamente, irá instigar, induzir, que determinada parte produza essa ou aquela prova, sob pena de ao optar por não fazê-lo, poder eventualmente sofrer as consequências da sua própria inércia.

Outro fator importante é que o magistrado poderá dinamizar o ônus da prova de forma parcial, dividindo, ainda que em medidas diferentes, a responsabilidade da inércia probatória entre ambas as partes, respeitando sempre o critério da classificação dos fatos que devem ser provados: constitutivo, impeditivo, modificativo e extintivo.

Visto isto, necessário retornar ao propósito desta seção.

Uma premissa que não se pode perder de vista e, portanto, que deve ser estabelecida prioritariamente, é a de que o magistrado, ao aplicar a teoria da dinamização do ônus da prova, estará, total ou parcialmente, afastando a incidência do disposto no artigo 333 e incisos do CPC, ou seja, estará afastando a aplicação de uma norma legal. Mas o fará respaldado na própria Constituição Republicana Brasileira, no princípio constitucional e fundamental do processo civil expresso na cláusula due process of law, no princípio constitucional da inafastabilidade da jurisdição, no dogma maior do direito que é a justiça. $^{295}$

Os requisitos de aplicabilidade da dinamização do ônus da prova consistem, assim, em pressupostos que concedem permissão ao magistrado, diante das circunstâncias específicas de cada caso concreto, observando sempre o contexto da estrutura teórica dessa, distribuir dinamicamente o ônus da prova, quando do proferimento da sentença, mantendo-se fiel ao conceito de regra de julgamento. ${ }^{296}$

\footnotetext{
${ }^{294}$ Essa terminologia foi utilizada pelo legislador pátrio no Projeto de Lei que visava instituir o Código de Processo Civil Coletivo. Cf. Título IV, seção 4.3.

${ }^{295}$ Nesse sentido ARENHART, Ônus da prova..., 2009, p. 357. Afirma que o art. 333 do diploma processual é norma infraconstitucional que, portanto, deve conjugar-se ao texto da Lei Maior.

296 MITIDIERO, Colaboração no processo..., 2009, p. 128-130, enfatiza que a dinamização do ônus da prova, deslocando-se o encargo de provar daquele fixado a priori pela legislação, requer a demonstração de
} 
O requisito mais amplo, no sentido de açambarcar em seu bojo outros requisitos que dele derivam, consiste, como em uma das faces de uma mesma moeda, na real impossibilidade ou dificuldade da parte onerada de produzir prova e, na outra face desta, na maior facilidade e possibilidade da outra parte em produzir prova. ${ }^{297}$

\subsection{Impossibilidade de produção da prova}

A impossibilidade na produção da prova pela parte autora, a priori onerada pela regra do artigo 333, inciso I do CPC, não necessariamente implica facilidade da produção da prova pela parte contrária.

A dificuldade ou impossibilidade na produção de determinada prova por uma parte não guarda nexo causal obrigatório pertinente à facilidade e possibilidade de produção dessa prova pela parte contrária. Esse nexo causal existe em âmbitos gerais, porém não em todos os casos concretos, sendo marcado pelo caráter da eventualidade. Diante disso, se pode afirmar que nem toda hipótese que configure dificuldade ou impossibilidade na produção da prova significa, necessariamente, facilidade e possibilidade para a outra parte quanto à sua produção.

Assim, pode-se estabelecer como primeiro requisito para a aplicação da teoria sob enfoque a efetiva dificuldade ou impossibilidade da parte onerada em produzir determinada prova do fato alegado. A efetiva dificuldade ou impossibilidade pode ser

determinadas condicionantes. Para o autor em questão, não se pode dinamizar o ônus da prova sem que haja grave ofensa à ordem jurídica justa. Assim estabelece para sua aplicação condicionantes materiais e processuais. Na perspectiva material, em síntese, menciona a inadequação do artigo 333 do CPC e a maior facilidade de uma das partes em produzir a prova. Na perspectiva processual fixa como condicionantes a motivação da decisão e a atribuição do ônus da prova com a correlata oportunidade de provar. Defende que a dinamização se dê preferencialmente na audiência preliminar (artigo 331, CPC), mas não vê óbice que o juiz a dinamize em momento posterior desde que reabra a fase instrutória, a fim de não se ferir o direito fundamental à prova no processo civil. Nesse particular, há que se divergir frontalmente desta posição, pois dentre outros motivos, estar-se-á quebrando o dogma do ônus da prova como regra de juízo. Cf. seção 3.2.2.3 e 3.2.2.3.2, deste capítulo, onde foi enfrentada a presente discussão teórica.

297 ROSENBERG, La carga..., 2002, p. 94, em relação ao direito processual alemão vigente na primeira metade do século passado, já defendia a possibilidade do tribunal admitir a prova da exceção antes da prova do fundamento da demanda, v.g., quando aquela prova pudesse ser produzida facilmente, enquanto a comprovação do fundamento da demanda requeresse provas extensas. 
satisfatoriamente conceituada como sendo uma dificuldade concreta e de difícil transposição ou mesmo intransponível, pela respectiva parte. ${ }^{298}$

Essa efetiva dificuldade ou impossibilidade, por sua vez, pode derivar da: a) ausência de condições fáticas na obtenção da prova, uma vez que prova não obtida não pode ser produzida; b) da ausência de condições econômicas da parte interessada, inserindo-se perfeitamente neste contexto o conceito de desigualdade econômica; c) da ausência de condições técnicas da parte interessada, inserindo-se perfeitamente neste contexto o conceito de desigualdade técnica.

Insta ressaltar que o nosso legislador processual civil já havia considerado expressamente, no parágrafo único, inciso II do artigo 333 do CPC, esse requisito da excessiva dificuldade, ou seja, já havia atentado para sua importância em âmbito probatório, ao estabelecer a nulidade da convenção entre as partes quando essa visar à modificação do critério tradicional de distribuição do ônus da prova, implicando um efetivo impedimento para a produção da prova e, assim, para o exercício de seu direito. Não o previu, todavia, para a ocorrência desse fato, i.e., a excessiva dificuldade, quando da distribuição rígida do ônus da prova, justamente por considerá-la perfeita e isenta de desigualdades. $^{299}$

Como se fosse o verso de uma mesma folha de papel, outro requisito para a aplicação da teoria sob enfoque, conexo ao requisito anterior, consiste na efetiva facilidade $^{300}$ da parte em produzir determinada prova que, a priori, diante da regra geral, incumbe à parte ex adversa.

Nessa seara da maior facilidade de produção da prova, pode-se inserir também a daquela parte ex adversa que tenha maiores e melhores condições de produzir provas

\footnotetext{
${ }^{298}$ Essa conceituação se aproxima do conceito de prova diabólica, a qual será oportunamente analisada.

${ }^{299}$ No direito italiano existe regra idêntica, expressa no artigo 2698 do Código Civil. TROCKER, Processo civile e costituzione..., 1974, p. 723, afirma que esse dispositivo retrata a relevância constitucional do direito de ação e de defesa. Todavia, no ordenamento jurídico alemão, como não existe uma norma expressa nesse sentido, a jurisprudência utiliza o conceito de boa-fé para tutelar a parte economicamente e socialmente mais fraca diante do perigo de certas cláusulas contidas nas formas modernas de contratação de massa, i.e., nos contratos de adesão.

${ }^{300}$ A priori trabalha-se com a idéia de que efetiva facilidade seria correspondente à facilidade fática, no mundo real, tanto na obtenção da prova quanto na sua produção. Ex. documento na posse do requerido etc.
} 
capazes de demonstrar a inocorrência de futura violação do direito. ${ }^{301}$

Tudo até aqui especificado pode ser sintetizado na existência de efetiva desigualdade entre as partes, compreendendo desigualdades de várias ordens, inclusive financeiro-econômica.

Essa desigualdade pode desaguar em uma outra vertente, consistente na necessidade de produção de prova complexa.

Outra premissa a ser estabelecida é que a análise da existência dos requisitos acima mencionados, bem como de algum outro não evidenciado até então, mas que coaduna e guarda nexo como as mesmas justificativas, ${ }^{302}$ deve ser feita pelo magistrado, caso a caso, circunstância por circunstância, especificidade por especificidade.

Os requisitos de aplicabilidade da teoria da dinamização dos ônus probatórios, anteriormente evidenciados, não precisam co-existir. Diante disso, basta que o Estado-juiz evidencie a existência e presença no caso concreto de apenas um deles para tornar possível a aplicação da dinamização do ônus da prova.

\subsection{Desigualdade econômico-financeira}

A doutrina brasileira se deparou com a questão relativa à inferioridade socioeconômica $^{303}$ de uma das partes, ao buscar uma definição para o termo

\footnotetext{
${ }^{301}$ Nesse sentido ARENHART, Ônus da prova..., 2009, p. 358.

302 Direitos constitucionais e garantias fundamentais à ordem jurídica justa, à igualdade e à prova; princípio constitucional e fundamental do processo civil expresso na cláusula due process of law; metodologias contemporâneas da instrumentalidade do processo e do processo cooperativo (visão solidarista do processo); princípio geral e universal expresso no dogma maior do direito que é a justiça. Cf. Título III, seção 3.3.2 et seq.

303 BARBOSA MOREIRA, José Carlos. La igualdad de las partes en el proceso civil. Temas de direito processual: $4^{\text {a }}$ série. São Paulo: Saraiva, 1989. p. 73 e 74, lembra que o fator mais frequente, talvez o mais grave de disparidade entre as partes, é o econômico, apesar de desníveis sociais e culturais também diferenciarem as partes, principalmente quando associados ao poder econômico. O processualista afirma ainda que os litigantes habituais gozam sobre os litigantes eventuais todas as vantagens inerentes à produção de provas. Assim, a desigualdade material entre as partes introduz no aparato da Justiça uma deformação contra a qual o ordenamento deve reagir com energia. É dever do legislador, segundo o referido autor, criar
} 
hipossuficiência, na seara do Código de Defesa do Consumidor. Não convém aqui repetir essa discussão, muito menos adentrar no mérito do argumento e entendimento que acabou prevalecendo em nossos dias. O que realmente interessa é analisar essa desigualdade sob o prisma de requisito de aplicação da teoria da dinamização do ônus da prova.

As expressões desigualdade socioeconômica, hipossuficiência econômica, apesar de clássicas na literatura jurídica, são eivadas de dubiedades e sentidos múltiplos que fogem ao interesse investigativo do jurista e, não raro às vezes, o conduz a equívocos de cunho ideológico que acabam contaminando negativamente a atividade jurisdicional, inclusive o próprio princípio da imparcialidade do juiz.

O objeto central, a essência desta questão para a ciência jurídica, não é distinguir a pessoa milionária, física ou jurídica, da miserável. O que realmente deve ser analisado sob o âmbito da ciência jurídica é a capacidade econômico-financeira de todo cidadão de ingressar em juízo e participar efetivamente de todos os atos processuais necessários à defesa de seus direitos materiais e também processuais, quer no polo ativo ou passivo.

Isso conduz, de imediato, à análise da capacidade econômico-financeira do jurisdicionado de pagar as custas, emolumentos, taxas, enfim, quaisquer despesas exigidas por lei, seja na fase inicial da demanda, seja, eventualmente, durante o transcorrer do procedimento, o que tem implicações diretas no direito constitucional do amplo acesso à justiça.

Quanto à desigualdade econômico-financeira como requisito à aplicação da teoria da dinamização do ônus da prova, deverá o magistrado analisar a capacidade econômicofinanceira do jurisdicionado quanto à produção da prova necessária e essencial para a solução da respectiva demanda. Assim, a utilização deste requisito fica adstrita àquelas provas cuja realização dependa de pagamento relativo a sua respectiva execução, sendo a mais comum a produção de prova pericial. 
Em efeito, toda vez que ficar demonstrado nos autos de forma indubitável, ${ }^{304}$ que a parte onerada na produção da prova, não tem capacidade econômico-financeira de produzir a prova essencial à solução demanda, ou seja, do fato constitutivo de seu direito, para o autor, deverá o juiz, com fundamento neste requisito, aplicar a teoria da dinamização do ônus da prova, imputando assim à parte com efetiva capacidade econômico-financeira o ônus da prova e, consequentemente, de sua produção no caso concreto, sob de pena de, ao sentenciar, utilizar a regra de juízo em desfavor da respectiva parte onerada, caso se mantenha inerte.

Pode ocorrer que a situação econômica da parte autora não configure estado de pobreza ensejadora da aplicação da Lei $\mathrm{n}^{\circ} 1.060 / 50$, entretanto, a impossibilite de arcar com as despesas oriundas da produção de determinada prova.

Importa mencionar que a mera determinação judicial à parte com efetivo potencial econômico-financeiro para arcar com as despesas da produção da prova, sem aplicar a teoria da dinamização do ônus da prova, não resolve o problema, ao revés, o potencializa, pois o ônus da ausência ou insuficiência da prova ainda recairia à parte que não possui a citada capacidade. Dessa forma, estará o Poder Judiciário atuando no sentido de desequilibrar, ainda mais, as armas, violando, em efeito, o princípio da paridade de armas entre as partes. $^{305}$

Não se pode esquecer, bem como sustentar sob pretexto algum, inclusive o da aplicação da teoria da dinamização do ônus da prova, ao buscar equilibrar as forças entre as partes, diante da evidente desigualdade econômica de uma delas, que o magistrado crie para a outra parte uma despesa, um custo excessivo, além de seu potencial econômicofinanceiro, tornando assim a produção dessa prova efetivamente impossível, dando ensejo

\footnotetext{
${ }^{304}$ A incidência deste requisito da desigualdade econômico-financeira da parte onerada na produção da prova para fins de aplicação da teoria da dinamização do ônus da prova, i.e., a real ausência de capacidade de arcar com as despesas da prova não deve ser abstraída pelo magistrado por presunções ou por regras de experiência, devendo ser sempre comprovada.

${ }^{305}$ Em sentido semelhante, mas analisando hipóteses diversas, o STJ firmou o entendimento de que a "inversão" do ônus da prova não pode implicar imputação ao fornecedor do custo pela prova pericial. Cf. $3^{\mathrm{a}}$ Turma. AgRg no REsp. 1056858/DF. Rel. Min. Massami Uyeda. DJ 21.10.08; 2a Turma. AgRg no REsp. 1042919/SP. Rel. Min. Humberto Martins. DJ 31.03.09; $1^{\mathrm{a}}$ Turma. REsp. 1073688/MT. Rel. Min. Teori Zavascki. DJ 20.05.09.
} 
a uma verdadeira prova diabólica decorrente da ausência de condições econômicofinanceiras de arcar com as despesas da produção da prova.

Este requisito somente deve ser utilizado como fundamento para aplicação da teoria da dinamização do ônus da prova quando uma das partes, efetivamente, possuir potencial econômico-financeiro para produzir a prova necessária e essencial, sem que isso implique desequilíbrio reverso, i.e., em desigualdade econômica reversa.

Recorrendo à clareza dos exemplos, uma vez que reduz a extensão imaginária da hipótese, fica fácil visualizar a circunstância ora trabalhada. Seria aplicável a teoria, com suporte neste requisito, em uma demanda judicial na qual a parte requerida, uma grande empresa com ações em bolsa de valores, o que torna flagrante seu potencial econômicofinanceiro, fosse demandada por uma pessoa física cuja receita mensal girasse em torno de 05 salários mínimos, sendo que para a produção da prova essencial à solução da demanda, requerida pela parte autora, seria necessário o pagamento de um perito cujos honorários foram fixados em $\mathrm{R} \$ 20.000,00$ (vinte mil reais). Neste caso hipotético, não há falar-se em desigualdade econômica reversa.

Abstrai-se ainda do exemplo acima que não seria hipótese de aplicação da Lei 1.060/50, uma vez que a citada parte autora não se enquadra, em tese, no conceito de pobreza para os fins de ser-lhe concedida a assistência judiciária gratuita. ${ }^{306}$

Não obstante o acima afirmado quanto à criação de desigualdade econômicofinanceira reversa, o magistrado deverá ainda averiguar, antes de aplicar a teoria da dinamização do ônus da prova com fulcro neste requisito, uma vez que baseado em circunstância desvinculada da obtenção da prova, da existência física da prova e das circunstâncias que dizem respeito a sua existência, ou seja, baseado na capacidade econômico-financeira, se a parte com o potencial sob enfoque tem condições concretas,

\footnotetext{
306 Sob outro enfoque, quando o magistrado dinamiza o ônus da prova, com fundamento no requisito da desigualdade econômico-financeira, duas variáveis ocorrem. A primeira implica deixar de aplicar ao jurisdicionado incapaz economicamente analisando os termos da Lei 1.060/50, o que gera uma celeridade processual, pois são raros os profissionais liberais, nomeados peritos, v.g., que aceitam receber seus honorários ao final da demanda, caso a parte com potencial econômico seja derrotada. A segunda implica desoneração do Estado quanto ao pagamento indireto de determinadas despesas advindas de provas periciais, v.g., naquelas hipóteses em que o juiz nomeia um agente do Estado para realizar a perícia - médico da rede pública de saúde -, onerando todo o sistema.
} 
efetivas, de produzir a prova, sob pena ainda de se caracterizar a denominada prova diabólica reversa.

Retomando o exemplo acima citado, configuraria a hipótese de prova diabólica reversa, se a mencionada grande empresa, então demandada, com a aplicação da dinamização do ônus da prova, fosse incumbida do ônus quanto à determinada prova e, consequentemente, de produzir uma prova pericial, arcando com as respectivas despesas. Contudo, essa perícia deveria ser realizada em documentos que estavam na posse da parte autora, a qual, dolosa ou até mesmo culposamente, desapareceu com eles. Depreende-se daí que, mesmo com potencial econômico-financeiro prevalente, a empresa jamais conseguirá produzir tal prova.

Na seara prática, a parte que requer e necessitar da produção de prova que tenha despesas extras em sua execução, v.g., honorários periciais, deverá provocar o magistrado quanto ao fato de não possuir capacidade econômico-financeira para tal. O momento ideal será o do saneamento do processo ou tão logo a referida parte tome conhecimento do valor exato para a produção da respectiva prova.

Não se deve esquecer que o magistrado não irá determinar à parte não onerada, i.e., com plena capacidade econômico-financeira, que produza e consequentemente arque com as despesas da produção dessa prova, pois ele apenas irá, ao cumprir o dever de informação específica, ${ }^{307}$ cientificar as partes que poderá, na sentença, dinamizar o ônus da prova e, assim, na hipótese de permanência de incertezas fáticas, sancionar a parte então onerada.

Diante disso, a comprovação da ausência de capacidade econômico-financeira da parte requerente quanto à produção da referida prova, deverá ser amplamente realizada pela respectiva parte através de documentos e todos os demais meios de prova permitidos em lei, inclusive testemunhal, aproveitando, para isso, a própria fase probatória. ${ }^{308} \mathrm{Em}$ contrapartida, a parte requerida, em absoluto respeito à ampla defesa e ao contraditório poderá, também na própria fase probatória, demonstrar que, na realidade, o autor possui capacidade econômica para produzir a referida prova e/ou que também não a possui, não

\footnotetext{
307 Cf. a seção 3.2.2.2 - Dever de informação e aplicação da dinamização. O dever de informação mencionado no texto é um dos elementos estruturais desta teoria e será analisado com profundidade à frente. ${ }^{308} \mathrm{Cf}$. circunstância e solução semelhante na seção 3.2.2.1.6.3 - Destruição de provas.
} 
devendo, assim, ser aplicada a dinamização do ônus da prova, o que somente será decidido no momento do proferimento da sentença.

Após o cumprimento do dever de informação específica pelo magistrado, as partes poderão realizar a prova ou, usando da faculdade que lhes assiste permanecer inertes. Contudo, se a parte requerida resolver produzir a respectiva prova, deverá arcar com os custos. Caso a parte autora, reveja seu posicionamento, também poderá produzir a prova, pagando os respectivos custos, desistindo, assim, do requerimento de aplicação da dinamização do ônus da prova.

Por fim, deve-se ressaltar que este requisito de aplicabilidade da teoria da dinamização do ônus da prova deve ser utilizado com muita cautela e critério pelo magistrado, pois, se banalizado, ao invés de gerar justiça, irá provocar injustiças.

\subsection{Desigualdade técnica}

A premissa mais importante deste assunto é estabelecer, de forma categórica, que a desigualdade técnica, diferentemente da desigualdade econômico-financeira, diz respeito direta e essencialmente à produção da prova. É essa análise que o magistrado deverá implementar para decidir se aplica ou não a dinamização do ônus da prova diante do caso concreto, com fulcro neste requisito.

Não se pode negar que a desigualdade econômico-financeira em alguns casos concretos pode coexistir com a desigualdade técnica. Não se pode negar ainda que essa desigualdade processual, em âmbito prático-jurídico e na vida do jurisdicionado, também gera reflexos e dificuldades à própria obtenção do direito material.

Recorre-se, novamente, à metodologia exemplificativa para tornar mais claro este requisito de aplicação da dinamização do ônus da prova. Duas empresas de igual porte e semelhantes condições financeiras litigam em decorrência de um produto adquirido por uma delas, sob a alegação que o referido produto não funciona exatamente como acordado nas negociações de venda. Na hipótese, uma empresa automobilística adquiriu de uma 
outra empresa de logística e informática um software destinado a gerenciar parte de sua linha de produção de automóveis. Contudo, segundo a empresa automobilística, o software adquirido apresenta vício que lhe impede de atingir as expectativas almejadas na linha de produção. Em contrapartida, a empresa de informática alega que não existe vício e que o software não é o responsável pelas frustrações em relação às expectativas quanto à produção de automóveis. Neste caso hipotético, não resta dúvida que a empresa automobilística está em desigualdade técnica em relação à empresa de informática, pois todo o conhecimento técnico-científico utilizado na criação do produto, inclusive protegido pela lei de direitos autorais e patentes, está na posse desta última. ${ }^{309}$ Evidente, assim, que o ônus da produção dessa prova deve ser atribuído à empresa de logística e informática, parte requerida nesta abstrata demanda. ${ }^{310}$

Em efeito, todas as vezes que em uma demanda, a parte onerada com a produção da prova, com base no artigo 333 e incisos do CPC, não detiver o domínio do conhecimento técnico-científico especializado, v.g., o conhecimento do respectivo projeto, da respectiva técnica, bem como de quaisquer informações essenciais e privilegiadas sobre o thema probandum, o juiz deverá aplicar a teoria da dinamização do ônus da prova, promovendo assim a igualdade processual relativamente à produção da prova.

Este requisito de aplicabilidade da teoria é mais facilmente identificado em situações fáticas, levadas ao Poder Judiciário, envolvendo fabricantes de toda ordem, fornecedores de bens e produtos, prestadores de serviços de todo gênero, pois, regra geral, são eles detentores de informações privilegiadas sobre o objeto da demanda, normalmente

\footnotetext{
${ }^{309}$ PATTI, Prove..., 1987, p. 174, afirma ser progressiva, sobretudo na experiência do direito alemão, a idéia de repartição do ônus da prova com base em setores ou âmbitos de risco, também em relação à responsabilidade contratual, sendo decisiva a respeito a consideração segundo a qual seria extremamente difícil ou absolutamente impossível para o autor produzir a prova de um evento danoso que teve origem no âmbito do domínio ou no âmbito da organização da parte contrária. (tradução nossa).

${ }^{310}$ Ainda na seara exemplificativa, diante da precisão para o esclarecimento do assunto ora tratado, insta colacionar o descrito por Kazuo Watanabe, ao discorrer sobre o CDC: "numa relação de consumo [...], a situação do fabricante é de evidente vantagem, pois somente ele tem pleno conhecimento do projeto, da técnica e do processo utilizado na fabricação do veículo e, por isso, está em melhores condições de demonstrar a inocorrência do vício de fabricação. A situação do consumidor é de manifesta vulnerabilidade, independentemente de sua situação econômica. O mesmo acontece, [...], nas relações de consumo em que a outra parte tem o domínio do conhecimento técnico especializado, em mutação e aperfeiçoamento constantes, como ocorre no setor de informática.". In GRINOVER, Ada Pellegrini et al. Código brasileiro de defesa do consumidor: comentado pelos autores do anteprojeto. 6. ed. rev. atual. até julho de 1999. Rio de Janeiro: Forense Universitária, 2000. p. 734.
} 
diretamente ligadas à causa de pedir que, por sua vez, diz respeito a algum fato pertinente às respectivas atividades comerciais.

Ainda na seara das informações privilegiadas, de cunho técnico-científico, estão aqueles profissionais que utilizam diretamente tais conhecimentos em suas atividades laborais diárias, v.g., os médicos, advogados, engenheiros etc.

É patente a desigualdade técnica naquelas demandas cujo paciente reivindica direitos oriundos da atividade do médico, derivados de serviços prestados por profissional da área médico-hospitalar. Nesses casos concretos a citada desigualdade chega ao patamar de inviabilizar a própria demanda no tocante à produção da prova. Nesse mesmo sentido, verifica-se a desigualdade técnica naquelas demandas cujo cliente reivindica direitos supostamente lesados pelo profissional liberal no exercício de sua atividade, v.g., advogado contratado para o exercício de uma defesa processual, o arquiteto contratado para a execução de um projeto etc.

Vale ressaltar, o que corrobora a necessidade e eficiência da aplicação da teoria da dinamização do ônus da prova, que em determinadas situações, a parte com menor potencial econômico-financeiro será aquela com maior potencial técnico e, justamente por este motivo, será onerada com o ônus dinâmico da prova. Pode-se formular a hipótese de um arquiteto, um engenheiro hidráulico e um engenheiro elétrico, contratados por uma empresa do ramo imobiliário e de construção civil para criarem, respectivamente, um projeto arquitetônico, um projeto hidráulico e um projeto elétrico visando à construção de um grande e luxuoso shopping center. Evidente que estes profissionais liberais, mesmo eventualmente figurando no polo contrário da demanda uma pessoa jurídica com potencial econômico-financeiro muitas vezes superior aos seus, detém informações privilegiadas, sob o aspecto técnico, a respeito desses projetos.

Em síntese, diante da flagrante e inquestionável facilidade na produção da prova, ${ }^{311}$ uma vez que tais partes são as detentoras desse conhecimento técnico-científico

\footnotetext{
311 Substancialmente nesse sentido ARENHART, Ônus da prova..., 2009, p. 349. Sustenta o autor que, segundo esta visão da "hipossuficiência", sua função seria permitir a distribuição dinâmica do ônus da prova, imputando-o a quem tem maior facilidade na produção da prova. Se esta parte - que tem acesso privilegiado à
} 
especializado, lato e stricto sensu, bem como de informações privilegiadas sobre o thema probandum, é razoável, proporcional, justo, constitucional e equânime, que o juiz dinamize o ônus da prova, imputando a essas, além do dever que lhes é peculiar diante do princípio da cooperatividade, o ônus da prova e via de consequência, o risco de sua omissão ou insuficiência na produção da prova.

\subsection{Prova complexa ${ }^{312}$}

A necessidade, no caso concreto, de produção de prova complexa consiste em outro requisito a ensejar a aplicação da teoria da dinamização do ônus da prova. ${ }^{313}$ Entretanto, o tema da prova complexa possui múltiplas dificuldades, e, de várias ordens, dentre elas está a de conceituação e delimitação de seus respectivos contornos teóricos.

Costuma-se confundir as expressões e os significados de "prova complexa", "prova difícil", "processo ou demanda ou causa complexa" e "sentença complexa". Certo que todos esses temas guardam íntima ligação e se correlacionam diante da experiência processual, porém não são idênticos.

Ademais, a complexidade ou dificuldade pode estar situada tanto na zona de obtenção, quanto na zona de produção da prova. Quanto a essa diferenciação se pode afirmar que, regra geral, toda vez que houver complexidade na obtenção da prova, haverá em sua produção, o que não se equivale na hipótese inversa. E é exatamente esse um dos fatores pelo qual o presente tema ganha destaque na doutrina pátria somente sob o aspecto processual. Em efeito, doravante, quando for mencionado o termo complexidade da prova estar-se-á referindo à dificuldade na produção da prova.

prova do fato (de sua existência ou não) - não elimina a dúvida judicial a respeito do tema, é justo que se lhe impute o prejuízo decorrente da "não-prova". (grifos do autor).

${ }^{312}$ Cf. Título IV, seção 4.2 deste trabalho, onde é abordado projeto de lei que estabelece a prova complexa como requisito de aplicação da dinamização do ônus da prova.

${ }^{313}$ Nesse sentido MORELLO, Dificultades de la prueba..., 2004, p. 48. Afirma que em processos de alta complexidade, impõem-se sua adequação e o re-equilíbrio de ônus, deveres e poderes específicos, de acordo com a natureza ou essência desses conflitos [...] e das peculiaridades do objeto a elucidar. (tradução nossa). 
Importante ainda não perder de vista as afirmativas do parágrafo anterior uma vez que haverá situações em que a aplicação da teoria da dinamização do ônus da prova será devida pela complexidade existente tanto na obtenção quanto na produção da prova.

Não obstante, necessário estabelecer a premissa de que o requisito que enseja a aplicação da teoria sob enfoque consiste na complexidade na produção da prova.

Vale ressaltar ainda que o magistrado, ao se deparar com a necessidade de produção de provas complexas nos autos, deve averiguar se há efetiva facilidade e possibilidade de uma das partes em sua produção, sob pena de transformar a prova complexa para uma parte em prova diabólica para a outra, tema este que será aprofundado adiante, caso aplique inadvertidamente a teoria da dinamização do ônus da prova.

Neste tópico não se objetiva, precipuamente, estabelecer de forma exaustiva todas as hipóteses de prova complexa e sim estabelecer os contornos do tema como requisito de aplicação da teoria da dinamização do ônus da prova.

Em âmbitos conceituais, pode-se definir a prova complexa como sendo aquela prova de difícil produção. Até então, estamos na seara da tautologia, ou seja, dissemos a mesma coisa com palavras distintas.

Necessário, assim, definir em que consiste essa dificuldade que caracteriza a denominada prova complexa, também conhecida por prova difícil, termo menos técnico.

Ad abundantiam, necessário fixar que não é possível estabelecer numerus clausulus as hipóteses que configuram prova complexa. Isso ocorre em virtude de diversos fatores, sendo os principais deles a indeterminabilidade quantitativa dessas hipóteses e os avanços da ciência e da técnica, ${ }^{314}$ pois, o que no passado era considerado como prova complexa, no futuro pode não ser diante desses avanços. Evidência dessa mobilidade conceitual era a dificuldade na produção da prova pertinente à filiação que se dava de forma majoritária por

\footnotetext{
${ }^{314}$ Cf. PEYRANO, Jorge W. La prueba difícil. In ARAZI, Roland et al. Debido proceso: realidad y debido proceso: el debido proceso y la prueba. Santa Fé: Rubinzal-Culzoni, 2003. p. 333.
} 
testemunhos e confissões, meios de prova atualmente secundários para esses fins, diante da produção de provas científicas consistentes no exame hematológico e de DNA.

A complexidade da prova, como acima mencionado, pode ocorrer por diversos fatores. Esses fatores, todavia, não guardam a característica da universalidade, pois em determinadas situações o mesmo fator pode configurar prova complexa, mas em outras não. Daí seu caráter contingente.

Alguns dos fatores guardam íntima ligação com a natureza da demanda, que por sua vez e regra geral, também consistirá em uma demanda complexa. Outros se referem exclusivamente à produção da prova em juízo.

Estabelecidas essas características, insta afirmar que os quatro principais elementos que geram complexidade na produção da prova consistem em: a) quantidade de participantes na demanda; b) extensão dos efeitos da decisão judicial na sociedade; c) necessidade de intervenção de terceiros na demanda para produção de prova científica e especializada e, d) burocracia procedimental.

$\mathrm{O}$ primeiro fator mencionado diz respeito à quantidade de participantes na demanda. O elevado ou indeterminado número de legitimados ativos e passivos, principalmente diante de um litisconsórcio necessário, regra geral e com base empírica, gera dificuldades na produção da prova. Isso fica límpido ao se tomar como exemplo um evento que casou dano para um grande ou indeterminado número de pessoas, quer seja em um mesmo momento fático ou em lapsos temporais diferentes. ${ }^{315}$

O segundo refere-se à extensão dos efeitos, de ordem jurídica, social e política, que o julgado pode gerar na sociedade. É o caso das provas a ser produzidas em demandas que tenham por objeto questões relacionadas ao meio ambiente, a padrões de urbanismo, paisagismo, ao direito agrário, a lesões a direitos fundamentais do cidadão etc. Inclui-se aqui, diante desses efeitos, as provas a ser produzidas nas demandas de improbidade

\footnotetext{
${ }^{315}$ O próprio CPC, em seu artigo 46, parágrafo único, ao permitir que o juiz limite o litisconsórcio facultativo quando houver um número excessivo de litigantes, reconhece a complexidade da demanda e, consequentemente, a complexidade na produção de provas nesta hipótese. Cf. ainda o teor da nota 286, seção 3.2.1.4 - Dinamização versus inversão do ônus da prova, onde consta julgado nesse sentido.
} 
administrativa. Sustenta-se, v.g., que o magistrado deve aplicar a teoria da dinamização do ônus da prova quando houver sinais externos de enriquecimento ilícito por parte de agentes públicos, imputando-lhes o ônus da provar que seu patrimônio foi constituído com lastro financeiro de origem lícita.

O terceiro elemento é o mais comum na prática forense. Relaciona-se com a complexidade advinda da efetiva necessidade de intervenção de um terceiro, na função de auxiliar da justiça. Isso poderá ocorrer por dois motivos: a) quando somente um expert puder produzir a prova, pois necessário o conhecimento específico de outros ramos do conhecimento científico ou técnico ou, b) quando somente um expert for capaz de interpretar, cientificamente, a prova produzida pelas partes, v.g., afirmar com base nos dados constantes de determinado livro contábil de uma empresa, se foram desviados recursos. $^{316}$

Quanto a esse fator, é assente na doutrina e jurisprudência, interpretando a norma do artigo 35 caput e parágrafo único da Lei 9.099/95, que prova complexa é aquela que necessita de intervenção de um agente externo com conhecimentos especializados sobre determinado fato ou ciência, ou seja, é aquela que deve ser produzida por um perito - prova pericial. $^{317}$

O último elemento que caracteriza a complexidade na produção da prova diz respeito ao que denominamos de burocracia procedimental na esfera da produção e da obtenção da prova. Especificamente, trata-se daquelas hipóteses em que uma das partes tem efetivas dificuldades de acesso a documentos sob a custódia de órgãos públicos, o que torna, com frequência, a prova impossível de ser produzidas por essa. Nesta hipótese, o

\footnotetext{
316 Importantes as afirmativas de MORELLO, Dificultades de la prueba..., 2004, p. 38 e 41, que correspondem à realidade forense em nosso país, nesse particular: "A prova [...] pericial e científica, levam um peso demasiadamente definidor à demanda, em relação às provas historicamente mais importantes, v.g., testemunhal e da confissão, que passam a ter valor residual ou complementar diante daquelas. [...] A declaração do perito tem uma influência determinante e sua aceitação ou rejeição geralmente definirá o resultado do litígio.”. (tradução nossa).

317 Nesse sentido o Enunciado 12 ratificado pelo XXVII Fórum Nacional de Juizados Especiais FONAJE/2010, no qual restou consignado que a perícia informal é admissível na hipótese do artigo 35 da Lei 9.099/1995. Ainda quanto à prova complexa no âmbito juizado foi ratificado também o Enunciado 54, que informa que a menor complexidade da causa para a fixação da competência dos Juizados Especiais Cíveis é aferida pelo objeto da prova e não em face do direito material.
} 
magistrado deverá averiguar ainda se a respectiva parte tem realmente dificuldade na produção dessa prova.

Pode ocorrer, assim, que a burocracia procedimental subsista no bojo do processo, por obra de uma das partes da relação processual que, na realidade, em decorrência de normas de cunho material, tem a obrigação de produzi-la. Insta mencionar o exemplo de um demanda originária da suspensão do ato de aposentação de um funcionário público estadual, por parte do Instituto de Previdência Social Estadual, sob a alegação de que o tempo de contribuição fora incorretamente averbado. É infinitamente mais fácil para o Instituto, parte requerida nesta hipotética demanda, apresentar a prova de seu próprio equívoco. Esta prova, na realidade, deveria ter sido expedida em forma de certidão, e entregue pelo Instituto ao aposentado, na fase administrativa, por ser direito constitucional de todo cidadão. Na esfera processual, a sua insistência em não produzir tal prova configura, dentre outras coisas, verdadeira burocracia procedimental, ensejando a aplicação da dinamizado do ônus da prova.

Por fim, recorrendo mais uma vez ao método da exemplificação, evidenciam-se hipóteses que configuram prova complexa ${ }^{318}$ a ensejar, sempre diante da análise do caso concreto, a aplicação da dinamização do ônus da prova: a) produção de provas que se refiram à tutela da privacidade do indivíduo; b) produção de prova relativa a transações e operações financeiras em bolsas de valores e mercadorias futuras, envolvendo ações, opções etc.; c) produção de prova pertinente a fatos que envolvam sistema societário, financeiro, fiscal, contratos bancários, contratos de câmbio, contratos de seguros; d) contratos administrativos envolvendo obras públicas, concessões, permissões, licenças, instituição de tarifas; e) produção de prova relativa à bioética.

\footnotetext{
${ }^{318}$ PEYRANO, La prueba difícil, 2003, p. 329-332, estabelece as hipóteses que configuram prova complexa: a) fatos antigos; b) os fatos e circunstâncias ocorridas em uma atmosfera de particular privacidade; c) afirma que a doutrina espanhola cita a prova de lucros cessantes como prova difícil; d) prova impossível, sendo aquela que, por diversas razões, não poderá ser produzida por quem suporta o ônus em questão; e) prova extinta, sendo aquela cujo suporte material desapareceu. MORELLO, Dificultades de la prueba..., 2004, p. 34, ainda nesta seara da prova complexa, sustenta que as concentrações monopolísticas ou oligopolísticas de capital em empresas de produção, comercialização, distribuição em distintos tipos de novos negócios, a dilatação de contratos internacionais, as combinações para alcançar consumidores de países ou regiões ou comunidades, põem à prova diversos sistemas jurídicos nacionais que se veem engessados em sua operacionalidade pelo rol prioritário dos princípios transnacionais comunitários.
} 


\subsection{Prova diabólica}

A probatio diabolica é considerada um dos requisitos de aplicabilidade da teoria da dinamização do ônus da prova a partir do momento que não se caracterize, por via reflexa, a prova diabólica reversa, que por sua vez, consiste em um dos limites à aplicação da dinamização, objeto de análises adiante. ${ }^{319}$

Em efeito, o magistrado ao averiguar que a produção da prova de determinado fato pode ser considerada diabólica para o autor, deverá paralelamente averiguar se, ao aplicar a dinamização do ônus da prova em relação a tal fato, imputando-a ao requerido, não criará para este uma prova diabólica reversa. Se isso se configurar no caso concreto, não há falarse em aplicação da teoria sob enfoque.

Contudo, quando não se configurar a prova diabólica reversa, deverá o magistrado, diante dessa total impossibilidade de uma das partes em produzir determinada prova, aplicar a dinamização do ônus da prova, imputando à outra parte o respectivo ônus. Assim, após o cumprimento do dever de informação pelo juiz, a parte que possui efetiva possibilidade e facilidade quanto à produção daquela prova, deverá fazê-lo, sob pena de sofrer as consequências de sua inércia.

Necessário, diante do tema, conceituar prova diabólica e identificar suas hipóteses concretas. Pode-se afirmar que se configurará prova diabólica todas as vezes que a parte não tiver condições materiais de produzi-la em juízo, por circunstâncias fáticas absolutamente impeditivas.

Extremamente relevante registrar que prova diabólica não se confunde com a denominada prova difícil, não sendo, portanto, expressões sinônimas. A prova difícil é aquela que apresenta um ou mais obstáculos para que determinada parte consiga produzi-la nos autos. Contudo, esses obstáculos são fática e juridicamente transponíveis, tornando-a, apesar de difícil, possível de ser produzida. Diversamente desta, a prova diabólica transcende o grau da dificuldade, chegando ao nível da impossibilidade. A prova diabólica

${ }^{319}$ Cf. seção 3.2.2.4.1. 
é aquela que apresenta um ou mais obstáculos intransponíveis pela parte que tem interesse em produzi-la ou está onerada com sua produção. ${ }^{320}$

Utilizando o método exemplificativo, necessário supor que a parte onerada tenha interesse em produzir em juízo uma prova documental essencial a sua alegação. Essa prova será considerada difícil quando esse documento se encontrar, simplesmente, na posse da outra parte, a qual a parte onerada não tenha acesso. Por outro lado, essa prova guardará a característica de diabólica quando esse documento se encontrar sob custódia, em um cofre, de um banco no exterior. Na primeira hipótese existe um obstáculo difícil, mas transponível. Na segunda hipótese o obstáculo é, para a parte inicialmente onerada, intransponível.

Vale ressaltar que a jurisprudência pátria é rica em exemplos de prova diabólica e sua consequente dinamização do ônus da prova, ainda que esta denominação não seja usada, comprovando sua natureza contingente, implicando, como já evidenciado, na necessidade de análise das circunstâncias fáticas que envolvem cada caso concreto. ${ }^{321}$

\footnotetext{
${ }^{320}$ Neste âmbito, recente julgado considerou a produção de prova de um fato negativo como prova dificílima e, em efeito, caracterizadora de prova diabólica. Segue transcrição ipsis litteris da ementa e parte do acórdão: Agravo Regimental. Recurso Especial. Agravo de Instrumento. Peça Obrigatória. Certidão de Intimação da Decisão Agravada. Formalismo Excessivo. Prova Diabólica. Meio Diverso de Verificação da Tempestividade. Notificação Extrajudicial. Possibilidade. 2. Exigir dos agravados a prova de fato negativo (a inexistência de intimação da decisão recorrida) equivale a prescrever a produção de prova diabólica, de dificílima produção. Diante da afirmação de que os agravados somente foram intimados acerca da decisão originalmente recorrida com o recebimento da notificação extrajudicial, caberia aos agravantes a demonstração do contrário. STJ. $3^{\text {a }}$ Turma. AgRg no AgRg no REsp 1187970/SC. Rel. Ministra Nancy Andrighi. Data do Julgamento 05/08/2010. Data da Publicação DJe 16/08/2010. Vale ressaltar que o presente julgado, sem adentrar no mérito do efetivo grau de dificuldade da prova mencionada, considerou que uma prova dificílima pode ser enquadrada e conceituada como prova diabólica.

${ }^{321}$ Insta colacionar exemplo de prova diabólica ante sua total impossibilidade de produção. Segue transcrição ipsis litteris da ementa e parte do acórdão: Direito Administrativo. Recurso Especial. Servidor Público. Anistia. Demissão Por Motivação Política. Prova Direta ou Material Impossível. Ato Demissório Dissimulado. Contexto Demonstrativo da Nota Política da Demissão do Recorrente. Prova em Contrário que Compete à Administração. Inaplicabilidade da Súmula 7/STJ. Valoração da Prova. Recurso Conhecido e Provido. 1. A prova, nos casos de concessão de anistia para fins de reintegração ao serviço público, é sempre indireta e deve decorrer da interpretação do contexto e das circunstâncias do ato apontado como de motivação política. 2. A prova direta, material ou imediata é rigorosamente impossível em caso dessa espécie. Impor ao autor que a faça significa, em verdade, impor-lhe a chamada prova diabólica, de produção impossível, porque os afastamentos dos cargos, à época, eram disfarçados; assim, por exemplo, quando militar o servidor, afastava-se por indisciplina ou insubordinação; quando civil, por ato de abandono e outras alegações com a mesma finalidade e do mesmo teor. Destarte, compete à Instituição que promoveu o ato demissionário demonstrar a inexistência de motivação política. STJ. 5 ${ }^{\text {a }}$ Turma. REsp 823122/DF (2006/0042247-7). Rel. Min. Arnaldo Esteves Lima. Relator p/ Acórdão Min. Napoleão Nunes Maia Filho. Data do Julgamento 14/11/2007. Data da Publicação/Fonte DJe 18/02/2008.
} 
Quanto à preclusão temporal não se pode negar que a mesma consiste em um obstáculo processual intransponível para que a parte produza determinada prova. Entretanto, não se considera essa circunstância jurídica como caracterizadora de prova diabólica, pois a parte teve todas as condições materiais e jurídico-formais de produzi-la, mas deixou escoar o prazo para tal. Assim, inicialmente, não havia qualquer obstáculo para que a parte produzisse a prova desejada, tendo sido ela própria quem deu causa ao obstáculo. Não é essa a essência conceitual da doutrina da prova diabólica.

Conclui-se, assim, ser correto afirmar que todas as circunstâncias jurídicas que configuram um obstáculo à produção da prova são transponíveis, pois deve prevalecer em âmbito do direito processual civil, o direito constitucional à prova, o que implica sua ampla produção.

Firmadas essas premissas, necessário identificar, ainda que de forma geral e parcial, pois as hipóteses concretas são infinitas, as mencionadas condições materiais que impedem, em absoluto, a produção da prova, configurando assim prova diabólica. Essas condições são, na essência, circunstâncias fáticas que tornam impossível a produção (jurídica) da prova.

As condições materiais caracterizadoras da prova diabólica, que implicam absoluta impossibilidade de produção da prova caracterizam-se quando: a) a prova não mais existir fisicamente; b) a prova estiver em local desconhecido de ambas as partes; c) a parte onerada não tiver tido qualquer tipo de participação fática quando do acontecimento da vida que originou a fonte de prova, ou seja, houve de sua parte uma absoluta ausência física no fato, no evento, no acontecimento da vida que originou a causa de pedir da demanda ajuizada; d) quando a parte não onerada, diante de condições privilegiadas de poder e/ou autoridade em relação à outra parte, dissimilou as circunstâncias fáticas e/ou as próprias provas diretas.

Outro elemento que gira em torno da caracterização da probatio diabolica é o relativo à prova de fato negativo. Esta consiste, indubitavelmente, em uma prova difícil de ser produzida, porém não impossível, instransponível, na maioria dos casos. A doutrina pátria há muito tempo deixou de considerá-la, genericamente, como prova diabólica. 
Todavia, as circunstâncias de cada caso concreto podem caracterizar a prova de um fato negativo como prova diabólica, o que será detalhado em seguida. ${ }^{322}$

\subsection{Prova de fato negativo}

A prova dos fatos negativos sempre integrou o rol dos temas polêmicos, sendo objeto de muitas discussões na doutrina e jurisprudência. Weber, Wach, Rosenberg, v.g., consideraram o brocardo latino affirmanti non neganti incumbit probatio, que acabou por se transfigurar no princípio negativa non sunt probanda, como um erro jurídico absolutamente superado. ${ }^{323}$

Em âmbito doutrinário, na atualidade, não existe mais celeuma quanto à possibilidade de se produzir prova de um fato negativo. Todavia, o tema ganha maior repercussão na seara prática, diante da dicotomia fato negativo relativo e fato negativo absoluto.

Inegável que existe uma presumível dificuldade quanto à produção da prova de um fato negativo. A prova de um fato negativo, na essência, é a prova de um não-fato. Um não-fato não se prova diretamente, mas por dedução. Assim, a comprovação de um nãofato deduz-se da percepção de algo que não se poderia perceber caso o fato existisse, ou ainda, daquilo que não se percebe, mas se deveria perceber, se o fato existisse. ${ }^{324}$ Outra forma indireta de se provar o fato negativo é desconstituir as circunstâncias favoráveis à

\footnotetext{
${ }^{322}$ Cf. julgado citado na nota 320 .

323 In ROSENBERG, La carga.., 2002, p. 377. Ainda, PATTI, Prove..., 1987, p. 53; CHIOVENDA, Instituições..., 1965, v. 2, p. 377. Este jurista afirma que, via de regra, toda afirmação é, ao mesmo tempo, uma negação, pois quando se atribui a uma coisa um predicado, negam-se todos os predicados contrários ou diversos dessa coisa.

${ }^{324}$ Cf. CARNELUTTI, La prueba..., 2000, p. 56-67, quanto à dedução e percepção como meio de prova. PATTI, Ibid., p. 54, ao revés, sustenta que na realidade se fala erroneamente de prova do fato negativo, pois a prova pode ser obtida mediante a prova de uma afirmação positiva contrária, uma vez que, regra geral, todo fato negativo comporta uma antítese imediata sob a forma de uma proposição positiva contrária. (tradução nossa).
} 
existência de um fato positivo. ${ }^{325}$ Vale ressaltar que também determinados fatos positivos somente podem ser provados pela via indireta, não sendo exclusividade daqueles. ${ }^{326}$

A nossa jurisprudência também já superou a antiga e complexa construção acerca da prova dos fatos negativos, considerando equivocado o entendimento de que o fato negativo nunca se prova. Firma-se o entendimento de que quando um fato negativo contém em seu bojo um fato positivo, este deve ser provado. Em efeito, toda vez que for possível a produção de prova de um fato positivo contrário àquele negativo deduzido pela parte contrária, estará superada a já ultrapassada teoria da prova negativa, bem como sua versão atualizada sob as vestes da prova impossível. ${ }^{327}$

A vexata quaestio nesse particular situa-se na dificuldade de distinguir, no caso concreto, se o fato negativo alegado se enquadra no denominado fato negativo absoluto ou indefinido ou indeterminado, que é insuscetível de prova. ${ }^{328}$ A doutrina apresenta como exemplo clássico de fato negativo absoluto a necessidade de se provar que determinada pessoa nunca esteve em determinado local. ${ }^{329}$ Entretanto, esse fato negativo pacificamente reconhecido como absoluto, pode ser relativizado, $v . g$., se a referida pessoa encontra-se em um leito de hospital por longos anos.

Em âmbito de distribuição do ônus da prova em hipótese de fato negativo, os nossos Tribunais Superiores e Estaduais vem aplicando a "inversão" do ônus da prova, imputando tal ônus, regra geral, àquela parte que tem maior facilidade de provar o fato

\footnotetext{
${ }^{325}$ Nesse sentido ROSENBERG, La carga..., 2002, p. 377-378.

${ }^{326}$ CARNELUTTI, La prueba..., 2000, p. 59, sustenta que não se deve distinguir com tanta ênfase a prova direta da indireta, pois ambas são processos de fixação do fato controvertido por obra do juiz. A diferença entre ambas não é de função, sendo somente de estrutura.

${ }^{327}$ Nesse sentido STJ. 5 5 Turma. AgRg no Ag 1181737/MG (2009/0024110-6). Rel. Min. Arnaldo Esteves Lima. Julgado em 03/11/2009. Publicado em 30/11/2009; STJ. $3^{\text {a }}$ Turma. REsp 1050554/RJ (2008/00860043). Rel. Min. Nancy Andrighi. Julgado em 25/08/2009. Publicado em 09/09/2009. Neste, a Min. Relatora afirma que a máxima de que as negativas são isentas de prova não é verdadeira, porquanto dizem respeito tão-somente as negativas indefinidas, ou seja, não abarcam as negativas relativas, suscetíveis de prova.

${ }^{328}$ Nesse sentido CHIOVENDA, Instituições..., 1965, v. 2, p. 377-379; SANTOS, Prova Judiciária..., 1970, v. 1, p. 150; LOPES, A prova..., 2002, p. 34. PATTI, Prove..., 1987, p. 54, afirma que fato negativo indefinido é aquele que não comporta uma antítese imediata sob a forma de uma proposição positiva contrária. Cita como exemplo de fato negativo indefinido a prova da ausência de culpa. (tradução nossa).

${ }^{329}$ Em contrapartida, o exemplo clássico de fato negativo relativo consiste na prova da afirmativa que Caio não estava em São Paulo, no dia 31.12.2009, às 22h. Ainda, o condômino que requer a declaração da invalidade de uma deliberação da assembléia condominial deve fornecer a prova (negativa) que as regras sobre a formação da vontade da assembléia não foram respeitadas.
} 
positivo colidente com o fato negativo. ${ }^{330}$ Não obstante, não é incomum manter-se a regra geral de quem alega um fato, mesmo que seja negativo, tem o ônus de prová-lo.

Importante ressaltar que a "inversão" aplicada nas hipóteses de fato negativo relativo, na essência e indubitavelmente, é mais um caso de dinamização do ônus da prova. $\mathrm{Na}$ realidade, não existe na nossa legislação qualquer norma específica que permita o julgador excepcionar a regra de distribuição geral do ônus da prova nessas hipóteses de fato negativo. ${ }^{331}$ Todavia, naquelas hipóteses em que a demanda versa sobre direito do consumidor, por obra de interpretação extensiva, o julgador tem aplicado a regra do artigo $6^{\circ}$, inciso VIII do CDC também para fatos negativos, não sendo esse o caminho adequado diante da mencionada situação específica.

Alguns julgados, a título de justificativa para dinamizar o ônus da prova do fato negativo, imputando-o ao requerido, falam em "inversão" do ônus da prova pela ordem natural do processo; ${ }^{332}$ pela inexistência de dificuldade para o demandado fazer prova da entrega dos documentos ao demandante, porque bastará para tanto a apresentação de recibo passado pelo requerente, ${ }^{333}$ pela facilidade do requerido em provar a existência ou inexistência de solicitação prévia de serviço de telefonia ${ }^{334}$ etc.

Insta abrir parêntese, antes de concluir esta seção, para ressaltar a importância do fato negativo na teoria da dinamização do ônus da prova, uma vez que em relação a esse, já se reconhecia como justificável e, assim foi aplicado sem contestações, a modificação pelas mãos dos juízes da regra geral de distribuição do ônus da prova, diante do fator absolutamente explícito da maior facilidade da produção prova de um fato positivo. ${ }^{335}$

\footnotetext{
${ }^{330}$ Cf. julgados mencionados na nota 320 .

331 A afirmativa vale integralmente para o direito processual civil italiano. PATTI, Prove..., 1987, p. 53, nota 3, citando a jurisprudência daquele país, afirma que a prova dos fatos negativos deve ser fornecida mediante aquela dos fatos positivos contrários, pois o fato negativo não exclui nem inverte o ônus da prova. (tradução nossa).

${ }^{332}$ TJSP. 12 ${ }^{\text {a }}$ Câmara de Direito Privado. Agravo de Instrumento 991070628298 (7183160600). Rel. Des. José Reynaldo. Julgado em 12/12/2007. Publicado em 28/01/2008.

${ }^{333}$ TJSP. 34 $4^{\text {a }}$ Câmara de Direito Privado. Apelação 990101382962 Rel. Des. Nestor Duarte. Julgado em 19/07/2010. Publicado em 28/07/2010.

334 TJSP. $34^{a}$ Câmara de Direito Privado. Apelação 992050295607 (1007126000) Rel. Des. Nestor Duarte. Julgado em 24/08/2009. Publicado em 17/09/2009; TJSP. $3^{\text {a }}$ Câmara de Direito Privado. Apelação Com Revisão 994070155874 (5318014800). Rel. Des. Cláudio Lima Bueno de Camargo. Julgado em 27/06/2008. Publicado em 17/07/2008.

335 CHIOVENDA, Instituições..., 1965, v. 2, p. 379, discorrendo sobre o fato negativo afirmou que frequentemente, no caso concreto, sente-se a oportunidade de atribuir o ônus da prova a uma das partes,
} 
Em conclusão, pode-se afirmar que o fato negativo absoluto ou indeterminado pode ser considerado prova diabólica e, assim, requisito hábil a permitir a aplicação da teoria da dinamização do ônus da prova, desde que não se evidencie uma prova diabólica reversa.

Quanto ao fato negativo relativo, este configurará requisito hábil a permitir a aplicação da teoria da dinamização do ônus da prova, desde que se evidencie, no caso concreto, que a parte ex adversa possui maior facilidade na produção da prova, que sempre consistirá em um fato positivo contrário.

\subsection{Ação declaratória negativa}

A distribuição do ônus da prova na ação declaratória negativa apresenta conexão direta com a produção da prova de fato negativo e, ainda, com a prova diabólica e, em efeito, com a teoria da dinamização do ônus da prova.

Tanto na doutrina pátria quanto na estrangeira a distribuição do ônus da prova nas ações declaratórias negativas está longe de ser um tema pacífico, ante sua efetiva complexidade teórica e prática. ${ }^{336}$ Todavia, pode-se afirmar que na maior parte dos ordenamentos jurídicos, assentou-se o entendimento no sentido de aplicar a distribuição tradicional do ônus da prova, imputando à parte autora o ônus da prova. ${ }^{337}$

Em nosso país, uma das posições divergentes sustenta que a distribuição do ônus da prova não pode ter como referência a posição processual de autor ou de requerido, mas sim a natureza do fato jurídico colocado pela parte como base de sua alegação.

enquanto seria difícil formular uma razão geral para fazê-lo. Não é possível dizer a priori que a repartição da prova seja rigorosamente lógica e justa, é, antes de tudo uma razão de oportunidade que compele a repartir o ônus da prova, devendo-se atentar para um princípio de justiça distributiva, i.e., o princípio da igualdade. PATTI, Prove..., 1987, p. 54, afirma que a desvantagem nos confrontos da prova do fato negativo corresponde o princípio da "melhor aptidão à prova" que serve a justificar muitas das soluções elaboradas pela jurisprudência nesta matéria.

${ }^{336}$ Por todos, VERDE, L'onere della prova..., 1974, p. 523, nota 856 e 525.

${ }^{337}$ Nesse sentido CHIOVENDA, op. cit., v. 1, p. 224 (nota 83); PATTI, op. cit., p. 56 (nota 16); PISANI, Andrea Proto. Appunti sulla giustizia civile. Bari: Cacucci Editore, 1982. p. 105; MICHELLI, La carga..., 2004, p. 406; VERDE, Ibid., p. 525. 
Minoritariamente, sustenta-se ser do requerido o ônus da prova nas ações declaratórias negativas. $^{338}$

Em efeito, quando o autor requer ao juiz a tutela jurisdicional declaratória quanto à inexistência de um direito no qual o requerido extrajudicialmente se diz titular, tem o autor o ônus de provar ou a inexistência dos fatos constitutivos do direito ostentado pelo requerido, ou, ainda, a existência de fatos modificativos, impeditivos ou extintivos do mencionado direito do requerido.

Não é difícil perceber que o problema diz respeito à prova do fato negativo, ou seja, da inexistência dos fatos constitutivos do direito ostentado extrajudicialmente pelo requerido. Na essência, a vexata quaestio vai além e situa-se na excessiva dificuldade probatória do autor, advinda da própria natureza negativa dos fatos a ser provados e de sua extensão, uma vez que, a rigor, teria o ônus de provar a inexistência de todos os possíveis fatos constitutivos alternativamente concorrentes do direito alegado pelo requerido e, ainda, nos efeitos da coisa julgada, uma vez que o requerido, em tese, pode obter uma sentença declaratória de seu próprio direito sem que tenha sido provado qualquer fato constitutivo do respectivo direito. ${ }^{339}$

Na busca de uma solução, merecem destaque duas formulações implementadas pela doutrina italiana. Desde já insta pontuar que ambas visaram, na realidade, delimitar o objeto da prova do autor, uma vez que a forma tradicional de distribuição do ônus da prova na ação declaratória negativa, na grande maioria dos casos, visivelmente, constituía para a parte autora uma verdadeira prova diabólica. ${ }^{340}$

A primeira formulação teórica sustentou que caberia ao autor produzir, apenas, a prova dos fatos dos quais derivassem o seu efetivo prejuízo, enquanto ao requerido caberia o ônus de provar que havido agido no exercício de um direito e, via de consequência, que tais fatos tornaram legítima a produção do citado prejuízo. ${ }^{341}$ A segunda formulação

\footnotetext{
${ }^{338}$ Nesse sentido Kazuo Watanabe. In NERY JUNIOR; NERY, Código de processo civil..., 2010, p. 636, nota 6 .

${ }^{339}$ Nesse sentido PATTI, Prove..., 1987, p. 57; PISANI, Appunti..., 1982, p. 106.

${ }^{340}$ Nesse sentido PISANI, Ibid., p. 109.

${ }^{341}$ Originalmente, VERDE, L`onere della prova..., 1974, p. 528 e ss. PATTI, op. cit., p. 57-58 (nota 16), e, PISANI, Ibid., p. 106-107, teceram duras críticas a respeito dessa formulação.
} 
teórica sustentou que caberia ao autor o ônus da prova da inexistência de determinado fato constitutivo do direito ostentado extrajudicialmente pelo requerido o qual seria delimitado tanto pelo petitum quanto pela causa petendi apresentados na demanda. Caso o requerido, após a prova da parte autora, alegasse outros fatos constitutivos de seu suposto direito, não contidos no pedido e na causa de pedir, caberia a ele a produção dessa prova. ${ }^{342}$

De qualquer sorte, não é objeto desta pesquisa, apresentar conclusões a respeito do critério ideal para a distribuição do ônus da prova nas ações declaratórias negativas. Entretanto, o critério aceito majoritariamente em doutrina e jurisprudência, de que cabe ao autor o ônus dessa prova, i.e., o ônus de provar um fato negativo, remonta às conclusões apresentadas nos dois últimos parágrafos da seção anterior, sendo também aplicável na presente hipótese.

Desta forma, diante de uma ação declaratória negativa, é aplicável a teoria da dinamização do ônus da prova, quando o autor necessitar produzir prova quanto à existência de fatos modificativos, impeditivos ou extintivos do direito que o requerido se diz titular (até porque positivos), para demonstrar a inexistência da respectiva relação jurídica.

Quanto ao ônus de provar a inexistência dos fatos constitutivos do direito ostentado pelo requerido, o juiz deverá averiguar, com maior cautela e precisão, por se tratar de fatos negativos, se não estará criando uma prova diabólica reversa, na hipótese de aplicação da teoria da dinamização o ônus da prova.

Assim, v.g., em uma ação declaratória negativa visando uma tutela jurisdicional pertinente à inexistência de uma relação contratual é flagrantemente mais fácil para o requerido provar o fato positivo, i.e., a existência dessa relação, uma vez que aí reside seu interesse processual, não lhe sendo devido descumprir com seu dever de colaboração e, em efeito, usar a estratégia processual da regra tradicional do ônus da prova, aguardando inerte uma sentença baseada em regra de juízo.

\footnotetext{
342 Originalmente, PISANI, Appunti..., 1982, p. 107-111. Para PATTI, Prove..., 1987, p. 58-59, essa
} formulação também não resultou convincente. 


\subsection{Destruição de provas}

A prova pode se tornar diabólica para uma parte, sendo impossível sua produção em juízo, quando a outra parte a destruir, i.e., diante de sua inexistência física.

Quando a prova se tornar diabólica por intervenção de uma das partes, por ato culposo ou doloso, deve incidir nessas hipóteses os efeitos da probatio diabólica em favor da parte ex-adversa, aplicando-se a teoria da dinamização do ônus da prova em desfavor daquele que promoveu a destruição, pois ao agir dessa maneira, violou os deveres de lealdade, probidade e de colaboração processual.

Se a parte requerida detentora de uma prova que lhe é desfavorável, dolosamente a destruir, restaria muito difícil restabelecer o conteúdo da prova em sua total extensão e exatidão. Assim, como a referida parte, que poderia optar por cooperar com o descobrimento da verdade, preferiu optar por destruir definitivamente a prova, deverá sob ela pesar o ônus da prova, arcando com as consequências da incerteza. Este entendimento permite ainda que a mesma parte, caso se arrependa posteriormente de sua opção, prove sua tese defensiva, mediante a produção de outras provas.

A mesma solução deve ser dada quando a prova for destruída por ato culposo, não sendo devido manter o ônus da prova àquela parte que não contribuiu, de qualquer forma, para seu perecimento. Pesa a favor desse entendimento o fato de que como a parte que destruiu a prova tinha ciência de seu conteúdo lhe é indubitavelmente mais fácil provar o respectivo conteúdo por intermédio da produção de outras provas. Basta cumprir com seu dever de colaboração com o descobrimento da verdade.

Vale ressaltar que a aplicação da teoria da dinamização do ônus da prova somente deve ser efetivada após restar comprovado que a prova foi destruída por ato culposo ou doloso de determinada parte.

Em suma, se restar demonstrado que a parte requerida, por ato culposo ou doloso, tornou a prova diabólica para a outra parte, deverá o magistrado aplicar a teoria da 
dinamização do ônus da prova, distribuindo o encargo da prova e de suas consequências a esta parte que violou os deveres de lealdade, probidade e de colaboração processual.

Resolvida a questão teórica do presente tema, resta analisá-lo sob o aspecto prático.

Necessário ainda estabelecer que não há confundir-se a presente questão com a presunção de veracidade gerada pelo disposto no artigo 359, caput do CPC, que versa sobre a exibição de documento ou coisa. Como detalhado anteriormente, ${ }^{343}$ presunção e distribuição do ônus da prova não se misturam, possuindo características e áreas de aplicabilidade distintas.

A dinamização do ônus da prova com base na destruição dolosa ou culposa da prova deve ser sempre provocada pela parte que entender prejudicada com o ato de destruição praticado pela outra parte. Afinal, se essa informação não chegar aos autos, o magistrado não terá ciência da destruição da prova e, regra geral, aplicará as consequências da ausência ou insuficiência da prova à parte originariamente onerada.

Retomando a metodologia exemplificativa, "A", autor, requer e alega que "B", requerido, lhe deve o cumprimento de uma obrigação oriunda de um contrato firmado entre ambos. Sustenta que esse contrato foi confeccionado em apenas uma via, a qual estava na posse do requerido. Narra ainda que este, na presença de terceiros, após uma discussão com o autor, justamente por não querer cumprir o avençado, o queimou. Insta ressaltar que esta abstrata hipótese não enseja a incidência do requisito geral da aplicação da dinamização do ônus da prova, consistente na maior facilidade de uma das partes produzir determinada prova, pois não seria crível, aqui, que o autor tivesse firmado um contrato com o requerido e não tivesse tido a cautela de guardar uma via consigo.

Mediante provocação da parte interessada, inicialmente onerada pela regra rígida do ônus da prova, o juiz, ao exercer o dever de informação específica, deverá advertir o requerido que poderá, na sentença, dinamizar o ônus dessa prova, aplicando-lhe suas respectivas consequências caso não produza a mencionada prova.

${ }^{343}$ Cf. Título II, seções 2.17 e 2.1.8. 
Entretanto, para que isso se concretize na sentença, o autor deverá, ainda, produzir a prova desse fato, i.e., que o requerido destruiu dolosamente a citada prova, produzindo a respectiva prova testemunhal, já que terceiro presenciou os fatos narrados.

Caso o autor, diante de outros casos concretos, não produza essa prova ou não consiga produzir prova suficiente do alegado ato de destruição praticado pela parte ex adversa, quer dolosa quer culposamente, o magistrado, sob esse argumento, não deverá aplicar a dinamização do ônus da prova. Esse modos operandi, regra geral, é aplicável a qualquer espécie de prova, tanto para a hipótese de destruição dolosa quanto para a culposa.

Essa prática gera maior celeridade e, assim, efetividade ao processo, pois não implica necessidade de incidentes processuais específicos e, ainda, oportuniza a parte que almeja a redistribuição do ônus probatório, com base no argumento da destruição da prova pela outra parte, aproveitar a própria fase probatória para demonstrar ao juiz a veracidade de suas alegações, i.e., que a outra parte destruiu prova essencial ao deslinde da demanda de maneira dolosa ou culposa, devendo, assim, ser aplicada a dinamização do ônus da prova no momento oportuno.

Ademais, respeitadas as peculiaridades e interesses de cada parte, em cada caso concreto, a mencionada prática, a priori, elimina grande de número de situações fáticas que implicariam necessidade de utilização do incidente processual instituído pelos artigos 355 e seguintes do $\mathrm{CPC}$, relativo à exibição de documento ou coisa, uma vez que o objetivo prático final será o mesmo, i.e., uma sentença favorável. ${ }^{344}$

\subsubsection{Dever de informação e aplicação da dinamização}

\footnotetext{
${ }^{344}$ Não se está defendendo a ausência absoluta de utilidade do incidente relativo à exibição de documento ou coisa, pois haverá casos em que este restará imprescindível aos interesses das partes.
} 
Foi visto anteriormente ${ }^{345}$ que o juiz tem o dever de informar às partes, diante do caso concreto, que ele poderá, ao proferir a sentença, aplicar a dinamização do ônus da prova, de forma fundamentada e, em seguida, utilizar a regra de julgamento pertinente ao ônus objetivo da prova.

Naquela oportunidade, foi afirmado, em síntese, que esse dever de informação consiste em verdadeira expressão do direito constitucional à prova, i.e., somente com o cumprimento pelo Estado-juiz desse dever é que estaria eficaz e plenamente efetivado o direito e garantia constitucional à prova. Afinal, como derivação dessa garantia de ordem constitucional, sob o ângulo dos sujeitos parciais, estes tem o direito de informação a respeito das provas essenciais a ser produzidas nos autos, para a formação do convencimento do magistrado, bem como as respectivas consequências caso optem por não fazê-lo, correndo o risco de sucumbir na demanda pela ausência de colaboração na produção da verdade.

Se por um lado, esse dever de informação do juiz consiste em uma das variáveis do direito constitucional à prova, por outro, especificamente no tocante à distribuição do ônus da prova de forma diversa da estipulada em lei, apresenta-se como corolário ${ }^{346}$ de outros dois princípios constitucionais umbilicalmente interligados: o da ampla defesa e o do contraditório.

Diante dessa derivação, verifica-se pertinente discorrer sobre os citados princípios. O contraditório, no sistema processual-constitucional vigente, não apenas qualifica, mas é elemento estrutural da composição do processo. Somente o procedimento regulado de tal forma que dele participem, em simétrica paridade, aqueles em cuja esfera jurídica o ato final produzirá efeitos, poder ser chamado de processo. Essa a diferença fulcral entre processo e procedimento. ${ }^{347}$

Ademais, o contraditório legitima a decisão final a ser tomada, ou seja, cumpre uma função social ao legitimar o processo, pois permite às partes poder influenciar no resultado

\footnotetext{
${ }^{345}$ Cf. Título I, seção 1.2.3.

${ }^{346} \mathrm{O}$ vocábulo corolário significa consequência, aquilo que se deduz de uma proposição já demonstrada, de uma regra estabelecida, de um princípio firmado. Cf. NUNES, Pedro dos Reis. Dicionário de tecnologia jurídica. 12. ed. Rio de Janeiro: Livraria Freitas Bastos S.A., 1993. p. 258.

${ }_{347}$ FAZZALARI, Elio. Istituzioni di diritto processuale. $8^{\mathrm{a}}$ ed. Padova: CEDAM, 1996. p. 82-83.
} 
final do processo, levando os litigantes ao compromisso de aceitação da decisão a ser proferida, imunizando o sistema social contra descontentamentos e protestos. ${ }^{348}$

Em uma concepção eminentemente técnica, o contraditório pode ser considerado como o melhor método para a descoberta da verdade dos fatos e para a justa aplicação do direito, uma vez que permite às partes contribuir de forma ímpar para tal, através da efetiva participação. Afinal, "se il processo serve alle parti, alla loro volta le parti servono ao processo.". 349

Em síntese, é possível afirmar que o contraditório consiste em garantia fundamental de imparcialidade, legitimidade e correção da prestação jurisdicional, estando expresso na nossa Carta Magna, artigo $5^{\circ}$, inciso LV. Processo sem contraditório não tem diálogo entre as partes e a decisão tende a ser unilateral, ilegítima e injusta. ${ }^{350}$

A concepção moderna da garantia da ampla defesa, expressamente consignada em nossa Constituição Republicana, em seu artigo $5^{\circ}$, inciso LV, compreende: “a) o direito de ser informado; b) a bilateralidade da audiência (contraditoriedade); e c) o direito à prova legitimamente obtida ou produzida.". 351

Não resta dúvida que o direito dos litigantes de ser informado, derivado do princípio constitucional da ampla defesa, não diz respeito somente ao ajuizamento da demanda, que se perfaz com a citação válida e regular, mas também se estende aos demais atos processuais, ${ }^{352}$ essencialmente aqueles que estejam ligados à possibilidade de contraditório e ao direito à prova. ${ }^{353}$

\footnotetext{
348 LUHMANN, Niklas. Legitimação pelo procedimento. Trad. Maria da Conceição Corte-Real. Brasília: Editoria Universidade de Brasília, 1980. p. 91 e ss.

349 CARNACINI, Tito. Tutela giurisdizionale e tecnica del processo. Studi in onore di Enrico Redenti. Milano: Giuffrè, 1950. p. 700.

${ }^{350}$ GOMES FILHO, Direito à prova..., 1997, p. 137.

351 TUCCI, Lauria; TUCCI, Constituição de 1988..., 1989, p. 61. Quanto ao direito de ser informado afirmam os autores que a tutela judicial eficaz de um direito subjetivo material reclama, sempre, a necessidade de informação, consoante as formas traçadas pelas normas processuais, ao titular da antagônica situação, abrangida pela relação jurídica cuja definição é solicitada ao agente do Poder Judiciário - juiz ou tribunal. Os autores se reportam, contudo, somente ao direito de ser informado do aforamento da ação. Ainda nesse sentido COUTURE, Eduardo J. Fundamentos del derecho procesal civil. 3. ed. Buenos Aires: Depalma, 1974. p. 150.

352 TUCCI, José Rogério Cruz e. Lineamentos da nova reforma do CPC. 2. ed. rev., atual. e ampl. São Paulo: Revista dos Tribunais, 2002. p. 101, afirma que impõe-se ao juiz, para evitar qualquer espécie de emboscada
} 
Em efeito, nesse particular, se a parte tem o direito de ser informada dos atos processuais, surge em contrapartida, o dever do órgão responsável pela jurisdição de informar, i.e., de prestar todas as informações necessárias a evitar a violação ao contraditório e ao direito à prova.

Nesse passo, o dever do magistrado de informar às partes quanto à possibilidade de aplicação da dinamização do ônus da prova no momento sentencial, na essência, apesar de não implicar comunicação de um ato processual concreto, pois sua ocorrência é futura e incerta, tem direta repercussão no princípio constitucional da ampla defesa e, assim, no contraditório e na ampla produção de prova.

Essa direta repercussão se evidencia de forma mais visível a partir do momento que o cumprimento desse dever pelo magistrado evita surpresas às partes (violação ao contraditório) e permite-lhes produzir todas as provas disponíveis, não podendo alegar que não as produziu com base na permissão da regra rígida do ônus da prova (violação ao direito à ampla produção de provas).

Apesar da concretização do ato informado, i.e., a aplicação da dinamização do ônus da prova na sentença depender de circunstâncias futuras e incertas, sua comunicação pelo juiz, no presente, gera efeitos teóricos e práticos imediatos no tocante à atitude probatória das partes. Em âmbito teórico, as partes passam a estar cientes de que a regra rígida de distribuição do ônus da prova pode ser dinamizada. Em âmbito prático, as partes modificarão seus comportamentos, ao menos poderão, quanto à produção da prova, passando a priorizar o descobrimento da verdade em detrimento de seu encobrimento.

O mesmo se pode afirmar quanto ao contraditório, uma vez que o cumprimento desse dever de informar do juiz retira a existência jurídica do elemento surpresa da relação processual em andamento, especificamente quanto à produção de provas, não podendo ser alegada como vício a embasar futuro acolhimento de recurso pelo órgão ad quem.

aos litigantes, o dever de comunicar às partes as vertentes que ele reputa relevantes para a formação de sua própria convicção.

${ }^{353}$ Nesse sentido NERY JUNIOR, Princípios do processo civil..., 1999, p. 129-130. 
Na doutrina e jurisprudência pátria abstrai-se outros exemplos de dever do juiz, que não se encontram positivados, derivados do princípio constitucional da ampla defesa e contraditório, mas que se apresentam assentados no direito processual civil de forma incontroversa. Ad ilustrandum, é pertinente trazer à baila a hipótese dos embargos de declaração com efeito infringente. ${ }^{354}$ Quando da interposição dessa modalidade de embargos, é dever do juiz informar à parte interessada, através dos meios regulares estabelecidos no CPC, que foi apresentado recurso de embargos de declaração com efeito infringente e que a mesma pode se manifestar no prazo legal. ${ }^{355}$

Demonstrando, ainda, que a informação do juiz às partes, quanto à plausível aplicação da teoria da dinamização do ônus da prova na sentença, diante do caso concreto, satisfaz a exigência constitucional da ampla defesa e do contraditório, insta ressaltar que esse ato praticado pelo juiz, além de informar à parte, dando efetiva ciência de tudo que se passa no processo e, particularmente, do que possa a vir acontecer em âmbito de ônus da prova, ${ }^{356}$ permite que as partes, já devidamente cientificadas, possam reagir, exercendo todo e qualquer ato pertinente à produção da prova. ${ }^{357}$

\footnotetext{
${ }^{354}$ Nesse sentido STJ. $1^{\text {a }}$ Turma. EDcl nos EDcl nos EDcl no AgRg no Ag 1058786/SP (2008/0123456-0). Rel. Min. Luiz Fux. Julgado em 18/11/2010. Publicado DJe em 01/12/2010; STJ. 6 ${ }^{\text {a }}$ Turma. AgRg nos EDcl no REsp 1019370/RS (2007/0309608-3). Rel. Min. Maria Thereza de Assis Moura. Julgado em 19/10/2010. Publicado Dje em 08/11/2010.

${ }^{355}$ Nesse sentido DINAMARCO, Cândido Rangel. Nova era do processo civil. São Paulo: Malheiros, 2003. p. 186-187. Afirma que repugna ao espírito e à garantia do due process o exercício do poder de julgar qualquer rercurso sem a resposta do recorrido, entre os quais os embargos declaratórios de objetivos infringentes, [...]. Se a lei ordinária não mandasse colher a resposta do recorrido à apelação, ao agravo, aos embargos infringentes etc., nem por isso poder-se-ia dispensar essa providência, que é sempre um ditame constitucional. Ainda OLIANI, José Alexandre Manzano. O contraditório nos recursos e no pedido de reconsideração. São Paulo: Revista dos Tribunais, 2007. p. 140-142. Afirma que quando os embargos de declaração assumem caráter infringente do julgado, deverá a parte contrária ser intimada para respondê-los, o que se alinha à feição moderna do contraditório. Também ASSIS, Araken de. Manual dos Recursos. 2. ed. rev., atual. e ampl. São Paulo: Revista dos Tribunais, 2008. p. 630-631. Sustenta que o princípio do contraditório há de ser sempre observado nos embargos de declaração, implicando sua preterição em nulidade do julgamento.

${ }^{356}$ Nesse sentido pertinente a lição de DINAMARCO, A Instrumentalidade..., 2008, p. 294. Afirma: "De minha parte, vou entendendo que o juiz deve estar atento às regras do ônus da prova e ao desempenho de cada uma das partes ao longo de toda a instrução da causa. A regra do diálogo, inerente à garantia constitucional do contraditório em sua feição moderna, integra o chamado ativismo judiciário e exige que o juiz esclareça as partes sobre os rumos da instrução, conclamando-as a complementar provas.". (transcrição ipsis litteris - grifos do autor).

${ }^{357} \mathrm{O}$ contraditório envolve, ademais, a possibilidade de efetiva participação dos interessados na produção das provas e, igualmente, o dever do juiz de permitir às partes, antes da sua produção, que apresentem os meios de prova que pareçam necessários, o que, sob um enfoque substancial, exige prévio conhecimento das regras acerca do ônus da prova. Cf. YARSHELL, Antecipação da prova..., 2009, p. 91.
} 
Por fim, importa registrar que o dever de informação do juiz às partes, como corolário do princípio constitucional da ampla defesa, contraditório, ampla produção da prova, bem como ainda do devido processo legal, justifica-se teoricamente, com maior intensidade, enquanto a teoria da dinamização do ônus da prova não for positivada.

A imprescindibilidade do cumprimento desse dever de informação, além da ausência de norma legal, decorre, ainda, do caráter excepcional da teoria da dinamização do ônus da prova - regra de exceção -, uma vez que esta não tem a pretensão de ser uma regra fixa sobre a distribuição do ônus da prova, devendo ser aplicada caso a caso, diante das peculiaridades do caso concreto. Em efeito, a melhor forma de sua cientificação às partes é também caso a caso, diante das peculiaridades do caso concreto.

Não obstante, o dever de informação sob menção poderá subsistir mesmo após a positivação da teoria da dinamização do ônus da prova, sendo que sua aplicabilidade pode se tornar prescindível de acordo com o modelo/forma que o legislador adotar ao introduzir a teoria sob enfoque no sistema processual civil brasileiro.

\subsection{Dever de informação e ônus subjetivo da prova}

O cumprimento do dever de informação do juiz às partes, sob análise, não apresenta qualquer vinculação teórica com o ônus subjetivo das partes. É possível afirmar, ainda, com elevada convicção, que seu exercício no procedimento, não modifica ou extingue qualquer elemento da composição conceitual do ônus subjetivo da prova e, em decorrência, não produz qualquer efeito direto ou indireto em relação à regra de conduta.

Quando o juiz, no momento oportuno, informa às partes que poderá aplicar a dinamização do ônus da prova ao proferir a sentença, está informando-as, em outras palavras, que caso essas não provem os fatos que alegaram e sua convicção não seja suficientemente formada, utilizará uma determinada regra de julgamento para que não prevaleça um non liquet. 
Em efeito, o juiz, ao informar as partes dessa possibilidade, diante do caso concreto, não efetiva qualquer modificação do ônus da prova subjetivo, i.e., não estabelece o que deve ser provado nem quem deve produzir a prova. A teoria da dinamização do ônus da prova diz respeito, exclusivamente, ao ônus objetivo da prova.

Sob outro aspecto, o dever sob enfoque é devido somente ao juiz, como expressão de uma imposição de ordem constitucional. É ele quem tem o dever de exercitá-lo, de cumpri-lo e, assim, observar a garantia da ampla defesa, contraditório e o amplo direito à prova. As partes, mesmo após seu regular cumprimento pelo juiz, continuam absolutamente livres para adotar a estratégia, em âmbito de produção probatória, estabelecida pela regra rígida de distribuição do ônus da prova, inclusive mantendo-se absolutamente inertes quanto à produção de qualquer prova ou não.

\subsection{Momento de cumprimento}

O momento adequado para o magistrado efetivar o dever de informação sob análise é, indubitavelmente, na fase do saneamento do processo. No procedimento ordinário, o momento devido dar-se-á na audiência preliminar, antes das partes requer e o juiz decidir sobre as provas a ser produzidas. No procedimento sumário, na audiência de conciliação, na qual o juiz decide a respeito da produção das provas requeridas na peça vestibular e na contestação.

Em sede de Juizado Especial Cível, ante a especialidade de seu microssistema processual, marcado pela informalidade e celeridade, o momento adequado para que o juiz cumpra o dever de informação sob análise é o da audiência de conciliação. Apesar desta não ser presidida por juiz togado ao qual, a priori, é exclusivamente atribuída tal análise, i.e., se no caso concreto é devida ou não a aplicação da teoria da dinamização do ônus da prova, deve o juiz togado, após as partes concluírem pela não realização de um acordo, exercitar o dever de informação, tomando este ato por termo. Procrastinar o exercício do 
dever de informar para a próxima audiência consiste em equívoco, pois é justamente o momento da efetiva produção da prova. ${ }^{358}$

Na denominada fase do saneamento, ambas as partes já iniciaram o contraditório, tendo, regra geral, no procedimento ordinário, apresentado suas principais peças: o autor, sua petição inicial e sua réplica, e o requerido, sua peça defensiva. Esses atos jurídicos favorecem o juiz em sua análise, pois lhe concedem elementos fáticos e argumentativos mais robustos e crivados pelo contraditório, mesmo que parcialmente realizado.

Necessário firmar a premissa de que o juiz, ao cumprir o dever de informar as partes, não estará valorando o conteúdo das provas já produzidas até a citada fase, v.g., prova documental juntada com a vestibular, mas averiguando, diante do contexto dos argumentos e das circunstâncias fáticas e jurídicas (direito material invocado pelas partes), se há uma plausibilidade, mutatis mutantis, um "fumus boni iuris" de, no momento sentencial, aplicar a teoria da dinamização do ônus da prova. Também não estará analisando a presença dos requisitos de aplicabilidade da teoria da dinamização, o que somente fará no momento do proferimento da sentença.

Não há que se confundir o acima afirmado com o fato do dever de informação ser corolário dos princípios constitucionais da ampla defesa, contraditório e ampla produção de prova. As afirmativas não conflitam. A do parágrafo anterior é relativa à situação que esse dever deve ser praticado pelo juiz e a segunda a origem e ratio desse dever.

Importante destacar ainda que como a informação prestada pelo juiz às partes diz respeito a uma hipótese futura e incerta, a qual depende do resultado da atividade probatória das partes para se concretizar (resultado negativo), não há qualquer óbice para que o magistrado modifique seu entendimento sobre a aplicação da dinamização do ônus da prova durante o transcorrer do procedimento.

\footnotetext{
358 Segundo o teor do Enunciado 53, ratificado pelo XXVII Fórum Nacional de Juizados Especiais FONAJE/2010, deverá constar da citação a advertência, em termos claros, da possibilidade de "inversão" do ônus da prova. Essa prática, que observa a estrita celeridade, em detrimento de outros princípios processuais, somente pode ser teoricamente pensada e sustentada, relativamente à teoria da dinamização do ônus da prova, a partir do momento em que esta ingressar definitivamente em nosso direito processual civil através de lei.
} 
É possível e comum, no dia-a-dia forense, que o juiz tenha avaliações diferentes sobre as diversas questões que dizem respeito à demanda, principalmente sobre o thema probandum e seu enquadramento jurídico, ${ }^{359}$ durante o percurso procedimental, principalmente após o encerramento da audiência de instrução e julgamento, momento no qual, regra geral, as circunstâncias fáticas já foram totalmente apresentadas e comprovadas pelas partes nos autos.

Essa mobilidade, ainda que meramente intelectiva do magistrado, além de ser característica marcante da teoria da dinamização do ônus da prova, corrobora ainda mais o acerto de ser o ato sentencial o momento adequado para aplicá-la. Geraria uma confusão teratológica, se o juiz dinamizasse o ônus da prova, de forma diversa, mais de uma vez, por decisão anterior à sentença no mesmo processo. Os prejuízos dessa postura foram demonstrados em seção anterior.

Desta forma, como esse dever de informação tem por conteúdo uma advertência de que o Estado-juiz, na sentença, poderá aplicar a teoria da dinamização do ônus da prova, as partes devem envidar todos os esforços para não deixar incertezas nos autos quanto à matéria fática.

Ad abundantiam, mesmo não se referindo especificamente à teoria da dinamização do ônus da prova, mas guardando pertinência direta com o tema do ônus da prova, vem ganhando força na doutrina pátria o entendimento de que é dever do juiz, na audiência preliminar, informar a cada parte o respectivo ônus da prova, advertindo-as quanto às consequências relativas às incertezas advindas da ausência de provas ou sua insuficiência. Essa evolução tem suporte na necessidade de se conferir maior transparência à conduta judicial, o que deriva da cláusula do due process of law e da garantia do contraditório. ${ }^{360}$

Quanto à forma de execução desse dever de informação pelo magistrado, conclui-se que o respectivo ato processual, consistente em um dever do magistrado em relação às partes, não guarda forma específica para ser realizado, como tem os demais atos

\footnotetext{
${ }^{359}$ Como exemplo, menciona-se a hipótese de ser controversa a posição da parte autora, quanto à alegação de se enquadrar no conceito jurídico de consumidor.

360 Cf. nota 358, onde consta o Enunciado 53 do FONAJE/2010. O teor do enunciado consiste na recomendação da aplicação prática de um dever de informação similar ao ora enfocado.
} 
processuais de natureza notificatória ou similar, v.g., a intimação. ${ }^{361}$ Apesar disso, deverá ser tomado por termo e executado, preferencialmente, na presença das partes - advogados no momento adequado, i.e., na audiência preliminar.

Contudo, por ser não imprescindível a presença dos advogados das partes na audiência preliminar, ${ }^{362}$ não havendo qualquer sanção direta de natureza processual às partes caso não compareçam, ${ }^{363}$ pode ocorrer que uma delas ou ambas não se faça presente ao referido ato. Nesta hipótese, deverá o magistrado cumprir seu dever de informação, consignando-o no respectivo termo de audiência preliminar. ${ }^{364} \mathrm{Em}$ efeito, ao intimar a parte ausente para a audiência de instrução e julgamento, deverá intimá-la ainda do inteiro teor do cumprimento do dever de informação do juiz, além das decisões interlocutórias proferidas na referida audiência preliminar, por uma das formas instituídas por lei para a intimação de atos processuais.

O fundamental é que nenhuma das partes tenha qualquer espécie de dúvida quanto à distribuição do ônus da prova, principalmente, quanto ao ônus que recai sobre si, em caso de ausência ou ineficiência de prova.

Esse dever de informação quanto à plausibilidade de aplicação da teoria da dinamização do ônus da prova, regra geral deve ser realizado ex officio ou pode ter origem em provocação das partes, através de petição escrita ou requerimento oral na audiência preliminar.

Hipótese que não pode deixar de ser considerada refere-se ao cumprimento do dever de informação sob investigação após a fase do saneamento.

\footnotetext{
361 CPC. Artigos 154; 234 a 242.

362 Nesse sentido TJSP. 34 Câmara de Direito Privado. Apelação 9046322-18 (2006.8.26.0000). Rel. Cristina Zucchi. Data do julgamento: 22/11/2010.

${ }^{363}$ Como consequência indireta de ordem processual para a ausência das partes na audiência preliminar podese mencionar a não produção de quaisquer outras provas que não tenham sido requeridas na petição inicial, contestação e réplica. Preclui para a parte ausente a oportunidade de apresentar agravo retido em face das decisões interlocutórias proferidas na mencionada audiência, v.g., deferimento/indeferimento de provas, deferimento/indeferimento de questões processuais.

${ }^{364}$ Nessas circunstâncias, em virtude do exercício do dever de informação do juiz quanto à plausibilidade de aplicação da teoria da dinamização do ônus da prova na sentença, o magistrado não deverá indeferir requerimento apresentado pela parte que não compareceu à audiência preliminar, quanto à produção de outras provas ainda não pleiteadas em seus articulados, exceto se a prova for flagrantemente procrastinatória ou fora do contexto dos fatos controvertidos anteriormente fixados.
} 
Como o direito não é uma ciência exata, sendo substancialmente uma ciência social, pode ocorrer que o magistrado somente vislumbre a plausibilidade de incidência da teoria da dinamização do ônus da prova durante ou após a audiência de instrução e julgamento ou, até mesmo, após a apresentação de memoriais.

Nessas circunstâncias, para não gerar nulidade caso entenda aplicar a teoria da dinamização na sentença, o juiz poderá, ainda assim, exercer o dever de informação às partes nessas fases do procedimento, a rigor, na fase instrutória ou até mesmo após seu encerramento. Contudo, deverá, ao assim proceder, indagar as partes, após esse dado processual novo, i.e., esse ato processual recém realizado, se desejam produzir outras provas.

Caso a resposta de uma ou de ambas as partes seja positiva e o requerimento de produção de prova seja pertinente às regras do direito processual, mormente a da utilidade, deverá deferir a produção da prova, reabrindo a fase instrutória.

Essa possibilidade, apesar de tardia, advém da não incidência da preclusão pro iudicato quanto ao dever sob enfoque, além da estrita observância à ampla defesa, contraditório e amplo direito à prova.

\subsection{Consequências da inobservância}

Considerando a circunstância do magistrado não cumprir o seu dever de informação na fase do saneamento, não poderá aplicar a teoria da dinamização do ônus da prova no momento sentencial, sob pena de causar efetivo prejuízo e, assim, nulidade.

Essa nulidade advém do prejuízo causado pela violação da ampla defesa e do contraditório, bem como do direito à ampla produção da prova pelas partes, e não pela aplicação da regra pertinente ao ônus da prova objetivo e subjetivo. 
Na essência, quando o juiz cumpre o mencionado dever, as partes passam a ter ciência que a regra rígida de distribuição do ônus da prova pode ser dinamizada e, assim, aquela parte inicialmente não onerada, pela incidência da teoria da dinamização, pode ser considerada onerada, sofrendo as consequências de sua inércia ou ineficiência probatória. Isso, como dito anteriormente, pode modificar a estratégia da atividade probatória das partes, sendo que não altera a liberdade de agir dessas.

Não é indevido ressaltar novamente que as partes devem produzir toda a prova que dispõem, em busca da verdade e em observância ao princípio da cooperação, da boa-fé, da lealdade e probidade processuais.

\subsubsection{Momento da aplicação da dinamização}

A dinamização do ônus da prova é uma teoria inserida nos contornos científicos do dogma do ônus da prova. Em efeito, como visto anteriormente, a doutrina estrangeira ${ }^{365}$ é praticamente uníssona ao definir ônus da prova como regra de julgamento. ${ }^{366}$ Pode-se afirmar que também a doutrina pátria, ainda que majoritariamente, tem entendimento idêntico, pois mesmo aqueles que enfatizam a face subjetiva do ônus da prova, como regra de conduta, não isolam o fenômeno em relação à face objetiva, ou seja, à regra de julgamento e, ainda, não afirmam, pois impossível, que ônus da prova não é regra de julgamento. ${ }^{367}$

\footnotetext{
${ }^{365}$ Cf. nota 124 , seção 2.1.3, Título II.

${ }^{366}$ A doutrina tradicional e majoritária ensina que o Estado-juiz, diante da prova frustrada, diante das regras rígidas que disciplinam a distribuição do ônus da prova, na fase de julgamento, ou seja, ao proferir a sentença, irá "sancionar" aquela parte que alegou, mas não provou, de acordo com a natureza do fato alegado, i.e., se constitutivo, modificativo, impeditivo ou extintivo.

${ }^{367}$ Nesse sentido MOREIRA, Notas sobre a inversão..., 1997, p. 305-308. Ainda, YARSHELL, Antecipação da prova..., 2009, p. 90, $92-93$ e 95. Sustenta, em relação ao tema, que as regras pertinentes ao ônus da prova são também determinantes da conduta das partes e que se relacionam, ainda que reflexamente, à produção da prova. Coerentemente com essa posição, afirma que a inversão do ônus da prova deve ser comunicada às partes em momento anterior ao ato de julgamento. Nesse passo enfatiza que a inversão do ônus da prova tãosomente no momento do julgamento não é compatível com a dimensão que se pretende dar à prova, como inerente às garantias da ação, da defesa e do contraditório. Ainda, MITIDIERO, Colaboração no processo..., 2009, p. 128-130.
} 
Diante disso, e sem qualquer lampejo de dúvida, até mesmo por decorrência de lógica jurídica, o momento de aplicação da teoria da dinamização do ônus da prova é o do ato sentencial.

Modificar essa estrutura procedimental e teórica implica alterar não só o momento da distribuição do ônus da prova, mas grande parte dos temas que dizem respeito ou se intercomunicam com a prova. ${ }^{368}$

Quem defender que qualquer espécie de modificação do ônus da prova, mesmo que com autorização do legislador, possa ser realizada em momento diverso ao do ato sentencial não pode, em efeito, sustentar, dentro dos rigores técnico-jurídicos, que ônus da prova é regra de julgamento. E, por sua vez, quem assim argumentar, estará afirmando que o fenômeno do ônus da prova só tem uma face, a subjetiva.

Assim, não há como sustentar que o momento de aplicação da teoria da dinamização do ônus da prova seja diverso ao do ato sentencial, sem quebrar a lógica, a coerência e até mesmo o próprio conceito técnico-jurídico de ônus da prova como regra de julgamento, como regra de juízo, sob pena de instituir no ordenamento jurídico, no seio da doutrina e jurisprudência, uma deformidade científica quanto ao dogma do onus probandi. Consequentemente, ad abundantiam, estar-se-ia esfacelando o milenar dogma do ônus da prova.

Afinal, regra de julgamento é regra de julgamento, i.e., incide no momento do julgamento, com a finalidade de evitar um non liquet. Regra de conduta é regra de conduta, i.e., incide em momento anterior ao julgamento e visa meramente direcionar, de forma facultativa, a conduta processual das partes. Não é o descumprimento da regra de conduta que gera sanção, até porque a regra de conduta, isolando o fenômeno do ônus da prova, exprime somente uma faculdade (sem sanção). Necessário repetir: o descumprir esta norma não gera qualquer sanção. A sanção advém do fato da parte onerada não conseguir provar o alegado, de manter-se inerte e, em efeito, não convencer o juízo da veracidade de suas alegações, já no contexto integralizado do fenômeno do ônus da prova.

\footnotetext{
${ }^{368}$ Reportando-se à conhecida metáfora para retratar a questão, há quem diga que o processo é como um jogo de xadrez: se uma peça é mexida, todo o jogo é modificado.
} 
Para comprovar a premissa supra, se o autor não produzir prova do fato constitutivo de seu direito, mantendo-se inerte, mesmo assim poderá sair "vencedor" da demanda, caso o requerido reconheça os fatos narrados pelo autor em confissão. Em efeito, não há qualquer sanção ao autor por sua conduta omissiva, por inobservar a regra de conduta, pois não será aplicada, in casu, a regra de julgamento.

Diante disso, necessário reafirmar, estabelecendo definitivamente a premissa no sentido de que o momento adequado para que o magistrado aplique a teoria da dinamização do ônus da prova, sempre de forma fundamentada, indubitavelmente, é no ato sentencial. $^{369}$

É no ato sentencial que o Estado-juiz irá averiguar e valorar, primeiramente o contexto probatório produzido e, em seguida, realizando exercício intelectivo e técnicojurídico, verificará e valorará os fatos que restaram provados e os que careceram de demonstração. Ato contínuo, em relação àqueles fatos em que as partes permaneceram inertes, não produziram qualquer espécie de prova ou em relação àqueles que foram insuficientemente demonstrados, verificará a quem incumbia o respectivo ônus probatório (avaliação e valoração da prova). Em sequência, diante de todo esse contexto, verificará se é ou não hipótese de aplicação da teoria da dinamização do ônus da prova, lembrando que o magistrado já havia exercido o seu dever de informação, preferencialmente na fase procedimental do saneamento. ${ }^{370}$

Assim, o Estado-juiz somente deverá aplicar a teoria da dinamização do ônus da prova se for hipótese de utilização da regra de julgamento e se estiver presente ao menos um dos requisitos exigidos para a mencionada aplicação, conforme anteriormente discriminados, observando ainda os limites estabelecidos a sua aplicação, que serão adiante analisados.

\footnotetext{
${ }^{369}$ Substancialmente nesse sentido BARBERIO, Cargas probatorias dinámicas: qué debe probar..., 2008, p. 105-107. Afirma o autor que se "las cargas probatorias dinámicas son sana crítica y si ésta es valoración y razonamiento judicial, no podrá arribarse a tal juicio sino al sentenciar.”.

${ }^{370}$ Cf. seção 3.2.2.2 et seq.
} 


\subsection{Aplicação da dinamização em sede recursal}

A teoria da dinamização do ônus da prova pode ser aplicada integralmente pelo juízo ad quem, desde que o órgão julgador recursal, monocrático ou colegiado, diferentemente do juízo a quo, vislumbre a presença de um dos requisitos exigidos para a aplicação da teoria e observe os respectivos limites para sua aplicação.

Assim, não há qualquer óbice para o acolhimento da teoria, pelo juízo ad quem, ex officio, por se tratar de matéria de ordem pública. Também não há óbice teórico para o acolhimento da teoria quando a provocação advém da parte recorrente, ao apresentar como fundamento de seu recurso a existência de efetivo prejuízo em virtude da não aplicação, ou vice-versa, pelo juízo a quo, da teoria da dinamização do ônus da prova.

Nesta seara, o órgão ad quem pode se deparar com quatro situações diversas: a) tanto o dever de informação do juiz, ${ }^{371}$, quanto a teoria da dinamização não foram aplicados, e vislumbra-se devida a sua aplicação; b) o dever de informação do juiz não foi cumprido, mas o juízo a quo, mesmo assim, aplicou a teoria ao proferir a sentença; c) o dever de informação do juiz foi cumprido, mas este não aplicou a teoria na sentença, incidindo aí o fundamento da reforma e; d) ambos foram aplicados, mas vislumbra-se incorreta sua aplicação.

Quando o juízo a quo, na sentença, aplicar a teoria da dinamização do ônus da prova, sem ter cumprido o respectivo dever de informação, entende-se haver um vício insanável, por violar a ampla defesa, o contraditório, o direito à prova e, assim, o devido processo legal. Nesta hipótese, o juízo ad quem deverá anular a referida sentença e determinar a devolução dos autos ao juízo a quo para que este possa cumprir o respectivo dever e, ato contínuo, indagar às partes quanto à produção de novas provas, produzindo-as caso requerido e, posteriormente, proferir novo julgamento. ${ }^{372}$

\footnotetext{
${ }^{371}$ Em face do cumprimento pelo juiz do respectivo dever de informação não cabe qualquer recurso, pois seu teor não tem qualquer conteúdo decisório, não se tratando, assim, de decisão.

${ }^{372}$ Regra geral, não incide o teor do parágrafo quarto, do artigo 515 do CPC, por se tratar de vício insanável.
} 
Quando o órgão ad quem entender ser hipótese de aplicação da teoria da dinamização do ônus da prova, não aplicada pelo juízo a quo, apesar deste ter cumprido o respectivo dever de informação, o juízo ad quem deverá, simplesmente, corrigir o equívoco, fazendo prevalecer seu entendimento. Assim, o órgão recursal ao aplicar a teoria da dinamização irá proferir acórdão - decisum - integrativo ou substitutivo da sentença recorrida, não sendo devida a remessa dos autos ao juízo a quo para proferir nova sentença.

Entretanto, nesta hipótese, pode surgir uma variável com dois desdobramentos. Quando o juízo a quo cumprir o dever sob menção tardiamente, i.e., durante a audiência de instrução e julgamento e não tiver indagado às partes quanto à necessidade de produção de novas provas, entende-se que incide para essas a preclusão consumativa. Isso se torna claro a partir do momento que as partes, após tomar ciência das informações, não requerem a produção de novas provas e prosseguem praticando atos no processo como, v.g., a apresentação de memoriais. Diante disso, deverá o órgão ad quem, simplesmente, caso assim entenda, corrigir o equívoco, proferindo diretamente o decisum.

Todavia, quando o juízo a quo cumprir o dever sob menção após a apresentação de alegações finais (orais ou escritas) e não tiver indagado às partes quanto à necessidade de produção de novas provas e, em seguida, aplicar a teoria da dinamização do ônus da prova na sentença, entende-se haver um vício insanável, pelos motivos acima expostos, devendo a sentença ser anulada e os autos devolvidos ao juízo a quo para que indague às partes quanto à produção de novas provas, produzindo-as caso requerido e, posteriormente, proferir novo julgamento.

Importantíssimo fixar a premissa de que a existência desse vício insanável não deriva da aplicação da regra de julgamento, bem como da aplicação da teoria da dinamização do ônus da prova no momento sentencial, mas sim da violação do direito das partes à ampla produção de prova e da violação ao princípio da ampla defesa e contraditório, originada pelo não cumprimento do dever de informação do juiz, às partes, quanto à plausível aplicação da teoria da dinamização do ônus da prova e suas respectivas consequências.

Em síntese, pode-se afirmar que existem dois fundamentos distintos entre si que justificam a reforma da sentença: a) a aplicação indevida da regra de julgamento, fulcrada 
na teoria da dinamização do ônus da prova, consistindo em vício sanável pelo órgão ad quem e, b) a violação do devido processo legal (ampla defesa, contraditório e direito à prova), pela inobservância do analisado dever de informação às partes e suas respectivas consequências, consistindo em vício insanável pelo juízo ad quem.

Não obstante, uma solução alternativa, fulcrada precipuamente nos princípios da celeridade e economia processual, vem sendo adotada por alguns órgãos recursais que determinam a reabertura da instrução probatória, produzindo provas no próprio órgão $a d$ quem, inclusive em alegações de cerceamento de defesa e do direito à prova, com fulcro no $\S 4^{\circ}$ do artigo 515 do $\mathrm{CPC}{ }^{373}$ sem que isso implique supressão de instância quando do proferimento do acórdão. ${ }^{374}$ Esta posição, todavia, não é pacífica, ${ }^{375}$ pois a produção de provas na segunda instância ainda encontra óbices tanto de cunho teórico (vício insanável) quanto prático.

Entretanto, nas hipóteses mencionadas anteriormente, apesar do vício ser insanável, ${ }^{376}$ pode-se sustentar que o órgão ad quem, ao invés de determinar a devolução imediata dos autos à primeira instância, determine primeiramente a intimação das partes para se manifestar quanto à necessidade de produção de novas provas. Caso a resposta seja negativa estaria o juízo ad quem, então, apto a proferir o respectivo julgamento.

\footnotetext{
${ }^{373}$ Resta assentado que a norma inserta no $§ 4^{\circ}$ do artigo 515 do CPC, pela qual em caso de nulidade sanável devem as partes ser intimadas para procederem à corrigenda, não se aplica às instâncias extraordinárias, devendo o recurso estar perfeito, completo e acabado no momento de sua interposição perante os Tribunais Superiores. Nesse sentido STJ. Corte Especial. AgRg nos EREsp 932702/AL (2008/0265525-9). Rel. Min. Francisco Falcão. Julgado em 16/09/2009. Publicado DJe em 19/10/2009; STJ. $2^{a}$ Turma. REsp 1048954/PR (2008/0083097-5). Rel. Min. Mauro Campbell Marques. Julgado em 18/09/2008. Publicado Dje em $29 / 10 / 2008$.

${ }^{374}$ Nesse sentido JORGE, Flávio Cheim. Teoria geral dos recursos cíveis. 4. ed. rev., atual. e ampl. São Paulo: Revista dos Tribunais, 2009. p. 309.

${ }^{375}$ No sentido da devolução dos autos ao juízo a quo: TJSP. $13^{\mathrm{a}}$ Câmara de Direito Privado. Apelação com Revisão 9207273-78 (2009.8.26.0000). Rel. Cauduro Padin. Data do julgamento: 12/08/2009; TJSP. 12a Câmara de Direito Privado A. Apelação 9079072-83 (2000.8.26.0000). Rel. Nuncio Theophilo Neto. Data do julgamento: 29/02/2008; TJSP. 12 ${ }^{\text {a }}$ Câmara de Direito Privado. Apelação 9054032-65 (2001.8.26.0000). Rel. Ribeiro de Souza. Data do julgamento: 17/10/2007; TJSP. 23ª Câmara de Direito Privado. Apelação sem Revisão 9198574-74 (2004.8.26.0000). Rel. Rizzatto Nunes. Data do julgamento: 11/10/2006.

${ }^{376}$ Nesse sentido OLIVEIRA, Gleydson Kleber Lopes de. Apelação no direito processual civil. São Paulo: Revista dos Tribunais, 2009. p. 217-218. Afirma que tanto no cerceamento do direito de defesa quanto do direito à prova, há nulidade absoluta do feito. Sustenta ainda que mesmo nesses casos, é lícito ao tribunal converter o julgamento em diligência, com vistas a se produzir provas que, inclusive, podem ser delegadas ao juízo a quo ante aplicação analógica do artigo 492 do CPC.
} 


\subsection{Aplicação da dinamização antes da sentença: impedimento teórico}

Algumas vozes na doutrina e na jurisprudência pátria ${ }^{377}$ vem sustentando, mesmo que minoritariamente, que a "inversão",378 do ônus da prova deve ocorrer em momento procedimental anterior ao da sentença. ${ }^{379}$

Em relação à teoria da dinamização do ônus da prova, há quem trilhe o mesmo caminho, defendendo que o momento adequado para a aplicação da dinamização, regra geral, deve ser anterior ao da sentença e, especificamente, na audiência preliminar. ${ }^{380}$

Em apertada e objetiva síntese, tais juristas respaldam essa tese em dois argumentos principais, sendo um de natureza constitucional e outro de natureza sistêmica. O mais robusto, não obstante o mais perigoso, por aglutinar adeptos mais facilmente e, assim, necessitar de uma análise mais profunda, consiste na afirmativa de que a dinamização do ônus da prova, no momento da sentença, causaria surpresa às partes, principalmente àquela

\footnotetext{
377 A menção relativa ao momento da "inversão" do ônus da prova trás subsídios de análise para a presente pesquisa, pois consiste em uma forma de modificação judicial do ônus da prova: STJ. $4^{\text {a }}$ Turma. REsp 881651/BA (2006/0194606-6). Rel. Min. Hélio Quaglia Barbosa. Julgado em 10/04/2007. Publicado DJe em $21 / 05 / 2007$. Insta registrar, todavia, que o entendimento contrário, sendo o ato sentencial o momento adequado da 'inversão' do ônus da prova, é o majoritário naquela Corte: STJ. $3^{\text {a }}$ Turma. AgRg nos EDcl no Ag 977795/PR (2007/0269695-9). Rel. Min. Sidnei Beneti. Julgado em 23/09/2008. Publicado DJe em 13/10/2008; STJ. $3^{\text {a }}$ Turma. REsp 974994/SP (2007/0182927-7). Rel. Min. Nancy Andrighi. Julgado em 05/06/2008. Publicado DJe em 03/11/2008; STJ. $3^{\text {a }}$ Turma. REsp 949000/ES (2007/0105071-8). Rel. Min. Humberto Gomes de Barros. Julgado em 27/03/2008. Publicado DJe em 23/06/2008; STJ. $3^{\text {a }}$ Turma. REsp. 422.778-SP. Rel. originário Min. Castro Filho, Rel. para acórdão Min. Nancy Andrighi. Julgado em 19/6/2007. (posição pacífica na $3^{\text {a }}$ Turma do STJ).

${ }^{378}$ Insta registrar, para evitar confusão, que a referência à "inversão" do ônus da prova e ao momento de sua aplicação, nesta seção, tem a finalidade de expor os argumentos da doutrina e jurisprudência e, em seguida, após análise crítica, abstrair os elementos teóricos que possam ser utilizados em relação à teoria da dinamização do ônus da prova, objeto desta pesquisa.

${ }^{379}$ Cf. nota 273 .

${ }^{380}$ Nesse sentido, MITIDIERO, Colaboração no processo..., 2009, p. 128-130. Defende que a dinamização se dê preferencialmente na audiência preliminar (artigo 331, CPC), mas não vê óbice que o juiz a dinamize em momento posterior desde que reabra a fase instrutória, a fim de não se ferir o direito fundamental à prova no processo civil. Ainda MARINONI, Luiz Guilherme; MITIDIERO, Daniel. Código de processo civil comentado artigo por artigo. 2. ed. rev. atual. e ampl. São Paulo: Editora Revista dos Tribunais, 2010. p. 335-336. Sustentam que o ideal é que essa organização do processo em tema de prova se dê no quadro da audiência preliminar, oralmente, em regime de diálogo entre as pessoas do juízo, ou, por escrito, à semelhante altura do processo. E continuam afirmando que nada obsta [...] que se dinamize o ônus da prova em momento posterior, dês, é claro, que se lhe acompanhe a correlata oportunidade de provar. Vale dizer: em sendo o caso, reabra-se a fase instrutória, a fim de não se ferir o direito fundamental à prova no processo civil. Também CARPES, Artur Thompsen. A prova e participação no processo civil: a dinamização dos ônus probatórios na perspectiva dos direitos fundamentais. 2008. 176 f. Dissertação (Mestrado) - Programa de Pós-Graduação em Direito, Faculdade de Direito, Universidade Federal do Rio Grande do Sul, Porto Alegre. p. 147-152.
} 
que foi onerada pela respectiva decisão no bojo da sentença, ferindo o princípio fundamental do processo civil consistente no devido processo legal e o princípio constitucional da ampla defesa e contraditório. O segundo consiste na afirmativa de que se deve dar ênfase ao ônus subjetivo da prova em detrimento do objetivo, ou seja, à regra de procedimento, também denominada regra de conduta. ${ }^{381}$

Antes de demonstrar que tais argumentos não são suficientes a balizar a consequência almejada por aqueles, ou seja, permitir que a dinamização do ônus da prova e, pegando carona no raciocínio, também a "inversão" do ônus da prova, seja efetivada em momento procedimental anterior ao da sentença, insta apresentar os argumentos que sustentam a tese contrária, i.e., a tese ora propugnada.

Não obstante, importa desde já afirmar que os argumentos teórico-jurídicos utilizados por quem sustenta que a dinamização do ônus da prova deve ser aplicada em momento diverso ao da sentença não são suficientes a manter a unidade sistêmica, a coerência teórico-jurídica quanto ao dogma do ônus da prova e, como se não bastasse, ao contrário do que pregam, proporcionam uma insegurança jurídica ímpar em relação à produção da prova e a própria tutela jurisdicional, ao permitir que o juiz dinamize o ônus da prova um número indeterminado de vezes, no bojo do mesmo processo, uma vez que não há como sustentar a incidência de preclusão pro iudicato em face desse ato judicial.

Ademais, os que sustentam que a dinamização do ônus da prova deve ser aplicada em momento diverso ao da sentença, ignoram o relevante fato jurídico de que esta teoria está calcada na perspectiva cooperativa-solidarista do processo, tendo as partes o dever de

\footnotetext{
${ }^{381}$ YARSHELL, Antecipação da prova..., 2009, p. 60, 68-69, 89 e 112, propõe uma verdadeira ruptura entre ônus da prova e julgamento estatal, i.e., entre ônus da prova subjetivo e objetivo. Essa ruptura estaria sustentada no seguinte raciocínio: "a pretendida desvinculação [...] parece partir da visão, que já se apontou ser incompleta, de que a prova - incluindo-se, aí, as regras sobre a distribuição do respectivo ônus - tem como destinatário exclusivo o juiz e de que a valoração daquela só se faz pelo agente estatal. Tal idéia, recorrente na doutrina processual, parte da premissa, [...] de que a função da prova é apenas a de convencer o magistrado a cerca dos fatos. Daí se explica a tendência de colocar o juiz "no centro do problema probatório.". Em síntese, sustenta que também as partes são destinatárias da prova e das regras de distribuição do ônus da prova e que também elas valoram o resultado das provas. E continua: "Isso não parece ser exato, porque, antes ou mesmo durante o processo, a prova produzida [...] dirige-se também à formação do convencimento das partes a propósito de suas chances de êxito, sendo, assim, determinante de suas condutas.". Portanto, [...] a consideração de seu ônus de provar é indissociável da valoração que possam fazer acerca das provas produzidas, ou daquela que projetem possam ainda produzir. As partes só podem avaliar se tais ou quais meios de prova foram - ou melhor ainda, se serão - suficientes para as desincumbir dos respectivos ônus se e na medida em que fizerem um juízo de valor acerca daqueles (ainda que, por seu turno, façam-no projetando a valoração que o juiz, ao julgar, faria ou fará).”. (transcrição ipsis litteris).
} 
colaborar para o descobrimento da verdade. Conscientes desse dever, essas não devem se eximir de produzir todas as provas disponíveis para a formação do convencimento do magistrado em conformidade com a verdade. A isso, se contrapõe a visão privatista-liberal que parece ainda prevalecer na tese contrária.

E mais, conscientes que o Estado-juiz, na sentença, poderá aplicar a teoria da dinamização do ônus da prova, a não produção de uma prova disponível consistirá uma estratégia suicida para a respectiva parte que tinha facilidade em produzi-la e não o fez deliberadamente.

Ao aplicar a teoria da dinamização dos ônus probatórios na sentença ou no acórdão, o Estado-juiz não estará, ao agir assim, ferindo quaisquer das garantias fundamentais de ordem constitucional processual como a da ampla defesa e do contraditório, da paridade de armas, enfim, do devido processo legal, pois, além de ter cumprido o dever de informação sobre a possibilidade de aplicação da teoria no momento oportuno - ato sentencial -, o próprio dogma do ônus da prova já traz em seu bojo a informação às partes de que essa regra será aplicada caso a parte onerada não consiga produzir prova hábil a formar o convencimento do julgador. $^{382}$

Assim, se o magistrado cumpre de forma efetiva e plena seu dever de informação às partes de que poderá, na sentença, aplicar a dinamização, dando amplíssima ciência a elas, preferencialmente na fase do saneamento, esclarecendo todas as consequências quanto as suas condutas comissivas e omissivas e todo o proceder do juízo em relação à aplicação da teoria da dinamização do ônus da prova, não há como alegar, mormente diante da concepção cooperativa-solidarista de processo, qualquer tipo de surpresa quanto à distribuição do ônus da prova na sentença e, ainda, quanto à possibilidade de ampla produção da prova, ${ }^{383}$ pois, o juízo estará, além de informando de forma plena e irrestrita,

\footnotetext{
${ }^{382}$ Nesse sentido ARENHART, Ônus da prova..., 2009, p. 335. Defende que "não se pode falar em lesão à ampla defesa e ao contraditório em razão da modificação dos critérios do ônus da prova, sendo a regra, naturalmente, destinada a incidir quando do julgamento da causa. Não há lesão a tais garantias constitucionais simplesmente pelo fato de que as partes não tem disponibilidade sobre as provas que detém e que são de interesse do processo".

${ }^{383}$ Substancialmente nesse sentido, mas sob outro argumento ARENHART, Ibid., p. 336. Afirma que não há falar-se em surpresa da parte, diante da inversão do ônus da prova em seu prejuízo, pois, se a respectiva parte não produziu a prova que poderia fazer faltou ela com seu dever processual, não podendo esta omissão ser invocada em seu benefício.
} 
oportunizando as partes também de forma plena e irrestrita, a produção de todas as provas que desejarem, visando estabelecer que suas alegações são as verídicas.

Como se não bastasse, a teoria da dinamização do ônus da prova, ao identificar e enfatizar como elemento estrutural, o dever de informação do magistrado, quanto a sua possibilidade de aplicação na sentença, amplia não só a cientificação dos atos processuais presentes e futuros, quanto o grau de participação das partes no processo e, via de consequência, torna absolutamente efetiva a ampla defesa e o contraditório. Não é demais afirmar que a ampla defesa e o contraditório significam efetiva ciência e oportunização, e não a obrigação da parte quanto ao concreto exercício de determinado ato processual. ${ }^{384} \mathrm{Se}$ fosse diferente, o não exercício da resposta consistiria em violação a tais princípios constitucionais, mesmo diante da citação válida e regular. ${ }^{385}$

Afinal, no bojo do Estado Democrático de Direito o que legitima o exercício e o resultado dos atos processuais é a oportunidade de participação dos interessados. A participação é uma exigência de cunho político cuja expressão jurídica é o contraditório. ${ }^{386}$

Não há que se falar que a parte será, assim, obrigada a produzir prova contra si. Definitivamente não se trata disso, é uma leitura equivocada da teoria sob enfoque. Como esclarecido anteriormente, ao dinamizar o ônus da prova, o magistrado não imputará ao réu o ônus da produção da prova constitutiva do direito do autor e, muito menos, imputará ao autor o ônus da produção da prova desconstitutiva lato sensu de seu próprio direito, o que seria algo teratológico. Irá, sim, onerar quem tem mais facilidade na produção da prova e desonerar quem tem mais dificuldade em sua produção, respeitando a natureza dos fatos a ser provados: constitutivos e desconstitutivos lato sensu. Na prática, dentro dos requisitos

\footnotetext{
${ }^{384}$ Nesse sentido DINAMARCO, Instituições..., 2009, v. 1, p. 220. Afirma que a "garantia do contraditório, imposta pela Constituição com relação a todo e qualquer processo - jurisdicional ou não (art. $5^{\circ}$, inc. LV) significa em primeiro lugar que a lei deve instituir meios para a participação dos litigantes no processo e $o$ juiz deve franquear-lhes esses meios". (transcrição ipsis litteris - grifos do autor). Ainda OLIVEIRA, Garantia do contraditório, 1999, p. 144. Sustenta, ao discorrer sobre o conteúdo mínimo do princípio do contraditório, que "também se revela imprescindível abrir-se a cada uma das partes a possibilidade de participar do juízo de fato, tanto na indicação da prova quanto na sua formação,..." (Transcrição ipsis litteris). ${ }^{385}$ Ainda DINAMARCO, Ibid, v. 1, p. 223: "Atenta a esse quadro de participação dos litigantes, a doutrina vem há algum tempo identificando o contraditório no binômio informação-reação, com a ressalva de que, embora a primeira seja absolutamente necessária sob pena de ilegitimidade do processo e nulidade de seus atos, a segunda é somente possível. No processo de conhecimento, o réu que não oferece constatação considera-se revel [...]. Nem por isso, contudo, peca esse processo por falta de contraditório". (transcrição ipsis litteris - grifos do autor).

${ }^{386}$ Nesse sentido DINAMARCO, A instrumentalidade..., 2008, p. 155-156.
} 
explicitados anteriormente e das limitações a seguir mencionadas, o magistrado irá onerar o réu quanto às consequências da não produção da prova impeditiva, modificativa, extintiva do direito do autor sem que o autor tenha que arcar com as consequências da não produção dos fatos constitutivos de seu direito.

Outro argumento que não pode ser desconsiderado diz respeito à qualificação técnica dos operadores do direito. Não é correto sustentar, sob pena de sua desqualificação técnica, que todos os profissionais da área jurídica, v.g., advogados privados e ocupantes de cargos públicos, membros do Ministério Público, integrantes de carreiras afins e outros, desconhecem essas regras e, assim, seriam surpreendidos pela aplicação do contexto teórico da distribuição dinâmica do ônus da prova.

Necessário, doravante, abrir parêntese para retornar a alguns pontos anteriores.

Ad abundantiam e retornando à já mencionada e analisada "inversão" do ônus da prova, ${ }^{387}$ positivada no CDC, para fins de aproveitamento dos argumentos teóricos na sustentação da tese ora propugnada, minoritárias vozes da doutrina ${ }^{388}$ defendem que o momento adequado para que o juiz "inverta" o ônus probatório, no direito processual civil brasileiro, situa-se na audiência preliminar - rito ordinário -, disciplinada no artigo 331, § $2^{\circ}$ do CPC, e, com precisão cirúrgica, logo após o juiz fixar os pontos controvertidos, mas antes de deferir ou indeferir as provas requeridas pelas partes.

Sustentam ainda que somente após essa decisão do juiz que determina, na audiência preliminar, a "inversão" do ônus da prova é que cada parte teria efetivas condições de avaliar o conjunto de sua atividade probatória, quais meios de prova lhes seria útil e, por fim, especificar as provas que desejariam produzir. Somente a partir desse momento, desse decisum, é que as partes teriam plena ciência das consequências processuais que lhes incidiria caso permanecessem inertes ou produzissem prova insuficiente.

\footnotetext{
${ }^{387}$ Cf. Título III, seção 3.2.1.4.

${ }^{388}$ Essencialmente nesse sentido MOREIRA, Notas sobre a inversão..., 1997, p. 305-308. Contra, ratificando a posição majoritária, GRINOVER, Código brasileiro..., 2005. Às fls. 796 da citada obra, Kazuo Watanabe manteve posição firmada na p. 734 , da $6^{\mathbf{a}}$ edição da referida obra, editada em 1999 , quanto ao momento da inversão do ônus da prova ser o da sentença - regra de julgamento. Faz importante e enfática menção, aderindo assim ao mesmo posicionamento, à dissertação de Cecília Matos, que afirma que a inversão do ônus da prova no momento do julgamento não viola o contraditório.
} 
Este entendimento apresentado pela doutrina, originariamente quanto à "inversão" e posteriormente adaptado à dinamização do ônus da prova que, prima oculi, consiste em um avanço técnico-jurídico sob o aspecto da observância das garantias fundamentais constitucionais na seara processual, mormente quanto à garantia da ampla defesa e contraditório, sob o argumento principal de coibir surpresas para as partes, na realidade, está eivado de equívocos de ordem teórica com sérias consequências práticas.

O primeiro deles é confundir os fenômenos do ônus da prova objetivo com o subjetivo. Conforme anteriormente especificado, se o magistrado dinamiza o ônus da prova, que é objetivo, durante o procedimento, este não pode ser mais considerado objetivo, pois não estará o magistrado aplicando regra de julgamento.

Esse entendimento ainda confunde e conjuga dois outros fenômenos processuais absolutamente diversos: o da valoração da prova com o do ônus da prova. Na essência, seguindo o raciocínio jurídico implementado acima, ao aplicar a dinamização durante o procedimento, o juiz estará valorando circunstâncias fáticas futuras e incertas, bem como um resultado probatório igualmente incerto, advindo de uma produção de prova também incerta, pois nada garante, por ser uma faculdade, que a parte efetivamente a produza. É assentado na seara empírica, em âmbito de direito processual, que nem mesmo as próprias partes, produtoras das provas em juízo, tem o condão de saber o seu resultado. Elas apenas conseguem prever, i.e., fazer um juízo de mera previsão. ${ }^{389}$

Definitivamente, o ônus da prova objetivo, regra de julgamento, não diz respeito à valoração de provas, incidindo justamente em momento posterior a essa atividade intelectiva realizada pelo próprio juiz.

Ademais, essa tese e seu respectivo raciocínio jurídico, no tocante ao momento adequado para o juiz dinamizar ou "inverter" o ônus da prova, ou seja, na audiência preliminar, i.e., antes do momento sentencial, não coaduna com o sistema jurídico dos países de civil law, inclusive o nosso, pois assim agindo, estaria o magistrado repartindo o ônus da prova baseado em razões de verossimilhança do caso concreto, formando um

\footnotetext{
389 Nem as partes, nem o juiz, nem mesmo o perito, antes de concluir seus trabalhos sabem os seus resultados. Nesse sentido, somente após a oitiva de uma testemunha é que a própria parte que a arrolou fica ciente, de forma precisa, do resultado da produção da prova dessa prova testemunhal.
} 
convencimento ou anterior ou paralelo à repartição do referido ônus, tornando impossível saber onde termina o convencimento e onde começa a repartição do ônus da prova. Isso não ocorre quando a dinamização do ônus da prova é efetivada na sentença, após o encerramento da fase de avaliação da prova e formação do convencimento do juiz. ${ }^{390}$

Outro equívoco insustentável teoricamente diante de nosso direito constitucional e processual civil consiste no fato de que, a prevalecer esse entendimento, o juiz estaria, em âmbito probatório, implementando um exímio sistema inquisitivo puro, pois poderia determinar, antes da fase probatória, ou seja, antes de permitir às partes o livre e pleno exercício de suas atividades nessa seara, quem, i.e., qual delas, deveria produzir o que, i.e., qual prova. Isso fere frontalmente o sistema dispositivo, atualmente mitigado e equilibrado.

Além disso, como frisado em passagem anterior, tal posicionamento, em sua essência, é calcado em uma visão privatista do processo, respaldando o egoísmo e a irresponsabilidade das partes para com a verdade e para com o próprio processo e a tutela jurisdicional. Ademais, não é supérfluo repetir que esse mesmo entendimento não coaduna com o dever de colaboração da parte quanto ao descobrimento da verdade.

Por mais paradoxal que possa parecer, todo dever de colaboração, inclusive o relativo ao descobrimento da verdade, tem por pressuposto uma atividade calcada na liberdade de escolha, jamais em uma imposição, pois, se assim fosse, passaríamos ao campo da obrigação, i.e., as partes seriam obrigadas a produzir a verdade.

Necessário ressaltar, sempre, que a teoria da dinamização do ônus da prova tem por um dos elementos estruturais o dever de informação às partes, explicitado em seção anterior, que cumpre essa obrigação de evitar surpresas às partes e, assim, primar pela observância aos princípios constitucionais da ampla defesa, contraditório, ampla produção de prova e, em síntese, ao princípio fundamental do processo civil: o devido processo legal.

\footnotetext{
${ }^{390}$ ROSENBERG, La carga..., 2002, p. 36, já advertia que o perigo de se confundir o ônus da prova com a apreciação da prova somente existe na esfera do ônus subjetivo da prova, não sendo possível tal discussão na seara do ônus objetivo da prova. (tradução nossa).
} 
Outro problema de elevada grandeza relativamente ao entendimento sob análise diz respeito ao prejuízo que causaria à celeridade e efetividade do processo. Caso prevalecesse esse entendimento, os Tribunais Superiores e Tribunais de Justiça, não poderiam aplicar a dinamização do ônus da prova ao proferir o julgamento do mérito recursal, pois, em tese, seriam obrigados a anular a sentença e remeter os autos para que o juízo a quo aplicasse a dinamização, uma vez que deveria ocorrer antes da fase de produção de provas.

Não seria hipótese de incidência do disposto no artigo 515, parágrafo quarto do CPC, uma vez que o vício acima mencionado atingiria toda a instrução probatória e não parte dela, tornando inviável a realização da maior fase procedimental, a instrução probatória, perante o juízo ad quem que, além de não possuir essa atribuição precipuamente, não apresenta estrutura física para tal. Agrega-se a esses posicionamentos, o argumento de que a realização de toda a fase da instrução probatória, no juízo ad quem, configura supressão de instância.

Como se não bastasse, essa decisão de "inversão" ou de dinamização do ônus da prova, na audiência preliminar, daria ensejo a agravos retido e de instrumento, contribuindo assim com a morosidade procedimental e a eternização das lides, sem contar com a insegurança jurídica que isso proporcionaria.

Outro obstáculo processual de relevância diz respeito à incidência ou não da preclusão pro iudicato em face da decisão de "inversão" ou de dinamização em momento anterior à sentença. Não se objetiva defender se há ou não preclusão para o juiz, até porque não resta dúvida que tal decisum não é devido antes da sentença, mas demonstrar que ambas as posições (incidência e não incidência da preclusão) corroboram a tese ora propugnada quanto ao momento da dinamização do ônus da prova. Não obstante, não é demais afirmar que não incidiria tal preclusão por se tratar de questão de ordem pública.

Para aqueles que defendem a incidência da preclusão pro iudicato, caso o Estadojuiz concluísse, após a instrução processual, que o ônus da prova "invertido" ou dinamizado na audiência preliminar, na realidade, acabou gerando à parte onerada uma prova diabólica reversa, não se poderia mais alterar a distribuição do ônus da prova, estando o processo eivado de nulidade, sanável apenas na esfera recursal e, dessa forma, fadado à demora excessiva e, em efeito, a uma tutela jurisdicional injusta. 
Para aqueles que defendem a não incidência da preclusão pro iudicato, caso o Estado-juiz concluísse, em qualquer momento anterior ao da sentença, i.e., logo após o despacho saneador, durante ou após a instrução processual, que havia se equivocado, poderia dinamizar novamente a distribuição do ônus da prova, sem limites quantitativos, eternizando a lide e gerando uma insegurança jurídica flagrante e sem precedentes. ${ }^{391}$

Insta registrar, quanto ao tema da preclusão, que não há que se confundir nessa discussão, a incidência da preclusão temporal ou consumativa para as partes quanto à produção de prova, matéria essa já pacificada na doutrina e jurisprudência. ${ }^{392}$

Sob outro enfoque, mas com o mesmo objetivo de sustentar a impossibilidade de aplicação da teoria da dinamização do ônus da prova em momento diverso ao da sentença, insta estabelecer o raciocínio a seguir.

O dogma do ônus da prova, desde sua origem, expressa uma regra de julgamento, ou seja, uma regra que permite ao juiz, diante de incertezas dos fatos essenciais alegados na demanda, proferir um julgamento definitivo, evitando assim o non liquet. ${ }^{393}$ Essa regra de julgamento é intrínseca ao dogma do ônus da prova. Não há falar em ônus da prova, sem essa consequência, sem essa sanção de natureza processual-jurídica.

\footnotetext{
${ }^{391}$ Esse modelo de distribuição do ônus da prova que permite ao juiz dinamizar indeterminadas vezes, no mesmo processo, o ônus da prova, antes da sentença, não tem precedentes nos principais ordenamentos jurídicos estrangeiros: nem no direito americano e inglês - common law, nem no direito alemão, nem nos países europeus e da América Latina da família civil law. Cf. KOKOTT, The burden of proof..., 1998, p. 02236.

392 Posição pacífica na doutrina e jurisprudência. Por todos, DINAMARCO, Instituições..., 2009, v. 2, p. 565 569; Ibid., v. 3, p. 578-579. Ainda STJ. $4^{\text {a }}$ Turma. AgRg no Ag 967393/DF (2007/0237212-0). Rel. Min. Luis Felipe Salomão. Julgado em 02/09/2010. Publicado DJe em 10/09/2010; STJ. $3^{\text {a }}$ Turma. REsp 329034/MG (2001/0071265-9). Rel. Min. Humberto Gomes de Barros. Julgado em 14/02/2006. Publicado DJe em 20/02/2006; TJSP. 22 a Câmara de Direito Privado. Ap. 991090931654 (7355645700). Rel. Des. Roberto Bedaque. Julgado em 24/08/2010. Publicado em 27/08/2010; TJSP. $22^{\text {a }}$ Câmara de Direito Privado. Ag. Inst. 990101648741. Rel. Des. Roberto Bedaque. Julgado em 26/07/2010. Publicado em 28/07/2010; TJSP. 22a Câmara de Direito Privado. Ap. 991090653417 (7323809400). Rel. Des. Roberto Bedaque. Julgado em 09/06/2010. Publicado em 21/06/2010.

${ }^{393}$ VERDE, L' onere della prova..., 1974, p. 27, descreve, em instigante afirmativa, que a função da regra de juízo não deveria ser a de impedir o juiz de pronunciar uma sentença de non liquet, mas deveria fundar-se naquela que poderíamos definir como consequência de uma escolha de civilidade, já que se proíbe ao juiz de dar por existentes fatos que não lhe foi ofertada prova plena e convincente. (tradução nossa).
} 
Na hipótese de se retirar essa sanção do dogma do ônus da prova, a regra de julgamento se desfaz e, consequentemente, o próprio fenômeno do ônus da prova.

Por outro lado, para que o juiz saiba a quem aplicar a regra de julgamento, ou seja, qual das partes deve sofrer a dita sanção, no caso de omissão da respectiva parte, o legislador estabeleceu em seu bojo uma regra de conduta.

Na essência, a regra de conduta tem por função principal fixar a quem o magistrado imputará a regra de julgamento, ou seja, a quem aplicará uma sanção processual destinada a coibir a inércia no âmbito da produção da prova, e não fixar os fatos que cada parte deve provar. Em efeito, sua função principal é fixar a quem se aplica a regra de julgamento diante da omissão probatória.

Pode-se considerar, sem incongruências teóricas, que a função secundária, de natureza programática, da regra de conduta é de fixar abstrata e genericamente o thema probandum (fatos constitutivos, impeditivos, modificativos, extintivos) e quem deve prová-los (autor e requerido). Importante ressaltar que em nosso sistema processual civil vige o princípio da comunhão das provas e da liberdade probatória. Afinal, tanto o autor quanto o requerido podem produzir provas válidas e eficazes contra si. $\mathrm{Na}$ origem, o dogma do ônus da prova não continha essa regra de conduta. Esta era vinculada à simples e pura alegação e respectivo interesse.

$\mathrm{O}$ artigo 333 e incisos do CPC estabelece, assim, também uma regra de conduta. Pela literalidade do disposto no referido dispositivo legal, não há qualquer sanção para o descumprimento dessa regra de conduta. A sanção faz parte da outra face da regra, a de julgamento.

Ao mesmo tempo, indiscutível que o referido artigo trata do dogma do ônus da prova. É algo tão inerente ao dogma do ônus da prova que legislador nem consignou a respectiva sanção de forma expressa.

Se o autor não provar os fatos constitutivos de seu direito, a demanda será julgada improcedente, por ausência de prova e não porque o juiz considerou verdadeiros os fatos 
alegados pela parte contrária. Insta realçar que a sentença baseada na regra de juízo, apesar de transitar em julgado, não contém conteúdo normativo. ${ }^{394}$

Tem-se, dessa forma, a convicção que a regra de conduta e a regra de julgamento são faces do mesmo fenômeno: o dogma do ônus da prova. ${ }^{395}$ Em efeito, essas duas regras devem observar os ditames do dogma a que fazem parte. Um deles é que sua aplicação se dará na sentença, momento no qual a regra de julgamento - de caráter imperativo, impositivo - tem de ser aplicada pelo Magistrado. Trata-se, portanto, de uma obrigação, sob pena de negativa de jurisdição.

Como postulado deste dogma, não há como sustentar, sob o argumento de priorizar, enfatizar, valorizar a regra de conduta, permitir ao juiz que dinamize o ônus da prova antes da sentença. Isso quebraria as diretrizes dogmáticas do ônus da prova. O juiz só pode fixar o ônus da prova, na acepção de regra de conduta, indicando qual parte deve produzir essa ou aquela prova, ou em abstrato, antes de iniciada a demanda ou no ato sentencial.

Durante o procedimento ele estaria fazendo uma avaliação antecipada da prova e, consequentemente dos fatos, em momento inapropriado, i.e., antes da sentença. Repito, estaria quebrado o dogma do ônus da prova, pois haveria uma antecipação da regra de juízo para um momento anterior à sentença, com o objetivo não de julgar, mas de valorar parcialmente a prova até então produzida.

Agindo dessa forma, estaria o magistrado repartindo o ônus da prova baseado em razões de verossimilhança do caso concreto, com base em um contexto probatório incompleto, formando um convencimento ou anterior ou paralelo à repartição do referido ônus, tornando impossível saber onde termina o seu convencimento e onde começa a repartição do ônus da prova. ${ }^{396}$

\footnotetext{
${ }^{394}$ Substancialmente nesse sentido VERDE, L' onere della prova..., 1974, p. 57. Afirma o autor que um dos pontos centrais de sua tese, sobre o ônus da prova no processo civil, consiste em "negare autonomo contenuto normativo alla regola di giudizio fondata sull’onere della prova.”.

${ }^{395}$ Mc Naughton configura o ônus da prova subjetivo como função derivada do ônus objetivo da prova. In Burden of production of evidence: a function of a burden of persuasion, Harvard Law Rev., 1954-55 (68), p. 481 ss. Apud VERDE, Ibid., p. 52, nota 81.

${ }^{396}$ PATTI, Prove..., 1987, p. 173, afirma que a regra sobre o ônus da prova não pode ser modificada com base em verossimilhança de um fato.
} 
Não há possibilidade do juiz, mentalmente, intelectivamente, distribuir a regra de conduta, sem pensar em quais provas estão ausentes, em quais fatos a prova está pendente, insuficiente. Neste raciocínio, diante de tal avaliação, haveria duas consequências para a não realização da prova. A primeira seria sua redistribuição (no meio do procedimento) e a segunda a aplicação da regra de julgamento no final (na sentença). Caso isso fosse permitido, o legislador estaria instituindo, prima facie, uma perigosa regra que levaria o juiz, em inúmeras situações concretas, a violar o imprescindível princípio da imparcialidade.

Além disso, se fosse possível a aplicação desta teoria ou mesmo de qualquer espécie de modificação do ônus da prova na audiência preliminar, ou seja, antes da produção de qualquer prova nos autos, estaria o magistrado correndo o risco de violar o preceito da proibição da antecipação do resultado da prova, ${ }^{397}$ principalmente quando redistribuísse o ônus da prova parcialmente. Na essência, mas, acrescido desta outra vertente, volta-se ao problema mencionado acima, relativo ao risco de se violar o princípio da imparcialidade ao realizar a valoração prévia dos fatos e de se saber qual é o ponto final do convencimento do magistrado e o ponto inicial da repartição do ônus da prova.

Por fim vale ressaltar, ad ilustrandum, que somente seria possível seccionar o dogma do ônus da prova, conferindo primazia ao ônus subjetivo da prova e, assim, permitindo uma dinamização do ônus da prova antes da sentença, se a regra do ônus da prova tratasse somente da questão de saber de qual parte o juiz deve esperar ou exigir uma atividade probatória, não se podendo imputar qualquer sanção ao seu descumprimento, ou seja, não se podendo aplicar a regra de julgamento. A questão de saber qual parte deve suportar a consequência desfavorável da falta de prova de uma afirmação de fato importante e discutida, é seara da regra de julgamento, portanto, ônus objetivo da prova. ${ }^{398}$

\footnotetext{
${ }^{397}$ O preceito da proibição da antecipação do resultado da prova estabelece que o valor, a utilidade e, em certos limites, a própria relevância de um meio de prova não podem ser valorados antes que a prova tenha sido produzida nos autos. Afirma TROCKER, Processo civile e costituzione..., 1974, p. 520-522, que esse princípio objetiva, acima de tudo, estabelecer precisos limites à discricionariedade do poder judicial de obtenção e produção dos meios probatórios. E, nesse sentido, representa um válido estratagema para evitar que o princípio da livre valoração e do livre convencimento saia de seu âmbito natural, que é aquele da prova efetivamente produzida.

${ }^{398}$ Cf. ROSENBERG, La carga..., 2002, p. 122.
} 
Diante disto resta impossível sustentar com coerência científico-jurídica, em nome de uma maior ênfase ao ônus da prova subjetivo, a possibilidade de redistribuição do ônus da prova em momento diverso ao da sentença.

\subsubsection{Limites na aplicação da dinamização pelo Estado-juiz}

Inicialmente importa ressaltar que a constituição dos requisitos que permitem a aplicação da teoria da dinamização do ônus da prova tem ainda por função coibir o livre arbítrio do magistrado nesta seara, uma vez que vinculam sua atividade jurisdicional, eliminando o elemento consistente na mera vontade do julgador.

Entretanto, subsiste a necessidade de identificar e estabelecer mecanismos que visem impedir o cometimento de arbitrariedades e nulidades insanáveis, quando da aplicação da teoria da dinamização do ônus da prova pelo magistrado. Em efeito, torna-se absolutamente adequado a este propósito a instituição de limites para a realização do mencionado ato jurisdicional. Tais limites, indubitavelmente, dizem respeito exclusivamente à atividade do magistrado, pois é o único responsável pela aplicação da regra de julgamento e da teoria sob menção.

Ao identificar e estabelecer os requisitos para a aplicação da teoria da dinamização do ônus da prova, conforme objeto de seção anterior, foram fixados, a contrario sensu, os limites de sua aplicabilidade. Em efeito, o magistrado, diante do caso concreto, não poderá aplicar a teoria se ao menos um dos requisitos evidenciados não estiver presente, o que conduziria, ao mesmo tempo, na prática de livre arbítrio e de inaceitável arbitrariedade.

Desta forma, a título de exemplo, se o juiz não identificar no processo que a parte não onerada apresenta, efetivamente, maior facilidade na produção da prova, não poderá aplicar a teoria sob enfoque, sob pena de causar nulidade processual insanável com fulcro em preceitos de ordem processual e constitucional.

É possível, diante disso, estabelecer como limites ou requisitos negativos na aplicação da teoria da dinamização do ônus da prova a inexistência da maior facilidade na 
produção da prova por uma das partes, a existência de reais condições fáticas da prova ser produzida, principalmente pela parte inicialmente onerada, pois a prova pode materialmente não existir mais, ${ }^{399}$ a existência de igualdade econômico-financeira, a existência de igualdade técnica, a inexistência de prova complexa.

Além dos limites que se contrapõem diretamente aos respectivos requisitos de aplicabilidade, como as faces do binômio legal-ilegal, proibido-permitido, justo-injusto, outro limite à aplicação da teoria da dinamização se evidencia: a existência da denominada probatio diabolica reversa.

Contudo, diferentemente dos demais limites, que trabalham com polos que se repelem, positivo e negativo, i.e., o requisito seria o positivo à aplicação da teoria e o correspondente limite o negativo, o limite pertinente à existência da probatio diabolica reversa, na essência, não apresenta necessariamente essa característica.

A prova diabólica reversa deriva, na maioria das vezes, da prova diabólica. Entretanto, adverte-se que nem toda prova diabólica para uma parte consistirá em prova diabólica reversa para a outra parte. Quando isso ocorrer, a característica acima estará presente, pois se a prova diabólica é um requisito para aplicação da teoria, a prova diabólica inversa é um impedimento, um limite a sua aplicação.

Diversamente, quando as duas se fizerem presentes no caso concreto, tanto a prova diabólica para o autor quanto a prova diabólica inversa para o requerido, ambas se anularão, uma vez que o magistrado estará impedido de aplicar a teoria da dinamização em face das duas partes, i.e., sob a ótica do magistrado ambas serão limite - negativo, e não requisito de aplicação - positivo.

A prova diabólica reversa pode ainda derivar de qualquer outro tipo de requisito que permite a aplicação da teoria da dinamização do ônus da prova, desde que para a outra parte seja absolutamente impossível a sua produção.

\footnotetext{
399 Deve-se considerar que a inexistência material da prova não se deu por ato culposo ou doloso daquela parte que a detinha e, assim, que tinha maior facilidade em sua produção.
} 
Quando o magistrado, diante do caso concreto, analisar se o requisito da maior facilidade da prova está presente para a parte não onerada, deverá ainda fazer outra análise de igual relevância. Deverá, obrigatoriamente, verificar se a aplicação da dinamização do ônus da prova, não causará à parte doravante onerada com a produção da prova e as consequências pela respectiva inércia ou insuficiência probatória, um obstáculo invencível, intransponível.

O magistrado, sob o argumento de equilibrar a desigualdade probatória evidenciada nos autos, não pode, ao aplicar a teoria em tela, simplesmente modificar o lado pelo qual pendia a desigualdade. Em outras palavras, não pode retirar os pesos em excesso de um prato da balança e colocá-los no outro prato. Estaria apenas mudando o polo da desigualdade e, quiçá, sua intensidade. Além disso, com essa atitude, não pode absolutamente, criar uma verdadeira probatio diabolica reversa.

Essa hipótese, caso concretizada pelo magistrado, é sinônimo, ad abundantiam, de nulidade insanável e, até mesmo, indício de arbitrariedade de seu prolator, uma vez que foram identificados e estipulados limites objetivos à aplicação da teoria da dinamização do ônus da prova.

\subsection{Prova diabólica reversa}

Como foi visto em seção específica, ${ }^{400}$ a existência de circunstâncias que configuram a probatio diabolica consiste em um dos requisitos que permitem a aplicação da teoria da dinamização do ônus da prova. ${ }^{401}$

Contudo, a outra face dessa mesma moeda, ou seja, a probatio diabolica reversa, é causa de impedimento à utilização da teoria da dinamização, configurando um verdadeiro limite a sua aplicação. Esse limite, pertinente à criação de uma verdadeira probatio diabolica reversa, por decisão do Estado-juiz, merece uma análise acurada. Como

\footnotetext{
${ }^{400}$ Cf. seção 3.2.2.1.6.

${ }^{401}$ KNIJNIK, As (perigosíssimas) doutrinas..., 2006, p. 942-951, sustenta que a doutrina do ônus dinâmico da prova é um dos instrumentos eficazes de superação da probatio diabolica.
} 
afirmado, o Estado-juiz, ao aplicar a teoria da dinamização do ônus da prova, tem a obrigação de averiguar se no caso concreto, ao dinamizar esse ônus, não estará tornando impossível a sua produção para a outra parte que, originariamente, não era onerada.

Desta forma, se a produção de determinada prova a cargo da parte autora é diabólica, não pode a mesma guardar essa característica e circunstância em relação à parte ex-adversa, ou seja, a produção da respectiva prova tem que ser possível para a parte requerida. Se a prova, em relação à parte requerida, também se caracterizar como diabólica, contendo um obstáculo instransponível a sua produção em juízo, não poderá o Estado-juiz aplicar a teoria da dinamização do ônus da prova.

Diversa é a hipótese em que a prova é diabólica para a parte autora, inicialmente onerada, mas que se configura prova difícil para a parte ex-adversa. Nesta hipótese não há qualquer limite à aplicação da teoria da dinamização do ônus da prova.

Insta ratificar que prova diabólica, bem como a prova diabólica reversa, não se confundem com prova difícil, não sendo, portanto, expressões sinônimas. Ad abundantiam, prova difícil é aquela que apresenta um ou mais obstáculos para que determinada parte a produza nos autos, sendo esses obstáculos fática e juridicamente transponíveis e a prova possível de ser produzida; prova diabólica e a reversa transcendem o nível da dificuldade, chegando ao grau máximo pertinente à impossibilidade, sendo aquela que apresenta um ou mais obstáculos intransponíveis pela parte que tem interesse em produzi-la ou está onerada com sua produção. ${ }^{402}$

Recorrendo mais uma vez ao método exemplificativo, insta retornar ao exemplo anteriormente trabalhado quando foi analisada a prova diabólica. Caso a parte autora, inicialmente onerada pelas regras do artigo 333, inciso I do CPC, tenha interesse em produzir em juízo uma prova documental essencial a sua alegação, mas essa prova esteja em custódia em um banco, em um cofre, em nome da parte requerida, esta prova será considerada diabólica para a parte autora. Será considerada prova diabólica reversa, para a parte requerida, na hipótese, v.g., do respectivo banco ter sido alvo de um devastador incêndio, tendo todo o seu interior se tornado cinzas.

\footnotetext{
${ }^{402}$ Cf. seção 3.2.2.1.6, notas 320 e 321.
} 


\subsubsection{Poder-dever, dinamização, fundamentação e sentença}

Ao aplicar a dinamização do ônus da prova, após verificar a presença de ao menos um dos requisitos de aplicabilidade da teoria no caso concreto, o magistrado não o faz por livre arbítrio, mas por uma imposição e observância aos ditames constitucionais e sistemáticos. Insustentável, assim, a afirmativa de que o magistrado, em tais hipóteses, agiria movido pela mera discricionariedade.

Como foi visto anteriormente, o magistrado somente poderá aplicar a teoria da dinamização do ônus da prova diante da presença de ao menos um dos requisitos objetivos. Insta ressaltar, diante deste enfoque, que os fundamentos de aplicabilidade da teoria, que serão objeto de análise nas seções seguintes, funcionam como fatores limitadores e controladores da atividade judicial.

Em efeito, essa atividade do magistrado consiste em um verdadeiro poder-dever e não mera faculdade, diante das garantias e direitos fundamentais que envolvem a matéria posta sob análise ao órgão julgador.

Os críticos, ainda presos à concepção liberal-privatista de processo e de seu princípio exclusivamente dispositivo, temem que a teoria da dinamização configure um instrumento que concede excessivo poder nas mãos do magistrado. Contudo, a partir do momento que foram estabelecidos critérios de ordem objetiva que afastam o livre arbítrio e que controlam as arbitrariedades, i.e., requisitos e limites em sua aplicação, desaparece a razão de ser desse temor. Ademais, o senso de responsabilidade com as matérias de ordem constitucional sempre foram uma marca da magistratura brasileira. ${ }^{403}$

\footnotetext{
${ }^{403}$ MARINONI, Formação da convicção e inversão do ônus da prova..., 2009, p. 263, afirma, ao discorrer sobre o tema, que não se deve pretender limitar o poder do juiz, mas sim controlá-lo, e isso não pode ser feito mediante uma previsão legal da conduta judicial, como se a lei pudesse dizer o que o juiz deve fazer para prestar a adequada tutela jurisdicional diante de todas as situações concretas. Como as situações de direito material são várias, deve-se procurar a justiça do caso concreto, o que repele as teses de que a lei poderia controlar o poder do juiz. Esse controle, atualmente, somente pode ser obtido mediante a imposição de uma rígida justificativa racional das decisões, que podem ser auxiliadas por regras como as da proporcionalidade e suas sub-regras.
} 
Pode-se assim, firmar premissa fundamental para essa teoria, no sentido de que o juiz tem o poder-dever de aplicar a dinamização do ônus da prova, não lhe sendo possível, diante do caso concreto e preenchidos os requisitos objetivos da aplicabilidade, optar pela sua não aplicação e pela adoção do critério tradicional de distribuição do ônus da prova, gerando, em consequência, efetivos prejuízos a uma das partes e violando as regras constitucionais e sistêmicas que fundam sua aplicação.

Diante desse poder-dever, o magistrado, ao evidenciar no caso concreto, ser hipótese de aplicação da teoria da dinamização dos ônus probatórios deverá fazê-lo no ato sentencial, pois somente neste momento será possível realizar uma avaliação definitiva do conjunto probatório produzido, averiguando se as partes mantiveram-se inertes quanto à produção probatória, se a parte onerada produziu prova suficiente de suas alegações, se a parte contrária produziu prova suficiente de suas alegações visando contrapor as da parte autora e, por último, se é hipótese de utilizar a regra de julgamento diante da existência de incerteza quanto aos fatos essenciais da demanda.

Estando seguro quanto ao cabimento da aplicação da regra de julgamento, deverá em seguida, sempre diante do caso concreto, averiguar ainda se deve aplicar a teoria da dinamização do ônus da prova, imputando o ônus da prova e as consequências de sua ineficiência probatória, àquela parte que inicialmente não estava onerada, de forma integral, em relação a todos os fatos essenciais da demanda ou, parcialmente, quanto a determinados fatos essenciais.

Na sentença, por intermédio de um tópico específico, deverá de forma detalhada especificar os motivos e os requisitos que o levaram a aplicar a teoria da dinamização do ônus da prova naquela hipótese concreta.

Vale ressaltar que, na realidade, quando o magistrado exercitou de forma plena seu dever de informação às partes, preferencialmente na fase do saneamento, conforme anteriormente explicitado neste trabalho, ele já vislumbrava a possibilidade futura de aplicação da teoria da dinamização do ônus da prova na eventualidade das partes não conseguirem sanar todas as incertezas fáticas após a ampla instrução probatória. 
Quanto à necessidade de motivação, o artigo 93, inciso IX da CR/88 elimina qualquer espécie de questionamento a respeito. A explanação dos motivos que foram decisivos na formação do convencimento do magistrado no sentido da aplicação da teoria da dinamização do onus probandi é condição de validade do próprio ato, ensejando sua ausência ou sua insuficiência em nulidade insanável passível de reconhecimento pelo órgão ad quem em sede recursal.

A fundamentação do juiz não pode consistir em expressões vagas, dúbias, quanto o mais vazias de conteúdo sobre os motivos que formaram seu convencimento. Ao revés, deve ir ao ponto chave que o convenceu a aplicar a teoria sob enfoque, evidenciando qual ou quais os requisitos de aplicabilidade se baseou para tal, cotejando os fatos e argumentos apresentados pelas partes e os fatos e circunstâncias que restaram provados e/ou os que restaram incertos. Deve, ainda, se reportar ao ato processual no qual exerceu de forma plena o mencionado dever de informação às partes.

\subsubsection{Consequências da aplicação da dinamização no ordenamento jurídico}

A aplicação da teoria da dinamização dos ônus probatórios, diante da estrutura sistêmica do nosso ordenamento jurídico, bem como do nosso direito processual civil, apresenta-se extremamente vantajosa, em cotejo com a distribuição rígida do $\mathrm{CPC}^{404}$

É possível apontar as seguintes consequências favoráveis a sua aceitação e aplicação pelo sistema processual civil pátrio.

Primeiramente, a eliminação da técnica da inversão do ônus da prova vigente em nosso sistema processual civil, pois só há falar-se em inversão do ônus da prova em um sistema que adotada unicamente a técnica rígida de distribuição. Ademais, as hipóteses permissivas de "inversão" do ônus da prova, positivadas em nosso sistema jurídico, são hipóteses ensejadoras de aplicação da dinamização dos ônus probatórios. A teoria da

\footnotetext{
404 Afinal, "bien sabe el Derecho Procesal que lo único permanente son los cambios. La realidad es más fuerte y rica que las teorías que quieren apresarla y darle explicación.”. Pensamento de Heráclito de Efeso, filósofo grego, ano 500 a.C.
} 
dinamização soluciona ainda o problema relativo ao equívoco terminológico instituído pela expressão contida no artigo $6^{\circ}$, inciso VIII do CDC.

A teoria da dinamização do onus probandi corrobora o tradicional entendimento doutrinário e jurisprudencial a respeito da dicotomia relativa ao ônus da prova objetivo e subjetivo, no sentido de reconhecer a maior relevância do primeiro na estrutura do fenômeno. Quanto a esse particular, na essência, a dinamização em nada altera os contornos teóricos dessa classificação: o ônus objetivo continua sendo regra de julgamento e o ônus subjetivo continua sendo regra de procedimento das partes. Tem ainda a virtude de esclarecer e delimitar com precisão, as funções teóricas e práticas relativas ao ônus da prova subjetivo no interior do fenômeno do ônus da prova.

Uma terceira consequência, de cunho muito mais sociocultural do que técnicojurídico, contudo não menos importante, refere-se à mudança de mentalidade do jurisdicionado quanto ao uso do processo.

É assente no meio jurídico que muitas vezes o processo é utilizado com finalidades absolutamente estranhas a sua razão de ser, v.g., como instrumento de coação da parte economicamente mais forte, em detrimento da outra parte mais fraca; como instrumento de efetivação consciente de uma conduta civilmente ilícita, mediante manobras processuais estrategicamente realizadas, visando à obtenção de lucro, mesmo sabendo que, ao final, deverá arcar com um ressarcimento o qual, diante da relação custo-benefício, é compensatória; ${ }^{405}$ como instrumento de criação de um fato político, muitas vezes de tão forte poder persuasivo que consegue modificar um pleito eleitoral, principalmente em âmbito municipal; como instrumento de promoção pessoal de advogados, promotores, defensores públicos, procuradores, em detrimento do próprio ente Estatal; como instrumento de extorsão velada, mormente em demandas de natureza trabalhista ${ }^{406}$ e em

\footnotetext{
405 Exemplo clássico é o das construtoras que, através da obtenção de liminares, sob a difusa alegação de existência de periculum in mora, obtém autorizações para construções, flagrantemente contrárias às disposições legais municipais, inseridas principalmente nos planos diretores urbanos, cientes que ao final, o provável ressarcimento aos cofres públicos municipais, quando e se efetivados, compensará a citada prática ilícita, diante dos lucros obtidos com a comercialização de imóveis.

${ }^{406}$ No direito do trabalho, é fato corrente na sociedade brasileira, de norte a sul, leste a oeste, apesar de não cientificamente comprovado, ante a ausência de estudo sério nesse sentido, que o empregado sempre tem razão e que a Justiça Trabalhista sempre pende a sua balança para o lado deste, na maioria das vezes, vítima de patrões exploradores. Diante desse cenário, o processo é utilizado por alguns, como forma de extorsão velada, "obrigando" os empregadores a um acordo injusto e indesejado.
} 
demandas baseadas no direito consumerista, diante das regras positivadas de "inversão" do ônus da prova. ${ }^{407}$

A aplicação da teoria da dinamização em nosso ordenamento jurídico, principalmente no subsistema do direito processual civil irá contribuir com essa mudança de mentalidade a partir do momento que todo jurisdicionado, todo advogado, todo demandante, tiver a ciência que poderá, no caso concreto, pesar sobre si as consequências da não produção de provas de determinado fato, cuja produção seria essencial para o descobrimento da verdade e que, muitas vezes, melhor seria que não ocorresse.

Em outras palavras, reduzir-se-á visivelmente a interposição das conhecidas e indesejadas demandas temerárias, a partir do momento que ao sujeito processual imbuído da má-fé, poderia ser facultada a produção de provas, que inclusive sabe impossível, pois inexistentes os fatos alegados, arcando com esse ônus processual.

Não restam dúvidas que a distribuição rígida, prévia, abstrata dos ônus probatórios, facilita essas manobras senão fraudulentas, ao menos eivadas de má-fé e marcadas por um proceder flagrantemente antiético. Como se não bastasse, essa técnica de distribuição rígida dificulta a produção de prova de quem, no caso concreto, tem menos condições de fazê-lo, como foi exaustivamente verificado. ${ }^{408}$

Por outro lado e sob um outro enfoque, o autor da demanda, vítima da violação de seu direito por outrem, que, aliás, resiste em restituí-lo ao status quo ante ou, em sua impossibilidade, compensá-lo pela violação, em determinados casos concretos, diante de situações específicas, porém não raras, além desse dissabor primeiro, terá que constituir advogado, cujos honorários dificilmente lhe serão ressarcidos, dispor das custas e despesas processuais iniciais, ou seja, tendo um gasto concreto para ver seu direito reposto, e que somente serão devolvidas ao final - evento futuro e incerto - e, ainda por cima, diante da distribuição rígida dos ônus probatórios, ter o trabalho maior e, às vezes, muito mais difícil

\footnotetext{
${ }^{407}$ Nas demandas baseadas no direito do consumidor, a técnica da "inversão" do ônus da prova é utilizada de forma ainda mais vil, pleiteando-se indenizações milionárias e/ou sem qualquer lastro probatório, com respaldo na proteção da inexigibilidade da produção de provas.

${ }^{408}$ Quantas pessoas humildes, sem condições de constituir um advogado, deixam seu direito material ser violado, às vezes direito inerente a sua própria personalidade, por não terem condições financeiras, condições culturais, sequer de obter a prova da violação de seu direito, exigida pelo artigo 333, inciso I do CPC.
} 
que o próprio demandado, causador de todo problema, de provar o fato constitutivo de seu direito. A distribuição dinâmica vem, caso a caso, sanar com essa desigualdade.

A teoria da dinamização do ônus da prova é, indubitavelmente, na esfera prática, um instrumento processual efetivo no combate ao uso indevido do processo e da própria jurisdição. Em virtude disso, contribui de forma enfática na resolução do congestionamento das atividades do Poder Judiciário, a partir do momento que demandas desnecessárias e temerárias deixariam de ser levadas àquele Poder.

Outra consequência positiva da aplicação da presente teoria em nosso ordenamento jurídico é, ainda que de forma indireta, a de contribuir para a diminuição da morosidade processual, pois é um mecanismo jurídico que contribui efetivamente com a celeridade processual, na medida em que evita atrasos indesejáveis.

Quando o magistrado, ao se preparar para o ato sentencial, verificar que ainda subsistem incertezas quanto a fatos essenciais para o deslinde da demanda, poderá adotar dois caminhos: ou aplica a regra de juízo e julga com base em incertezas ou utiliza o poder instrutório do juiz naquelas hipóteses em que não configurar parcialidade do juízo. Este último procedimento, caso adotado, obriga o julgador a re-abrir a instrução probatória e, consequentemente o contraditório, atrasando o procedimento e o proferimento da decisão definitiva. Em síntese, pelo atual sistema de distribuição rígida do ônus probandi, o juiz não tem outro caminho procedimental senão utilizar o poder instrutório ou aplicar a regra de julgamento pertinente ao ônus da prova.

$\mathrm{Na}$ verdade, ambas as soluções não são ideais. A primeira por estabelecer um julgamento de mérito baseado em incertezas, indesejável, portanto. A segunda por criar um incidente processual que, além de provocar atrasos, enseja um resultado incerto e que pode, por fim, levar a utilização da primeira regra.

A teoria da dinamização do ônus da prova dá uma contribuição efetiva em ambos os sentidos, pois, ao mesmo tempo em que contribui com a descoberta da verdade, evita a utilização desse poder instrutório e, assim, evita a ocorrência de incidentes processuais geradores de morosidade. Em outras palavras, colabora de forma efetiva para diminuir as hipóteses de aplicação de ambos os procedimentos acima delineados. 
Essa contribuição da teoria da dinamização se apresenta visível a partir do cumprimento, pelo magistrado, do dever de informação às partes de que, ao final, no momento da sentença, este poderá aplicar a dinamização do ônus da prova e usar a regra de julgamento, na hipótese de subsistirem incertezas fáticas.

A partir desse ato, as partes estarão plenamente cientes do risco de utilizarem expedientes de estratégia processual baseados na distribuição rígida do ônus da prova para descumprirem o dever de colaborar na descoberta da verdade, pois poderão ao final, ao ser aplicada a teoria da dinamização, colher as consequências dessa conduta deliberadamente omissa.

Na prática, após essa manifestação do magistrado, ambas as partes terão ciência do que devem provar para evitar a aplicação da regra de juízo e para lograr êxito em seus pleitos, com absoluto tempo hábil a fazê-lo. Doravante, o resultado da instrução probatória passa a ser responsabilidade de ambas as partes e não somente da parte inicialmente onerada, de acordo com a natureza dos fatos a ser provados (constitutivo, impeditivo, modificativo, extintivo). Na prática, a inércia dolosa daquela parte beneficiada pela regra fixa do ônus da prova desaparecerá, diante da já notificada possibilidade de dinamização do ônus da prova.

Em síntese, a teoria da dinamização dos ônus probatórios apresenta-se ainda como um eficiente instrumento processual, que potencializa e instrumentaliza a efetividade da tutela dos direitos materiais. 


\subsection{FUNDAMENTOS DA APLICABILIDADE DA DINAMIZAÇÃO}

Os fundamentos que servem de pilar à aplicabilidade da teoria da dinamização do ônus da prova, quer seja de lege lata ou mesmo de lege ferenda, consistem, ao mesmo tempo, em verdadeiras justificativas para sua criação, desenvolvimento e, obviamente, sua aplicação prática.

Maior destaque deve ser conferido aos fundamentos que justificam a aplicação da teoria sob enfoque de lege lata, ${ }^{409}$ uma vez que esta implica, prima facie, quer seja parcial $^{410}$ ou totalmente, superação do artigo 333 e incisos do CPC, diante de cada caso concreto, ou seja, da inaplicabilidade da regra geral e tradicional do ônus da prova.

Na verdade, não se trata de considerar inválida a disciplina tradicional, mas uma forma de aperfeiçoar e complementar o sistema processual civil, relativamente ao dogma do ônus da prova, por intermédio da doutrina, ao acolher a presente teoria ${ }^{411} \mathrm{e}$ da jurisprudência, ao aplicá-la reiteradamente.

Afinal, é de conhecimento geral e uma realidade em nosso país que a via legislativa não é a mais eficaz, na relação tempo e qualidade, nesse mister de proporcionar mudanças

\footnotetext{
${ }^{409}$ YARSHELL, Antecipação da prova..., 2009, p. 87 e 88, não obstante reconhecer e afirmar o mérito da teoria da dinamização do ônus da prova, uma vez que esta parte da premissa de que o encargo deve ser atribuído conforme a maior ou menor facilidade de acesso e de produção da prova e que da flexibilização desse encargo se deve cogitar se o ônus de uma das partes se revelar de tal forma excessivo que gere o risco de inviabilizar a produção da prova e, assim, de ferir as garantias do devido processo legal, da ação, do contraditório a da ampla defesa, é categórico quanto à impossibilidade de sua aplicação de lege lata, i.e., sem que haja autorização do legislador para tal. Todavia, afirma que a possibilidade de inversão do ônus da prova, por obra do juiz em dado caso concreto, pode até mesmo extrapolar as hipóteses expressamente previstas pela lei toda vez que constatado o peso excessivo que tal ônus representa, no confronto com a possibilidade de produção de prova pela parte adversária.

${ }^{410}$ Nesse sentido DALL'AGNOL JÚNIOR, Distribuição dinâmica..., 2001, p. 106, ao afirmar que o artigo 333 do CPC não pode ser examinado isoladamente (como poucos dispositivos legais o podem ser de resto), mas em conjunto com as demais regras e, sobretudo, considerados os princípios que informam o processo civil na sua feição atual, menos individualista e mais solidária.

${ }^{411}$ Nesse sentido KNIJNIK, As (perigosíssimas) doutrinas do "ônus dinâmico da prova”..., 2006, p. 947 e 950. Afirma o autor que é legítima a teoria da dinamização do ônus da prova perante o direito brasileiro, não havendo motivo para que a igualdade substancial entre os litigantes não se reflita no plano do ônus probatório. E complementa lecionando que a teoria da carga dinâmica combina-se com o fundamento normalmente adotado para atribuir ao juiz iniciativas probatórias que a rigor não se compadeceriam com a aplicação estática do art. 333 do CPC.
} 
nas leis processuais e procedimentais, as quais a sociedade e sua dinâmica já vislumbraram a efetiva necessidade, apesar de ser essa a função institucional desse Poder.

Em virtude dessa peculiar barreira, incumbe à academia do direito, através da doutrina jurídica e à jurisprudência de nossos tribunais, iniciarem esse processo de ajustamento teórico-prático entre o direito e a sociedade, respeitando a evolução e o dinamismo do mundo contemporâneo, sob pena de cair no ostracismo e gerar um irreversível déficit de legitimidade do sistema jurídico.

Nessa perspectiva, este capítulo visa analisar verticalmente esses fundamentos e justificativas de aplicabilidade da teoria em questão. Alguns desses fundamentos vem sendo expostos desde o início deste título, de forma gradual e sistêmica, em virtude de sua estreita ligação com os demais temas já trabalhados.

Os fundamentos em menção foram divididos, visando conferir uma sequência lógico-jurídica ao raciocínio em desenvolvimento, em constitucionais e sistêmicos. $A d$ abundantiam, o que se propõe é demonstrar a possibilidade de aplicação da teoria da dinamização do onus probandi, mesmo sem estar positivada, diante da existência de fundamentos de ordem sistêmico-principiológicos, bem como de fundamentos de ordem constitucional, existentes no bojo do nosso sistema jurídico.

Foi afirmado, anteriormente, que as regras rígidas ora vigentes que disciplinam a distribuição do ônus da prova não são suficientes e eficazes para toda e qualquer hipótese que ocorre concretamente. $\mathrm{O}$ atual sistema rígido e inflexível de distribuição do ônus da prova, vigente em nosso sistema processual civil, tem provocado um distanciamento abismático entre o direito processual e o direito material, dirigindo-se na contramão das tendências das ordenações processuais contemporâneas, na contramão do maior valor do ordenamento jurídico, a justiça e, ainda, contribuindo para que as finalidades do processo e da própria jurisdição não sejam efetivamente atingidas, o que, via de consequência, provoca um déficit de legitimidade, sem falar de credibilidade, no nosso sistema processual civil. $^{412}$

${ }^{412}$ CANOTILHO, Estudos..., 2004, p. 174-175, enfatiza que o legislador processual não pode estabelecer regras conducentes a uma injusta distribuição do ônus da prova, pois a medida justa da distribuição do ônus 
As premissas que serão apresentadas demonstrarão de forma cabal a efetiva possibilidade de aplicação da teoria da dinamização do ônus da prova, consistindo, assim, em verdadeira evolução teórica e prática, relativamente a essas regras rígidas e inflexíveis de distribuição do onus probandi. Aliás, quem convive com essas regras, cotidianamente, já observou essa necessidade de superação e evolução. Contudo, esbarrou na literalidade dessas regras ultrapassadas, dissonantes da realidade fática e da própria realidade processual, ante seu caráter inflexível.

A evolução da concepção de um processo civil eminentemente de cunho privadoindividualista, para um processo civil de natureza mista, ou seja, publicizado, indubitavelmente também contribuiu para a proposição da evolução das regras pertinentes à distribuição do ônus da prova. Essa evolução de concepção, comparável a uma verdadeira mudança de paradigma, se efetivamente não o é, na realidade, tem proporcionado ao jurista pátrio uma rica fonte de novos objetos de pesquisa, ensejando grandes mudanças e novas teorias a respeito de determinados institutos e fenômenos de ordem processual civil.

Essa evolução percorre ainda, necessariamente, o caminho da mitigação do princípio dispositivo em âmbito do processo civil, considerado um quase-dogma, sendo um verdadeiro expoente da concepção liberal-individualista do processo civil do século XIX e XX. Apesar disso, sua importância no subsistema acima citado é incontestável, não podendo ser desprezada. Com a mesma força e intensidade adjacentes de toda evolução, outros princípios e ideais se revitalizam como o da instrumentalidade processual, o ideal solidarista e a idéia de cooperação processual.

Como se não bastasse, nesse movimento evolutivo que o processo civil está vivenciando em ritmo acelerado, o dogma maior do sistema jurídico, seu valor supremo, a justiça, reaviva-se, buscando sua concretude, sua visibilidade fática, sua humanização, em oposição ao sagrado, inatingível, porque não dizer, em oposição ao adorado formalismojurídico, no princípio constitucionalizado da igualdade.

da prova é fundamental para a garantia de um direito e, assim, impõem-se soluções probatórias não aniquiladoras da própria concretização de diretos, liberdades e garantias. 
Confirmando a necessidade dessa evolução e, ao mesmo tempo, justificando a aplicação da dinamização do ônus da prova, apresentam-se direitos de natureza constitucional, consistentes em assentadas garantias fundamentais constitucionais, que, todavia, almejam maior efetividade no nosso sistema jurídico.

Em efeito, os fundamentos constitucionais e os fundamentos sistêmicos a seguir analisados, formam o arcabouço teórico-jurídico do qual se abstrai, indubitavelmente, a permissão técnica-legal para a aplicação da distribuição dinâmica do ônus da prova em nosso sistema processual civil, independentemente de qualquer mudança em nossa legislação, precisamente do teor do artigo 333, incisos I e II do CPC. ${ }^{413}$

${ }^{413}$ Importante mencionar aqui a existência do Projeto de Lei do Senado no $166 / 2010$, cujo objetivo é reformar o Código de Processo Civil Brasileiro que, caso aprovado sem emendas, promoverá a inserção da teoria da dinamização do ônus da prova no direito positivo pátrio. Cf. Título IV, seção 4.4. 


\subsubsection{PRINCÍPIOS VERSUS REGRAS JURÍDICAS}

Com o propósito de eliminar afirmativas e argumentos demasiadamente abstratos e buscando atingir os objetivos propostos de forma precisa e convincente, foi priorizado tratar o assunto à epígrafe estritamente nos domínios de um único sistema científico, o jurídico. Acredita-se que esse reducionismo didático é absolutamente necessário para uma compreensão perfeita do tema central sob enfoque, ou seja, que a teoria da dinamização do ônus da prova apresenta fundamentos legítimos a sua aplicação de lege lata.

Ainda nesse caminho intelectivo e já adentrando na discussão proposta, não se evidencia conveniente, no âmbito deste trabalho, o aprofundamento quanto às classificações dos tipos de normas jurídicas. Aliás, é um campo vastíssimo e de elevada complexidade, ainda mais considerando que a doutrina específica adota critérios diferenciados, na maioria tópicos, não se chegando a um conjunto uniforme. ${ }^{414}$

Diante disso, é importante ratificar, não obstante a sua obviedade que, por excelência, o sistema jurídico é constituído por normas jurídicas e que as únicas espécies normativas que efetivamente interessam, doravante, são os princípios e as regras. E, dentre essas normas, serão cotejadas especificamente o princípio da justiça, os princípios constitucionais processuais do acesso à justiça, da igualdade entre as partes, do direito à prova, do devido processo legal e a regra do artigo 333 e incisos do CPC. Em síntese, a finalidade é demonstrar que os princípios acima citados permitem excepcionar, superar, a

\footnotetext{
${ }^{414}$ FERRAZ JÚNIOR, Introdução ao estudo do direito..., 2003, p. 123-132, leciona que as normas (jurídicas) se classificam conforme critérios sintáticos, semânticos e pragmáticos, ou seja, normas em relação a normas, normas em relação ao objeto normado e normas em relação a sua função. E adverte: esse critério não é rigoroso, mas serve de orientação didática. Prossegue: A) Quanto aos critérios sintáticos classifica as normas de acordo com a relevância, a subordinação e a estrutura. Por sua vez, quanto à relevância, as normas podem ser primárias ou secundárias. Quanto à subordinação, podem ser classificadas em normas-origem e normasderivadas. Quanto à estrutura, as normas jurídicas se distinguem em normas autônomas e normas dependentes; B) Os critérios semânticos trabalham o âmbito de validade das normas jurídicas, se reportando aos destinatários (normas gerais e individuais), à matéria (facti species: normas geral-abstratas, normas especiais e normas excepcionais), ao espaço (nacionais e locais) e ao tempo (normas de validade permanente e normas de validade provisória ou temporária; normas retroativas e irretroativas; normas de incidência imediata e de incidência mediata); C) Quanto aos critérios pragmáticos as normas podem ser classificadas pela força de incidência (normas imperativas, cogentes ou injuntivas e normas dispositivas - normas de ordem pública e de ordem privada), pela finalidade (normas de comportamento ou de conduta e normas programáticas) e pelo funtor, termo originado da lógica (normas preceptivas/funtor deôntico é obrigatório, normas proibitivas/funtor é proibido, normas permissivas / funtor é permitido).
} 
mencionada regra, de forma absolutamente legítima e sem quebrar a harmonia do sistema jurídico.

Entretanto, antes de prosseguir, necessário abrir parêntese com o objetivo de firmar outras premissas condicionantes de nosso raciocínio.

Os princípios e as regras são normas jurídicas distintas. Por sua vez, a distinção entre elas, em âmbito dogmático, foi e é alvo de indeterminados trabalhos científicos, podendo-se até mesmo evidenciar uma verdadeira evolução quanto aos argumentos utilizados para fundamentar a distinção em questão. ${ }^{415}$

Não obstante a grande diversidade conceitual, que acaba por culminar em exacerbada complexidade, foi adotada como linha científico-doutrinária a servir de base ao caminho intelectivo a ser trilhado, o conceito de princípio e de regra instituído por Humberto Ávila. ${ }^{416}$

Em apertada síntese, os princípios são tidos como normas finalísticas, ou seja, que instituem fins a realizar. Exigem para se concretizar e adquirir normatividade, a delimitação de um estado ideal de coisas a ser buscado por meio de comportamentos necessários a essa realização, comportamentos que dependem de atos dos Poderes constituídos, Executivo, Legislativo e Judiciário. Em efeito, a positivação de princípios implica a obrigatoriedade da adoção dos comportamentos necessários a sua realização. ${ }^{417}$

\footnotetext{
${ }^{415}$ Não é nossa finalidade apresentar um rol de autores e suas respectivas distinções em relação aos princípios e regras. Contudo, não podemos deixar de citar os principais juristas que discorreram sobre o tema: Josef Esser, Karl Larenz, Claus-Wilhelm Canaris, sendo os que obtiveram maior destaque, pela profundidade da pesquisa e brilhantismo das conclusões foram, indubitavelmente, Ronald Dworkin e Robert Alexy. Cf. ÁVILA, Humberto Bergmann. Teoria dos princípios: da definição à aplicação dos princípios jurídicos. 10. ed. ampl. atual. São Paulo: Malheiros, 2009. p. 35-40.

$416 \mathrm{O}$ citado autor define princípios como sendo normas imediatamente finalísticas, primariamente prospectivas e com pretensão de complementaridade e de parcialidade, para cuja aplicação se demanda uma avaliação da correlação entre o estado de coisas a ser promovido e os efeitos decorrentes da conduta havida como necessária à sua promoção. As regras são normas imediatamente descritivas, primariamente retrospectivas e com pretensão de decidibilidade e abrangência, para cuja aplicação se exige a avaliação da correspondência, sempre centrada na finalidade que lhes dá suporte ou nos princípios que lhes são axiologicamente sobrejacentes, entre a construção conceitual da descrição normativa e construção conceitual dos fatos. Ibid., p. 78-79.

${ }^{417}$ Cf. Ibid., p. 78-80 e 91.
} 
Assim, v.g., para que o princípio da justiça, inerente ao sistema jurídico, cujo fim a realizar é a justiça, seja transformado de um estado ideal em um estado real de coisas, é necessário um ato de um dos Poderes que o promova efetivamente, que o concretize. No âmbito da jurisdição, para que a justiça se concretize no bojo do direito processual, passando de um estado ideal para um estado real, é necessária a atuação efetiva do juiz, promovendo sua concretude através de atos de poder.

Os princípios possuem ainda, como traço marcante e distintivo, sempre uma pretensão de complementaridade e de parcialidade, pois estabelecem diretrizes valorativas a ser atingidas sem, contudo, estabelecer soluções apriorísticas e específicas. Em efeito, também não estabelecem o comportamento adequado para a concretização desses valores. E, assim, diante da necessidade de proferir uma decisão no caso concreto, o Estado-juiz irá buscar nessas diretrizes valorativas constantes dos princípios, conjuntamente com outras motivações, fundamentos eficazes para seu ato de poder. ${ }^{418}$

Já as regras são normas descritivas, ${ }^{419}$ decisivas e abarcantes. Possuem uma pretensão terminativa, uma pretensão de criar uma solução específica, sendo que o preenchimento das condições de aplicabilidade é a própria razão de aplicação das regras. Entretanto, em relação às regras, ocorre um fenômeno denominado defeasibility, importante para o objetivo proposto e que será adiante aprofundado, que nada mais é que a aptidão da regra para seu próprio cancelamento, quando por razões excepcionais que superam a própria razão que sustenta a aplicação normal da regra, essa não é aplicada, apesar de, inicialmente, estar preenchidas todas as condições de sua aplicabilidade. ${ }^{420}$ As regras, sob essa ótica, se dividem em dois grandes grupos: em regras comportamentais, que descrevem comportamentos como obrigatórios, permitidos ou proibidos e regras constitutivas, que atribuem efeitos jurídicos a determinados atos, fatos ou situações. ${ }^{421}$

Os princípios e as regras apresentam uma diferença primordial para esta pesquisa, relativa à natureza da justificação que exigem para sua respectiva aplicação concreta. Os

\footnotetext{
${ }^{418}$ Nesse sentido ÁVILA, Teoria dos princípios..., 2009, p. 77.

419 As regras descrevem objetos determináveis: sujeitos, condutas, matérias, fontes, efeitos jurídicos, conteúdos. Os princípios, ao contrário, descrevem um estado ideal de coisas a ser promovido. Diferem, assim, dentre outras, quanto à natureza da descrição normativa. Cf. Ibid., p. 83.

${ }^{420}$ Nesse sentido Ibid., p. 77. Cf. nota 5, onde consta o conceito de regra, ipsis litteris, do referido autor.

${ }^{421}$ Nesse sentido Ibid., p. 81.
} 
princípios, quando de sua aplicação, exigem uma avaliação da correlação positiva entre os efeitos da conduta adotada e o estado de coisas que deve ser promovido. Já as regras, exigem um exame de correspondência entre a descrição normativa e os atos praticados ou fatos ocorridos. ${ }^{422}$

Firmados os conceitos e apresentadas as características essenciais das espécies normativas sob análise, necessário enfrentar, doravante, uma das questões fundamentais deste trabalho: a tensão que pode surgir entre um princípio e uma regra, derivada da dinamicidade e complexidade do sistema jurídico. Foi dessa tensão entre o princípio maior do sistema jurídico, o da justiça e a regra rígida que distribui o ônus da prova, que desencadeou a gênese da teoria da dinamização do ônus da prova. Posteriormente, outros princípios de grau constitucional, diante de casos concretos, também se encontraram em tensão com a mencionada regra.

A análise dessa questão obrigatoriamente conduz ao tema da eficácia e da superação das normas, i.e., dos princípios e das regras. A eficácia dessas normas jurídicas também recebe subdivisões classificatórias que não convém detalhar, principalmente por não ser esse o objeto da pesquisa. Não obstante, a análise será reduzida a alguns aspectos da eficácia que são essenciais à verificação da questão proposta, enfatizando o tema da sua superação.

A vexata quaestio é saber qual espécie de norma deve prevalecer diante de existência de uma tensão entre um princípio e uma regra. Mantendo a coerência com a linha doutrinária elegida, por entender que o pensamento de Humberto Ávila guarda uma precisão científico-jurídica ímpar em detrimento dos ensinamentos de Ronald Dworkin e Robert Alexy sobre o assunto, ${ }^{423}$ é possível afirmar que a resposta sofrerá variação conforme a hierarquia das normas em tensão.

\footnotetext{
${ }^{422}$ Nesse sentido ÁVILA, Teoria dos princípios..., 2009, p. 83.

${ }^{423}$ Não se pode desprezar, e não se trata disso, os relevantíssimos estudos realizados por Ronald Dworkin e Robert Alexy, na seara da Filosofia e Teoria Geral do Direito que depois de transportados para o Direito Constitucional, formaram a teoria moderna do Direito Público. Segundo essa teoria os princípios diferem das regras em decorrência de dois fatores: quanto ao modo de aplicação e quanto ao modo como as antinomias entre eles são resolvidas. Quanto à aplicação, os princípios são normas que se aplicam mediante ponderação com outras (sopesamento concreto entre razões colidentes, com atribuição de peso maior a uma delas), enquanto as regras exigem uma aplicação mediante subsunção (correspondência entre o conceito normativo e o conceito do material fático). Na aplicação por ponderação, o aplicador atribuirá uma dimensão de peso aos princípios em colisão, diante do caso concreto. $\mathrm{Na}$ aplicação por subsunção, o aplicador deverá cotejar o
} 
Em efeito, se a tensão se der entre um princípio e uma regra de mesmo nível hierárquico, deverá prevalecer a regra. A regra, diante de uma tensão com um princípio do mesmo nível hierárquico, somente poderá ser superada se houver razões extraordinárias para isso, à luz do postulado da razoabilidade. Esse fenômeno é conhecido por defeasibility of rules. Isso se dá em decorrência da função de concretização que as regras exercem no sistema jurídico, pois são as regras que especificam o comportamento a ser adotado para a concretização das finalidades contidas nos princípios. ${ }^{424}$

Por outro lado, se a tensão ocorrer entre espécies normativas jurídicas que apresentem diversidade hierárquica entre si, ou seja, entre uma norma constitucional e uma norma infraconstitucional, indubitavelmente deverá prevalecer a norma jurídica que for hierarquicamente superior, independentemente da espécie normativa, ou seja, se princípio ou regra. Assim, se a tensão ocorrer entre um princípio constitucional e uma regra legal, deverá prevalecer o princípio. Se a tensão ocorrer entre uma regra constitucional e um princípio legal, a regra. ${ }^{425}$

Estabelecidas tais premissas, não resta dúvida de que diante de uma tensão existente, no caso concreto, entre a regra do artigo 333 e incisos do CPC, norma infraconstitucional, e um dos princípios constitucionais processuais, norma constitucional, deverá prevalecer o princípio, uma vez que consiste em norma jurídica hierarquicamente superior. Também foi formada a convicção de que a regra em destaque, diante do caso

conceito do fato com o conceito constante da hipótese normativa e, se encaixando, aplicar a consequência. Quanto ao modo de resolução das antinomias, o conflito entre princípios ocorre no plano concreto, é contingente e não implica declaração de invalidade de um deles, mas estabelece uma regra de prevalência. Já o conflito entre as regras ocorre no plano abstrato e implica declaração de invalidade de uma delas caso não seja aberta uma exceção. Nesse sentido ÁVILA, Teoria dos princípios..., 2009, p. 87-91. Em seguida o citado autor apresenta inconsistências dessa distinção entre princípios e regras.

${ }^{424}$ Substancialmente nesse sentido ÁVILA, Ibid., p. 103-104. Afirma ainda que a regra consiste em uma espécie de decisão parlamentar preliminar acerca de um conflito de interesses e, por isso mesmo, deve prevalecer em caso de conflito com uma norma imediatamente complementar, como é o caso dos princípios. As regras possuem um grau de pretensão de decidibilidade muito maior do que aquele presente nos princípios, pois a regra é uma espécie de proposta de solução para um conflito de interesses conhecido ou antecipável pelo Poder Legislativo.

${ }^{425}$ Nesse sentido ÁVILA, Ibid., p. 105-106 e 114. Esse entendimento desmistifica o postulado da doutrina juspublicista de que os princípios são as normas mais importantes do ordenamento jurídico e que sua violação seria muito mais grave que a de uma regra. Ao contrário do que a atual exaltação dos princípios poderia fazer pensar, as regras não são normas de segunda categoria. [...], elas desempenham uma função importantíssima de solução previsível, eficiente e geralmente equânime de solução de conflitos sociais. 
concreto, à luz do postulado da razoabilidade, poderá não ser aplicada, sucumbindo à outra regra de semelhante hierarquia, diante do fenômeno do defeasibility of rules. 


\subsubsection{FUNDAMENTOS CONSTITUCIONAIS}

A aplicação da teoria da dinamização do ônus da prova na jurisprudência pátria é uma realidade jurídica, ${ }^{426}$ mesmo sem qualquer dispositivo legal permissivo nesse sentido em âmbito geral, pois como foi visto o diploma especial do CDC adotou sua essência, não obstante ter conferido outra denominação. ${ }^{427}$

Como mencionado anteriormente, a aplicação da teoria sob enfoque, de lege lata, implica automática superação, parcial ou total, da regra geral rígida, estabelecida de forma prévia e abstrata, consignada no artigo 333 e incisos do CPC.

Já foi afirmado ainda que a teoria da dinamização do ônus da prova não tem por objetivo substituir a regra geral de distribuição rígida do ônus da prova. É, a presente teoria, em sua essência, um complemento e aperfeiçoamento dessa regra, desse sistema tradicional do ônus da prova. Não tem a pretensão, por conclusão lógica, ab-rogar ou derrogar tacitamente o artigo legal supra citado inserido no Código de Processo Civil, mas sim, ao seu lado, estabelecer um complemento e aperfeiçoamento desse sistema de distribuição do ônus da prova. Aliás, o regime do artigo 333 e incisos do CPC deverá continuar prevalecendo como regra geral, sendo a aplicação da teoria da dinamização uma exceção, permitida somente naqueles casos concretos que preencherem os requisitos contingentes já mencionados. ${ }^{428}$

A principal justificativa científico-jurídica para a aplicação da teoria da dinamização do ônus da prova de lege lata consiste na necessidade de solucionar, em âmbito teórico-jurídico, a tensão entre normas jurídicas, entre princípios e regras, i.e., solucionar o conflito existente entre determinadas garantias fundamentais constitucionais e o direito positivado processual, no que diz respeito ao dogma da distribuição do ônus da

\footnotetext{
${ }^{426}$ Cf. Título III, seção 3.3.4, onde há vários julgados evidenciando a afirmativa sob enfoque.

${ }^{427}$ Substancialmente nesse sentido DALL AGNOL JÚNIOR, Distribuição dinâmica..., 2001, p. 100, ao afirmar que bem ou mal, inseriu-se ela (a teoria da dinamização do ônus da prova) na primeira (legislação), ao menos na especial, concernente às relações de consumo, [...], e também na última (jurisprudência), segundo o demonstra facilmente pesquisa que se faça nos repositórios.

${ }^{428}$ Cf. Título III, seção 3.2.2.1 - Requisitos de aplicabilidade da dinamização do ônus da prova.
} 
prova e suas consequências diretas e indiretas, que afligem tanto o próprio direito processual quanto o direito material. ${ }^{429}$

Integralizando a afirmativa supra, os fundamentos empíricos que permitem a superação da incidência da regra positivada, podem ser resumidos nas seguintes circunstâncias: quando o ônus da prova pré-fixado pelo artigo 333 e incisos do CPC impossibilitar ou dificultar excessivamente a produção da prova pela parte onerada e quando uma das partes apresentar maior facilidade e melhores condições para a produção da prova essencial à solução da demanda, mesmo que isso ocorra relativamente à parte não onerada. Estes fundamentos complementam-se entre si.

Absolutamente essencial ter em mente que a teoria da dinamização do ônus da prova somente deve ser aplicada quando estiverem presentes ao menos um dos fundamentos científico-jurídicos e um dos fundamentos empíricos, pois é necessário haver uma conjugação entre eles.

\subsubsection{Inafastabilidade da jurisdição}

A teoria da dinamização do ônus da prova deve ${ }^{430}$ ser aplicada quando a regra fixa do diploma legal processual sobre distribuição do onus probandi implicar violação ao artigo $5^{\circ}$, inciso XXXV da Constituição Republicana Brasileira, ou seja, quando excluir, direta ou indiretamente, da apreciação do Poder Judiciário, lesão ou ameaça a direito. ${ }^{431}$

Esse conflito se evidencia quando a regra do artigo 333 e incisos do CPC impossibilitar ou dificultar, direta ou indiretamente, a proteção a ameaça ou lesão a direito material do demandante, a partir do momento que inviabilizar a produção da prova

\footnotetext{
${ }^{429}$ Cf. seção 3.3.1 - Princípios versus regras jurídicas.

${ }^{430}$ A aplicação da teoria da dinamização do ônus da prova, na realidade, não é uma mera faculdade e sim um poder-dever do Estado-juiz, diante do disposto nos artigos $3^{\circ}$, inciso I e $5^{\circ}$ inciso XXXV, ambos da CR/88 e do artigo 125, incisos I e III do CPC. Em relação ao jurisdicionado é um direito subjetivo.

${ }^{431}$ Nesse sentido ARENHART, Ônus da prova..., 2009, p. 358.
} 
dos fatos alegados. ${ }^{432}$ De nada adianta, por um lado, a norma constitucional estabelecer o amplo acesso à justiça, permitindo a ampla e livre alegação de ameaça ou violação a direito e, do outro, uma regra de direito processual impossibilitar ou dificultar a ampla produção da prova. Em termos menos técnicos: o cidadão pode alegar qualquer coisa, mas não tem instrumentos para provar tudo que alega e necessita.

Vale ressaltar que a garantia da tutela jurisdicional somente pode ser concretizada se estiver, efetiva e materialmente, ao alcance de todos, sem qualquer exceção. ${ }^{433}$ Dessa forma, o acesso à justiça somente será obtido em sua concepção integral - amplo e irrestrito acesso, implicando aí o combate à litigiosidade contida, ${ }^{434}$ observância das garantias processuais constitucionais, tempo de desenvolvimento razoável e provimento jurisdicional faticamente útil, quando for adotada e praticada a linha metodológica do processo civil cooperativo e do processo civil de resultados.

$\mathrm{O}$ acesso à justiça é visto na doutrina como princípio-síntese e objetivo final ${ }^{435} \mathrm{da}$ atividade jurisdicional. O grande objetivo, ao se estabelecer garantias constitucionais processuais, incluindo as autolimitações à própria atividade do Estado, que em sua maioria são condensadas na cláusula do devido processo legal, é dar efetividade ao princípio do acesso à justiça. E para tal, necessário priorizar a adoção de medidas que visem ultrapassar dois óbices centrais de nosso sistema na atualidade: a morosidade procedimental e a ausência de efetividade do provimento definitivo.

O sistema processual precisa ser mais rápido sem, contudo, comprometer o acerto de suas decisões e, em decorrência, a justiça do provimento e, concomitantemente, ser eficiente ao ponto desse provimento atender ao interesse/necessidade fático da parte a qual

\footnotetext{
${ }^{432}$ Nesse sentido MITIDIERO, Colaboração..., 2009, p. 127. Afirma, categoricamente, que à vista de determinados casos concretos, pode-se afigurar insuficiente para promover o direto fundamental à tutela jurisdicional adequada e efetiva, uma regulação fixa do ônus da prova, em que se reparte prévia, abstrata e aprioristicamente o encargo de provar (tal como está no art. 333, CPC). Em semelhantes situações, tem o Órgão jurisdicional, atento à circunstância de o direito fundamental ao processo justo, ao nosso devido processo legal processual, implicar direito fundamental à prova, de dinamizar o ônus da prova, atribuindo-o a quem se encontre em melhores condições de provar. Ainda nesse compasso, YARSHELL, Antecipação da prova..., 2009, p. 104, afirma que a imposição do ônus da prova, mesmo quando visto sob a ótica estritamente jurídica, não pode, por eventualmente se apresentar como encargo de tal modo excessivo, atuar como fator impeditivo do acesso à ordem jurídica justa por inviabilizar não apenas o direito à prova, mas a própria garantia da inafastabilidade do controle jurisdicional.

${ }^{433}$ TUCCI, Rogério; TUCCI, José Rogério, Constituição de 1988 e processo..., 1989, p. 19.

${ }^{434}$ Expressão cunhada por Kazuo Watanabe.

435 DINAMARCO, Instituições..., 2009, v. 1, p. 253.
} 
o direito substancial assiste. O resultado, além de justo, tem que ser eficiente ao jurisdicionado, e não somente ao processo como mera e fria atividade do Estado.

O processo não pode ser somente um exercício improdutivo de lógica jurídica, ${ }^{436}$ sob pena de esvair, dia-a-dia, sua legitimidade diante de uma sociedade cada vez mais perceptiva à realidade, consciente de seus direitos e carente quanto à eficiência da prestação Estatal, inclusive em âmbito do Poder Judiciário.

Processo civil de resultados, processo justo ou processo équo, são expressões que cunham, na essência, um mesmo objetivo dentro do sistema processual: o de dar efetividade ao princípio do acesso à justiça, servindo de autêntico instrumento de condução à ordem jurídica justa. ${ }^{437}$ Processo efetivo e justo é aquele cujo resultado garante a paz pública, a certeza, a segurança jurídica e a educação dos jurisdicionados. ${ }^{438}$

\subsubsection{Igualdade entre as partes}

A teoria da dinamização do ônus da prova deve ser igualmente aplicada quando a regra fixa do diploma legal processual sobre distribuição do onus probandi implicar violação ao artigo $5^{\circ}$, caput da Constituição Republicana Brasileira, ou seja, quando proporcionar, direta ou indiretamente, desigualdade, desequilíbrio entre as partes a ponto de impossibilitar ou dificultar, direta ou indiretamente, a produção da prova dos fatos alegados.

Em outras palavras, a teoria da dinamização impõe-se ser aplicada quando, diante do caso concreto, o juiz se deparar com uma efetiva violação ao princípio constitucional da igualdade das partes ou da isonomia, denominado em âmbito processual civil como princípio da paridade de armas - parità nelle armi.

\footnotetext{
${ }^{436}$ DINAMARCO, Instituições..., 2009, v. 1, p. 117.

${ }^{437}$ Afirma DINAMARCO, Ibid., v. 1, p. 118 e 253, que só tem acesso à ordem jurídica justa quem recebe justiça. E receber justiça significa ser admitido em juízo, poder participar, contar com a participação adequada do juiz e, ao fim, receber um provimento jurisdicional consentâneo com os valores da sociedade. Tais são os contornos do processo justo, ou processo équo, que é composto pela efetividade de um mínimo de garantias de meios e de resultados.

${ }^{438}$ LOPES, Maria Elizabeth de Castro. O juiz e o princípio dispositivo. São Paulo: Editora Revista dos Tribunais, 2006. p. 151.
} 
A igualdade ou isonomia entre as partes consiste na própria essência da democracia sendo, portanto, para aquelas nações que a adotam, um dos princípios basilares da existência do próprio Estado. Nossa Constituição Republicana, ainda em seu preâmbulo, institui a igualdade como um valor supremo da nossa sociedade. Em seguida, logo no caput do seu primeiro artigo, estabelece que a República Federativa do Brasil constitui-se em Estado Democrático de Direito. Ao assim se definir deixou óbvio que a igualdade e a legalidade são diretrizes principiológicas inarredáveis de nossa Pátria e do nosso Estado de Direito.

Como se não bastasse, pois desnecessário qualquer outro dispositivo a respeito, o constituinte ratificou tais diretrizes ao consignar no caput do artigo $5^{\circ}$ da Carta Magna, a igualdade como direito e garantia fundamental. Afirmou que todos os brasileiros são iguais perante a lei, sem qualquer espécie de distinção, o que, aliás, já tinha sido firmado como objetivo fundamental de nossa República, no inciso IV do artigo $3^{\circ}$, do diploma legal em comento. $^{439}$

Em âmbito do direito processual civil, o princípio constitucional da isonomia tem sua maior expressão no princípio da paridade de armas. Na realidade, trata-se de um princípio processual corolário do princípio constitucional em questão, sob uma visão sistêmica. Desse princípio derivam várias regras procedimentais e processuais a ser observadas por todos, mormente pelo Estado-juiz. Muitos juristas sintetizam esse princípio com a frase "tratar com igualdade os iguais e desigualmente os desiguais, na medida de suas desigualdades".

Na essência, o grande desafio do magistrado, diante desse princípio, consiste em observá-lo em sua inteireza, o que implica não criar desigualdades para as partes e em

\footnotetext{
${ }^{439}$ Nós, representantes do povo brasileiro, reunidos em Assembléia Nacional Constituinte para instituir um Estado Democrático, destinado a assegurar [...], a igualdade e a justiça como valores supremos de uma sociedade [...], promulgamos, sob a proteção de Deus, a seguinte CONSTITUIÇÃO DA REPÚBLICA FEDERATIVA DO BRASIL. Art. $1^{\circ}$ A República Federativa do Brasil, [...], constitui-se em Estado Democrático de Direito [...] Art. $3^{\circ}$ Constituem objetivos fundamentais da República Federativa do Brasil: [...] IV - promover o bem de todos, sem preconceitos de origem, raça, sexo, cor, idade e quaisquer outras formas de discriminação. Art. $5^{\circ}$ Todos são iguais perante a lei, sem distinção de qualquer natureza, garantindo-se aos brasileiros e aos estrangeiros residentes no País a inviolabilidade do direito à [...], à igualdade, [...].
} 
neutralizar as que porventura existam. ${ }^{440}$ Nesse contexto, apresenta-se a teoria da dinamização do ônus da prova como instrumento eficaz à neutralização das desigualdades fáticas e processuais, evidenciadas pelo magistrado, diante do caso concreto, levando-se em consideração as circunstâncias peculiares que lhe são apresentadas na demanda, quanto à pertinente matéria probatória. ${ }^{441}$

Em âmbito do direito positivado infraconstitucional, o direito processual civil brasileiro também estabeleceu regras que coadunam com o valor da igualdade entre as partes. O artigo 125, mormente os incisos I e III do vigente Código de Processo Civil, confere poderes e impõe a obrigação ao Juiz de assegurar igualdade de tratamento às partes, bem como de prevenir e reprimir qualquer ato contrário à dignidade da justiça, inserindo-se nessa espécie qualquer ato atentatório à igualdade. Em efeito, ad abundantiam, a teoria sob enfoque é um instrumento eficaz para promover de forma efetiva a igualdade entre as partes, principalmente em âmbito probatório, sendo sua aplicação, também diante dessa regra de natureza processual, uma verdadeira obrigação do Estado-juiz. ${ }^{442}$

Não há dúvidas, assim, que a necessidade de eliminar as desigualdades no processo não só justifica a existência como também a afetiva aplicação da teoria da dinamização do ônus da prova no processo civil brasileiro de lege lata. ${ }^{443}$

\subsubsection{Direito à prova e devido processo legal}

\footnotetext{
${ }^{440}$ Nesse sentido DINAMARCO, Instituições..., 2009, v. 1, p. 213.

441 DINAMARCO, Ibid., p. 213, afirma que essas desigualdades são resultantes de fatores externos ao processo - fraquezas de toda ordem, como a pobreza, desinformação, carências culturais e psicossociais em geral. Chama a atenção para a necessidade de promover prioritariamente a igualdade substancial entre as partes. Sustenta que neutralizar desigualdades significa promover a igualdade substancial, que nem sempre coincide com uma formal igualdade de tratamento porque esta pode ser, quando ocorrentes essas fraquezas, fonte de terríveis desigualdades. A tarefa de preservar a isonomia consiste, portanto, nesse tratamento formalmente desigual que substancialmente iguala.

${ }^{442}$ Cf. nota 412 .

${ }^{443}$ Nesse sentido MITIDIERO, Colaboração no processo..., 2009, p. 127.
} 
A teoria da dinamização do ônus da prova deve ser também aplicada quando a regra fixa do diploma legal processual sobre distribuição do ônus da prova implicar violação à garantia fundamental e constitucional à prova.

Foi afirmado anteriormente que a prova é um direito e garantia constitucional das partes. Sob outra perspectiva, a do direito processual, o direito à prova consiste em verdadeiro direito público subjetivo das partes à produção de provas no bojo do processo civil. Esse direito subjetivo à prova é um direito público, pois tem como sujeito passivo, ou seja, como destinatário, o Estado-Juiz. Este, por sua vez, diante da natureza desse direito, tem o dever de dar efetividade à instrução probatória, o que implica promover a livre iniciativa probatória das partes, a participação e o controle das mesmas em todas as fases probatórias, não adotando medidas que visem limitar ou restringir o exercício do direito a ampla produção de prova. ${ }^{444}$

Nesse contexto, o direito à prova pode ser conceituado como sendo o conjunto de oportunidades oferecidas à parte pela Constituição Republicana e pela lei infraconstitucional, para que possa demonstrar no processo a veracidade do que afirmam em relação aos fatos relevantes para o julgamento. ${ }^{445}$ Desta forma, sob o ângulo constitucional, consiste na ampla liberdade de acesso às fontes e meios segundo o disposto em lei inferior.

Em efeito, quando a regra rígida do artigo 333 do CPC impõe a uma das partes a produção de determinada prova que lhe é difícil ou impossível, está flagrantemente violando o direito dessa parte à ampla produção de prova, a partir do momento que a outra parte, não onerada, tem melhores condições de produzi-la.

A afirmativa supra é facilmente perceptível sob o ângulo do princípio maior do processo civil. O direito à prova, como garantia constitucional, tem como fonte a expressa cláusula constitucional do devido processo legal. Quando se fala na cláusula do devido processo legal vem à mente, de imediato, dois grupos de palavras-chaves que, agindo de forma interligada entre si, formam a estrutura conceitual e, ao mesmo tempo,

\footnotetext{
${ }^{444}$ Cf. Título I, seção 1.2 - Prova como direito et seq.

${ }^{445}$ Nesse sentido DINAMARCO, Instituições..., 2009, v. 3, p. 46.
} 
as delimitações teórico-jurídicas da referida cláusula: estado-democrático-de-direito e garantias-processuais-constitucionais. A cláusula sob enfoque vem expressa no artigo $5^{\circ}$, inciso LIV, da CR/88, nos seguintes termos: "ninguém será privado da liberdade ou de seus bens sem o devido processo legal".

Em uma primeira leitura, é possível abstrair, singelamente, que em nosso país, regido por normas que caracterizam um Estado Democrático de Direito, nenhum cidadão será privado de sua liberdade, bem como de quaisquer de seus bens, a não ser por intermédio do devido processo legal. Ou seja, uma vez observado, em sua inteireza, o devido processo legal, qualquer cidadão pode ter sua liberdade e seus bens privados pelo Estado.

Mas o que exatamente é e qual a extensão teórico-dogmática dessa cláusula constitucional? Poder-se-ia, a priori, defini-la como sendo o conjunto de garantias processuais constitucionais, que visam disciplinar o poder do Estado no exercício desse próprio poder, o jurisdicional, adotando como paradigma princípios inerentes a um Estado Democrático de Direito, como é a República Federativa do Brasil (artigo 1º, caput, da $\mathrm{CR} / 88)$.

Sob outra ótica, é através dessa cláusula que o processo - instrumento escolhido pelo constituinte para o exercício da jurisdição, através do Poder Judiciário - tem suas regras disciplinadoras fixadas na seara constitucional.

É possível afirmar ainda que todos os direitos de natureza processual que estiverem inseridos no contexto dessa cláusula são elevados à garantia constitucional. Contudo, fácil perceber que essa cláusula não é taxativa, ou seja, tais garantias processuais constitucionais não estão expressas, carecendo de interpretação sistemática a fim de identificá-las.

Não se objetiva, na presente tese, identificar detalhadamente quais são essas garantias. Entretanto, a doutrina é pacífica ao reconhecer as seguintes: garantia da igualdade entre as partes; garantia da imparcialidade do juiz; garantia do juiz natural; garantia do contraditório. 
Vale ressaltar, ainda em tempo, que na doutrina são assentes dois pontos relevantes sobre a mencionada cláusula: o primeiro diz respeito à reconhecida dificuldade de conceituação e delimitação da extensão do devido processo legal, ${ }^{446}$ o segundo consiste na reconhecida existência de uma dimensão substantiva da cláusula - substantive due process of law - ligada aos princípios do regime democrático de governo e à autolimitação do poder estatal.

Decorre ainda da cláusula do devido processo legal o paradigma de processo a reger toda a atividade jurisdicional, tendo como pilares mores os princípios e ideologias que caracterizam a democracia e o Estado de direito. Esse paradigma de processo, esse modelo de processo, traduz-se no denominado processo justo e équo, regido por garantias de meios e resultados, oferecendo às partes reais e equilibradas oportunidades.

Retomando o foco, a garantia processual constitucional consistente no direito à prova não está expressa na Carta Magna, sendo corolário da cláusula do devido processo legal, ${ }^{447}$ esta sim, ali consignada. Sem sombra de dúvidas, o direito à prova é considerado um dos pilares fundamentais do sistema processual moderno.

Essa constatação se deve, dentre outras, à relevância empírica do direito probatório na ciência processual. Sem sua concretização não se vislumbra efetiva a própria garantia constitucional do direito ao processo ${ }^{448}$ e do acesso à Justiça. A sua concretização está, em efeito, diretamente ligada à formação do provimento jurisdicional e à legitimidade da coisa julgada material.

$\mathrm{Na}$ esfera infraconstitucional o direito à prova pode ser indiretamente abstraído do disposto no artigo 332 do Código de Processo Civil que estabelece que todos os meios legais, bem como os moralmente legítimos, ainda que não especificados no referido diploma legal, são hábeis para provar a verdade dos fatos, em que se funda ação ou a defesa, bem como do disposto no artigo 32 da Lei 9.099/95 que disciplina que todos os

\footnotetext{
${ }^{446}$ Nesse sentido DINAMARCO, Instituições..., 2009, v. 1, p. 250 e 253. Afirma ser a cláusula due process of law caracterizada por uma amplitude indeterminada e que não interessa determinar, bem como [...] amorfa e enigmática, cujo conceito e conteúdo mais se colhem pelos sentimentos e intuição, do que pelos métodos puramente racionais da inteligência.

${ }^{447}$ Nesse sentido YARSHELL, Antecipação da prova..., 2009, p. 90. Afirma o autor que a prova se insere no contexto da garantia-síntese que é o devido processo legal.

${ }^{448}$ DINAMARCO, Instituições..., 2009, v. 3, p. 46.
} 
meios de prova moralmente legítimos, ainda que não especificados em lei, são hábeis para provar a veracidade dos fatos alegados pelas partes. Esses dois dispositivos legais asseguram tanto o direito às fontes probatórias (obtidas de forma legítima) quanto aos meios de prova (técnicas processuais pertinentes à realização da prova no processo). Pode ainda ser inferido, na citada esfera infraconstitucional, dos dispositivos legais constantes do Código de Processo Civil, do Código Civil e de leis especiais pertinentes às fontes de prova. 


\subsubsection{FUNDAMENTOS SISTÊMICOS}

\subsubsection{Justiça: razão e fim axiológico do sistema jurídico}

A nossa Carta Magna de 1988, em seu artigo $3^{\circ}$, inciso I, instituiu como valor fundamental da República Federativa do Brasil o valor justiça. ${ }^{449}$ Ao instituir a justiça como um valor fundamental, não só o estabeleceu em âmbito programático, como também o tornou imperativo aos agentes políticos. Assim, o valor justiça deve guiar todo o agir do Estado brasileiro e, consequentemente, toda a atividade dos três Poderes Constituídos. Desta forma, todo o agir do Estado deve estar voltado a efetivar esse valor fundamental e isso implica, por um lado, adotar medidas que o implementem e, do outro, não adotar qualquer medida que promova injustificada restrição ao valor sob enfoque. ${ }^{450}$

Como afirmado anteriormente, a aplicação do artigo 333 e incisos do CPC, em determinadas situações concretas, fere o valor fundamental da justiça, por estabelecer um ônus à determinada parte, o da produção de prova dos fatos alegados, que lhe é impossível ou que implica extrema dificuldade.

O dogma da justiça, independentemente de sua concepção filosófica e histórica, é axiologicamente analisando, a norma fundamental ${ }^{451}$ do sistema jurídico. O valor justiça, em sua concepção abstrata, é a razão axiológica da existência do sistema jurídico e, ao mesmo tempo, em sua concepção concreta, a finalidade deste. O cidadão vai ao Poder Judiciário, buscar a justiça que entendeu desrespeitada faticamente (justiça em abstrato), porque sabe que esse Poder tem sua razão existencial nesse valor, e, ao final, receberá do competente Poder, a justiça (em concreto). Mesmo que não concorde com a justiça proferida pelo Poder Judiciário ao final, o valor justiça estará sempre presente. São comuns, em linguagem popular, as expressões: "Vou à Justiça" (local); "a justiça está ao meu lado” (concepção abstrata); “A justiça foi feita neste caso” (concepção concreta).

\footnotetext{
${ }^{449}$ Cf. nota 414 da seção 3.3.2.2.

${ }^{450}$ Nesse sentido ÁVILA, Teoria dos princípios..., 2009, p. 95.

${ }^{451} \mathrm{O}$ termo foi utilizado aqui, mutatis mutantis, em sentido similar à norma fundamental de Hans Kelsen.
} 
A justiça é um valor absoluto, como a verdade, o bem ou a beleza o são; um valor que descansa, portanto, em si mesmo e não deriva de outro superior. A medula da justiça é a idéia de igualdade. Sua essência é a igualdade. A justiça afasta a idéia do geral e aspira sempre à análise do caso concreto e do indivíduo concreto, em sua individualidade. Essa justiça projetada sobre o caso concreto e sobre o homem concreto recebe o nome de equidade. $^{452}$

Desde Aristóteles se distinguem duas classes de justiça: a justiça comutativa e a justiça distributiva. Cada uma delas tem uma forma distinta de conceber o postulado da igualdade. Segundo Aristóteles a justiça comutativa representa a igualdade absoluta entre uma prestação e uma contraprestação, v.g., entre o comércio e o preço, entre o dano e a reparação, entre a culpa e a pena. A justiça comutativa pressupõe a existência de duas pessoas juridicamente equiparadas entre si. Já a justiça distributiva preconiza a igualdade proporcional no trato dado a diferentes pessoas, por exemplo, a repartição entre elas dos tributos fiscais levando em consideração a capacidade contributiva de cada um. A justiça distributiva, ao revés da comutativa, pressupõe três pessoas no mínimo: uma delas é colocada em um plano superior, e impõe ônus ou confere benefícios às demais, subordinadas a ela. ${ }^{453}$

O processo é um organismo teleológico pensado por e para o valor justiça. ${ }^{454}$ Essa "justiça processual" que se espera do processo compreende todas as suas fases, do início ao encerramento, além do efetivo cumprimento do mandamento enunciado na decisão definitiva. Todos os princípios, institutos, regras e fenômenos de natureza processual devem estar balizados no valor justiça, bem como voltados para esse fim.

O valor justiça é o objetivo síntese da jurisdição no plano social, restando muito pobre a indicação isolada do escopo jurídico como característica da jurisdição e do sistema processual. $^{455}$

\footnotetext{
${ }^{452}$ RADBRUCH, Gustav. Introducción a la filosofia del derecho. Trad.Wenceslao Roces. México: Fondo de Cultura Económica, 1951. p. 32-33. (Tradução nossa). Afirma ainda o autor que "la pauta axiológica del derecho positivo y meta del legislador es la justicia.".

${ }^{453}$ Cf. PEYRANO, Cargas probatorias dinámicas, 2008, p. 32.

${ }^{454}$ Substancialmente PEYRANO, Ibid., p. 33, nota 26.

${ }^{455}$ Substancialmente nesse sentido DINAMARCO, A instrumentalidade..., 2008, p. 347.
} 
$\mathrm{Na}$ atualidade, resta patente que a "justiça processual" tem estreita ligação com a justiça distributiva de Aristóteles. A “justiça processual” deve preconizar a igualdade proporcional no trato dado às diferentes partes.

E é exatamente essa a idéia central da teoria da dinamização do ônus da prova: distribuir esse ônus, diante do caso concreto, em estrita observância à igualdade proporcional, avaliando e identificando as desigualdades em âmbito de produção de provas para, em seguida, equilibrar, ao máximo, as diferenças que impedem a concretização do valor justiça.

\subsubsection{Visão cooperativa do processo e a produção da prova}

O princípio cooperativo é um consenso no processo civil pós-moderno do início do século XXI. Baseia-se na idéia de comunidade de trabalho entre o magistrado e as partes, buscando a paz jurídica entre os litigantes e, dessa forma, a paz de toda a comunidade. ${ }^{456}$ Assim, as partes, conjuntamente, devem se preocupar e trabalhar no sentido de facilitar para o juiz a segura obtenção da verdade. ${ }^{457}$

A idéia fecunda da cooperação, que inclui a de solidariedade, dentro do processo e no tocante à obtenção e produção da prova, tem como finalidade precípua, a melhor prestação jurisdicional. $^{458}$

\footnotetext{
${ }^{456}$ Nesse sentido OLIVEIRA, Carlos Alberto Alvaro de. Poderes do juiz e visão cooperativa do processo. Revista da Ajuris, v. 30, n. 90, p. 55-84, 2003. p. 65.

${ }^{457} \mathrm{Na}$ lição de Leo Rosenberg, a essência do processo civil moderno reside numa comunidade de trabalho (arbeitsgemeinschaft) entre o juiz e as partes, que conjuntamente devem se preocupar em facilitar ao primeiro a segura obtenção da verdade e restabelecer num procedimento vivo a paz jurídica entre as partes litigantes, assegurando desse modo a paz da comunidade. In Lehrbuch. 6. ed. [S.1.: s.n.], 1956. p. 6. Apud OLIVEIRA, Ibid., p. 65, nota 34 .

${ }^{458}$ Desde que Marcel Storme efetuou uma lúcida crítica à concepção de direito processual que colocava sobre os ombros do autor o peso da iniciativa, impulso e, principalmente, da produção probatória, relegando ao requerido um acompanhamento quase passivo e de mero expectador, as mudanças nessa leitura parcial e errônea foram copérnicas. $\mathrm{O}$ jurista belga desnudou uma realidade distinta na qual a cooperação se distribuía às partes e a obra de estruturar e definir o litígio era comum e dependia da ativa participação de ambos. Que os fins públicos da jurisdição hão de abastecer a concorrente e sincronizada tarefa das partes envolvidas com a paz social e os resultados justos que devem apresentar uma sentença de mérito. Desfecho de um processo justo e do esforço compartido de descobrir a verdade jurídica objetiva respeitando os fatos relevantes e as circunstancias afirmadas na demanda (Tradução nossa). In MORELLO, Dificultades de la prueba..., 2004, p. 49 e 73. CAPPELLETTI, Mauro. La oralidad y las pruebas en el proceso civil. Traducción de Santiago
} 
Na doutrina estrangeira há uma verdadeira obrigação de cooperação para se chegar à verdade no âmbito do processo. ${ }^{459}$

A visão solidarista de cooperação no âmbito da jurisdição - ter consciência que é um trabalho em comum - e, buscando efetivar seus resultados, impõe, sob a perspectiva do ônus da prova, de forma precípua, que nenhuma das partes possa, legitimamente, se refugiar no interesse individualista da parte onerada. A visão solidarista do encargo de provar, superando a de feição individualista, retira de posição demasiado subalterna valores que merecem ser resgatados, principalmente, a verdade e a justiça.

Às vezes as circunstâncias fáticas farão com que o ônus da prova passe para o outro postulante em razão deste se encontrar em melhores condições de obtê-la e produzi-la, seja quanto ao conhecimento fático, profissionalismo, habitualidade ou técnica. ${ }^{460} \mathrm{Ou}$ seja, em âmbito probatório, o princípio da solidariedade obriga àquela parte que se encontra em melhores condições de produzir a prova, a fazê-lo. ${ }^{461}$

Não se pode esquecer que a cooperação no processo se instrumentaliza através de princípios, garantias e técnicas processuais, objetivando de um lado facilitar o trabalho do juiz e de outro, incentivar e desenvolver a colaboração das partes. ${ }^{462}$ Em outra vertente, a cooperação, no processo, se materializa em ônus e deveres processuais que recaem sobre o

Santis Melendo. Buenos Aires: EJEA, 1972. p. 123-124, firmou, sobre o tema, posição no sentido de que uma vez instaurado um processo civil, o modo, o ritmo, o impulso do próprio processo são separados da disponibilidade imediata ou mediata das partes, i.e., a forma de desenvolvimento do processo estaria desvinculada do poder de disponibilidade das partes, estando, ao revés nas mãos do juiz, detentor de poderes discricionários, no exercício dos quais ele poderia e deveria ter em conta as concretas exigências do caso, em um verdadeiro espírito de ativa colaboração com as partes e estas com o juiz.

${ }^{459}$ V.g., a doutrina argentina. Cf. MORELLO, Dificultades de la prueba..., 2004, p. 49. Nesta obra o autor se refere especificamente à obtenção coativa de sangue a fim de realizar a prova hematológica. PATTI, Prove..., 1987 , p. 21, em relação ao ordenamento italiano, afirma que se configura no mesmo uma obrigação geral de colaboração e de lealdade no processo. (tradução nossa).

${ }^{460}$ Nesse sentido MORELLO, Dificultades de la prueba..., 2004, p. 50.

461 Nesse sentido MORELlO, Augusto M. La prueba. Tendencias modernas. Buenos Aires: PlatenseAbeledo Perrot, 1991. p. 58-59. Afirma ainda, na mesma obra e páginas, que a própria experiência demonstra que, ao menos em algumas matérias, [...], a uma das partes, e não à outra - ou mesmo ao órgão judicial -, é mais cômodo realizar a prova. Por via de consequência, é aquela que deveria desenvolver a conduta diligente e útil ao resultado eficaz. [...] Tudo isso desemboca em uma bem entendida funcionalidade do princípio de cooperação (ou de efetiva cooperação), que, a sua vez, radica no mais compreensivo e de maior força operativa, que é o da solidariedade. E ambos no da boa-fé. (tradução nossa).

${ }^{462}$ Nesse sentido OLIVEIRA, Poderes do juiz e visão cooperativa..., 2003, p. 79. 
juiz, as partes e também sobre terceiros alheios à relação jurídica processual, devendo todos, conjuntamente, atuar em colaboração. ${ }^{463}$

Nessa linha de pensamento, forma-se a convicção de que a teoria da dinamização do ônus da prova é um instrumento processual inserido nos contornos científicos do princípio cooperativo, pois se harmoniza perfeitamente com suas finalidades precípuas, ou seja, facilitar o trabalho do juiz e fomentar a colaboração das partes na busca da verdade.

A visão cooperativa do processo, democrática por excelência, pois incentiva a maior participação das partes na atividade processual e na formação e construção da convicção do magistrado e do próprio provimento jurisdicional definitivo, confere à atividade do juiz maior grau de legitimidade, justamente diante dessa postura democrática, em detrimento de uma postura autoritária. ${ }^{464} \mathrm{O}$ juiz do processo cooperativo é um juiz isonômico na condução do processo, ou seja, paritário no diálogo, e assimétrico quando da decisão das questões processuais e materiais da causa, desempenhando duplo papel, uma vez que ocupa posições e exerce funções diferentes nessa relação processual.

Em nossos dias, indiscutível que a cooperação converte-se em uma prioridade no processo e que a atividade do juiz se torna cada vez mais complexa. ${ }^{465}$ Diante disso e,

\footnotetext{
${ }^{463}$ Nesse sentido PEYRANO, Jorge W. El principio de cooperación procesal. [S.1.: s.n.], [19--]. Disponível em: <http://www.elateneo.org/doctrina-J-W--Peyrano.php>. Acesso em: 29 agosto 2010. p. 2. O autor, ao estabelecer os contornos do princípio da cooperação processual afirma que se trata de um princípio, diferentemente de outros, que floresce em ônus e em deveres processuais que pesam não somente sobre as partes, mas também sobre terceiros absolutamente alheios ao processo. Mas em todos os seus pressupostos seu funcionamento revela que o processo civil deve ser considerado como uma empresa comum cujo feliz resultado (a definição adequada do que foi discutido) exige a colaboração de ambas as partes e também, eventualmente, a de outros sujeitos compelidos legalmente a prestar sua assistência para a consecução do mencionado objetivo. Conclui seu pensamento sustentando que a existência do princípio de cooperação processual explica e legitima o funcionamento de vários ônus e deveres processuais que, de outra forma, não teriam justificação. (tradução nossa).

${ }^{464}$ TROCKER, Processo civile e costituzione..., 1974, p. 724, afirma que a escolha do meio de prova e a busca da verdade deve derivar de uma cooperação entre os vários protagonistas do processo. (tradução nossa).

465 Nesse sentido MORELlO, Augusto Mario. El proceso civil moderno. La Plata: Platense, 2001. p. 474475. Afirma ainda o autor, na mesma obra e páginas, que sobre o "principio de colaboración en el proceso importa señalar, muy destacadamente, que él es hoy considerado por la doctrina como un verdadero “componente' del proceso justo, de juego decisivo e importante inspirador de la moderna disciplina procesal y sobre el cual es mucho lo que puede razonarse. [...] El derecho procesal necesario debe navegar en las aguas de una colaboración constante y efectiva de los sujetos procésales, como quiera que su ausencia o un modo retaceado de prestársela conspira contra los fines públicos de la jurisdicción.”.
} 
apesar disso, o princípio da cooperação processual exige um mínimo, e não um máximo, ${ }^{466}$ de colaboração dos sujeitos do processo, juiz, partes e ainda terceiros, na obtenção do objetivo que é comum e transcende a lide e os interesses particulares dos litigantes.

Não é demais reafirmar que o princípio da cooperação processual, ${ }^{467}$ que abraça toda a atividade processual, com mais ou menos vigor, de acordo com o princípio, garantia ou técnica processual que se refere, explica a existência e a extensão de várias disposições legais, ${ }^{468}$ bem como, entendimentos jurisprudenciais dominantes, justificando cientificamente o funcionamento de vários ônus e deveres processuais. ${ }^{469}$

O próprio Código de Processo Civil vigente em nosso país tratou de estabelecer essa ligação ao dispor em seu artigo 339, de forma explícita, o dever geral, erga omnes, de colaboração com o Poder Judiciário para o descobrimento da verdade, incluindo, aí, indubitavelmente e principalmente, as partes. ${ }^{470}$

Em âmbito de direito positivado infraconstitucional, o princípio da colaboração no processo civil pátrio encontra sua maior expressão no artigo acima mencionado, mas não somente. $\mathrm{O}$ artigo 14 do mesmo diploma legal, ao disciplinar a respeito dos deveres das partes, fixa uma série de condutas que decorrem nitidamente do princípio de colaboração no processo civil, dentre elas a de expor os fatos em juízo em conformidade com a

\footnotetext{
${ }^{466}$ Nesse sentido PEYRANO, El principio de cooperación..., [19--], p. 4 e 7. No original: "el principio de cooperación procesal reclama un mínimun y no un máximun de colaboración de las partes y de terceros en la señalada empresa común, pero, eso sí, cuando corresponde su funcionamiento puede ser intensa la colaboración exigida.".

${ }^{467}$ Nesse sentido MITIDIERO, Colaboração no processo..., 2009, p. 124 e 127. O autor afirma que a doutrina tem aludido à possibilidade de dinamizar o ônus da prova, fundamentando a partir do caso concreto a repartição do encargo probatório. Esse expediente [...], encontra-se em total consonância com a idéia de processo civil pautado pela colaboração, pressupondo mesmo para sua aplicação um modelo de processo civil cooperativo.

${ }^{468}$ Cf., v.g., artigo 14 e incisos; artigo 412, caput, ambos do CPC.

${ }^{469}$ Nesse sentido PEYRANO, op. cit., p. 7 (nota 463). No original: "El principio de cooperación procesal explica la existencia y alcances de numerosas disposiciones legales y soluciones pretorianas dominantes; justificando, asimismo, el funcionamiento de varias cargas y deberes procesales; debiendo ponerse de resalto que algunos de estos últimos encuentran igualmente respaldo en la concurrencia de lo que puede denominarse Servicio Público Judicial que compromete a todos los ciudadanos en la empresa común consistente en disfrutar de un proceso civil eficaz.".

${ }^{470}$ Substancialmente nesse sentido BARBOSA MOREIRA, Julgamento..., 1988. p. 77. Afirma o autor que ambos os litigantes são convocados a colaborar no descobrimento da verdade, independentemente dos respectivos interesses. [...] é que a lei espera de um e de outro que não omitam de caso pensado "fatos essências ao julgamento da causa" [...]. Há um dever de esclarecimento, que não corre apenas à parte interessada. Ainda nesse sentido DALL AGNOL JÚNIOR, Distribuição dinâmica..., 2001, p. 93, nota 5. Sustenta que se ninguém se exime do dever de colaborar com o Poder Judiciário para o descobrimento da verdade, difícil, por vezes, sustentar-se a ausência de dever da própria parte para o alcance desse desiderato.
} 
verdade, a de proceder com lealdade e boa-fé, a de não produzir provas, nem praticar atos inúteis ou desnecessários à declaração ou defesa do direito, a de não criar embaraços à efetivação de provimentos judiciais, a de cumprir com exatidão os provimentos mandamentais.

Necessário ressaltar, em sede conclusiva, que as novas codificações, principalmente dos países europeus de origem civil law, v.g., Portugal, ${ }^{471}$ Espanha, ${ }^{472}$ França, ${ }^{473}$ apesar de não abandonarem o princípio dispositivo, fortaleceram flagrantemente a posição do juiz no processo, mitigando o caráter privado do processo, publicizando-o cada vez mais e consagrando, expressamente, o princípio cooperativo processual. O mesmo fenômeno ocorre na Argentina, através do Código Processual Civil da Nação.

Por derradeiro, insta apresentar uma divergência existente entre a doutrina e a jurisprudência italiana a respeito da aplicação do princípio da colaboração e da distribuição do ônus da prova que demonstra, dentre outros fatores, a existência e a efetiva aplicação de um dever de colaboração no mencionado ordenamento estrangeiro e a aplicação da teoria da dinamização do ônus da prova sob a denominação de "inversão" do ônus da prova naquele ordenamento.

Em ações ajuizadas por pacientes ou seus herdeiros em face de médicos, a lei italiana dispõe que o ônus da prova quanto aos pressupostos da responsabilidade do médico

\footnotetext{
${ }^{471}$ No relatório do Decreto-lei n ${ }^{\text {o }}$ 329-A/1995, que instituiu o Código de Processo Civil de Portugal, consta expressamente: Consagra-se o princípio da cooperação, como princípio angular e exponencial do processo civil, de forma a propiciar que juízes e mandatários cooperem entre si, de modo a alcançar-se, de uma feição expedita e eficaz, a justiça do caso concreto; [...].

${ }^{472}$ Em âmbito de execução civil a Ley de Enjuiciamiento Civil de España (Ley 01/2000) contém disposição expressa. Artículo 591. Deber de colaboración. 1. Todas las personas y entidades públicas y privadas están obligadas a prestar su colaboración en las actuaciones de ejecución y a entregar al tribunal cuantos documentos y datos tengan en su poder, sin más limitaciones que los que imponen el respeto a los derechos fundamentales o a los límites que, para casos determinados, expresamente impongan las leyes. 2. El tribunal, previa audiencia de los interesados, podrá, mediante providencia, imponer multas coercitivas periódicas a las personas y entidades que no presten la colaboración que el tribunal les haya requerido con arreglo al apartado anterior. En la aplicación de estos apremios, el tribunal tendrá en cuenta los criterios previstos en el apartado 3 del artículo 589.

${ }^{473}$ O Código de Processo Civil da França, segundo modificação instituída pelo Decreto 542, de 23.06.2003, contém disposição expressa. Título I. Disposições preliminares. Capítulo I. Os princípios norteadores do processo. Seção IV: A prova. Artigo 11. Las partes tienen la obligación de colaborar en la práctica de las pruebas; el tribunal operará las consecuencias oportunas en caso de que se abstengan o rechacen hacerlo. Si una parte tuviera en su poder un elemento de prueba, el tribunal, a petición de la parte contraria, podrá requerirle para que lo aporte, bajo apercibimiento de multas coercitivas. El tribunal también podrá, a petición de una de las partes, solicitar u ordenar, bajo idéntico apercibimiento, la aportación de todos aquellos documentos que estuvieran en poder de un tercero, si no existe impedimento legítimo.
} 
é da parte autora, ou seja, do paciente ou herdeiros. Contudo, obviamente, não fecha os olhos à realidade no tocante ao fato de que os documentos e os meios de prova em geral estão, normalmente, na posse do próprio médico ou dos responsáveis pela estrutura hospitalar.

Diante disso, a jurisprudência italiana, majoritariamente, para fazer frente à dificuldade da prova do paciente, limita seu ônus probatório e grava sobre o médico o ônus de provar que os efeitos dos danos afirmados pelo paciente não foram provocados por uma inadequada prestação profissional, i.e., deve provar que não há nexo de causalidade entre sua conduta e os alegados danos.

A doutrina italiana, apesar de reconhecer que essa posição jurisprudencial merece aprovação porque facilita a tutela jurisdicional a favor da parte que sofreu os danos, afirma que, na realidade, é imposta à parte adversária um ônus de produção de prova que a lei não estabelece. A lei italiana estabelece o dever do médico em fornecer em juízo o material probatório, em cumprimento à obrigação de esclarecimento - obbligo di chiarimento.

Para a doutrina, a jurisprudência fez uma confusão, misturando a obrigação de esclarecimento (colaboração com o descobrimento da verdade) com a distribuição do ônus da prova. A obrigação de colaborar com o descobrimento da verdade serve para facilitar a formação da convicção do magistrado, mas não incide sobre o ônus da prova - regra de juízo. A sanção relativa ao inadimplemento da obrigação de esclarecimento não pode ser a mesma consequência da ausência de cumprimento do ônus da prova, gravada sobre a parte contrária.

Em efeito, vem prevalecendo a posição da jurisprudência italiana que "inverte" parcialmente o ônus da prova, em tais hipóteses, determinando assim que o risco da ausência de convencimento do magistrado - ausência de certeza da matéria fática -, recaia sobre a parte que deveria simplesmente adimplir com a obrigação de esclarecimento, com a obrigação de colaborar na descoberta da verdade. ${ }^{474}$

${ }^{474}$ Cf. PATTI, Prove..., 1987, p. 21-24. 


\subsubsection{APLICAÇÃO DA DINAMIZAÇÃO NA JURISPRUDÊNCIA}

Apresentados os elementos conceituais, estruturais e os fundamentos da aplicabilidade da teoria da dinamização do ônus da prova nos capítulos e seções anteriores, torna-se necessário, averiguar se a jurisprudência brasileira vem acolhendo, na prática forense, a teoria sob enfoque, bem como ainda sob quais parâmetros estruturais e sob quais fundamentos, visando testificar, cientificamente, a presente pesquisa.

Não se trata de adotar o empirismo ou mesmo o pragmatismo como únicas fontes de conhecimento científico, mas como métodos complementares de criação e certificação científica do presente trabalho. ${ }^{475}$

Nesse intuito, apresenta maior relevância a jurisprudência formada nos Tribunais Superiores e naqueles Tribunais de Justiça que exercem maior influência - dimensões institucional, objetiva e de eficácia do precedente judicial ${ }^{476}$ - no cenário jurídico do país, bem como ainda aquelas decisões consideradas paradigmáticas.

Necessário, desde já, registrar que foram identificados reiterados julgados em nossa jurisprudência que aplicaram a teoria da dinamização do ônus da prova, utilizaram os fundamentos de aplicabilidade anteriormente apresentados, mas denominaram o fenômeno como "inversão" do ônus da prova. ${ }^{477}$

No Supremo Tribunal Federal e no Tribunal Superior Eleitoral não há precedentes.

No Superior Tribunal de Justiça a teoria ainda não foi acolhida expressamente. Entretanto, não há dúvida que a essência da teoria da dinamização do ônus da prova vem sendo aplicada, principalmente em demandas envolvendo matéria ambiental, sob o fundamento de incidência do denominado princípio da precaução, princípio específico de direito ambiental, sob o fundamento legal da "inversão" do ônus da prova, mas com seu

\footnotetext{
475 Empirismo é a doutrina segundo a qual todo conhecimento (prático) tem sua origem na experiência. Pragmatismo é a doutrina filosófica que adota como critério da verdade a utilidade prática, identificando o verdadeiro com o útil. In FERREIRA, Pequeno dicionário..., [19--].

${ }^{476}$ TUCCI, Precedente judicial..., 2004, p. 305-307.

${ }^{477}$ Esse equívoco foi exaustivamente demonstrado no Título III, seção 3.2.1.4.
} 
campo de incidência ampliado, i.e., extrapolando os limites do Código de Defesa do Consumidor..

Esse preceito, intitulado princípio da precaução, foi utilizado pela Corte em referência para justificar o deferimento de pedidos de "inversão" do ônus da prova, regra geral apresentados pelo Ministério Público Federal, em ações civis públicas visando a tutela do meio ambiente, nas quais segundo a citada parte autora, haveria o efetivo risco de ocorrer um dano sério ou irreversível ao meio ambiente, sendo necessária assim a implementação de medidas que pudessem prever e prevenir esse dano.

Entretanto, digno de destaque em relação a esses pedidos e respectivas concessões judiciais, é que a própria parte autora, não tinha como identificar e, assim, demonstrar em sede preambular do processo, os alegados sérios e irreversíveis danos ao meio ambiente. Diante dessas incertezas, o meio ambiente, segundo o dito princípio da precaução, deve ter em seu favor o benefício da dúvida sobre o nexo causal entre determinada atividade e uma consequência que possa degradá-lo. Este entendimento vem sendo aplicado pela primeira e segunda turma do STJ.

No recurso especial interposto pelo Ministério Público do Rio Grande do Sul em face da empresa Amapá do Sul S/A Artefatos de Borracha, ${ }^{478}$ visando atacar decisão da segunda instância que entendeu ser dele a responsabilidade de comprovar a ocorrência do dano ambiental provocado pela fábrica, uma vez que era o autor da demanda e requerente da realização da perícia, juntamente com a Fundação Zoobotânica daquele estado, argumentou que a "inversão" do ônus da prova, por este pleiteada, decorre diretamente da transferência do risco para o potencial poluidor, devendo ser remetido ao empreendedor todo o encargo de prova de que sua atividade não enseja riscos para o meio ambiente.

A Ministra Eliana Calmon acolheu o mencionado pedido de "inversão" do ônus da prova, sob o fundamento de que em se tratando de ações civis ambientais, o caráter público e coletivo do bem jurídico tutelado leva à conclusão de que alguns dos direitos do consumidor também devem ser estendidos ao autor daquelas ações, uma vez que tais

\footnotetext{
${ }^{478}$ STJ. $2^{\text {a }}$ Turma. REsp. 972.902/RS (2007/0175882-0). Rel. Min. Eliana Calmon. Julgado em 25/8/2009. Publicação DJe 14/09/2009.
} 
demandas buscam resguardar ou reparar o patrimônio público de uso coletivo. Portanto, a partir da interpretação do art. $6^{\circ}$ da Lei $n^{\circ} 8.078 / 90$ e do art. 21 da Lei $n^{\circ}$ 7.347/85, conjugado ao princípio da precaução, firmou-se o entendimento de que é justificável a "inversão" do ônus da prova, transferindo para o empreendedor da atividade potencialmente perigosa o ônus de demonstrar a segurança do empreendimento.

Em outro precedente, desta vez da primeira turma, o relator Ministro Francisco Falcão, determinou a "inversão" do ônus da prova, em uma ação civil pública que discutia ser as queimadas decorrentes das fagulhas geradas pelo deslocamento das composições ferroviárias da empresa responsável pelo transporte da produção agrícola daquele estado, ao julgar recurso interposto pela All-America Latina Logística do Brasil S/A em face de decisão do Tribunal de Justiça do Estado do Rio Grande do Sul. ${ }^{479}$ Para o Ministro Francisco Falcão, o princípio da precaução sugere que o ônus da prova seja sempre "invertido" de modo que o produtor do empreendimento ou responsável técnico tenha que demonstrar a ausência de perigo ou dano decorrente da atividade em que atuam.

O Ministro Herman Benjamin, sobre o princípio da precaução, enfatizou que este inaugura uma nova fase para o próprio Direito Ambiental, no qual já não cabe aos seus titulares provar efeitos negativos (ofensividade) de empreendimentos levados à apreciação do Poder Público ou do Poder Judiciário, como é o caso dos instrumentos filiados ao regime de simples prevenção (exemplo: estudo de impacto ambiental), impondo-se aos degradadores potenciais o ônus de corroborar a inofensividade de sua atividade proposta, principalmente naqueles casos nos quais eventual dano possa ser irreversível ou de difícil reversibilidade ou de larga escala.

479 STJ. $1^{\text {a }}$ Turma. REsp. 1049822/RS (2008/0084061-9). Rel. Min. Francisco Falcão. Julgado em 23/04/2009. Publicado em 18/05/2009. 
Ainda nessa seara, em acórdão mais recente, ${ }^{480}$ o STJ definitivamente marcou nova racionalidade jurídica no julgamento de ações ambientais ao demonstrar que a distribuição rígida do ônus da prova, insculpida no artigo 333, incisos I e II do CPC, se parece adequada para a maioria das lides, consiste em um empecilho processual no caso das ações ambientais. Isso ocorre porque a regra rígida desconsidera as dificuldades naturais de prova do nexo de causalidade entre a atividade exercida e a degradação, bem como também ignora um princípio fundamental do direito ambiental: o de que a adoção de medidas para evitar a ocorrência de danos ambientais não deve ser protelada, nem mesmo nos casos em que não há certeza científica do dano. Essa última justificativa, como se demonstrou, é consagrada pelos Ministros do Superior Tribunal de Justiça sob a denominação de princípio da precaução.

Ad abundantiam, esta nova racionalidade jurídica acolhida pelo STJ implica admitir a "inversão" do ônus da prova em casos de empresas ou empreendedores acusados de dano ambiental, i.e., cabe ao próprio acusado provar que sua atividade não enseja riscos à natureza. $\mathrm{O}$ entendimento se baseia na idéia de que, quando o conhecimento científico não é suficiente para demonstrar a relação de causa e efeito entre a ação do empreendedor e uma determinada degradação ecológica, o benefício da dúvida deve prevalecer em favor do meio ambiente, o que se traduz na expressão in dubio pro ambiente, ou interpretação mais amiga da natureza.

Depreende-se, assim, do conteúdo dos parágrafos anteriores, que os casos mencionados, na essência, não versam sobre "inversão" do ônus da prova, consistindo, na realidade em aplicação da teoria da dinamização do ônus da prova. ${ }^{481}$

\footnotetext{
${ }^{480}$ STJ. $2^{\text {a }}$ Turma. REsp. 1060753/SP (2008/0113082-6). Rel. Min. Eliana Calmon. Julgado em 01/12/2009. Publicado em 14/12/2009. Em apertada síntese, com o proferimento desse decisum, pacificou-se o entendimento no STJ, quanto a julgamentos de ações por dano ambiental, no sentido de ser aplicado o princípio da precaução. Este princípio pressupõe a inversão do ônus probatório, competindo a quem supostamente promoveu o dano ambiental comprovar que não o causou ou que a substância lançada ao meio ambiente não lhe é potencialmente lesiva, segundo a Ministra Eliana Calmon. O julgamento sob enfoque envolveu a emissão de um suposto poluente - o carbonato de cálcio - por uma empresa de transportes e armazenagem do interior de São Paulo. Ao interpretar o disposto no Código de Defesa do Consumidor sob a lente da gestão preventiva do dano ambiental, os ministros do STJ transferiram para o empreendedor da atividade potencialmente lesiva o ônus de demonstrar a segurança da atividade.

${ }^{481}$ Cf. Título III, seção 3.2.1.4 - Dinamização versus inversão do ônus da prova.
} 
A prova produzida pela parte requerida, suposta degradante do meio ambiente, não é constitutiva do direito do autor, regra geral do Ministério Público e sim, impeditiva, modificativa ou extintiva do direito daquele, in casu, da coletividade, ou seja, a parte requerida deverá provar que não está degradando, que não deu causa a degradação ocorrida ou, ainda, que sua atividade não tem potencial ofensivo ao meio ambiente.

A fundamentação utilizada pelo Superior Tribunal de Justiça para aplicar a “inversão" do ônus probatório consistiu, como dito, no princípio da precaução. Todavia, nos exemplos acima citados, a parte requerida tinha melhores condições, mais facilidade, em produzir a prova essencial à demanda, principalmente quanto à inofensividade ao meio ambiente decorrente de suas atividades.

Diversamente do que ocorre no Superior Tribunal de Justiça, o Tribunal Superior do Trabalho acolhe expressamente a teoria da dinamização do ônus da prova.

Além de reiterados acórdãos, a citada Corte editou a Súmula 338, cujo inciso III, apesar de trazer a expressão "inversão" do ônus da prova, estabelece verdadeira hipótese de dinamização do ônus da prova, conferindo o ônus da prova ao empregador, parte requerida, por ser àquela parte que possui maior facilidade na produção da prova pertinente às horas extras, em circunstância específica, em seu bojo fixada. ${ }^{482}$ Desta forma, em demanda que o empregado reivindique o pagamento de horas extras, caso os cartões de ponto apresentados nos autos evidenciem horários de entrada e saída uniformes, estes serão

\footnotetext{
482 Súmula 338 do TST, inciso III: Os cartões de ponto que demonstram horários de entrada e saída uniformes são inválidos como meio de prova, invertendo-se o ônus da prova, relativo às horas extras, que passa a ser do empregador, prevalecendo a jornada da inicial se dele não se desincumbir. Seguindo a diretriz sumular: TST. $6^{\text {a }}$ Turma. AIRR 1.378/2004-373-04-40.0. Min. Rel. Mauricio Godinho Delgado. Julgado em 11/06/2008. Ementa. Agravo de Instrumento. Recurso de Revista. Horas Extras. Folhas Individuais de Presença. Ônus da Prova. Segundo a jurisprudência do TST, os cartões de ponto que demonstram horários de entrada e saída uniformes são inválidos como meio de prova, invertendo-se o ônus da prova relativo às horas extras, que passa a ser do empregador, prevalecendo a jornada declinada na inicial se dele não se desincumbir. Inteligência da Súmula 338, III/TST. Agravo de instrumento desprovido. Não obstante o teor do Enunciado 338 do TST, entende-se que em estabelecimento com mais de dez empregados, incumbe ao empregador o ônus da prova quanto à jornada de trabalho por eles executada. $\mathrm{O}$ artigo 74, parágrafo segundo, da CLT, prevê o dever do empregador manter anotação da hora de entrada e saída de seus empregados. Por se tratar de prova pré-constituída em poder de uma das partes, esta é uma das hipóteses de exceção à teoria distributiva do onus probandi no processo civil e trabalhista, cujas regras estão no artigo 333, incisos I e II, do CPC, combinado com o artigo 818 da CLT. A prova da jornada de trabalho do trabalhador, nesta circunstância, cabe à parte empregadora, independentemente de comando judicial nos autos, isso porque somente a ela são dados os meios de controle burocráticos do horário de trabalho, imprescindíveis à prova em questão.
} 
tidos por inválidos como meio de prova (presunção relativa judicial), devendo o empregador, doravante, provar que o empregado não trabalhou as horas extras requeridas, ou seja, a jornada que descreveu na peça vestibular.

Os precedentes de aplicação da teoria da dinamização do ônus da prova, no Tribunal Superior do Trabalho, vão muito além da matéria sumulada. ${ }^{483}$

Nos Tribunais Regionais do Trabalho de Minas Gerais e Bahia, a teoria é amplamente aplicada. ${ }^{484}$

No Tribunal de Justiça de São Paulo a teoria da dinamização do ônus da prova foi aplicada em vários julgados, em demandas de diversas naturezas, v.g.: a) cobrança de expurgos inflacionários; ${ }^{485}$ b) indenização c/c obrigação de fazer; ${ }^{486}$ c) ação civil pública

483 TST. $3^{\text {a }}$ Turma. AIRR-1558/2005-008-17-40.8. Min. Rel. Carlos Alberto Reis de Paula. Julgado em 24/09/2008; TST. 3 a Turma. RR-423/2006-151-18-00.6. Min. Rel. Carlos Alberto Reis de Paula. Julgado em 24/09/2008. Ementa. Recurso de Revista. Pagamento de Salários. O Reclamado chamou a si o ônus da prova, consoante o consagrado no princípio da aptidão para a prova, pelo qual a prova deverá ser produzida por aquela parte que a detém ou que tem acesso a ela, sendo inacessível à parte contrária. Consequentemente, é a que se apresenta como apta a produzi-la judicialmente. Recurso conhecido e provido. [...] O que se verifica é que o Município, ao sonegar os contracheques ou as fichas financeiras, gerou presunção relativa a favor da Reclamante, sendo certo que não logrou comprovar, por outro meio de prova, que procedeu ao correto pagamento dos salários e, portanto, não se desincumbiu de provar o fato impeditivo do direito da Reclamante. O Reclamado chamou a si o ônus da prova, consoante o consagrado no princípio da aptidão para a prova, pelo qual a prova deverá ser produzida por aquela parte que a detém ou que tem acesso a ela, sendo inacessível à parte contrária. Consequentemente, é a que se apresenta como apta a produzi-la judicialmente. 484 TRT-MG. $8^{\text {a }}$ Turma. RO 00601-2006-097-03-00-0. Rel. Márcio Ribeiro do Valle. Publicado em 18/11/2006. DJMG, p. 20; TRT-MG. $3^{\text {a }}$ Região. $2^{\text {a }}$ Turma. RO 00756-2004-091-03-00-6. Rel. Des. Sebastião Geraldo de Oliveira. Publicado em 22/07/2009. DEJT, p. 57; TRT-MG. $3^{\text {a }}$ Região. $2^{\text {a }}$ Turma. RO 003430045.2009.5.03.0072. Rel. Des. Sebastião Geraldo de Oliveira. Publicado em 21/07/2010. DEJT, p. 66; Julgados com base na Súmula 338, inciso III do TST: TRT-BA. 5 ${ }^{\mathrm{a}}$ Região. 5 ${ }^{\mathrm{a}}$ Turma. RO 007110010.2009.5.05.0010. Rel. Des. Paulino César Martins Ribeiro do Couto. Julgado em 01/06/2010; TRT-BA. 5 Região. 5a Turma. RO 0030300-45.2004.5.05.0161. Rel. Des. Esequias de Oliveira. Julgado em 30/06/2010; TRT-MG. 3 $3^{\mathrm{a}}$ Região. $3^{\mathrm{a}}$ Turma. RO 0086500-42.2009.5.03.0003. Juiz Rel. Convocado Vitor Salino de Moura Eça. Publicado em 24/05/2010. DEJT, p. 47. Ementa. Inversão do Ônus da Prova. Técnica de Julgamento. Dispondo uma das partes de documentos cujo porte e manutenção são obrigatórios, o dever de exibição dos mesmos é integralmente seu. Todavia, verificando o Juiz do Trabalho que os mesmos não merecem a menor credibilidade, eis que totalmente divorciados do usual, a simples oferta do meio probatório não o desonera. E considerando-se a maior aptidão de uma das partes para a produção da prova, o que a doutrina qualifica como distribuição dinâmica do ônus da prova, temos como consequência que tal encargo permaneça com o empregador, em virtude dos fatos excepcionais que apontou. Afinal o ordinário se presume e o extraordinário deve ser provado, não obstante os ditames do art. 818/CLT. Destarte, se os cartões de ponto deixam de mostrar qualquer variação horária ao longo dos dias neles retratados, fato que foge absolutamente da realidade, há inexorável deslocamento do ônus probatório, com sua inversão, de modo a que o empregador comprove que a jornada constante dos documentos é verdadeira, sob pena de, ante o insucesso, ver-se condenado a satisfazer o pedido correlato.

485 TJSP. $34^{\text {a }}$ Câmara de Direito Privado. AI 992090587706 (1248845600). Rel. Antonio Nascimento. Julgado em 24/08/2009; TJSP. 34 ${ }^{a}$ Câmara de Direito Privado. AI 1236620008. Rel. Antonio Nascimento. Julgado em 18/05/2009; 
visando tutela do meio ambiente; ${ }^{487}$ d) relação de consumo; ${ }^{488}$ e) regime de cooperativismo; ${ }^{489} \mathrm{f}$ ) dano moral com base na lei de imprensa; ${ }^{490} \mathrm{~g}$ ) prestação de serviços de telefonia móvel; ${ }^{491}$ h) dano moral decorrente de inscrição em cadastro de inadimplentes; ${ }^{492}$ i) ação monitória fundada em contrato escrito e assinado de prestação de serviços educacionais ${ }^{493}$ j) rescisão de contrato de compra e venda de bem imóvel. ${ }^{494}$

O Tribunal de Justiça do Rio Grande do Sul segue a mesma linha. Merece destaque a aplicação da mencionada teoria, de forma categórica, principalmente em demandas envolvendo tutela do meio ambiente. Foi proferido acórdão paradigma quanto à aplicação da dinamização do ônus da prova em matéria de direito ambiental, abaixo citado, ${ }^{495}$ no qual restou consolidado que a questão relativa ao ônus probatório tem base constitucional. Na motivação desse acórdão foram firmadas premissas de grande importância para a teoria da dinamização do ônus da prova, até porque foi a teoria que serviu de base para a motivação do decisum: a) que em demandas dessa natureza - direito ambiental - incide o princípio supralegal da carga dinâmica da prova ou do ônus probatório dinâmico; b) que o ônus probatório compete a quem dispõe dos elementos de prova, pois, o ônus flutua entre uma e outra parte conforme as circunstâncias; c) não há necessidade de ser invocado o Código de Defesa do Consumidor em relação à “inversão” do ônus da prova.

\footnotetext{
${ }^{486}$ TJSP. $3^{\text {a }}$ Câmara de Direito Privado. AI 6593374300. Rel. Beretta da Silveira. Julgado em 01/09/2009;

${ }^{487}$ TJSP. Câmara Especial de Meio-Ambiente. AI 8963215300. Rel. Samuel Júnior. Julgado em 25/06/2009; TJSP. Câmara Especial de Meio-Ambiente. AI 8115745500. Rel. Samuel Júnior. Julgado em 07/05/2009; TJSP. Câmara Especial de Meio-Ambiente. AI 8474545600. Rel. Samuel Júnior. Julgado em 07/05/2009.

${ }^{488}$ TJSP. $3^{\text {a }}$ Câmara de Direito Privado. AI 6207304700. Rel. Beretta da Silveira. Julgado em 17/02/2009.

${ }^{489}$ TJSP. $4{ }^{\text {a }}$ Câmara de Direito Privado. AI 5566954500. Rel. Francisco Loureiro. Julgado em 24/04/2008.

490 TJSP. $4^{\text {a }}$ Câmara de Direito Privado. Apelação Cível 4703834500. Rel. Francisco Loureiro. Julgado em $13 / 12 / 2007$.

${ }^{491}$ TJSP. $26^{\text {a }}$ Câmara de Direito Privado. Apelação Cível 992090845004 (1297678000). Rel. Carlos Alberto Garbi. Julgado em 29/09/2009; TJSP. $26^{a}$ Câmara de Direito Privado. Apelação Com Revisão 1269820000. Rel. Carlos Alberto Garbi. Julgado em 23/09/2009; TJSP. 26a Câmara de Direito Privado. Apelação Com Revisão 1253531006. Rel. Carlos Alberto Garbi. Julgado em 12/05/2009.

${ }_{492}$ TJSP. $37^{\mathrm{a}}$ Câmara de Direito Privado. Apelação Com Revisão 7359001100. Rel. Tasso Duarte de Melo. Julgado em 02/09/2009.

${ }^{493}$ TJSP. $26^{\mathrm{a}}$ Câmara de Direito Privado. Apelação Com Revisão 1257390004. Rel. Carlos Alberto Garbi. Julgado em 28/04/2009.

${ }_{494}$ TJSP. $9^{a}$ Câmara de Direito Privado B. Apelação 5089624800. Rel. José Luiz Germano. Julgado em 27/03/2009.

${ }^{495}$ TJRS. $1^{a}$ Câmara Cível. AI no 70011843224 . Rel. Carlos Roberto Lofego Canibal. Julgado em 09/11/ 2005. Insta colacionar trecho do voto: “..., incide o princípio supralegal da carga dinâmica da prova ou do ônus probatório dinâmico, ou seja, na realidade o ônus probatório compete a quem dispõe dos elementos de prova. O ônus flutua entre uma e outra parte conforme as circunstâncias. No caso, à evidência, se a atividade considerada ofensiva ao meio ambiente é exercida pelas demandadas, óbvio que os elementos de prova hábeis à demonstração de que tal não ocorre estão em poder delas. Cabe-lhes provar que não há ofensa ao meio ambiente, e não a sociedade, difusamente considerada, que é a vítima. Quer isso dizer que à inversão do ônus da prova, não há, no caso, sequer necessidade de ser invocado o CDC". (transcrição ipsis litteris ).
} 
Importante frisar que nesse mesmo acórdão, decidindo ação civil pública que visava tutela ressarcitória por danos ao meio ambiente, entendeu-se pela inaplicabilidade da "inversão" do ônus probatório diante da legitimidade da dinamização do ônus da prova. Sustentou-se ainda que a idéia de acessibilidade à Justiça não pode resultar restrição ao acesso aos tribunais, mas deve ser compreendida como modo de viabilizar o acesso à ordem jurídica justa e plena, ao bem da vida buscado na ação.

A teoria da dinamização do ônus da prova é também fartamente utilizada, pelo Tribunal de Justiça em menção, em demandas envolvendo erro médico. ${ }^{496}$ Nesse sentido, quanto à demandas de outras naturezas. ${ }^{497}$

No Tribunal de Justiça de Minas Gerais ${ }^{498}$ e do Paraná ${ }^{499}$ a teoria da dinamização também é acolhida e aplicada em sua inteireza.

496 TJRS. 1 a Câmara Cível. ApCív no 597083534. Rel. Armínio José Abreu Lima da Rosa. Julgado em 03/12/1997; TJRS. $9^{a}$ Câmara Cível. AI no 70018912667. Rel. Desa. Íris Helena Medeiros Nogueira. Julgado em 21/03/2007; TJRS. 5 ${ }^{a}$ Grupo de Câmaras Cível. Emb.Infringentes nº 70017662487. Rel. Odone Sanguiné. Julgado em 31/08/2007.

${ }^{497}$ TJRS. $3^{\text {a }}$ Câmara Especial Cível. Apelação Cível 70029451481. Rel. Des. Maria José Schmitt Sant`Anna. Julgado em 11/08/2009. Ementa: Apelação Cível. Política Salarial. Inciso I, do Artigo 13, da Lei Estadual $n^{\circ}$. 10.395/95. Inexistência de Fato Notório. Dinamização do Ônus Da Prova. I. Quando a parte autora alega que não lhe foram implementados determinados reajustes decorrentes do artigo 10.395/95, sendo impossível verificar apenas pelo seu contracheque que não houve tal pagamento, é possível a dinamização do ônus da prova, para que, em atenção ao direito fundamental à paridade de armas, a parte ré demonstre que efetivamente implementou os reajustes em questão, sob pena de ser julgado procedente o pedido formulado na petição inicial. II. A implementação dos reajustes previstos nos incisos I, II e III, da Lei Estadual $\mathrm{n}^{\circ}$. 10.395/95, não pode ser considerada como fato notório, de modo a ficar, se for o caso, isenta de prova tal qual prevê o artigo 334, I, do Código de Processo Civil.

${ }^{498}$ TJMG. 11 a Câmara Cível. Apelação Cível 1.0024.07.690796-3/001. Rel. Des. Selma Marques. Julgado em 01/04/2009; TJMG. 11 ${ }^{\mathrm{a}}$ Câmara Cível. Apelação Cível 1.0145.07.428950-8/002. Rel. Des. Selma Marques. Julgado em 01/04/2009; TJMG. $11^{\mathrm{a}}$ Câmara Cível. Embargos de Declaração Cível 1.0145.07.428950-8/003. Rel. Des. Selma Marques. Julgado em 24/06/2009; TJMG. 11 a Câmara Cível. Agravo de Instrumento 1.0024.08.289973-3/001. Rel. Des. Marcos Lincoln. Julgado em 02/12/2009; TJMG. $11^{\mathrm{a}}$ Câmara Cível. Apelação Cível 1.0024.08.248925-3/001. Rel. Des. Selma Marques. Julgado em 12/05/2010; TJMG. 11 a Câmara Cível. Apelação Cível 6449913-54.2009.8.13.0024. Rel. Des. Selma Marques. Publicado em 12/04/2010 - Ementa: Apelação Cível - Rescisão Contratual - Contrato de Prestação de Serviços - Código de Defesa do Consumidor - Aplicabilidade - Falha na Prestação do Serviço Dinamização Ônus da Prova - Comprovação - Dano Moral - Mero Aborrecimento. Demonstrado o descumprimento das condições previstas no contrato entabulado pelas partes, tendo em vista a plena aplicação da dinamização do ônus da prova, imperativa se mostra a rescisão pretendida. [...] Esta forma de distribuição dos ônus probatórios - dinamização do ônus da prova - esta diretamente imbricada com o direito material posto em causa e as facilidades que uma das partes, em detrimento da outra, encontraria na produção da prova destinada a suprir os pontos controversos da demanda. [...] neste sentido: "de outro lado, o ônus da prova pode ser atribuído de maneira dinâmica, a partir do caso concreto pelo juiz da causa, a fim de atender à paridade de armas entre os litigantes e às especificidades do direito material afirmado em juízo. não há nenhum óbice constitucional ou infraconstitucional à dinamização do ônus da prova no processo civil brasileiro. muito pelo contrário. à vista de determinados casos concretos, pode se afigurar insuficiente, para 


\section{PERSPECTIVAS DE INSERÇÃO DA DINAMIZAÇÃO DO ÔNUS DA PROVA NO DIREITO POSITIVO}

\subsection{LEY N 01/2000 - LEY DE ENJUICIAMIENTO CIVIL DE ESPAÑA}

A lei processual civil espanhola, reformulada através da Lei $\mathrm{n}^{\circ}$ 01/2000, denominada Ley de Enjuiciamiento Civil, consagrou a teoria da dinamização do ônus da prova ao dispor, expressamente, no item 7 do artigo 217, que disciplina o ônus da prova, que o Tribunal, ao aplicar a regra geral sobre a distribuição do ônus da prova normatizada nos itens 2 e 3 do citado artigo ${ }^{500}$ deverá considerar a disponibilidade e a facilidade de cada parte em produzir a prova que lhe incumbe. ${ }^{501}$

Em efeito, a lei processual civil espanhola, além de estar na vanguarda quanto à inserção da teoria da dinamização do ônus da prova no âmbito do direito positivo, ainda estabeleceu outro avanço de ordem técnico-jurídico, ao inserir o presente tema, i.e., o ônus

promover o direito fundamental à tutela jurisdicional adequada e efetiva, uma regulação fixa do ônus da prova, em que se reparte prévia, abstrata e aprioristicamente o encargo de provar. em semelhantes situações, tem o órgão jurisdicional, atento à circunstância de o direito fundamental ao processo justo implicar direito fundamental a prova, dinamizar o ônus da prova, atribuindo-o a quem se encontre em melhores condições de provar. (transcrição ipsis litteris).

499 TJPR. $1^{\text {a }}$ Câmara Cível. Agravo de Instrumento 0597671-4. Rel. Des. Dulce Maria Cecconi. Julgado em 13/07/2009; TJPR. 1ª Câmara Cível. Agravo de Instrumento 0599334-4. Rel. Des. Dulce Maria Cecconi. Julgado em 15/07/2009. TJPR. $1^{a}$ Câmara Cível. Agravo de Instrumento 0599982-0. Rel. Des. Dulce Maria Cecconi. Julgado em 20/07/2009. Insta colacionar trecho do voto deste último acórdão: "De acordo com a teoria da carga dinâmica, é possível a flexibilização do esquema básico do ônus da prova em determinados casos concretos especialmente naqueles em que, face à suas peculiaridades, a prova se torna excessivamente difícil para a parte onerada e, em contrapartida, mais facilitada àquela inicialmente desonerada. Assim, serve a doutrina para os casos em que se coloca uma dificuldade de prova de uma das partes em relação à outra, mesmo nos casos não contemplados pela lei. [...] Nesse sentido, a distribuição dinâmica do ônus da prova vem a prestigiar o dever de cooperação para a descoberta da verdade que, a par de positivado no art. 339 do Código de Processo Civil, decorre da própria concepção pós-moderna de processo, na sua condição de instrumento público para realização da justiça e da pacificação social. Um processo cooperativo, uma comunidade de trabalho entre partes e juiz, tudo pela busca do fim comum: o campo probatório, a busca da verdade possível e, por via de consequência, a justa composição do litígio.”. (transcrição ipsis litteris).

${ }^{500}$ Artículo 217. Carga de la prueba. 2. Corresponde al actor y al demandado reconviniente la carga de probar la certeza de los hechos de los que ordinariamente se desprenda, según las normas jurídicas a ellos aplicables, el efecto jurídico correspondiente a las pretensiones de la demanda y de la reconvención. 3. Incumbe al demandado y al actor reconvenido la carga de probar los hechos que, conforme a las normas que les sean aplicables, impidan, extingan o enerven la eficacia jurídica de los hechos a que se refiere el apartado anterior. 501 Artículo 217. Carga de la prueba. 7. Para la aplicación de lo dispuesto en los apartados anteriores de este artículo el tribunal deberá tener presente la disponibilidad y facilidad probatoria que corresponde a cada una de las partes del litigio. 
da prova e sua distribuição, na seção que disciplina os requisitos internos da sentença (Sección II. De los requisitos internos de la sentencia y de sus efectos), ao invés de inserilo na parte que versa sobre as provas em geral, como normalmente é disposto nas legislações de vários países. ${ }^{502}$

Isto representa uma irrefutável solidificação do dogma do ônus da prova como regra de julgamento, minimizando, senão eliminando, os argumentos da minoria doutrinária que tende a sustentar uma maior relevância do ônus subjetivo da prova, distorcendo toda a estrutura teórica do instituto.

Entretanto, mesmo antes da inserção da teoria da dinamização do ônus da prova no arcabouço positivo, o Tribunal Supremo da Espanha já havia acolhido critérios de flexibilização do ônus da prova, essencialmente com suporte teórico-jurídico na obrigação de colaboração dos litigantes com o órgão judicial no descobrimento da verdade e no "princípio" da facilidade, i.e., o dever de quem tem maior facilidade e possibilidade de provar.

Pode-se afirmar que no país sob menção, o exigir a prova de quem a tenha facilmente em sua disposição, consiste em entendimento jurisprudencial consolidado. Diante disso depreende-se, em síntese, que o ônus da prova pode recair tanto sob o autor quanto sob o requerido, segundo circunstâncias do caso e a própria situação processual das partes, ou seja, pode ser imposta àquela parte que esteja em melhores condições de produzir a prova em juízo, independentemente de ser autor ou requerido. O ônus da prova, assim, não é distribuído somente pela invocação de um fato, mas também pela possibilidade de sua produção em juízo. ${ }^{503}$

A doutrina espanhola afirma que as partes não possuem o direito de se esconder na mera negativa das alegações apresentadas pela parte contrária. Ainda, sustenta que a superioridade técnica, a situação de prevalência, a melhor aptidão probatória ou a índole ou complexidade do fato apresentado na demanda, são causas de modificação do ônus da prova para quem esteja em melhores condições de provar.

\footnotetext{
${ }^{502}$ Nesse sentido PEYRANO, Marcos L. La teoria de las “cargas probatorias dinámicas" en la flamante ley de enjuiciamiento civil española (ley 1/2000). In PEYRANO, Cargas probatórias..., 2008, p. 191-192.

503 Nesse sentido CARBONE, Carlos Alberto. Cargas probatorias dinámicas: una mirada al derecho comparado y novedosa ampliación de su campo de acción. In PEYRANO, Cargas probatórias..., 2008, p 212.
} 


\subsection{PROJETO DE LEI No 3.015/2008}

A teoria da dinamização do ônus da prova é objeto de Projetos de Leis visando sua inserção no direito positivo pátrio desde 2008. Doravante, serão abordadas as iniciativas legislativas concretizadas através dos Projetos de Lei $n^{\circ} 3.015 / 2008$ e $n^{\circ}$ 5.139/2009 e, por último e o mais importante deles, o Projeto do Senado nº 166/2010, que visa criar um novo Código de Processo Civil.

Esta análise objetiva, prima facie, identificar os elementos estruturais (requisitos de aplicabilidade, momento, limites etc.) e os fundamentos de aplicabilidade da teoria sob menção, inseridos nos mencionados projetos de leis.

Indispensável ressaltar, desde já, que dos três projetos de lei acima citados, o que criava o denominado Código de Processo Civil Coletivo foi arquivado pelo Plenário da Comissão de Constituição e Justiça e de Cidadania da Câmara dos Deputados, por maioria de votos do colegiado. Contudo, permanece o interesse científico em sua análise, diante do conteúdo expresso em seu texto, conforme especificado no parágrafo anterior.

O Projeto de Lei $3.015 / 2008^{504}$ foi o primeiro a propor a inserção da teoria da dinamização do ônus da prova no direito processual civil brasileiro. Objetiva alterar a redação do artigo 333 da Lei $n^{\circ}$ 5.869, de 11 de janeiro de 1973, ou seja, do Código de Processo Civil vigente, facultando ao juiz, diante da complexidade do caso, estabelecer a incumbência do ônus da prova de acordo com o caso concreto.

504 O Projeto de Lei 3.015/2008 é da autoria do Deputado Federal, representante do Estado da Paraíba, Manoel Alves da Silva Júnior, à época integrante do PSB/PB. Foi apresentado à Mesa da Câmara dos Deputados, em 13 de março de 2008, tendo sido remetido, conforme determina o trâmite regimental, à Comissão de Constituição e Justiça e de Cidadania - CCJC - da citada Casa de Leis. Em 01 de abril de 2008, pela referida CCJC, foi designado Relator o Deputado Federal Leonardo Picciani do PMDB/RJ. Por 05 (cinco) sessões ordinárias, contadas a partir de 03 de abril de 2008, o prazo ficou aberto para recebimento de emendas ao Projeto sob enfoque, prazo este encerrado em 14 de abril do mesmo ano sem que tivesse sido apresentada sequer uma emenda. Em 17 de dezembro de 2008 foi designado novo Relator do Projeto de Lei, o Deputado Federal Flávio Dino do PCdoB/MA, pela CCJC. Em 21 de dezembro de 2010, ou seja, mais de dois anos depois, o relator devolveu o Projeto à Comissão, sem parecer conclusivo. Nos presentes dias, o projeto aguarda que a CCJC designe novo relator. 
Na literalidade, propõe introduzir ao citado artigo, mais um parágrafo, o segundo, com a seguinte redação: $\S 2^{o}$ - É facultado ao juiz, diante da complexidade do caso, estabelecer a incumbência do ônus da prova de acordo com o caso concreto.

O autor do Projeto justifica sua apresentação afirmando, em síntese, que a existência de regras pré-fixadas de distribuição do ônus da prova dificulta a produção da prova e acabam por fazer com que a parte arque com as consequências de não ter provado fato de difícil elucidação. Sustenta ainda que a teoria da distribuição dinâmica do ônus da prova já é aplicada pela jurisprudência e representa a aplicação prática dos princípios constitucionais da adequação, da cooperação e da igualdade entre as partes. ${ }^{505}$

Depreende-se do acima exposto que a justificativa do projeto de lei sob análise apresenta maior adequação científica à teoria da dinamização do onus probandi do que propriamente o texto proposto.

O projeto apresenta apenas um único requisito de aplicabilidade da teoria da dinamização do ônus da prova, consistente na complexidade do caso, deixando passar in albis qualquer menção quanto aos demais elementos estruturais da teoria, especificados neste trabalho. ${ }^{506}$

$\mathrm{Na}$ verdade, a complexidade que configura o requisito de aplicabilidade da teoria diz respeito à complexidade na produção da prova, conforme afirmado e analisado anteriormente. $^{507}$

\footnotetext{
${ }^{505}$ Devida a transcrição integral da justificativa do PL 3.015/2008, apresentada por seu autor: "As regras de ônus da prova são regras de julgamento, ou seja, são aplicadas no momento em que o juiz vai julgar. Não estabelecem disposições a ser cumpridas pelas partes, não dizem quem deve produzir a prova e sim, quem arca com as consequências da não produção da prova. A norma presente no art. 333 do CPC - Código de Processo Civil estabelece que o ônus da prova é estático: do autor, com relação ao que alega, e do réu, em relação a fato extintivo, modificativo ou impeditivo do direito do autor. Contudo, a doutrina processualista desenvolveu a teoria da distribuição dinâmica do ônus da prova ou das cargas probatórias dinâmicas que defende que o ônus da prova deve ser distribuído de acordo com as peculiaridades do caso concreto. De fato, regras previamente estabelecidas, em muitos casos, dificultam a produção da prova e acabam por fazer com que a parte arque com as consequências de não ter provado fato de difícil elucidação. A possibilidade de facultar ao juiz, diante da complexidade do caso, restabelecer as regras de ônus da prova consagra a referida teoria, já aplicada pela jurisprudência, e representa aplicação prática dos princípios constitucionais da adequação, da cooperação e da igualdade entre as partes. Diante do exposto, justifico a presente proposição.". ${ }^{506}$ Cf. Título III, seção 3.2.2.1 - Requisitos de aplicabilidade da dinamização do ônus da prova.

${ }^{507}$ Cf. Título III, seção 3.2.2.1.5 - Prova complexa.
} 
A expressão consignada no projeto, "complexidade do caso", não guarda rigor técnico-jurídico, sendo ambígua, pois o vocábulo "caso" pode ser interpretado como causa, sinônimo de demanda. Em efeito, complexidade da demanda não é sinônimo de complexidade na produção da prova, possuindo enquadramento técnico-jurídico diverso.

Ademais, insta reiterar que a complexidade da demanda não é requisito de aplicabilidade da teoria sob enfoque, pois uma causa considerada simples, pode também demandar uma distribuição dinâmica do ônus da prova, diante da desigualdade das partes, da dificuldade na produção da prova pelo respectivo onerado, enfim, pela necessidade de aplicação dos princípios da igualdade e cooperação entre as partes. ${ }^{508}$

O conteúdo da justificativa do projeto apresenta como fundamentos de aplicabilidade da teoria da dinamização os princípios da adequação, da cooperação e da igualdade entre as partes.

Diante disto, é possível afirmar que o grande mérito deste projeto de lei, ainda em trâmite, consiste na tentativa de introdução em nosso sistema processual civil, de forma positivada, mesmo que com redação equivocada, da teoria da dinamização do ônus da prova, abrindo ainda mais as portas para sua aplicação e consequente possibilidade de sedimentação e aperfeiçoamento. ${ }^{509}$

\footnotetext{
${ }^{508}$ Essa diferença foi analisada na seção 3.2.2.1.5. Demonstrando a dificuldade em conceituar complexidade da causa, em âmbito de juizados especiais cíveis, a matéria foi objeto de discussão, edição e ratificação de Enunciado pelo XXVII Fórum Nacional de Juizados Especiais - FONAJE/2010: Enunciado 54 - A menor complexidade da causa para a fixação da competência é aferida pelo objeto da prova e não em face do direito material.

${ }^{509} \mathrm{O}$ projeto sob enfoque perderá sua finalidade com a aprovação do Projeto de Lei do Senado 166/2010, que visa instituir o novo Código de Processo Civil.
} 


\subsection{PROJETO DE LEI N 5.139/2009}

Com o objetivo de modernizar a legislação relativa à tutela coletiva, ${ }^{510}$ sendo este um dos objetivos do segundo pacto republicano e levando em consideração as profundas transformações sociais ocorridas desde a edição da Lei da Ação Civil Pública em 1985, foi elaborado o Projeto de Lei $n^{\circ} 5.139 / 2009$, por uma comissão especial do Ministério da Justiça formada por renomados juristas. Entretanto, antes de ser apresentado à Mesa da respectiva Casa de Leis, o governo modificou o anteprojeto, excluindo a aplicação da Ação Civil Pública às demandas de natureza tributária e quanto aos benefícios previdenciários e FGTS. Oportunamente, o Supremo Tribunal Federal declarou que a proibição do uso da Ação Civil Pública nessas questões é constitucional.

O Projeto de Lei 5.139/2009, ${ }^{511}$ que visava essencialmente disciplinar a ação civil pública para a tutela de interesses difusos, coletivos ou individuais homogêneos, foi o segundo a propor a inserção da teoria da dinamização do ônus da prova no direito processual civil brasileiro, sendo, todavia, diversamente do projeto acima citado, criado por renomados juristas que avalizaram todas as propostas de modificação ali inseridas, dentre eles Ada Pellegrini Grinover. ${ }^{512}$

\footnotetext{
${ }^{510}$ O microssistema coletivo é formado pela Lei de Ação Civil Pública, Código de Defesa do Consumidor, Estatuto da Criança e do Adolescente, Estatuto do Idoso, Estatuto do Índio, Lei de Improbidade Administrativa, Mandado de Segurança Coletivo, Ação Popular, Mandado de Injunção, Ação Direta Interventiva, Ação de Impugnação de Mandato Eletivo. Contudo, a LACP e o CDC são os instrumentos legais mais utilizados no dia-a-dia forense.

${ }^{511}$ O Projeto de Lei 5.139/2009, de autoria do Poder Executivo visava disciplinar a ação civil pública para a tutela de interesses difusos, coletivos ou individuais homogêneos, além de conferir outras providências. Foi apelidado de Projeto do "Código de Processo Civil Coletivo", pois oriundo do Anteprojeto do Código Brasileiro de Processo Coletivo. O Projeto de Lei sob enfoque foi apresentado à Mesa do Congresso Nacional em 29 de abril de 2009, sendo-lhe conferido regime de tramitação prioritário, tendo sido remetido, conforme determina o trâmite regimental, à Comissão de Constituição e Justiça e de Cidadania - CCJC - da Câmara dos Deputados. Em 06 de maio de 2009, pela referida CCJC, foi designado Relator o Deputado Federal Antonio Carlos Biscaia do PT/RJ. Inicialmente foram apresentadas 11 (onze) emendas. Em 15 de setembro de 2009, o Relator apresentou parecer, opinando pela sua aprovação e das emendas $n^{\circ} 02,04$ a 07 , 09 e 10 apresentadas na Comissão. Seguindo o trâmite, foi aberto prazo para apresentação de emendas ao substitutivo. Foram apresentadas 100 (cem) emendas ao substitutivo. A matéria recebeu ainda 03 (três) substitutivos da relatoria da CCJC. Por fim, cumprido todo o trâmite regimental, o Projeto foi arquivado na respectiva Comissão, em 17 de março de 2010, sendo vencedor o voto do Deputado José Carlos Aleluia (DEM/BA), o qual opinou, no mérito, pela rejeição do PL-5139/09.

512 O Ministério da Justiça, através da Portaria no 2.481/2008, instituiu uma Comissão Especial com o objetivo de formular uma proposta de modernização da tutela coletiva, com os seguintes integrantes: como presidente, Rogério Favreto, Secretário de Reforma do Poder Judiciário; como responsável pela relatoria, Luiz Manoel Gomes Junior; Ada Pellegrini Grinover; Alexandre Lipp João; Aluisio Gonçalves de Castro Mendes; André da Silva Ordacgy; Anizio Pires Gavião Filho; Antonio Augusto de Aras; Antonio Carlos
} 
O Projeto de Lei sob análise, de forma inovadora e muito mais efetiva que o projeto de Lei $n^{\circ} 3.015 / 2008$, objetivava introduzir a teoria da dinamização do ônus da prova em nosso sistema processual civil positivado, por intermédio do seu artigo 20, incisos IV a VII, que recebeu significativas emendas durante o trâmite legislativo. ${ }^{513}$

Como advertido anteriormente, por decisão do Plenário da Comissão de Constituição e Justiça e de Cidadania da Câmara dos Deputados, em 17 de março de 2010, o Projeto de Lei foi definitivamente arquivado, por maioria de votos, após parecer do Deputado José Carlos Aleluia. ${ }^{514}$ Não obstante, seu texto continha conteúdo relevante para este estudo.

O projeto apresentava dois requisitos de aplicabilidade da teoria da dinamização do ônus da prova: a) a maior facilidade de uma das partes na demonstração dos fatos e, b) a detenção, por uma das partes, de conhecimentos técnicos ou informações específicas sobre os fatos.

Oliveira Gidi; Athos Gusmão Carneiro; Consuelo Yatsuda Moromizato Yoshida; Elton Venturi; Fernando da Fonseca Gajardoni; Gregório Assagra de Almeida; Haman de Moraes e Córdova; João Ricardo dos Santos Costa; José Adonis Callou de Araújo Sá; José Augusto Garcia de Souza; Luiz Philippe Vieira de Mello Filho; Luiz Rodrigues Wambier; Petrônio Calmon Filho; Ricardo de Barros Leonel; Ricardo Pippi Schmidt e Sérgio Cruz Arenhart.

513 Projeto de Lei 5.139/2009, acrescido das respectivas emendas. Art. 20. Não obtida a conciliação ou quando, por qualquer motivo, não for utilizado outro meio de solução do conflito, o juiz, fundamentadamente: [...] IV - distribuirá a responsabilidade pela produção da prova, levando em conta os conhecimentos técnicos ou informações específicas sobre os fatos detidos pelas partes ou segundo a maior facilidade em sua demonstração, podendo atribuir o ônus da prova ou o seu custeio ao réu; V - poderá ainda distribuir essa responsabilidade segundo os critérios previamente ajustados pelas partes, desde que esse acordo não torne excessivamente difícil a defesa do direito de uma delas; VI - poderá, a todo momento, até o saneamento do processo, rever o critério de distribuição da responsabilidade da produção da prova e das despesas com seu custeio, diante de fatos novos, observado o contraditório e a ampla defesa, sendo vedada a inversão do ônus da prova na sentença; VII - esclarecerá as partes sobre a distribuição do ônus da prova; e [...]. (transcrição ipsis litteris).

${ }^{514}$ Insta colacionar parte do conteúdo do parecer vencedor, da lavra do Deputado José Carlos Aleluia: "A proposta cria processo em que o réu recebe tratamento desigual de um juiz que terá liberdade para tomar partido sempre e somente em favor do autor, inclusive alterando a ordem das fases processuais, e concedendo liminares (e antecipações de tutela) sem que o autor as tenha pedido e sem que tenha sido dada oportunidade de defesa ao réu. [...] Em suma, a proposição não resolve os problemas do modelo atual das ações civis públicas, gera insegurança jurídica em escala inimaginável, fomenta a ida irresponsável a juízo para a defesa de interesses coletivos sem qualquer garantia de que esses interesses estejam sendo bem representados, e expõe toda a economia, toda a sociedade e todos os indivíduos ao risco de se tornarem réus numa ação em que serão tratados como párias, do começo ao seu longínquo fim.”. (transcrição ipsis litteris). 
Previa a possibilidade das partes, prévia e consensualmente, estabelecer critérios para a distribuição do ônus da prova, desde que não se tornasse excessivamente difícil a defesa do direito de uma delas.

Quanto ao momento para a aplicação da dinamização, o projeto foi substancialmente modificado, por intermédio de uma emenda, passando a disciplinar que o juiz poderia, até o saneamento, rever o critério de distribuição da responsabilidade da produção da prova. No final do inciso, o legislador vedada a inversão do ônus da prova, pelo magistrado, na sentença.

Vê-se, assim, que o legislador pátrio utilizou, originariamente e equivocadamente, como sinônimas, as expressões "distribuição do ônus da prova" e "distribuição da responsabilidade da produção da prova”. Melhor seria se tivesse adotado unicamente a primeira expressão, já consagrada em doutrina e jurisprudência, diminuindo assim a margem de dubiedade exegética. ${ }^{515}$

Estabelecia ainda, no inciso VII do artigo 20, de forma expressa, o dever de informação do juiz quanto à distribuição do ônus da prova.

Na justificativa do projeto, apesar de não consignar expressamente a introdução da dinamização do onus probandi, o Ministro da Justiça registrou que a disciplina do ônus da prova estaria voltada à produção de quem estivesse mais próximo dos fatos e tivesse capacidade de produzi-las, objetivando maior efetividade.

\footnotetext{
515 Importante consignar o equívoco científico-técnico-jurídico de grande monta, irreversível em âmbito doutrinário, constante dos Comentários e observações feitos no bojo do projeto: "Permite ao juiz distribuir e rever a responsabilidade pela produção das provas requeridas pelas partes, bem como a determinar, de ofício, a realização de outras provas que entender cabível. O dispositivo não cuida de inversão de ônus da prova (que é regra de julgamento), mas de responsabilidade pela produção da prova. Ele permite ao juiz submeter o requerido a produzir, às suas expensas, provas contrárias ao seu interesse, que foram requeridas pelo autor coletivo para provar fatos constitutivos do direito alegado na inicial, tudo em prol da alegada função social do Judiciário de resolver conflitos coletivos.”. Como afirmado anteriormente, é impossível dividir um fenômeno indivisível como o ônus da prova. Como o legislador afirmava que não se tratava de regra de julgamento e sim de responsabilidade na produção da prova, qual seria a consequência para a parte que não a produzisse? O legislador não deu resposta, nem conseguiria.
} 
Por fim, não resta dúvida que a redação do inciso IV do artigo 20, conferida pelo substitutivo apresentado pelo relator, introduzia a teoria da dinamização do ônus probatório no arcabouço legal pátrio, ao facultar ao juiz, expressamente, distribuir o ônus da prova às partes, diante da facilidade na demonstração da prova ou diante de conhecimentos técnicos ou especificidades sobre os fatos. 


\subsection{PROJETO DE LEI Nº 166/2010}

Por iniciativa do Senado Federal, foi instituída uma comissão de juristas, através do Ato $n^{\circ} 379$ de 2009, da lavra do Presidente da referida Instituição, visando à elaboração de um anteprojeto do novo Código de Processo Civil Brasileiro. A comissão de juristas foi nomeada no final do mês de setembro de 2009, incumbindo sua presidência ao Ministro Luiz Fux, do Superior Tribunal de Justiça, e sua relatoria à jurista Teresa Arruda Alvim Wambier. ${ }^{516}$

A comissão teve por desafio criar um anteprojeto de um novo Código de Processo Civil que conseguisse resgatar a crença no judiciário e tornar realidade a promessa constitucional de uma justiça pronta e célere. Objetivou, assim, garantir que o novo Código privilegiasse a simplicidade da linguagem e da ação processual, a celeridade do processo e a efetividade do resultado da ação, além do estímulo à inovação e à modernização de procedimentos, garantindo o respeito ao devido processo legal.

Em 08 de junho de 2010, a Presidência do Senado comunicou ao Plenário da Casa o recebimento do Anteprojeto de Código de Processo Civil, fixando o calendário de tramitação do Projeto de Lei do Senado n 166/2010, o qual recebeu, ao final, 106 (cento e seis) emendas.

O Projeto sob menção é o terceiro a propor a inserção da teoria da dinamização do ônus da prova no direito processual civil brasileiro, sendo, como o projeto anteriormente analisado, idealizado por juristas que gozam de altíssima credibilidade na comunidade jurídica nacional, que instituíram e avalizaram todas as propostas de modificação ali inseridas.

O Projeto do novo Código de Processo Civil Brasileiro apresentado pela Comissão citada à Presidência do Senado previa, no Título VII, Capítulo I, que disciplinava as

\footnotetext{
${ }^{516}$ A referida comissão foi integrada ainda pelos seguintes juristas: Adroaldo Furtado Fabrício; Benedito Cerezzo Pereira Filho; Bruno Dantas; Elpídio Donizetti Nunes; Humberto Theodoro Junior; Jansen Fialho de Almeida; José Miguel Garcia Medina; José Roberto dos Santos Bedaque; Marcus Vinicius Furtado Coelho e Paulo Cezar Pinheiro Carneiro.
} 
disposições gerais quanto ao tema das provas, a inserção da teoria da dinamização do ônus da prova no direito positivo pátrio através do artigo 262. ${ }^{517}$ O Senador Adelmir Santana, propôs uma Emenda ao citado Projeto de Lei, que levou o $\mathrm{n}^{\circ} 31$, que pugnava pela supressão do artigo 262, ou seja, pelo total restabelecimento do teor do artigo 333 e incisos do CPC atual. Esta emenda foi rejeitada em sessão plenária do dia 15 de dezembro de 2010, que aprovou o substitutivo da lavra do Senador Valdir Pereira, Relator-Geral do Projeto sob menção. ${ }^{518}$

Em efeito, em relação à proposta original, da lavra da Comissão de juristas, houve apenas mudanças nos números dos artigos que disciplinam a matéria ora analisada, bem como do capítulo, título e livro, mantendo-se integralmente os respectivos conteúdos. Assim, daqui por diante, trataremos do teor do Projeto de Lei ${ }^{\circ} 166 / 10$, já aprovado pelo Senado.

O Projeto de Lei aprovado, em seu artigo 357, incisos I e II, manteve como critério geral, abstrato e prévio, a distribuição rígida do ônus da prova da forma como conhecida e vigente no atual Código de Processo Civil (artigo 333, incisos I e II), ou seja, ao autor incumbe o ônus da prova quanto ao fato constitutivo de seu direito e, ao requerido, o ônus da prova quanto à existência de fato impeditivo, modificativo ou extintivo do direito do autor.

\footnotetext{
${ }^{517}$ PLS 166/10. Redação original. Artigo 262. Redação do Substitutivo aprovado pelo Senado em 15.12.10. Livro II. Processo de Conhecimento e Cumprimento de Sentença. Título I. Do Procedimento Comum. [...] Capítulo XI. Das Provas. Seção I. Das Disposições Gerais. Artigo 358. Considerando as circunstâncias da causa e as peculiaridades do fato a ser provado, o juiz poderá, em decisão fundamentada, observado o contraditório, distribuir de modo diverso o ônus da prova, impondo-o à parte que estiver em melhores condições de produzi-la. $\S 1^{\circ}$ Sempre que o juiz distribuir o ônus da prova de modo diverso do disposto no art. 357, deverá dar à parte oportunidade para o desempenho adequado do ônus que lhe foi atribuído. $\S 2^{\circ} \mathrm{A}$ inversão do ônus da prova, determinada expressamente por decisão judicial, não implica alteração das regras referentes aos encargos da respectiva produção. (transcrição ipsis litteris).

${ }_{518}$ Importante colacionar a íntegra da justificativa da Emenda no 31 e de sua rejeição, conforme consta do parecer levado à votação pelo Relator-Geral do Projeto de Reforma do Código de Processo Civil Brasileiro, Senador Valter Pereira: "Emenda $n^{\circ} 31$. O Senador Adelmir Santana propõe a supressão do art. 262 por considerar que o dispositivo utiliza expressões genéricas, que criam benefícios excessivos sob o pretexto de eliminar desigualdades. Para o Senador, o projeto transfere ao magistrado um poder que tem sido prudentemente reservado ao legislador, violando dessa forma os princípios da legalidade e da segurança jurídica, sendo que o atual sistema de distribuição do ônus da prova é mais consentâneo com as garantias do contraditório e da ampla defesa. [...] Rejeitamos a Emenda $\mathrm{n}^{\mathrm{o}} 31$, tendo em vista que a proposta do projeto coaduna-se com a vanguarda do processo civil. As regras sobre a inversão do ônus da prova, transferido à parte que se encontre em melhores condições de produzi-la, de acordo com as circunstâncias da causa e as peculiaridades do fato a ser provado, por meio de decisão fundamentada, com respeito ao contraditório, constituem um inegável avanço no direito processual brasileiro, e seria um retrocesso retirá-las do projeto.". (transcrição ipsis litteris).
} 
Entretanto, o caput do artigo $357^{519}$ trouxe uma modificação significativa, preparando a introdução da teoria da dinamização do ônus da prova, essencialmente efetivada no artigo seguinte, ao consignar uma ressalva ao critério rígido da distribuição do ônus da prova. A mensagem do dispositivo sob comento é a seguinte: o critério de distribuição do ônus da prova é o rígido, contudo, por ato do magistrado, diante de seu poder, poderá ser modificado.

Como anteriormente afirmado, foi através do original artigo 262, modificado pelo substitutivo para o artigo 358, que o Projeto de Lei ora analisado e já aprovado pelo Senado, introduz a teoria da dinamização no direito positivo pátrio. Verdade é que não utiliza a expressão dinamização do ônus da prova, contudo, tal fato torna-se desnecessário diante da redação do caput do artigo em evidência. Esse dispositivo legal confere poderes ao juiz para distribuir de modo diverso o ônus da prova, em relação ao regime tradicional e rígido do ônus da prova, impondo-o à parte que estiver em melhores condições de produzir a prova, diante das circunstâncias da causa e das peculiaridades do fato a ser provado, ou seja, considerando o caso concreto. Esta é uma das principais justificativas e, ao mesmo tempo, fundamento da teoria da dinamização do ônus da prova.

Esse artigo trouxe apenas um requisito de aplicabilidade da teoria da dinamização do ônus da prova, consistente na maior facilidade de uma das partes na demonstração dos fatos em juízo, nas palavras do texto legal, quem estiver em melhores condições de produzir a prova. Dessa forma, delegou ao Estado-juiz, aumentando significativamente seus poderes, diante do caso concreto, a verificação dessa circunstância, sem estabelecer quaisquer outros parâmetros objetivos definidores do que consistiria a circunstância de estar em melhores condições de produzir determinada prova.

Importante retornar à questão da terminologia. Foi afirmado acima que a teoria da dinamização do ônus da prova foi introduzida no corpo do Projeto em análise no texto do artigo 358, que contém dois parágrafos. Em síntese, no caput o legislador introduziu a teoria ao permitir ao juiz distribuir de modo diverso o ônus da prova. No parágrafo

\footnotetext{
${ }^{519}$ PLS 166/10. Texto aprovado pelo Senado em 15.12.10. Artigo 357. O ônus da prova, ressalvados os poderes do juiz, incumbe: I - ao autor, quanto ao fato constitutivo do seu direito; II - ao réu, quanto à existência de fato impeditivo, modificativo ou extintivo do direito do autor. (transcrição ipsis litteris).
} 
primeiro manteve a coerência e utilizou a mesma terminologia, i.e., distribuição de modo diverso do ônus da prova. Não obstante, no parágrafo segundo, o legislador cometeu o mesmo equívoco do artigo $6^{\circ}$, inciso VIII do CDC, ao utilizar a expressão "inversão" do ônus da prova por decisão judicial. Quanto a este equívoco, este trabalho dedicou expressiva análise, através do qual foi demonstrado de forma cabal que "inversão" não é expressão sinônima de dinamização do ônus da prova. ${ }^{520}$

Questão fulcral que restou dúbia neste Projeto de Lei refere-se ao momento para a aplicação da teoria da dinamização do ônus da prova. Não há previsão expressa, como havia no Projeto de Lei 5.139/09, introduzida por uma emenda, que permitia a aplicação da dinamização pelo juiz até o saneamento dos autos, e vedava a modificação do ônus da prova na sentença.

Ao revés, o texto legal do caput e do parágrafo primeiro do artigo 358, pode induzir ao entendimento de que a modificação do ônus da prova deve ocorrer em momento anterior ao ato sentencial. Isso poderá ocorrer diante da ênfase à observância ao contraditório expressa nos citados textos. No caput, registra que o juiz deverá observar o contraditório e no parágrafo primeiro, consigna que o juiz deverá dar à parte oportunidade para o desempenho adequado do ônus que lhe foi atribuído, em ambos os casos, após a distribuição diversa do ônus da prova em relação ao disposto no artigo 357 do mencionado Projeto de Lei. $^{521}$

No parágrafo segundo do artigo 358, o legislador consolida o entendimento do Superior Tribunal de Justiça no sentido de que a "inversão" do ônus da prova não implica inversão das despesas com sua produção. Essa regra é imperfeita, pois traz em seu bojo uma incongruência sistemática e prática. Insta, mais uma vez, recorrer ao método exemplificativo. Duas empresas litigam em uma ação de ressarcimento de danos. Ambas possuem o mesmo potencial econômico-financeiro. No caso concreto, uma delas, a parte requerente pugna pela prova pericial, a qual foi deferida e os respectivos honorários fixados em $\mathrm{R} \$ 15.000,00$ (quinze mil reais). Contudo é a outra parte que possui maiores facilidades na produção da prova. O Estado-juiz, com base no artigo 358 sob enfoque,

\footnotetext{
${ }^{520}$ Cf. Título III, seção 3.2.1.4 - Dinamização versus inversão do ônus da prova.

${ }^{521}$ Cf. Título III, seção 3.2.2.3 et seq. Não é possível a aplicação da dinamização do ônus da prova em momento diverso ao do ato sentencial.
} 
dinamiza o ônus da prova e estabelece que o ônus da produção dessa prova passe a ser da empresa requerida. Pela regra do parágrafo segundo, a situação processual seria a seguinte: a parte autora, que agora não tem mais o ônus da prova, é responsável por pagar a perícia e a parte requerida, após a inversão, passou a sofrer o risco da não produção da prova, pois o ônus da prova, doravante, está sob sua alçada. A priori, exceto o dever de colaboração das partes com o descobrimento da verdade e, derivado desse dever, o de lealdade, nada obriga à parte autora a pagar a perícia. Qual a consequência se ela se mantiver omissa? Em âmbito probatório nenhum, pois o risco da ausência da prova é da parte ex adversa.

O Superior Tribunal de Justiça, em tais situações, firmou posição que foge ao tema do ônus da prova, criando uma presunção judicial e, assim, uma certeza, em desfavor da parte que se omite e não arca com essas despesas.

Estabelece, ainda, o caput do artigo 358 do respectivo Projeto, de forma expressa, que o ato judicial que distribui de forma diversa o ônus da prova, em detrimento ao regime tradicional e rígido, deve ser fundamentado.

Por fim, sem tecer crítica à redação comentada, por não ser este o local adequado e o objetivo desta pesquisa, pode-se afirmar não restar dúvida que o texto legal do artigo 358 do Projeto de Lei que visa instituir o novo Código de Processo Civil Brasileiro, recém aprovado pelo Senado, caso ultrapasse as etapas seguintes do processo legislativo sem modificações, introduzirá a teoria da dinamização do ônus probatório no direito processual civil pátrio, ao facultar ao juiz, expressamente, distribuir o ônus da prova de forma diversa do regime tradicional, diante da facilidade de uma das partes na produção da prova. 


\section{CONCLUSÃO}

O presente trabalhou procurou demonstrar que o critério de distribuição do ônus da prova, eleito e instituído pelo legislador processual de 1973 e vigente até os dias atuais, não se compatibiliza mais com uma grande quantidade de circunstâncias fáticas e jurídicas apresentadas em juízo e vivenciadas em nosso ordenamento.

A dinamicidade das relações sociais e a evolução tecnológica modificam a todo instante as relações jurídicas daí derivadas, influenciando o como provar (meios), o que deve e necessita ser provado (thema probandum), quem pode provar e quem dever sofrer as consequências da ausência de provas (ônus da prova).

Em decorrência, o sistema processual perde em legitimidade ao continuar se servindo de regras absolutamente rígidas e não consegue evoluir no mesmo passo que a sociedade exige. Assim, não se pode considerar moderno um sistema processual no qual a distribuição do ônus da prova é estabelecida exclusivamente de forma prévia e abstrata, i.e., antes dos fatos ocorrerem no mundo real, como se fosse possível prever todas as hipóteses prováveis e plausíveis e enquadrá-las nessa mesma norma jurídica.

Foi possível perceber com clareza que em muitas circunstâncias essa distribuição rígida do ônus da prova aumenta a desigualdade já existente entre as partes, ao invés de equilibrá-la, fecha as portas do Poder Judiciário ao invés de implementar seu livre e amplo acesso, o que compreende o ingresso em juízo, o desenvolvimento e conclusão da demanda em conformidade com o devido processo legal e, como se não bastasse, viola o direito da parte à amplitude probatória ao exigir daquele que tem maior dificuldade a produção de determinada prova e, na outra face, ao permitir e fomentar àquele que poderia realizar a produção dessa prova com maior facilidade uma postura omissiva.

Em efeito, a distribuição do ônus da prova, disciplinada de forma rígida, inflexível, presente em nosso direito processual civil na regra do artigo 333 do $\mathrm{CPC}$, mostra-se imperfeita e inadequada ante a universalidade (necessidade de abranger todas as hipóteses do mundo real) exigida pelo sistema jurídico. Diante disso, em inúmeras situações 
processuais essa regra afronta garantias fundamentais do cidadão brasileiro, ao prevalecer diante do direito à prova, do direito ao acesso à jurisdição, do direito à igualdade e do próprio devido processo legal.

Diante desse cenário, restou demonstrado, a par de toda a dificuldade que o tema apresenta que a dinamização do ônus da prova vem de forma enfática auxiliar o sistema processual nessa necessária evolução, consistindo em um verdadeiro instrumento teórico e prático-jurídico de evolução desse mesmo sistema, no que toca à distribuição do ônus da prova e tudo que diz respeito e circunda o tema.

Afinal, o processo, visto como instrumento, também dever ser, na medida certa, dinâmico, uma vez que só assim poderá adequar-se, imediatamente, aos fatores temporais, territoriais e até mesmos circunstanciais de si exigidos e, em efeito, abstrair-se deste todo o proveito devido e desejado para o alcance de seus fins.

Por outro lado, a própria teoria da dinamização do ônus da prova não tinha recebido de nossos doutrinadores a atenção devida, não tendo sido objeto de pesquisa a sua respectiva sistematização, sendo aplicada pela jurisprudência pátria ora com fulcro na teoría das cargas probatorias dinámicas, ora sob a falsa veste e equivocada denominação de "inversão" do ônus da prova, ora ainda sob justificativas oriundas essencialmente da especialidade de determinado direito material.

Sob esse desafio, o da sistematização, chega-se ao final com uma inabalável convicção: a teoria da dinamização do ônus da prova, ao ser implementada no campo prático, transforma-se em uma ferramenta jurídico-processual que instrumentaliza e potencializa a efetividade da tutela dos direitos materiais através do exercício do poder jurisdicional.

Como pano de fundo, a teoria da dinamização do ônus da prova está estruturada sob uma visão publicista do processo em detrimento a uma visão exclusivamente privatista-liberal que sempre conduziu o pensamento sobre o tema da prova em âmbito geral. Não obstante, pregou-se pelo equilíbrio entre essas duas ideologias, desmistificando o princípio dispositivo que engessa toda a engrenagem do dinamismo processual. 
Ainda nesse viés estrutural, foi utilizada a idéia fecunda da cooperação, que inclui a de solidariedade, dentro do processo e no tocante à produção da prova. Buscou-se dar um enfoque destacado à atividade processual das partes, porém agora dimensionada em uma concepção cooperativista do processo e não individualista do processo.

A visão solidarista de cooperação no âmbito da jurisdição - ter consciência que é um trabalho em comum - e, buscando efetivar seus resultados, impõe, sob a perspectiva do ônus da prova, de forma precípua, que nenhuma das partes possa, legitimamente, se refugiar no interesse individualista da parte onerada. A visão solidarista do encargo de provar, superando a de feição individualista, retira de posição demasiado subalterna valores que merecem ser resgatados, principalmente, a verdade e a justiça.

Quanto ao valor justiça, representa a própria razão existencial da teoria, afinal, esse valor absoluto é o objetivo síntese da jurisdição no plano social, restando indissociável do escopo jurídico, sob pena de descaracterização do sistema processual e da própria jurisdição.

É exatamente essa a idéia central da teoria da dinamização do ônus da prova, i.e., distribuir o ônus da prova com maior justiça, diante do caso concreto, em estrita observância à igualdade proporcional, avaliando e identificando as desigualdades em âmbito de produção de provas para, em seguida, equilibrar, ao máximo, as diferenças que impedem a concretização desse valor absoluto.

Com base nesse suporte teórico, foi possível sistematizar a teoria da dinamização do ônus da prova, adequando-a ao ordenamento jurídico-processual pátrio, sob quatro elementos fundamentais: a) os requisitos objetivos para a sua aplicabilidade; b) o dever de informação do magistrado às partes; c) o momento de sua aplicabilidade e, d) os limites de sua aplicabilidade.

Ao identificar e estabelecer os requisitos objetivos para a aplicação da teoria da dinamização do ônus da prova foram fixados, a contrario sensu, os limites de sua aplicabilidade. A constituição desses requisitos teve ainda por função sistêmica coibir o livre arbítrio do magistrado na aplicação da dinamização, uma vez que estes vinculam sua atividade jurisdicional. 
Em efeito, é equivocada a idéia, e assim restou demonstrado, que a teoria da dinamização concede ilimitados poderes aos magistrados a ponto de lhes permitir que estabeleçam, arbitrariamente, caso a caso, as regras sobre a distribuição do ônus da prova, sob critérios indeterminados e não universais.

Na realidade, após verificar a presença dos requisitos objetivos de aplicabilidade no caso concreto e aplicar a teoria da dinamização do ônus da prova, o magistrado não o faz por livre arbítrio, mas por uma imposição e observância aos ditames constitucionais e sistemáticos. Não age movido pela mera discricionariedade. Age por um verdadeiro poderdever, diante das garantias e direitos fundamentais que envolvem a matéria posta sob análise ao órgão julgador. Assim, o juiz tem o poder-dever de aplicar a teoria da dinamização do ônus da prova, não lhe sendo possível, diante do caso concreto e preenchidos os requisitos objetivos da aplicabilidade, optar pela sua não aplicação e pela adoção do critério tradicional de distribuição do ônus da prova, gerando assim efetivos prejuízos a uma das partes e violando as regras constitucionais e sistêmicas que fundam sua aplicação.

Visto sob o ângulo de um dever e de elemento fundamental da teoria da dinamização, evidenciou-se que o juiz tem o dever de informar às partes, diante do caso concreto, que ele poderá, ao proferir a sentença, aplicar a teoria da dinamização do ônus da prova, de forma fundamentada e, em seguida, utilizar a regra de julgamento pertinente ao ônus objetivo da prova.

O momento adequado para que o julgador exercite esse dever de informação específica, em síntese, é, essencialmente, na fase procedimental do saneamento do procedimento. Como esse dever de informação tem por conteúdo uma advertência de que o Estado-juiz poderá, na sentença, aplicar a teoria da dinamização do ônus da prova, a partir de sua realização, as partes devem envidar todos os esforços para não deixar incertezas nos autos quanto à matéria fática, devendo produzir toda a prova que dispõem, em busca da verdade e em observância ao princípio da cooperação, da boa-fé, da lealdade e probidade processuais. 
O cumprimento desse dever de informação do juiz às partes, além de satisfazer plenamente a exigência constitucional da ampla defesa e do contraditório, a amplia consideravelmente, pois além de informar à parte, dando efetiva ciência de tudo aquilo que ocorre no processo e, particularmente, do que possa a vir acontecer em âmbito de distribuição ônus da prova e respectivas consequências, permite que as partes possam reagir, exercendo todo e qualquer ato pertinente à produção da prova.

Também analisado como um elemento estrutural, portanto essencial, foi demonstrado que o momento de aplicação da teoria da dinamização do ônus da prova é o do ato sentencial. É no ato sentencial que o Estado-juiz irá averiguar e valorar, primeiramente o contexto probatório produzido e, em seguida, realizando exercício intelectivo e técnico-jurídico, verificará e valorará os fatos que restaram provados e os que careceram de demonstração. Além disso, foi amplamente evidenciado durante esta pesquisa que a aplicação da teoria no ato sentencial não fere qualquer garantia fundamental ou princípio constitucional.

Ao revés, sua aplicação em momento diverso ao da sentença, i.e., em decisão anterior e durante o procedimento, é que viola flagrantemente uma série de preceitos de cunho teórico-sistêmicos.

Os principais argumentos que justificam o entendimento sob enfoque são: A. Ignora-se o relevante fato jurídico de que esta teoria está calcada na perspectiva cooperativa-solidarista do processo, tendo ambas as partes o dever de colaborar para o descobrimento da verdade, pois a tese contrária trabalha com a velha perspectiva liberalindividualista. B. A teoria da dinamização do ônus da prova, ao enfatizar o dever de informação do magistrado às partes, quanto a sua aplicação, amplia não só a cientificação dos atos processuais presentes e futuros, quanto o grau de participação das mesmas no processo e, via de consequência, torna absolutamente efetiva a ampla defesa e o contraditório, que significam efetiva ciência e oportunização, o que refuta, definitivamente, o falso argumento da tese contrária de violação a tais princípios imputado à presente teoria. C. A presente teoria não implica determinar à parte que produza prova contra si, pois ao dinamizar o ônus da prova, o magistrado não imputará ao réu o ônus da produção da prova constitutiva do direito do autor e, muito menos, imputará ao autor a produção da prova desconstitutiva lato sensu de seu próprio direito, irá, sim, onerar quem tem mais facilidade 
na produção da prova e desonerar quem tem mais dificuldade em sua produção, respeitando a natureza dos fatos a ser provados: constitutivos e desconstitutivos lato sensu. D. A tese contrária desconsidera a qualificação técnica dos operadores do direito, pois os respectivos profissionais da área jurídica conhecem essas regras de distribuição do ônus da prova e, assim, não seriam surpreendidos pela aplicação da distribuição dinâmica do ônus da prova e seu contexto teórico. E. A tese contrária é extremamente prejudicial à celeridade e efetividade do processo, uma vez que os Tribunais Superiores e Tribunais de Justiça, ao aplicarem a dinamização do ônus da prova, antes de proferir o julgamento do mérito recursal, seriam obrigados a realizar diligências, i.e., a reabrir a instrução probatória, permitindo às partes a produção de provas a ser requeridas perante aquele juízo ad quem, diante desse novo cenário de distribuição do ônus da prova para, posteriormente, proferir o julgamento definitivo do recurso de apelação, sem contar que essa decisão de dinamização antes da sentença daria ensejo a agravos retido e de instrumento, contribuindo assim com a morosidade procedimental e a eternização das lides, sem contar com a insegurança jurídica ao instituir verdadeira fase probatória obrigatória em segundo grau. F. Ao acatar a tese combatida, estaria o magistrado repartindo o ônus da prova baseado em razões de verossimilhança do caso concreto, formando um convencimento ou anterior ou paralelo à repartição do referido ônus, tornando impossível saber onde termina o convencimento e onde começa a repartição do ônus da prova.

Como se não bastasse, como não incidiria o fenômeno da preclusão pro iudicato, poderia tal decisão, a medida do desenvolvimento do procedimento, ser aplicada mais de uma vez, gerando uma total insegurança e balbúrdia processual. O processo, assim, retroagiria à indesejada e ultrapassada fase do subjetivismo na qual se permitia compará-lo a um jogo cujo resultado era absolutamente imprevisível.

O entendimento sustentado por alguns autores no sentido de que a atual inversão e a dinamização do ônus da prova devem ser aplicadas em momento anterior ao da sentença, deve ser objeto de uma profunda e séria futura pesquisa, uma vez que esse caminho, além do acima dito, estabelece uma ruptura com o dogma do ônus da prova, pois foi demonstrado não ser possível harmonizar teoricamente esse entendimento com o ônus da prova objetivo. Quem defende que qualquer espécie de modificação do ônus da prova, mesmo que com autorização do legislador, possa ser realizada em momento diverso ao do ato sentencial não pode, em efeito, sustentar, dentro dos rigores teórico-jurídicos, que ônus 
da prova é regra de julgamento. E, por sua vez, estará afirmando que o fenômeno do ônus da prova só tem uma face, a subjetiva.

Ainda resta afirmar, a título de conclusão, que a teoria da dinamização do ônus da prova não altera a predominância teórico-conceitual do aspecto objetivo do dogma do ônus da prova. Em efeito, não tem por objeto a distribuição direta da responsabilidade da produção da prova, como queria o Projeto de Lei que instituía o Código de Direito Processual Coletivo, já arquivado. Por outro lado, distribui incisivamente a responsabilidade da inércia probatória entre ambas as partes. Ainda, a teoria da dinamização não altera a autonomia conceitual de ônus processual.

O presente trabalho demonstrou de forma cabal que a teoria da dinamização do ônus da prova não só pode e deve ser aplicada de lege lata, como efetivamente o é pela jurisprudência pátria.

A principal justificativa científico-jurídica para a aplicação da teoria da dinamização de lege lata consiste na necessidade de solucionar, em âmbito teóricojurídico, a tensão entre normas jurídicas, entre princípios e regras, i.e., solucionar o conflito existente entre determinadas garantias fundamentais constitucionais e o direito positivado processual, no que diz respeito ao dogma da distribuição do ônus da prova e suas consequências diretas e indiretas, que afligem tanto o próprio direito processual quanto o direito material.

Assim, as garantias fundamentais constitucionais à inafastabilidade da jurisdição, da igualdade entre as partes, o direito constitucional à prova e ao devido processo legal impõem ao magistrado sua efetiva aplicação diante da análise detida de cada caso concreto.

Por fim, visando eliminar dubiedades e enraizar sua aplicação em nosso sistema jurídico, diante da nossa cultura e do nosso culto ao positivismo, seria oportuna uma modificação legislativa na disciplina da distribuição do ônus da prova inserindo no direito positivo processual, ao lado da distribuição rígida, a distribuição dinâmica e, assim, a teoria da dinamização do ônus da prova, mas sem perder a consciência jurídica que ambos se referem à regra de julgamento. 


\section{REFERÊNCIAS}

ALMEIDA, João Batista de. A proteção jurídica do consumidor. São Paulo: Saraiva, 2002.

AMODIO, Ennio. Diritto al silenzio o dovere di collaborazione? Rivista di Diritto Processuale, Padova, CEDAM, v. 29, série 2, p. 408-419, anno 1974.

ARAGÃO, Egas Dirceu Moniz de. Regras de prova no código civil. Studi di diritto processuale civile in onore di Giuseppe Tarzia. Milano: Giuffrè, 2005. v. 1. p. 863-885.

Comentários ao código de processo civil. 9. ed. rev. e atual. Rio de Janeiro:

Forense, 2000. v. 2.

Exegese do Código de Processo Civil. Rio de Janeiro: Editora Aide, 1992.

ARAZI, Roland. La prueba en el proceso civil. 2. ed. actualizada y aumentada. Buenos Aires: Ediciones La Rocca, 1998.

et al. Debido proceso: realidad y debido proceso: el debido proceso y la prueba. Santa Fé: Rubinzal-Culzoni Editores, 2003.

ARENHART, Sérgio Cruz. Perfis da tutela inibitória coletiva. São Paulo: Revista dos Tribunais, 2003.

. A verdade e a prova no processo civil. Revista de Derecho Procesal, Madrid, v. 7, p. 71-109, 2005.

. Ônus da prova e sua modificação no processo civil brasileiro. In NEVES, Daniel Amorim Assumpção. Provas: aspectos atuais do direito probatório. São Paulo: Método, 2009. p. 329-365.

; MARINONI, Luiz Guilherme. Prova. São Paulo: Revista dos Tribunais, 2009.

AROCA, Juan Montero. La prueba en el proceso civil. 2. ed. Madrid: Editoral Civitas S.A., 1998. 
ASSIS, Araken de. Manual dos Recursos. 2. ed. rev., atual. e ampl. São Paulo: Revista dos Tribunais, 2008.

AUGENTI, Giacomo Primo. L`onere della prova. Roma: Società Editrice del Foro Italiano, 1932.

ÁVILA, Humberto Bergmann. Teoria dos princípios: da definição à aplicação dos princípios jurídicos. 10. ed. ampl. atual. São Paulo: Malheiros, 2009.

BARBERIO, Sérgio José. Cargas probatorias dinámicas: qué debe probar el que no puede probar? In PEYRANO, Jorge Walter. Cargas probatorias dinámicas. 1. reimp. Santa Fé: Rubinzal-Culzoni Editores, 2008. p. 99-107.

BARBOSA MOREIRA, José Carlos. Reformas processuais e poderes do juiz. In Temas de direito processual: 8. série. São Paulo: Saraiva, 2004. p. 53-67.

Prueba y motivación de la sentencia. In Temas de direito processual: 8. série. São Paulo: Saraiva, 2004. p. 107-115.

Julgamento e ônus da prova. In Temas de direito processual: 2. série. 2. ed. São Paulo: Saraiva, 1988. p. 73-82.

. O problema da "divisão do trabalho" entre juiz e partes: aspectos terminológicos. In __. Temas de direito processual: 4. série. São Paulo: Saraiva, 1989. p. 35-44.

Os poderes do juiz na direção e na instrução do processo. In Temas de direito processual: 4. série. São Paulo: Saraiva, 1989. p. 45-66.

. La igualdad de las partes en el proceso civil. In . Temas de direito processual: 4. série. São Paulo: Saraiva, 1989. p. 67-81.

As presunções e a prova. In . Temas de direito processual: 1. série. 2. ed. São Paulo: Saraiva, 1988. p. 55-71.

. Reflexões sobre a imparcialidade do juiz. In 7. série. São Paulo: Saraiva, 2001. p. 19-30. Temas de direito processual: 
abril-junho 1984.

O juiz e a prova. Revista de Processo, São Paulo, RT, ano 9, n. 35, p. 178-184,

BECÚ, Ricardo Zorraquín; MOUCHET, Carlos. Introducción al derecho. Buenos Aires: Librería Editorial Depalma, 1953.

BEDAQUE, José Roberto dos Santos. Poderes instrutórios do juiz. 3. ed. rev., atual. e ampl. São Paulo: Revista dos Tribunais, 2001.

. Direito e processo. 4. ed. rev. e ampl. São Paulo: Malheiros, 2006.

. Efetividade do processo e técnica processual. São Paulo: Malheiros, 2006.

. Garantia da amplitude de produção probatória. In TUCCI, José Rogério Cruz e. Garantias constitucionais do processo civil. São Paulo: Revista dos Tribunais, 1999. p. 151-189.

BENTHAM, Jeremías. Tratado de las pruebas judiciales. Por Estevan Dumont. Traducido al castellano por José Gomez de Castro. Madrid: Imprensa de Tomas Jordan, 1835. v. 1.

Tratado de las pruebas judiciales. Escrita em francês por Estevan Dumont. Traducido al castellano por C.M.V. Paris: Bossange Frères, 1825. v. 3.

BESSO, Chiara. La prova prima del processo. Torino: G. Giappichelli Editore, 2004.

BETTI, Emilio. Diritto processuale civile italiano. $2^{\mathrm{a}}$ ed. Roma: Società Editrice del Foro Italiano, 1936.

BIAVATI, Paolo. Il diritto delle prove nel quadro normativo dell unione europea. In CONVEGNO NAZIONALE, $25^{\circ}, 2005$, Cagliari. Le prove nel processo civile: quaderni dell associazione fra gli studiosi del processo civile. Milano: Giuffrè, 2007. p. 91-125.

BUZAID, Alfredo. Do ônus da prova. In . Estudos de direito I. São Paulo: Saraiva, 1972. p. 45-78.

CALAMANDREI, Piero. Derecho procesal civil: estudios sobre el proceso civil. Traducción Santiago Sentís Melendo. Buenos Aires: EJEA, 1962. v. 3. 
CÂMARA, Alexandre Freitas. Juizados especiais cíveis estaduais e federais: uma abordagem crítica. Rio de Janeiro: Lumen Juris, 2004.

CAMBI, Eduardo. A prova civil: admissibilidade e relevância. São Paulo: Editora Revista dos Tribunais, 2006.

Neoconstitucionalismo e neoprocessualismo. Panóptica, Vitória, ano 1, n. 6, fevereiro 2007, p. 1-44. Disponível em: 〈http//:www.panoptica.org>. Acesso em: 29 agosto 2010.

CAMPO, Hélio Márcio. O princípio dispositivo em direito probatório. Porto Alegre: Livraria do Advogado, 1994.

CANOTILHO, José Joaquim Gomes. Estudos sobre direitos fundamentais. Coimbra: Coimbra Editora, 2004.

Direito constitucional. 5. ed. Coimbra: Almedina, 1991.

Direito constitucional e teoria da constituição. 7. ed. 4. reimpr. Coimbra: Almedina, 2003.

CAPONI, Remo. Note in tema di poteri probatori delle parti e del giudice nel processo civile tedesco dopo la riforma del 2001. In CONVEGNO NAZIONALE, 25, 2005, Cagliari. Le prove nel processo civile: quaderni dell associazione fra gli studiosi del processo civile. Milano: Giuffrè, 2007. p. 265-301.

CAPPELLETTI, Mauro. La testimonianza della parte nel sistema dell oralità. Milano: Giuffrè, 1962.

Juízes legisladores? Tradução Carlos Alberto Alvaro de Oliveira. Reimp. Porto Alegre: Sergio Antonio Fabris Editor, 1999.

. Processo e ideologie. Bologna: Il Mulino, 1969.

La oralidad y las pruebas en el proceso civil. Traducción de Santiago Santis Melendo. Buenos Aires: EJEA, 1972. 
Efficacia di prove illegittimamente ammesse e comportamento della parte. Studi in onore di Arturo Carlo Jemolo. Milano: Giuffrè, 1963. v. 2. p. 175-202.

CARBONE, Carlos Alberto. Cargas probatorias dinámicas: una mirada al derecho comparado y novedosa ampliación de su campo de acción. In PEYRANO, Jorge Walter. Cargas probatorias dinámicas. 1. reimp. Santa Fé: Rubinzal-Culzoni, 2008. p. 197-228.

CARNACINI, Tito. Tutela giurisdizionale e tecnica del processo. Milano: Giuffrè, 1950.

CARNELUTTI, Francesco. La prueba civil. 2. ed. Buenos Aires: Depalma, 2000. . Sistema di diritto processuale civile. Padova: Cedam, 1936. v. 1 e 2.3 v.

Sistema de derecho procesal. Traducción de Niceto Alcalá-Zamora y Castillo y Santiago Sentís Melendo. Buenos Aires: Uteha, 1944. v. 1.4 v.

Un curioso abbaglio in tema di onere della prova. Rivista di Diritto Processuale, Padova, CEDAM, v. 13, p. 452-455, anno 1958.

CARPES, Artur Thompsen. A prova e participação no processo civil: a dinamização dos ônus probatórios na perspectiva dos direitos fundamentais. 2008. 176 f. Dissertação (Mestrado) - Programa de Pós-Graduação em Direito, Faculdade de Direito, Universidade Federal do Rio Grande do Sul, Porto Alegre.

Apontamentos sobre a inversão do ônus da prova e a garantia do contraditório. In KNIJNIK, Danilo (coord.). Prova judiciária: estudos sobre o novo direito probatório. Porto Alegre: Livraria do Advogado, 2007. p. 27-49.

CARRATTA, Antonio. Funzione dimostrativa della prova: verità del fatto nel processo e sistema probatorio. Rivista di Diritto Processuale, Padova, v. 56, n. 1, p. 73-103, 2001.

CAVALLONE, Bruno. Il giudice e la prova nel processo civile. Padova: CEDAM, 1991.

. Crisi delle "maximen" e disciplina dell instruzione probatoria. Rivista di Diritto Processuale, Padova, CEDAM, v. 31, serie 2, p. 678-707, anno 1976.

Critica della teoria delle prove atipiche. Rivista di Diritto Processuale, Padova, CEDAM, v. 33, serie 2, p. 679-740, anno 1978. 
. Forme del procedimento e funzione della prova (ottant`anni dopo Chiovenda). In CONVEGNO NAZIONALE, $25^{\circ}, 2005$, Cagliari. Le prove nel processo civile: quaderni dell associazione fra gli studiosi del processo civile. Milano: Giuffrè, 2007. p. 29-52.

CENDON, Paolo; ZIVIZ, Patrizia. L'inversione dell`onere della prova nel diritto civile. Rivista Trimestrale di Diritto e Procedura Civile, Milano, Giuffrè, ano 46, n. 3, p. 757796, settembre 1992.

CHIOVENDA, Giuseppe. Instituições de direito processual civil. 2. ed. São Paulo: Edição Saraiva, 1965. v. 2.3 v.

. L’oralità e la prova. Rivista di Diritto Processuale Civile, Padova, La Litotipo Editrice, v. 1, parte 1, p. 05-32, anno 1924.

CHOO, Andrew L-T. Evidence. New York: Oxford University Press, 2006.

CINTRA, Antônio Carlos de Araújo; GRINOVER, Ada Pellegrini; DINAMARCO, Cândido Rangel. Teoria geral do processo. 17. ed. rev. e atual. São Paulo: Malheiros, 2001.

CIPRIANI, Franco. L'avvocato e la verità. In YARSHELL, Luiz Flávio; MORAES, Maurício Zanoide de. (coord.). Estudos em homenagem à professora Ada Pellegrini Grinover. São Paulo: DPJ Editora, 2005. p. 821-826.

COMOGLIO, Luigi Paolo. Le prove civili. $2^{\mathrm{a}}$ ed. Riveduta ed ampliata. Torino: Unione Tipografico-Editrice Torinense, 2004.

CONTE, Mario. Le prove civile. $2^{\mathrm{a}}$ ed. Aggiornata alla legge di riforma del processo civile 18 giugno 2009, n. 69. Milano: Giuffrè, 2009.

CORREIA, Alexandre; SCIASCIA, Gaetano. Manual de direito romano. 6. ed. São Paulo: Revista dos Tribunais, 1988.

COSTA, Mário Júlio de Almeida. História do direito português. 3. ed. Coimbra: Almedina, 2007. 
COUTURE, Eduardo J. Fundamentos del derecho procesal civil. 3. ed. Buenos Aires: Depalma, 1974.

. Estudios de derecho procesal civil: pruebas en materia civil. 3. ed. Buenos Aires: Ediciones Delpalma, 2003.

DALL'AGNOL JÚNIOR. Antônio Janyr. Distribuição dinâmica dos ônus probatórios. Revista dos Tribunais, ano 90, n. 788, p. 92-107, junho 2001.

DELLEPIANE, Antonio. Nova teoria da prova. Tradução Érico Maciel. 2. ed. Rio de Janeiro: Editor José Konfino, 1958.

DAMASKA, Mirjan R. Il diritto delle prove alla deriva. Bologna: Il Mulino, 2003.

I due tipi di Stato e gli scopi del processo. In TARUFFO, Michele; BESSONE, Mario; SILVESTRI, Elisabetta. I metodi della giustizia civile. Padova: CEDAM, 2000. p. 217-265.

I volti della giustizia e del potere: analisi comparatistica del processo. Traduzione di Andrea Giussani e Fabio Rota. Bologna: Il Mulino, 1991.

DENNIS, I. H. The law of evidence. 3rd ed. London: Sweet \& Maxwell, 2007.

DENTI, Vittorio. Processo civile e giustizia sociale. Milano: Edizioni di Comunità, 1971. Le prove nel processo civile. Milano: Giuffrè, 1973.

. Estudios de derecho probatório. Traducción Santiago Sentís Melendo y Tomás A. Banzhaf. Buenos Aires: EJEA, 1974.

L'inversione dell onere della prova: rilievi introduttivi. Rivista Trimestrale di Diritto e Procedura Civile, Milano, Giuffrè, ano 46, n. 3, p. 709-714, settembre 1992.

DINAMARCO, Cândido Rangel. A instrumentalidade do processo. 13. ed. rev. e atual. São Paulo: Malheiros, 2008. 
2009. v. 1 e 3.4 v.

Instituições de direito processual civil. 6. ed. rev. e atual. São Paulo: Malheiros,

Fundamentos do processo civil moderno. 4. ed. rev. e atual. São Paulo: Malheiros, 2001. v. 1.2 v.

Nova era do processo civil. São Paulo: Malheiros, 2003.

DINAMARCO, Pedro da Silva. Ônus processuais: limites à aplicação das conseqüências previstas para o seu não-cumprimento. 2007. 266f. Tese (Doutorado em Direito Processual) - Programa de Pós-Graduação em Direito, Faculdade de Direito, Universidade de São Paulo, São Paulo.

ECHANDÍA, Hernando Devis. Teoría general de la prueba judicial. Buenos Aires: Víctor P. de Zavalía Editor, 1981. v. 1.

EGGLESTON, Richard. Prova, conclusione probatoria e probabilità. Milano: Giuffrè, 2004.

FALCHI, Gianluigi. L'onere della prova nella 'legis actio sacramento in rem`. Roma: Pontificia Universitas Lateranensis, 1972.

FAZZALARI, Elio. La imparcialità del giudice. Rivista di Diritto Processuale, Padova, CEDAM, v. 27, série 2, p. 193-203, anno 1972.

Istituzioni di diritto processuale. $8^{\mathrm{a}}$ ed. Padova: CEDAM, 1996.

FERRARA, Luigi. Il dovere giuridico di lealtà processuale. Il foro italiano, Roma, v. 64, parte 1, p. 586-594, anno 1939.

FERRAZ JÚNIOR, Tércio Sampaio. Introdução ao estudo do direito: técnica, decisão, dominação. 4. ed. São Paulo: Atlas, 2003.

FORNACIARI, Fernando Hellmeister Clito. Ônus da prova no processo civil. 2005. 208 f. Dissertação (Mestrado em Direito Processual) - Programa de Pós-Graduação em Direito, Faculdade de Direito, Universidade de São Paulo, São Paulo. 
FRANCOS, Maria Victoria Berzosa. Los principios inspiradores del futuro proceso civil. In JUNOY, Joan Picó y. Presente y futuro del proceso civil. Barcelona: J.M. Bosch Editor, 1998. p. 27-40.

FURNO, Carlo. Contributo alla teoria della prova legale. Padova: CEDAM, 1940.

GARCÍA GRANDE, Maximiliano. Cargas probatorias dinámicas: ni nuevas, ni argentinas, ni aplicables. [S.1.: s.n.], 2005. Disponível em: <http://www.e-derecho.org.ar/ congresoprocesal/Cargas\%20Probatorias\%20Din\%E1micas\%20_Grande_.pdf $>$. Acesso em: 29 novembro 2010.

GAVAZZI, Giacomo. L`onere: tra la libertà e l’obbligo. Torino: G. Giappichelli, 1970.

GENER, José Luis Murga. Derecho romano clássico II: el processo. Zaragoza: Secretariado de Publicaciones Universidad de Zaragoza, 1980.

GIANTURCO, Luigi. Brevi note sulla teoria dell onere della prova, anche in raporto alle presunzioni, in generale. In GLÜCK, Federico. Commentario alle Pandette. Tradotto ed arricchito di copiose note e confronti col codice civile del regno d'Italia. Livro XXII. Milano: Società Editrice Libraria, 1906.

GIULIANO, Mario. Norma giuridica, diritto soggettivo ed obbligo giuridico. Bologna: Zanichelli, 1952.

GODINHO, Robson Renault. A distribuição do ônus da prova e a Constituição. In NEVES, Daniel Amorim Assumpção. Provas: aspectos atuais do direito probatório. São Paulo: Método, 2009. p. 289-310.

GOLDSCHMIDT, James. Derecho procesal civil. Trad. Leonardo Prieto Castro. Barcelona: Labor, 1936.

GOMES FILHO, Antônio Magalhães. Direito à prova no processo penal. São Paulo: Revista dos Tribunais, 1997.

. Notas sobre a terminologia da prova (reflexos no processo penal brasileiro). In YARSHELL, Luiz Flávio; MORAES, Maurício Zanoide de. (coord.). Estudos em homenagem à professora Ada Pellegrini Grinover. São Paulo: DPJ Editora, 2005. p. 303318.

GONÇALVES, Aroldo Plínio. Técnica processual e teoria do processo. Rio de Janeiro: 
AIDE Editora, 2001.

GRASSELLI, Giorgio. L`instruzione probatoria nel processo civile. Padova: CEDAM, 2009.

GRASSO, Eduardo. La collaborazione nel processo civile. Rivista di Diritto Processuale, Padova, CEDAM, v. 21, série 2, p. 580-609, anno 1966.

GRECO FILHO, Vicente. O conceito de prova. Revista da Faculdade de Direito de Campos. Campos-RJ, ano 5, n. 5, 2004.

. Direito processual civil brasileiro. 20. ed. 2. tir. São Paulo: Saraiva, 2008. v. 1.

Direito processual civil brasileiro. 18. ed. São Paulo: Saraiva, 2007. v. 2.

GRECO, Leonardo. Paradigmas da justiça contemporânea e acesso à justiça. Revista de direito da Unigranrio. [S.l.: s.n.], [19--]. Disponível em:

<http://publicacoes.unigranrio.edu.br/index.php/rdugr>. Acesso em: 07 outubro 2010.

GRINOVER, Ada Pellegrini et al. Código brasileiro de defesa do consumidor: comentado pelos autores do anteprojeto. 6. ed. rev. e atual. até julho de 1999. Rio de Janeiro: Forense Universitária, 1999.

Código brasileiro de defesa do consumidor: comentado pelos autores do anteprojeto. 8. ed. rev., ampl. e atual. com o código civil. Rio de Janeiro: Forense Universitária, 2005.

Liberdades públicas e o processo penal: as interceptações telefônicas. 2. ed. São Paulo: Revista dos Tribunais, 1982.

GUARNIERI, Guerino. Regulamento di giurisdizione: lite temeraria e dovere di lealtà e probità del difensore. Rivista di Diritto Processuale, Padova, CEDAM, v. 43, série 2, p. 201-213, anno 1988.

IRTI, Natalino. Due saggi sul dovere giuridico: obbligo-onere. Napoli: Jovene, 1973.

ITALIA, Vittorio. Le presunzione legali. Milano: Giuffrè, 1999. 
JORGE, Flávio Cheim. Teoria geral dos recursos cíveis. 4. ed. rev., atual. e ampl. São Paulo: Revista dos Tribunais, 2009.

JUNOY, Joan Picó i. Iudex iudicare debet secundum allegata et probata, non secundum conscientiam: storia della erronea citazione di um brocardo nella dottrina tedesca e italiana. Rivista di Diritto Processuale, Padova, CEDAM, v. 62, 2a série, n. 6, p. 1.497-1.518, novdicembre 2007.

I principi del nuovo processo civile spagnolo. Rivista di Diritto Processuale, Padova, CEDAM, v. 58, p. 65-80, anno 2003.

. Il diritto processuale tra garantismo ed efficacia: un dibattito mal impostato. Studi di diritto processual civile in onore di Giuseppe Tarzia. v. 1. Milano: Giuffrè, 2005. p. 213-230.

El derecho a la prueba en proceso civil. Barcelona: Bosch, 1986.

La prueba en el anteproyecto de L.E.C. In Presente y futuro del proceso civil. Barcelona: J.M. Bosch Editor, 1998. p. 239-252.

KARAM, Munir. Princípio distributivo do ônus da prova na organização judiciária romana. Revista de Processo, Revista dos Tribunais, São Paulo, ano 4, n. 24, p. 89-98, outdez 1981.

Ônus da prova: noções fundamentais. Revista de Processo, Editora Revista dos Tribunais, São Paulo, ano 5, n. 17, p. 50-60, jan-mar 1980.

KASER, Max. Direito privado romano. Trad. Samuel Rodrigues e Ferdinand Hämmerle. Lisboa: Fundação Calouste Gulbenkian, 1999.

KAZAZI, Mojtaba. Burden of proof and related issues. The Hague-London-Boston: Kluwer Law International, 1996.

KNIJNIK, Danilo. Os standards do convencimento judicial: paradigmas para o seu possível controle. Revista Forense, Rio de Janeiro, ano 97, n. 353, p. 15-52, jan-fev 2001.

. As (perigosíssimas) doutrinas do "ônus dinâmico da prova" e da "situação de senso comum" como instrumentos para assegurar o acesso à justiça e superar a probatio 
diabolica. In FUX, Luiz; NERY JUNIOR, Nelson; WAMBIER, Teresa Arruda Alvim (Coordenadores). Processo e constituição: estudos em homenagem ao professor José Carlos Barbosa Moreira. São Paulo: Revista dos Tribunais, 2006. p. 942-951.

. Prova judiciária: estudos sobre o novo direito probatório. Porto Alegre: Livraria do Advogado Editora Ltda., 2007.

KOKOTT, Juliane. The burden of proof in comparative and international human rights law (civil and common law approaches with special reference to the american and german legal system). The Hague-London-Boston: Kluwer Law International, 1998.

LEAL, Rosemiro Pereira. Teoria geral do processo: primeiros estudos. 4. ed. Porto Alegre: Síntese, 2001.

LÉPORI WHITE, Inés. Cargas probatorias dinámicas. In PEYRANO, Jorge Walter. Cargas probatorias dinámicas. 1. reimp. Santa Fé: Rubinzal-Culzoni, 2008. p. 35-73.

LESSONA, Carlos. Teoria general de la prueba em derecho civil. 4. ed. Madrid: Instituto Editorial Reus S.A., 1957. v. 1. 5 v.

LEVY, Jean Philippe. La formation de la théorie romaine des preuves. Studi di diritto romano in onore di Siro Solazzi. Napoli: Jovene, [19--]. p. 418-438.

LIEBMAN, Enrico Tullio. Fondamento del principio dispositivo. Rivista di Diritto Processuale, Padova, CEDAM, v. 15, p. 551-565, anno 1960.

LOMBARDO, Luigi. La prova giudiziale: contributo alla teoria del giudizio di fatto nel processo. Milano: Giuffrè, 1999.

. A scienza e il giudice nella ricostruzione del fatto. In CONVEGNO

NAZIONALE, $25^{\circ}$, 2005, Cagliari. Le prove nel processo civile: quaderni dell associazione fra gli studiosi del processo civile. Milano: Giuffrè, 2007. p. 127-172.

LONGO, Giannetto. L`onere della prova nel processo civile romano. Studi in onore di Emilio Betti. Milano: Giuffrè, 1961. v. 3. p. 335-365.

LOPES, João Batista. A prova no direito processual civil. 2. ed. São Paulo: Revista dos Tribunais, 2002. 
LOPES, Maria Elizabeth de Castro. O juiz e o princípio dispositivo. São Paulo: Revista dos Tribunais, 2006.

LUCON, Paulo Henrique dos Santos. Garantia do tratamento paritário das partes. In TUCCI, José Rogério Cruz e. Garantias constitucionais do processo civil. São Paulo: Revista dos Tribunais, 1999. p. 91-131.

LUHMANN, Niklas. Legitimação pelo procedimento. Trad. Maria da Conceição CorteReal. Brasília: Editoria Universidade de Brasília, 1980.

MANDRIOLI, Crisando. Corso di diritto processuale civil. $4^{\mathrm{a}}$ ed. Torino: Giappichelli, 2005. v. $2.3 \mathrm{v}$.

MARINONI, Luiz Guilherme; ARENHART, Sérgio Cruz. Comentários ao código de processo civil. São Paulo: RT, 2005. v. 1.5 v.

; MITIDIERO, Daniel. O projeto do CPC: crítica e propostas. São Paulo: Revista dos Tribunais, 2010.

; Código de processo civil comentado artigo por artigo. 2. ed. rev., atual. e ampl. São Paulo: Revista dos Tribunais, 2010.

. Teoria geral do processo. 5. ed. rev., atual. e ampl. São Paulo: Revista dos Tribunais, 2006. v. 1.

Formação da convicção e inversão do ônus da prova segundo as peculiaridades do caso concreto. In NEVES, Daniel Amorim Assumpção. Provas: aspectos atuais do direito probatório. São Paulo: Método, 2009. p. 255-268.

MARQUES, José Frederico. Manual de direito processual civil. 8. ed. São Paulo: Saraiva, 1985. v. 2.

. Manual de direito processual civil. 7. ed. São Paulo: Saraiva, 1985. v. 3.

MARMELSTEIN, George. O método popperiano aplicado ao direito. Versão preliminar de paper a ser apresentado em curso de doutoramento - Direito, Justiça e Cidadania no século XXI - Universidade de Coimbra, Portugal, janeiro 2009. 
MATOS, Cecília. Ônus da prova no código de defesa do consumidor. 1993. 255 f.

Dissertação (Mestrado em Direito Processual) - Programa de Pós-Graduação em Direito, Faculdade de Direito, Universidade de São Paulo, São Paulo.

McEWAN, Jenny. Evidence and the adversarial process: the modern law. $2^{\text {nd }}$ ed. OxfordEngland: Hart Publishing, 1998.

MELENDO, Santiago Sentis. La prueba: los grandes temas del derecho probatorio. Buenos Aires: EJEA, 1979.

. Naturaleza de la prueba: la prueba es liberdad. Revista dos Tribunais, n. 462, p. 11-22, abril 1974.

MERTON, Robert King. Sociologia: teoria e estrutura. São Paulo: Mestre Jou, 1970.

MICHELLI, Gian Antonio. La carga de la prueba. Traducción Santiago Sentís Melendo. Bogotá-Colombia: Editorial Temis S.A., 2004.

Curso de derecho procesal civil. Traducción Santiago Sentís Melendo. Buenos Aires: EJEA, 1970. v. 2.

MILARÉ, Édis; CASTANHO, Renata. A distribuição do ônus da prova no anteprojeto do código brasileiro de processos coletivos. In GRINOVER, Ada Pellegrini; MENDES, Aluisio Gonçalves de Castro; WATANABE, Kazuo. Direito processual coletivo e o anteprojeto de código brasileiro de processos coletivos. São Paulo: Revista dos Tribunais, 2007. p. 254-262.

MILLER, Arthur R.; KANE, Mary Kay; FRIEDENTHAL, Jack H. Civil procedure. 4nd ed. Hornbook Series. EUA: Thompson West, 2005.

MIRANDA, Francisco Cavalcanti Pontes de. Comentários ao código de processo civil. 3. ed. 3. tir. rev. aument. Atualização legislativa de Sérgio Bermudes. Rio de Janeiro: Forense, 1999. v. 4.

MIRÓ, Horácio G. López. Probar o sucumbir: los tres grados del convencimiento judicial y la regla procesal del onus probandi. Buenos Aires: Abeledo-Perrot, 1998. 
MITIDIERO, Daniel. Colaboração no processo civil: pressupostos sociais, lógicos e éticos. São Paulo: Editora Revista dos Tribunais, 2009.

MONTELEONE, Girolamo. Limiti alla prova di ufficio nel processo civile (cenni di diritto comparato e sul diritto comparato). Rivista di Diritto Processuale, Padova, CEDAM, v. 62, série 2, p. 863-874, luglio-agosto 2007.

MORA, José Ferrater. Dicionário de filosofia. 4. ed. São Paulo: Martins Fontes, 2001.

MORAES, José Rubens de. Sociedade e verdade: evolução histórica da prova. 2008.505 f. Tese (Doutorado em Direito Processual) - Programa de Pós-Graduação em Direito, Faculdade de Direito, Universidade de São Paulo, São Paulo.

MOREIRA, Carlos Roberto Barbosa. Notas sobre a inversão do ônus da prova em benefício do consumidor. Revista de Processo, São Paulo, RT, ano 22, n. 86, p. 295-309, abril-junho 1997.

MORELLO, Augusto Mario. Dificultades de la prueba en procesos complejos. Santa Fé: Rubinzal-Culzoni, 2004.

. El proceso civil moderno. La Plata: Platense, 2001.

La prueba. Tendencias modernas. Buenos Aires: Platense-Abeledo Perrot, 1991.

MURPHY, Peter. Murphy on evidence. $6^{\text {th }}$ ed. London: Blackstone Press Limited, 1980.

NERY JUNIOR, Nelson. Princípios do processo civil na constituição federal. 5. ed. 2. tir. São Paulo: RT, 1999.

; NERY, Rosa Maria de Andrade. Código de processo civil comentado. 11. ed. São Paulo: RT, 2010.

NEVES, Daniel Amorim Assumpção. Provas: aspectos atuais do direito probatório. São Paulo: Método, 2009.

NUNES, Pedro dos Reis. Dicionário de tecnologia jurídica. 12. ed. Rio de Janeiro: Livraria Freitas Bastos S.A., 1993. 
OLIANI, José Alexandre Manzano. O contraditório nos recursos e no pedido de reconsideração. São Paulo: Revista dos Tribunais, 2007.

OLIVEIRA, Carlos Alberto Alvaro de. Poderes do juiz e visão cooperativa do processo. Revista da Ajuris, v. 30, n. 90, p. 55-84, 2003.

. Direito material, processo e tutela jurisdicional. In FUX, Luiz; NERY JUNIOR, Nelson; WAMBIER, Teresa Arruda Alvim (Coordenadores). Processo e constituição: estudos em homenagem ao professor José Carlos Barbosa Moreira. São Paulo: Revista dos Tribunais, 2006. p. 758-778.

. Garantia do contraditório. In TUCCI, José Rogério Cruz e. Garantias

constitucionais do processo civil. São Paulo: Revista dos Tribunais, 1999. p. 132-150.

OLIVEIRA, Gleydson Kleber Lopes de. Apelação no direito processual civil. São Paulo: Revista dos Tribunais, 2009.

PACÍFICO, Luiz Eduardo Boaventura. O ônus da prova no direito processual civil. São Paulo: Revista dos Tribunais, 2000.

PATTI, Salvatore. Prove: disposizioni generali. Bologna: Zanichelli, 1987.

PEYRANO, Jorge Walter. Cargas probatorias dinámicas. 1. reimp. Santa Fé: RubinzalCulzoni, 2008.

. El derecho procesal postmoderno. Revista de Processo, São Paulo, ano 21, n. 81, p. 141-145, jan-março 1996.

El principio de cooperación procesal. [S.l.: s.n.], [19--]. Disponível em:

<http://www.elateneo.org/doctrina-J-W--Peyrano.php>. Acesso em: 29 agosto 2010.

PEYRANO, Marcos L. La teoria de las "cargas probatorias dinámicas" en la flamante ley de enjuiciamiento civil española (ley 1/2000). In PEYRANO, Jorge Walter. Cargas probatorias dinámicas. 1. reimp. Santa Fé: Rubinzal-Culzoni, 2008. p. 179-193.

PICOZZA, Paolo. Ripartizione dell’onere della prova e valore presuntivo della "vetustas" in materia di usi civici. Rivista Giurisprudenza Agraria Italiana, Roma, Ramo Editoriale Degli Agricultori, n. 11, p. 01-11, novembre 1973. 
PIEKENBROCK, Andreas. La ripartizione tra il giudice e le parti nel processo civile tedesco. Annuario di diritto tedesco, Milano, Giuffrè, p. 467-489, anno 2006.

PISANI, Andrea Proto. Lezioni di diritto processuale civile. $5^{\mathrm{a}}$ ed. Napoli: Jovene, 2010. Appunti sulla giustizia civile. Bari: Cacucci Editore, 1982.

POPPER, Karl Raimund. A lógica da pesquisa científica. São Paulo: Cultrix, 1996.

PUGLIESE, Giovanni. La prova nel processo romano classico. Rivista Jus, Milano, Società Editrice Vita e Pensiero, anno 11, v. 3, p. 386-424, settembre 1960.

. Regole e direttive sull'onere della prova nel processo romano per formulas. Scritti giuridici in memoria di Piero Calamandrei, Padova, CEDAM, v. 3, p. 577-617, 1958.

PUNZI, Carmine. Il processo civile: sistema e problematiche. $2^{\mathrm{a}}$ ed. Torino: G. Giappichelli, 2010. v. 2.4 v.

RADBRUCH, Gustav. Introducción a la filosofía del derecho. Trad.Wenceslao Roces. México: Fondo de Cultura Económica, 1951. 192 p.

RAGONE, Álvaro J. Pérez; PRADILLO, Juan Carlos Ortiz. Código procesal civil alemán (ZPO). Colaboradores en el estudio introductorio Hanns Prütting y Sandra De Falco. Montevideo: Fundación Konrad-Adenauer, 2006.

RAMBALDO, Juan Alberto. Cargas probatorias dinámicas: un giro epistemológico. In PEYRANO, Jorge Walter. Cargas probatorias dinámicas. 1. reimp. Santa Fé: RubinzalCulzoni, 2008. p. 25-34.

RANGEL, Rui Manuel de Freitas. O ónus da prova no processo civil. 3. ed. Coimbra: Livraria Almedina, 2006.

RODRIGUES, Marcelo Abelha. Ação civil pública e meio ambiente. Rio de Janeiro: Forense Universitária, 2003. 
Manual de direito processual civil. 4. ed. São Paulo: Revista dos Tribunais, 2008.

. A distribuição do ônus da prova no anteprojeto do código brasileiro de processos coletivos. In GRINOVER, Ada Pellegrini; MENDES, Aluisio Gonçalves de Castro; WATANABE, Kazuo. Direito processual coletivo e o anteprojeto de código brasileiro de processos coletivos. São Paulo: Revista dos Tribunais, 2007. p. 244-253

ROSENBERG, Leo. La carga de la prueba. 2. ed. Buenos Aires: B de F Ltda., 2002.

. Tratado de derecho procesal civil. Tradución Angela Romera Vera. Buenos Aires: EJEA, 1955. v. 2. 3 v.

RUFFINI, Giuseppe. "Argomenti di prova" e "fondamento della decisione" del giudice civile. In Studi di diritto processuale civile in onore di Giuseppe Tarzia. Milano: Giuffrè, 2005. v. 1. p. 887-916.

SANTOS, Moacyr Amaral. Primeiras linhas de direito processual civil. 14. ed. São Paulo: Saraiva, 1989-1991. v. 2. 3 v.

Prova judiciária no cível e comercial. 4. ed. São Paulo: Max Limonad, 1970. v. 1.

SATTA, Salvatore; PUNZI, Carmine. Dirittto processuale civile. $12^{\mathrm{a}}$ ed. Padova: CEDAM, 1996.

SCHIAVON, Francesco. L'inversione dell’onere della prova dal diritto civile alla normativa tributaria. Impresa Commerciale Industriale, Roma, ETI, v. 29, p. 873-877, gen. 2007.

SCHÖNKE, Adolfo. Derecho procesal civil. Traducción de la quinta edición alemana. Barcelona: Bosch, 1946.

SCIALOJA, Vittorio. Procedimiento civil romano: ejercicio y defensa de los derechos. Buenos Aires: Ejea, 1954.

SOARES DE FARIA, Sebastião. Principaes theorias relativas ao onus probandi. 1936. 99f. Dissertação (Provimento de Cátedra - Direito Judiciário Civil) - Faculdade de Direito, Universidade de São Paulo, São Paulo, RT, 1936. 
SOARES, Fernando Augusto de Freitas Motta Luso. A responsabilidade processual civil. Coimbra: Livraria Almedina, 1987.

STEIN, Alex. Foundations of evidence law. New York: Oxford University Press, 2005.

STURNER, Rolf; MURRAY, Peter L. German civil justice. USA: Carolina Academic Press, 2004.

SURGIK, Aloísio. Lineamentos do processo civil romano. Curitiba: Edições Livro é Cultura, 1990.

TAPPER, Colin. Cross and tapper on evidence. $10^{\text {th }}$ ed. London: Lexis Nexis, 2004.

TARUFFO, Michele. La prova dei fatti giuridici: nozioni generali. Milano: Giuffrè, 1992.

; BESSONE, Mario; SILVESTRI, Elisabetta. I metodi della giustizia civile. Padova: CEDAM, 2000.

; COMOGLIO, Luigi Paolo; FERRI, Corrado. Lezioni sul processo civile. Bologna:

Il Mulino, 1995. . Studi sulla rilevanza della prova. Padova: CEDAM, 1970.

. La semplici verità: il giudice e la costruzione dei fatti. Roma: Laterza, 2009.

Modelli di prova e di procedimento probatorio. Rivista di Diritto Processuale, Padova, CEDAM, v. 45, série 2, p. 420-448, anno 1990.

. Rethinking the standards of proof. American journal of comparative law, Padova, CEDAM, v. 51, p. 659-678, 2003.

Presunzioni, inversione, prova del fatto. Rivista Trimestrale di Diritto e Procedura Civile, Milano, Giuffrè, anno 46, n. 3, p. 733-756, settembre 1992. 
dell associazione fra gli studiosi del processo civile. Milano: Giuffrè, 2007. p. 53-90.

TARZIA, Giuseppe. Problemi del processo civile di cognizione. Padova: CEDAM, 1989.

THEODORO JÚNIOR, Humberto. Curso de direito processual civil. 44. ed. 2. tir. Rio de Janeiro: Forense, 2006. v. 1.

Abuso de direito processual no ordenamento jurídico brasileiro. In Abuso dos direitos processuais. BARBOSA MOREIRA, José Carlos. (coord.). Rio de Janeiro: Forense, 2000. p. 93-129.

TROCKER, Nicolò. Processo civile e costituzione: problemi di diritto tedesco e italiano. Milano: Giuffrè, 1974.

; VICENZO, Varano. The reforms of civil procedure in comparative perspective.

Torino: G. Giappichelli, 2005.

. Il contenzioso transnazionale e il diritto delle prove. Rivista Trimestrale di Diritto

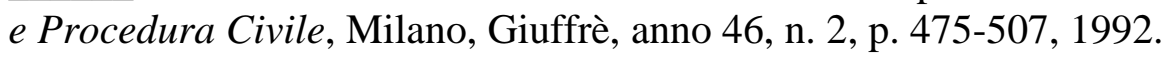

TWINING, William; STEIN, Alex. Evidence and proof. New York: New York University Press, 1992.

TUCCI, José Rogério Cruz e. Garantias constitucionais do processo civil. São Paulo: Revista dos Tribunais, 1999.

2004 .

Precedente judicial como fonte do direito. São Paulo: Revista dos Tribunais,

Lineamentos da nova reforma do CPC. 2. ed. rev., atual. e ampl. São Paulo:

Revista dos Tribunais, 2002.

TUCCI, Rogério Lauria; TUCCI, José Rogério Cruz e. Constituição de 1988 e processo: regramentos e garantias constitucionais do processo. São Paulo: Saraiva, 1989.

; AZEVEDO, Luiz Carlos. Lições de história do processo civil romano. São Paulo: Revista dos Tribunais, 2001. 
Tribunais, 2009 .

. Lições de história do processo civil lusitano. São Paulo: Revista dos

VALLEBONA, Antonio. L`inversione dell onere della prova nel diritto del lavoro. Rivista Trimestrale di Diritto e Procedura Civile, Milano, Giuffrè, ano 46, n. 3, p. 809-834, settembre 1992.

VERDE, Giovanni. L' onere della prova nel processo civile. Pubblicazioni della Scuola di perfezionamento in diritto civile dell'Università di Camerino. Nápoli: Jovene, 1974.

Prove nuove. In CONVEGNO NAZIONALE, 25ㅇ, 2005, Cagliari. Le prove nel processo civile: quaderni dell associazione fra gli studiosi del processo civile. Milano: Giuffrè, 2007. p. 01-27.

Prova: b) teoria generale e diritto processuale civile. In Enciclopedia del diritto. Milano: Giuffrè, 1958. v. 37.

. Considerazioni sulla regola di giudizio fondata sull'onere della prova. Rivista di Diritto Processuale, Milano, v. 27, n. 2, p. 438-463, luglio-sett. 1972.

La prova nel processo civile: profilo di teoria generale. Rivista di Diritto Processuale, Padova, Cedam, v. 53, série 2, p. 2-25, genn.-mar. 1998.

Le presunzioni giurisprudenziali (introduzione a un rinnovato studio sull onere della prova). Il Foro Italiano, Roma, v. 94, parte 5, p. 178-192, anno 1971.

. L'inversione degli oneri probatori nel processo. Rivista Trimestrale di Diritto e Procedura Civile, Milano, Giuffrè, ano 46, n. 3, p. 715-731, settembre 1992.

Profili del processo civile: parte generale. Napoli: Jovene, 1978.

VÉSCOVI, Enrique. Teoria general del proceso. 2. ed. Santa Fé de Bogotá - Colômbia: Editorial Temis S.A., 1999.

VIGORITI, Vincenzo. Sul metodo comparativo. In YARSHELL, Luiz Flávio; MORAES, Maurício Zanoide de. (coord.). Estudos em homenagem à professora Ada Pellegrini

Grinover. São Paulo: DPJ Editora, 2005. p. 861-865. 
VINCENZO, Zeno-Zencovich. L`onere della prova dei fatti negativi in una recente sentenza della corte suprema americana. Il Foro Italiano, Roma, v. 110, parte 4, p. 27-40, anno 1987.

WALTER, Gerhard. Libre apreciación de la prueba: investigación acerca del significado, las condiciones y límites del libre convencimiento judicial. Bogotá, Colômbia: Temis Librería, 1985.

WEIGMANN, Roberto. L`inversione dell’onere della prova nel diritto commerciale. Rivista Trimestrale di Diritto e Procedura Civile, Milano, Giuffrè, ano 46, n. 3, p. 797808, settembre 1992.

YARSHELL, Flávio Luiz. Antecipação da prova sem o requisito da urgência e direito autônomo à prova. São Paulo: Malheiros, 2009.

ZANETI JÚNIOR, Hermes. Direito probatório, lógica jurídica e processo: a racionalidade prática procedimental e o retorno ao juízo. In NEVES, Daniel Amorim Assumpção. Provas: aspectos atuais do direito probatório. São Paulo: Método, 2009. p. 179-227. 